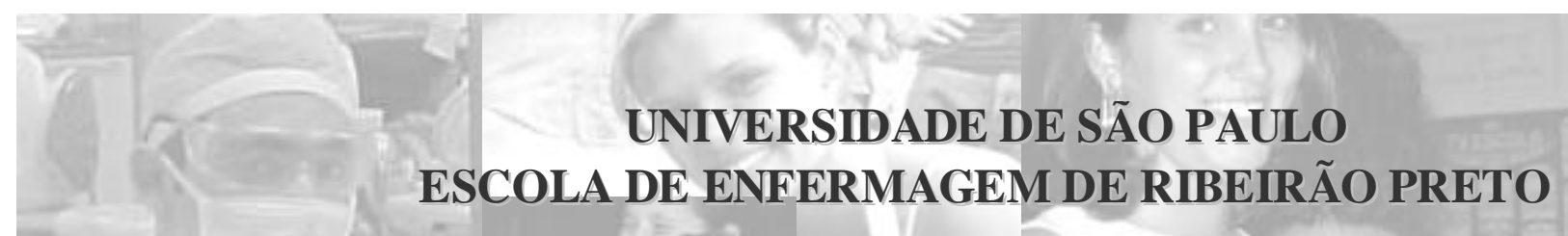

\title{
A SAÚDE BUCAL COLETIVA NA VISÃO DO ESTUDANTE DE ODONTOLOGIA: ESTUDO DE UMA EXPERIÊNCIA
}

\section{Liliane Parreira Tannús Gontijo}

Dissertação apresentada à Escola de Enfermagem de Ribeirão Preto da Universidade de São Paulo, para concorrer ao Título de Mestre, pelo curso de Pós Graduação de Enfermagem em Saúde Pública - Linha de Pesquisa: Práticas, saberes e políticas de saúde.

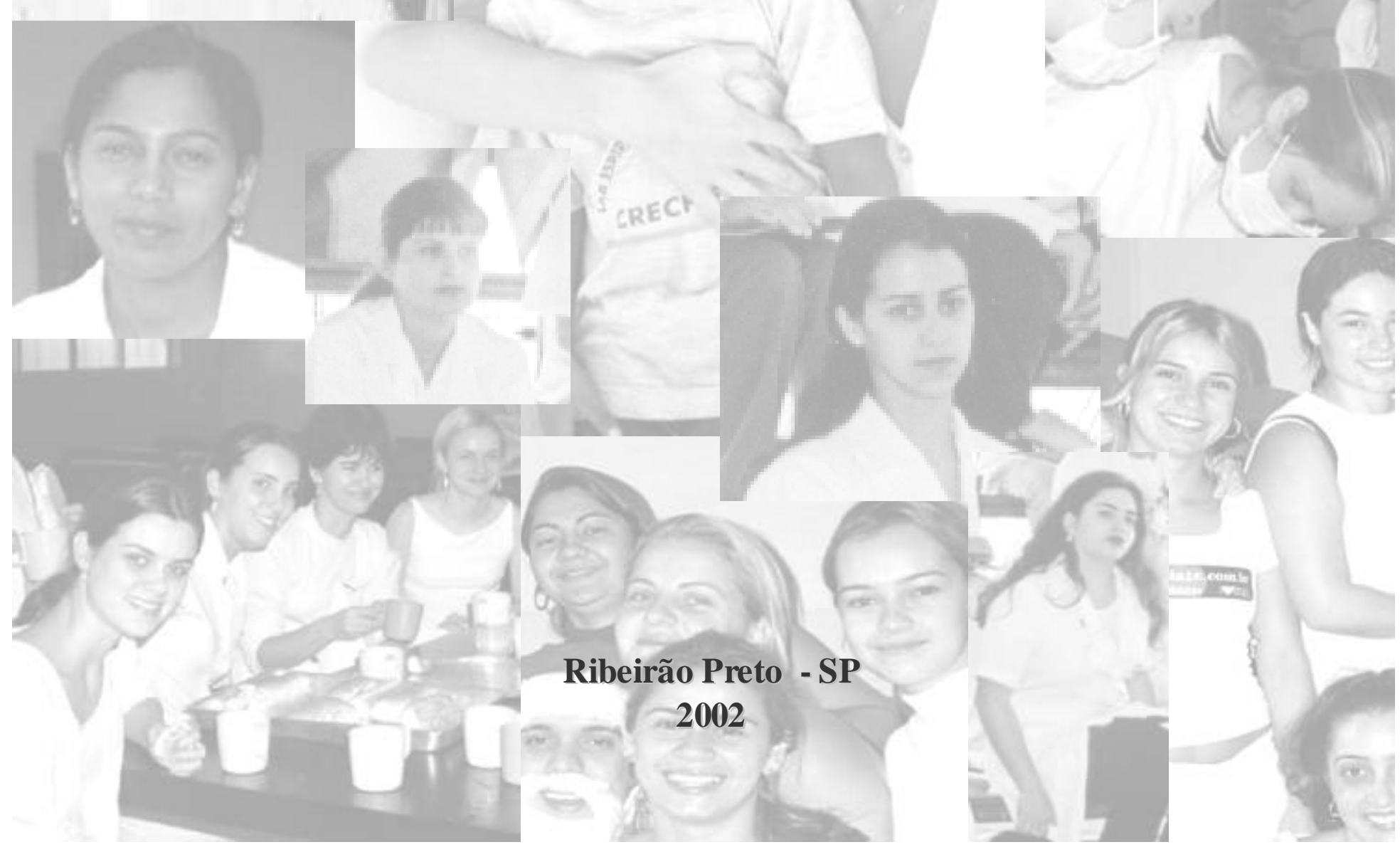




\author{
UNIVERSIDADE DE SÃO PAULO \\ ESCOLA DE ENFERMAGEM DE RIBEIRÃO PRETO
}

A SAÚDE BUCAL COLETIVA

NA VISÃO DO ESTUDANTE DE ODONTOLOGIA:

ESTUDO DE UMA EXPERIÊNCIA

\title{
Liliane Parreira Tannús Gontijo
}

Dissertação apresentada à Escola de Enfermagem de Ribeirão Preto da Universidade de São Paulo, para concorrer ao Título de Mestre, pelo curso de Pós Graduação de Enfermagem em Saúde Pública - Linha de Pesquisa: Práticas, saberes e políticas de saúde.

RIBEIRÃO PRETO 


\section{A SAÚDE BUCAL COLETIVA}

\section{NA VISÃO DO ESTUDANTE DE ODONTOLOGIA:}

ESTUDO DE UMA EXPERIÊNCIA

\section{Liliane Parreira Tannús Gontijo}

Dissertação apresentada à Escola de Enfermagem de Ribeirão Preto da Universidade de São Paulo, para concorrer ao Título de Mestre, pelo curso de Pós Graduação de Enfermagem em Saúde Pública - Linha de Pesquisa: Práticas, saberes e políticas de saúde.

Orientadora: Maria Cecília Puntel de Almeida

RIBEIRÃO PRETO 


\section{FICHA CATALOGRÁFICA}

Tannús - Gontijo, Liliane Parreira

A saúde bucal coletiva na visão do estudante de odontologia: estudo de uma experiência. Ribeirão Preto, 2002.

219 p. : il. ; $30 \mathrm{~cm}$

Dissertação de Mestrado, apresentada à Escola de Enfermagem de Ribeirão Preto/USP - Área de concentração: Saúde Pública.

Orientadora: Almeida, Maria Cecília Puntel.

1. Saúde bucal coletiva. 2. Ensino odontológico.

3. Saúde da família. 
Data da Defesa: 20/12/2002

Banca Examinadora

Prof ${ }^{a}$. Dra. Maria Cecília Puntel de Almeida

Julgamento: Assinatura:

Prof. Dr. Vitor Gomes Pinto

Julgamento: Assinatura:

Prof $^{a}$. Dra. Silvana Martins Mishima

Julgamento: Assinatura:

Prof. Dr. Manoel Américo Barros Filho Julgamento: Assinatura:

Prof ${ }^{\text {a }}$ Dra. Maria José Bistafa

Julgamento: Assinatura: 
Saber por saber: isso é inumano... A tarefa do professor é a mesma da cozinheira: antes de dar faca e queijo ao aluno, provocar a fome... Se ele tiver fome, mesmo que não haja queijo, ele acabará por fazer uma maquineta de roubá-los. Toda tese acadêmica deveria ser isso: uma maquineta de roubar o objeto que se deseja...

(Rubem Alves, 2002) 


\section{DEDICATÓRIA}

Ao Eduardo, meu companheiro, pelo amor dado de graça, que tem sido o grande amparo e incentivo durante a caminhada...

"Amor é dado de graça, é semeado no vento, na cachoeira, no eclipse..."

(Drumond) 


\section{AGRADECIMENTOS ESPECIAIS}

- Agradeço a Deus por ter me acompanhado e protegido nestes dois anos de árdua caminhada, parafraseando Renato Russo, na voz da saudosa Cássia Eller, minha companheira de viagem no trajeto Uberlândia/Ribeirão Preto: “Mudaram as estações. Nada mudou. Mas eu sei que alguma coisa aconteceu. Tá tudo assim, tão diferente. Se lembra quando a gente chegou um dia a acreditar, que tudo era para sempre. Sem saber, que o para sempre, sempre acaba. Mas nada vai conseguir mudar o que ficou... Mesmo com tantos motivos para deixar tudo como está. Nem desistir, nem tentar. Agora, tanto faz. Estou indo de volta para casa."

- À amiga e orientadora, Prof ${ }^{a}$ Maria Cecília Puntel de Almeida, pelo permanente incentivo e apoio e o seu jeito sutil, elegante e perspicaz de sugerir.

- Ao meu companheiro, Eduardo Savastano Gontijo, pelo amor e apoio incondicional.

- Aos meus pais, Amilson Guimarães Tannús e Delminda Luzia Vilela Parreira, pelos valores e responsabilidade com que me criaram e a presença nos momentos difíceis.

- Às minhas filhas, Ana Carolina Tannús Gontijo e Mariana Tannús Gontijo, por aceitarem as minhas ausências e se esforçarem por compreendê-las. 


\section{AGRADECIMENTOS}

- Aos usuários do serviço público de saúde, especialmente as famílias e as crianças que atendemos, através do Projeto Saúde Bucal Coletiva Saúde e Cidadania, a minha gratidão a vocês, que através dos anos têm nos concedido a possibilidade de compartilhar suas esperanças.

- Aos meus alunos, que tem sido a grande razão e incentivo de meu aperfeiçoamento técnico e pela contribuição com as entrevistas.

- Ao amigo e coordenador do Curso de Odontologia da UNIT, Dr. Odorico Coelho da Costa Neto, que viabilizou, encorajou e apoiou o Projeto Saúde Bucal Coletiva - Saúde e Cidadania, em todas as suas fases.

- Ao amigo Flávio A. de Andrade Goulart por mais uma vez iluminar o meu trilhar na saúde coletiva.

- À amiga Rúbia Pereira Barra, pelo compartilhar das inquietações ideológicas, solidária nos momentos difíceis e sempre juntas nas realizações profissionais. Esta dissertação é uma porção de você.

- À amiga Leila Regina Scalia Gomide, companheira dos conflitos acadêmicos, suas leituras incansáveis, sugestões concernentes e o seu permanente incentivo foram fundamentais na elaboração desta dissertação, que é uma parte de você.

- À amiga Cristina Angélica Gomes, substituindo-me na docência, por várias vezes durante este ano, possibilitando o meu vôo nesta dissertação e por compartilharmos as realizações do Projeto. Esta dissertação também é uma parte de você. 
- À amiga Maria Margaret de Vasconcellos Lemos, pela revisão da forma da dissertação, as sugestões pertinentes e o grande apoio no cumprimento das diretrizes de dissertação à USP.

- Ao amigo Dr. Paulo Roberto Salomão, Ex-Secretário Municipal de Saúde de Uberlândia, pelo apoio incondicional a minha vida profissional e o incentivo ao Projeto Saúde Bucal Coletiva - Saúde e Cidadania, através da parceria desenvolvida entre os serviços e ações da Secretaria de Saúde com a UNIT, durante sua gestão.

- Às amigas e companheiras de viagem, Marisa e Simone, pelas horas agradáveis que passamos juntas e pela contribuição com as entrevistas.

- À amiga Cristiane Gramani Say, estagiária da Prof ${ }^{a}$ Maria Cecília Puntel de Almeida, pela gentileza, atenção e prontidão frente às minhas várias solicitações, durante o mestrado, inclusive aos finais de semana.

- Às amigas, Dorca Luiza de Freitas Salomão e Marinalva Perfeito Machado, que me apoiaram e incentivaram ao retorno das minhas atividades clínicas e restauradoras, no Centro de Saúde Escola Jaraguá.

- Ao Dr. Vitor Gomes Pinto, meu guru da saúde bucal coletiva, pelo aceite ao meu pedido para participar da Banca Examinadora da Dissertação e a positividade e incentivo proporcionado pelo seu parecer sobre este trabalho.

- À Prof ${ }^{\mathrm{a}}$ Silvana Martins Mishima, docente da EERP, pelas sugestões apropriadas, pelo cuidado e conveniência de suas correções, extremamente apropriadas durante o processo da qualificação e da próforma da dissertação. 
- Á Prof ${ }^{\text {a }}$ Maria José Bistafa, docente da EERP, pelo encorajamento e incentivo no momento da qualificação.

- Ao Dr. Vicente Carlos da Silva e a Dra. Evonete Maria de Oliveira Marra, Diretor do Hospital Odontológico e Docente do Departamento de Odontologia Social e Preventiva da UFU, que me acolheram em um momento difícil de minha vida profissional.

- À colega, Renata Prata Cunha Bernardes, pela contribuição nas entrevistas.

- À diretora da Escola do Bairro Jardim das Palmeiras, Solange Monteiro de Lima e Santos, pela sua garra e determinação com que acolhe o Projeto Saúde Bucal Coletiva - Saúde e Cidadania e coordena a referida Escola.

- Á EERP, Escola de Enfermagem de Ribeirão Preto da Universidade de São Paulo, por ter me acolhido e compartilhado comigo o saber aqui produzido.

- A todos que direta ou indiretamente, colaboraram na execução deste trabalho. 


\section{SUMÁRIO}

página

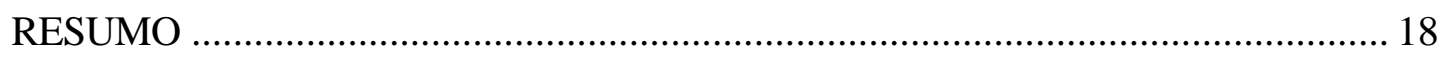

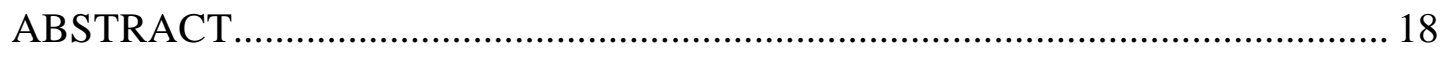

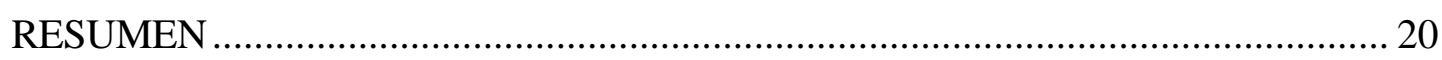

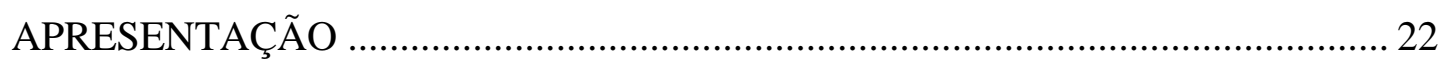

1 INTRODUÇÃ

1.1 Definição e delimitação do problema em estudo ..................................... 37

1.2 O Curso de Odontologia, o Centro Universitário do Triângulo, a

Secretaria Municipal de Saúde e o Município de Uberlândia ........................... 42

1.3 O Estudo de caso: o projeto saúde bucal coletiva - saúde e

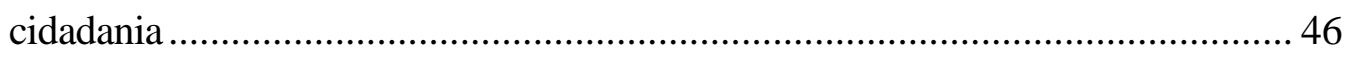

1.3.1 Proposta metodológica e organizacional..................................... 50

1.3.2 Objetivos Educacionais e Etapas do Projeto................................ 52

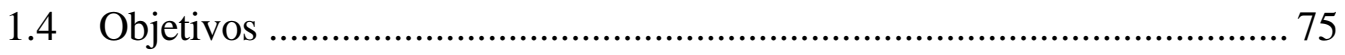

1.4 .1 Objetivo Geral.................................................................. 75

1.4.2 Objetivos Específicos.............................................................. 75

2 A CONSTRUÇÃO DO REFERENCIAL TEÓRICO...................................... 77

Apontando para a necessidade de repensar o processo de ensino-

aprendizagem na odontologia e as concepções que embasam a saúde

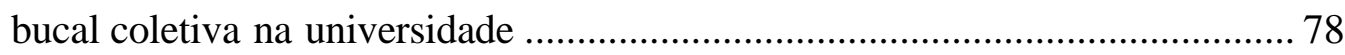

2.1 O Suporte Teórico para olhar o Projeto Saúde Bucal Coletiva................ 82

2.2 O Ideário UNI - Uma Nova Iniciativa na Educação dos

Profissionais de Saúde e o curso de graduação em odontologia -

Similaridades com o Projeto Saúde Bucal Coletiva................................. 92

3 O PERCURSO METODOLÓGICO …............................................................ 105 


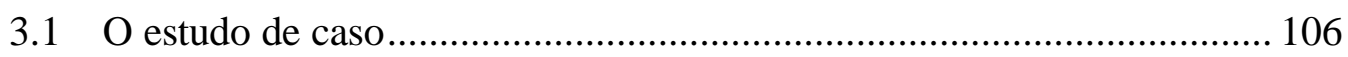

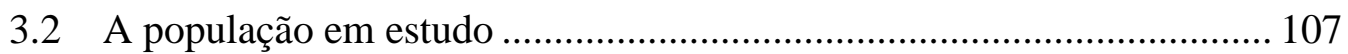

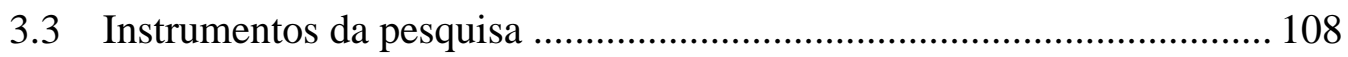

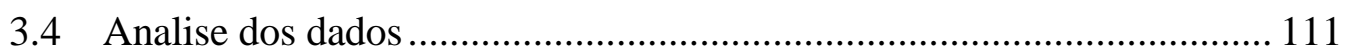

3.5 As questões éticas da pesquisa........................................................... 112

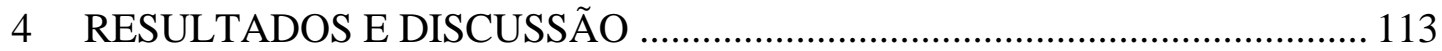

4.1 Perfil do estudante do curso de odontologia da UNIT, por ocasião do ingresso na universidade. ................................................................... 114

4.2 Sobre as contribuições do projeto de saúde bucal coletiva, para a formação do estudante de odontologia .................................................... 122

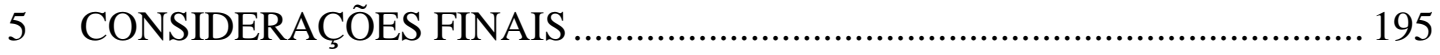

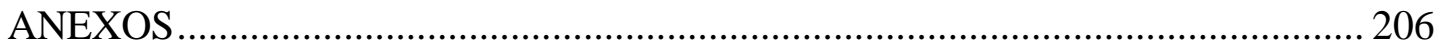

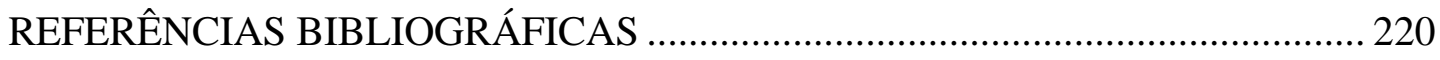

\section{LISTA DE FIGURAS}

$\begin{array}{lll}\text { Figura } 1 & \text { Alunos realizando o cadastramento das famílias. } & 59\end{array}$

Figura 2 Estudantes de odontologia em atividades de interação com pais de alunos da E. E. Jardim das Palmeiras. 64

Figura 3 Realização das atividades junto aos membros da família. 66

Figura 4 Atividades preventivas realizadas na Creche Lar Alfredo Júlio.

68

$\begin{array}{lll}\text { Figura } 5 & \text { Atividades clínico-restauradoras. } & 74\end{array}$

Figura 6 Contribuição do Projeto Saúde Bucal Coletiva para a formação do estudante de odontologia, conforme as etapas do segundo ao oitavo período, Uberlândia, 2002.

Figura 7 Respostas dos estudantes do curso de odontologia, segundo suas pretensões em atuar profissionalmente em abordagens de alcance coletivo em saúde bucal.

Uberlândia, 2002. 


\section{LISTA DE TABELAS}

Tabela 1 Participação do projeto saúde e cidadania, segundo o semestre e o período do curso, nos anos de 1999 a 2002, UNIT, Uberlândia, MG, 2002

Tabela 2 Classes de risco de cárie dentária e critérios de agrupamento, segundo a situação individual

Tabela 3 Principais elementos estruturais da odontologia cientificista e da odontologia integral

Tabela 4 Possíveis razões para o declínio da cárie nos últimos trinta anos, em países industrializados ricos

Tabela 5 Relação de alunos matriculados e participantes do projeto, no período de março de 1999 a março de 2002, no Centro Universitário do Triângulo - UNIT, em Uberlândia, Minas Gerais

Tabela 6 Relação da mão-de-obra feminina na força de trabalho em saúde, segundo algumas categorias profissionais. Brasil, 1970-1980

Tabela 7 Distribuição dos estudantes do sétimo e oitavo períodos do Curso de Odontologia, segundo a participação no questionário aplicado. Uberlândia, 2002

Tabela 8 Distribuição dos estudantes do Curso de Odontologia, que responderam aos questionários, segundo o sexo.

Uberlândia, 2002

Tabela 9 Distribuição dos estudantes, do sétimo e oitavo períodos, do Curso de Odontologia, que responderam aos questionários, segundo a faixa etária. Uberlândia, 2002

Tabela 10 Motivos para a escolha da carreira odontológica, pelos estudantes do curso de odontologia. Uberlândia, 2002

Tabela 11 Motivos para escolha da carreira odontológica, segundo classificação em ordem decrescente de importância, realizada pelos estudantes das universidades de Alfenas (1996) e Uberlândia (2002)

Tabela 12 Justificativas da contribuição da primeira etapa do Projeto Saúde Bucal Coletiva, na formação do estudante de odontologia, segundo classificação em ordem decrescente de importância. Uberlândia, 2002

Tabela 13 Justificativa da contribuição da segunda etapa do Projeto Saúde Bucal Coletiva, na formação do estudante de odontologia, segundo classificação em ordem decrescente de importância. Uberlândia, 2002

Tabela 14 Justificativas da não contribuição da terceira etapa do Projeto Saúde Bucal Coletiva, na formação do estudante de odontologia, segundo classificação em ordem decrescente de importância. Uberlândia, 2002 
Tabela 15 Justificativa da contribuição da terceira etapa do Projeto Saúde Bucal Coletiva, na formação do estudante de odontologia, segundo classificação em ordem decrescente de importância. Uberlândia, 2002

Tabela 16 Justific ativa da contribuição da quarta etapa do Projeto Saúde Bucal Coletiva, na formação do estudante de odontologia, segundo classificação em ordem decrescente de importância. Uberlândia, 2002

Tabela 17 Justificativa contribuição da quinta etapa do Projeto Saúde Bucal Coletiva, na formação do estudante de odontologia, segundo classificação em ordem decrescente de importância. Uberlândia, 2002

Tabela 18 Justificativas dos estudantes de odontologia, segundo a opção em atuar em abordagens coletivas em saúde bucal, segundo ordem decrescente de freqüência. Uberlândia/ 2002

Tabela 19 Especialidades Odontológicas, segundo a preferência para atuação profissional do estudante de odontologia. Uberlândia, 2002

Tabela 20 Atividades de Ensino desenvolvidas pelo Projeto Saúde Bucal Coletiva, segundo sua importância, UNIT, Uberlândia, 2002

Tabela 21 Expectativas do estudante de odontologia frente ao Projeto Saúde Bucal Coletiva. Uberlândia, 2002

Tabela 22 Justificativas do estudante de odontologia para participação do Projeto Saúde Bucal Coletiva. Uberlândia, 2002

Tabela 23 Noções do estudante de odontologia sobre o Programa de Saúde da Família. Uberlândia, 2002

Tabela 24 Papel do odontólogo no Sistema Único de Saúde brasileiro, segundo o estudante de odontologia. Uberlândia, 2002

Tabela 25 Visão do estudante de odontologia sobre as crianças que atendeu durante o Projeto Saúde Bucal Coletiva. Uberlândia, 2002

Tabela 26 Visão do estudante de odontologia sobre as famílias que atendeu durante o Projeto Saúde Bucal Coletiva. Uberlândia, 2002

Tabela 27 Condições de saúde bucal das crianças e das famílias atendidas, durante o Projeto Saúde Bucal Coletiva, segundo a percepção do estudante de odontologia. Uberlândia, 2002 


\title{
LISTA DE ABREVIATURAS
}

\author{
ABO Associação Brasileira de Odontologia \\ CEC Controle Epidemiológico da Cárie \\ CFO Conselho Federal de Odontologia
}

CLATES Centro Latino-Americano de Tecnologia Educacional em Saúde

CNE Conselho Nacional de Educação

CPOD Dentes Cariados, Perdidos e Obturados

CRO Conselho Regional de Odontologia

ESF Estratégia de Saúde da Família

EERP Escola de Enfermagem de Ribeirão Preto

FAEPU Fundação de Assistência ao Ensino e a Pesquisa em Uberlândia

FIT Faculdades Integradas do Triângulo

IBGE Instituto Brasileiro de Geografia e Estatística

IDA Integração Docente Assistencial

IDH Índice de Desenvolvimento Humano

MEC Ministério de Educação e Cultura

NOAS Norma Operacional da Assistência à Saúde

PNAD Pesquisa Nacional por Amostra de Domicílio

PSF Programa de Saúde da Família

SESU Secretaria de Ensino Superior 
SMS Secretária Municipal de Saúde

SUS Sistema Único de Saúde

UAI Unidade de Atendimento Integrado

UFU Universidade Federal de Uberlândia

UNESP Universidade do Estado de São Paulo

UNI Uma Nova Iniciativa na Formação de Profissionais de Saúde

UNIT Centro Universitário do Triângulo 
RESUMO 
Tannús Gontijo, L. P. A saúde bucal coletiva na visão do estudante de odontologia: estudo de uma experiência. Ribeirão Preto, 2002. 229f. Dissertação (Mestrado) - Escola de Enfermagem de Ribeirão Preto, Universidade de São Paulo.

Estudo descritivo sobre a contribuição do Projeto Saúde Bucal Coletiva na formação do estudante do Curso de Odontologia, do Centro Universitário do Triângulo - UNIT, em Uberlândia, Minas Gerais, para atuação em saúde bucal de alcance coletivo, sob a perspectiva dos princípios do Sistema Único de Saúde, da promoção em saúde e da atenção em saúde da família.

O Projeto fundamenta-se no fato de que saúde e doença são determinados por fatores sociais, econômicos e culturais e também influenciados por serviços odontológicos e por medidas efetivas de saúde coletiva, sendo essencial a implementação de políticas públicas saudáveis, tanto em nível local como as macroestruturais. Quanto às concepções da saúde bucal coletiva no ensino da odontologia baseia-se em três autores consagrados da literatura nacional.

Através da aplicação de dois questionários, estuda o perfil social do aluno e a abrangência do Projeto, na visão do estudante de odontologia, possibilitando a caracterização do mesmo, em seus aspectos pedagógicos e operacionais, suas potencialidades e limitações.

Os resultados demonstraram que o Projeto insere o estudante de odontologia, oriundos, em sua maioria, de classes sociais de maior poder aquisitivo, em uma realidade econômica, social e cultural muito diferente da que vivenciam, possibilitando o contato com uma vertente do mercado de trabalho, sensibilizando-os para esta realidade estranha. Constitui-se nos primeiros contatos efetivos e práticos com aspectos da saúde bucal coletiva e a sociologia.

Contudo, mesmo o Projeto buscando demonstrar o avanço da epidemiologia e da cariologia e novas tendências no agir do processo saúde e doença bucal, definindo um programa de prevenção que se propõe a redimensionar o modelo odontológico tradicional, não seduz totalmente o estudante como o faz a atenção clínica curativa, mas cria um espaço no processo de ensino aprendizagem de reflexão crítica sobre a odontologia e permite a atuação dos estudantes em saúde bucal coletiva com populações discriminadas e carentes.

UNITERMOS: Saúde bucal coletiva, ensino odontológico, saúde da família. 
Tannús Gontijo, L. P. The Collective buccal health from the point of view student of dentistry: research study. Ribeirão Preto, 2002. 229f. Post-Graduation Essay (Master) - Ribeirão Preto Nursing School, S. Paulo University.

Descriptive study of the way in which the Collective Buccal Health Project contributes in training the student taking the (Dentistry Course) at UNIT (Centro Universitário do Triângulo), in Uberlândia, M.G. Brazil, to work in buccal health at a collective level, guided by the principle of the One Way Health System, for health promoting itself and attention to family.

The Project is based on the fact that health and sickness are caused by social, economic and cultural factors; and also influenced by dental services and by effective collective health measures. The implantation of healthy public polices being essencial, in both local and macrostructural levels. As to collective buccal health conceptions taught in dentistry, these are based on three outstanding authors in Brazilian literature.

It takes into consideration the scope of the Project as seen by dental student, using two questionnaires permitting the caracterization of the Project in its pedagogic and operational aspects, its potencial and limitations delineating the social profile of the student.

The results demonstrated that the Projet includes the student, who, in most cases, comes from wealthier social classes, in an economical, social and cultural reality very different from that to which they were accustomed- permitting contact with a section of the work force. Making them more aware of this strange reality. It is achieved in the first effective and practical contacts with aspects of collective buccal health and sociology.

Even though the Project tries to demonstrate the advance of epidemiology and treatment of caries and new tendencies for acting in the health and buccal sicknesses process, specifying a prevention program being able to propose changes in the traditional odontologic model, it does not stimulate the student, like private clinical practice.

Notwithstanding, it creates space in collective buccal health among discriminated and needy populations.

UNITERMOS: collective buccal health, odontological teaching, family health. 
Tannús Gontijo, L. P. La salud bucal colectiva en la visión del estudiante de odontología: estudio de una experiencia . Ribeirão Preto 2002 229f. Disertación (Master) - Escuela de Enfermería de Ribeirão Preto. Universidad de São Paulo.

Estudio descriptivo de la contribución del Proyecto Salud Bucal Colectiva en la formación del estudiante del Curso de Odontología, del Centro Universitario del Triángulo-UNIT , en Uberlândia, Minas Gerais, para la actuación en salud bucal de alcance colectivo, bajo la perspectiva de los principios del Sistema Único de Salud, de la promoción en salud y de la atención a la salud de la familia.

El Proyecto se fundamenta en el hecho de que la salud y las enfermedades son determinadas por factores sociales, económicos, culturales y también influenciados por servicios odontológicos y por medidas efectivas de salud colectiva, siendo esencial la implementación de políticas públicas saludables tanto a nivel local como las macroestruturales. Las concepciones de la salud bucal colectiva en la enseñanza de la odontología se basa en tres autores consagrados de la literatura nacional.

Estudia la abrangencia del proyecto a través de la visión del estudiante de odontología, aplicando dos cuestionarios, posibilitando la caracterización del Proyecto en sus aspectos pedagógicos, operacionales, sus potencialidades y limitaciones trazando el perfil social del alumno.

Los resultados demuestran que el Proyecto introduce al estudiante de odontología, oriundo en su mayoría de clases sociales de mayor poder adquisitivo, en una realidad económica, social y cultural muy diferente de la que viven, posibilitando el contacto con una vertiente del mercado de trabajo, sensibilizándose para esta extraña realidad.

Se constituye así en los primeros efectivos y prácticos la relación entre los efectos de la salud bucal colectiva y la sociología.

Mismo el Proyecto buscando demostrar el avance de la epidemiología y de la cariología y nuevas tendencias en el proceso salud y enfermedades bucales definiendo un programa de prevención que se propone redimensionar el modelo odontológico tradicional no seduce al estudiante como lo hace la atención clínica curativa.

Pero crea un espacio en el proceso de enseñanza aprendizaje de reflección crítica, sobre la odontología y permite la actuación de los estudiantes en salud bucal colectiva con poblaciones discriminadas y carentes.

UNITERNOS: Salud bucal colectiva, enseñanza odontológica, salud de la familia. 


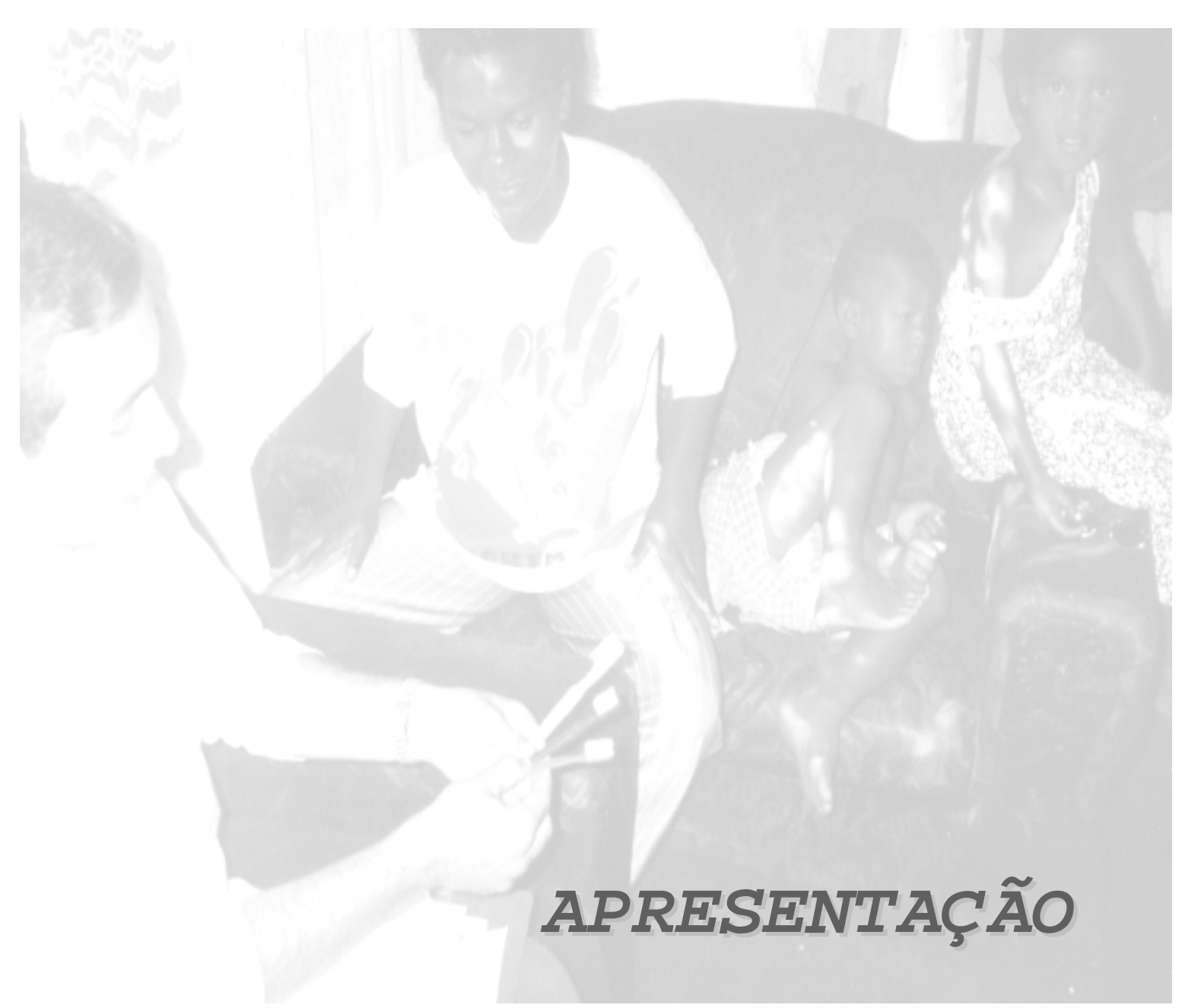


Nos interessamos pelas mazelas da saúde bucal coletiva porque acreditamos que os caminhos a seguir pela educação e a prática odontológica no Brasil, possibilitando acesso à população aos seus serviços de forma mais igualitária, existem e já estão apontados, independente da conjuntura política e econômica do país. Não somos "otimistas delirantes" e sim realistas cientes das limitações presentes. Concebemos que saúde e doença são determinados por fatores sociais, econômicos e culturais e também influenciados por serviços odontológicos ou, mesmo por medidas efetivas de saúde coletiva, sendo fundamental a implementação de políticas públicas, tanto em nível local como as macroestruturais.

Considerando que os profissionais da área de saúde coletiva ou os interessados na mudança do quadro desalentador da morbidade bucal no país, neste século que se inicia, defrontam-se, geralmente, com três caminhos: a ação - às vezes limitada; a acomodação - no sentido do comportamento que tende a evitar ou reduzir conflitos ou a omissão - o imobilismo e a negação frente às questões sociais, entendemos que o simples agir em direção a obtenção de alternativas para educação odontológica, que privilegie o caráter social da profissão, a promoção e a garantia do direito a saúde deve ser valorizado, como a primeira etapa a ser percorrida.

Assim, o presente trabalho apresenta uma opção pela ação e o trilhar de um caminho na busca de uma odontologia, conforme concebe Montez Campuzano (1989) que “A odontologia é em si, uma ciência de caráter social. Não poderia, portanto, ser concebida como uma disciplina a serviço exclusivo de uns poucos".

Não trazemos nada de inovador ou vanguardista, apenas refletimos sobre a aplicação do que já foi dito, executado e conceituado por vários autores nacionais e internacionais. Acrescentamos, com certeza, uma experiência simples de preparação 
do estudante de odontologia, onde se percebe claramente que determinação, sensibilização e envolvimento, com as responsabilidades sociais da profissão, foram pré - condição para os resultados obtidos, nesta tentativa de trilhar melhores caminhos para a educação odontológica no país.

Percebemos que aquele que é excluído, que, sem voz, não tem alimento, não tem moradia, também não tem dentes, erá dificuldades em conseguir um bom emprego e dificilmente será feliz. A felicidade também passa por um sorriso saudável. Assim, concordamos com Spinelli (1998), quando coloca que: quem se responsabiliza pela educação odontológica no nosso país precisa se questionar sobre "para quem" estamos desenvolvendo a odontologia, "que Escola" estamos construindo e, por fim, qual é o profissional de odontologia necessário para o século que se inicia?

De fato, pensamos como a referida autora;

"A pergunta "para quem?" é de ordem estritamente social, procura saber em benefício de que classes e forças sociais estamos elaborando o conhecimento da ciência odontológica. Tal definição política de primeira instância irá determinar "o que" e "como". Essa tarefa é coletiva e vai além do pedagogismo reformista, em busca de uma pedagogia do necessitado..."(SPINELLI, 1998, p.212)

Analisando o perfil dos alunos formados em Odontologia no Estado de São Paulo, em 1992, levou Freitas e Nakayama (1995) a concluir que o perfil pretendido pelo currículo mínimo, implantado a partir de 1982, não foi alcançado: a maioria dos estudantes de Odontologia, oriundos de classes sociais de maior poder aquisitivo, demonstra pouca ou nenhuma preocupação com as responsabilidades sociais da profissão e revela forte tendência à especialização.

Para muitos estudantes, conforme menciona Venturelli (1999), o objetivo de estudar medicina, além de ser mais economicista e mercenário, foi se transformando 
em uma obrigatoriedade formar-se em uma especialidade, que em grande medida não vão encontrar trabalho e quando encontram tendem a aumentar os custos na saúde cada vez mais. Esta crise se estende, na mesma magnitude, para os estudantes do curso de odontologia, evidenciando que as universidades continuam centradas em si mesmas e sem querer aprender com a realidade.

Para que haja uma transformação dos níveis de saúde bucal da população, será necessário que os profissionais e os responsáveis por sua formação compreendam a estrutura social, as bases da saúde coletiva e a inserção da odontologia neste contexto, além da compreensão das relações sociais e econômicas decorrentes da situação concreta da sociedade.

Em 1988, o texto constitucional consagrou a saúde como produto social e em 1990, com as Leis Orgânicas da Saúde: (Leis 8080 e 8142) foram estabelecidas as bases para a organização e o funcionamento do Sistema Único de Saúde - SUS, o que trouxe a possibilidade de antevermos um sistema que assegurasse acesso universal e equânime às ações e aos serviços necessários para a promoção, prevenção e recuperação da saúde da nossa população e a satisfação desta com os serviços ofertados (BRASIL, [199-?]).

Após quatorze anos de sua promulgação, perpassando da IX a XI Conferências Nacionais de Saúde, mesmo com avanços, convivemos com os grandes dilemas do SUS; segmentação versus universalização, fragmentação versus integralização, a municipalização autárquica versus a municipalização cooperativa, Programa de Saúde da Família (PSF) flexibilizado, de acordo com as especificidades locais versus PSF implantado conforme modelo oficial e dentre outros dilemas 
destaca-se a formação de pessoal voltado para o SUS versus formação voltada para as especialidades lucrativas do mercado de trabalho.

Neste contexto complexo, da política oficial de saúde que busca acesso, se não igualitário pelo menos equânime aos serviços de saúde, observa-se que - "Quase um quinto dos brasileiros nunca foi ao dentista”. O dado considerado "impressionante" pelo Ministério da Saúde está na pesquisa sobre "Acesso e Utilização de Serviços de Saúde”, feita pelo IBGE (Instituto Brasileiro de Geografia e Estatística), junto com o PNAD (Pesquisa Nacional por amostra de domicílios) em 1998, publicada na Folha de São Paulo. O estudo mostra que, se utilizarmos o percentual calculado para toda a população brasileira, chega-se a 29,6 milhões de pessoas $(19,5 \%)$ que nunca tiveram atendimento odontológico. $\mathrm{Na}$ área rural, o percentual é 32\%. "É espantoso. Eu estou abismado”, disse o ministro da Saúde José Serra. $(19,5 \% \ldots 2000)$.

A Folha de São Paulo complementa que "uma em cada 10 crianças pobres do Pará, Acre e Amapá está condenada a ficar desdentada antes de completar 13 anos". (POBRE... 2000).

Estes dados têm, evidentemente, uma relação direta com a população que ganha até um salário mínimo, sendo que o número de pessoas que nunca foram ao dentista é nove vezes maior do que o número de usuários entre as que ganham mais de 20 salários mínimos.

A situação descrita explica-se, embora não se justifique, por vários fatores que perpassam a questão da saúde bucal no Brasil, destacando-se a predominância de um modelo odontológico curativo e clínico restaurador, não utilização dos instrumentos de controle das doenças bucais disponíveis, a maioria dos planos de 
saúde privada não tem cobertura odontológica e a escassa cobertura dos programas odontológicos públicos de caráter coletivo e reduzido acesso aos serviços odontológicos de forma ampla e integral aos usuários do SUS.

Concordamos integralmente com Pinto (2000) ao definir os limites de poder da odontologia, a qual tem em mãos apenas uma parcela dos meios e do poder necessários para manter sob controle as questões que estão em sua área de influência, demarcando a dependência da resolução dos problemas de saúde bucal a vários outros fatores;

"Uma multiplicidade de variáveis extra-odontológicas condiciona a existência ou não das doenças e influi no ritmo e na velocidade em que elas se expandem. O desenvolvimento econômico, a ideologia do Estado, a forma de organização do governo, o nível educacional da população, assim como os padrões de cultura e de tradição popular que regulam a formação de hábitos alimentares e as condutas de higiene pessoal $e$ coletiva, fazem parte íntima do processo saúde-doença”.(PINTO, 2000)

Torna-se importante ressaltar que a maioria da população brasileira encontrase em uma situação de uso dos serviços de saúde, que podemos denominar "SUS dependente”, conforme menciona Renilson (2000): “... somos 160 milhões de brasileiros, sendo que 120 milhões usam única e exclusivamente os serviços do Sistema Único de Saúde”.

Segundo Werner [1989?], a prática odontológica no Brasil já passou a sua fase infantil assim como sua fase adolescente: "Esta é a hora de aceitar os desafios da idade adulta para o bem da saúde bucal da população brasileira e também para a preservação do respeito e estima a que cirurgiões - dentistas têm direito".

O pensamento hegemônico sobre demanda por serviços odontológicos no país precisa transpor da ênfase ao modelo convencional, inerente ao paradigma cirúrgico restaurador, que é o resultado da doença, para o modelo de prevenção e 
controle, o paradigma da promoção em saúde, mantendo e atuando então sobre a saúde, sendo que a necessidade restante de tratamento deve ser efetuada com restaurações de alto nível de qualidade.

Bedford (1989, p.22), esclarece:

"A importância e os benefícios da prevenção das moléstias bucais são fatos incontestes. Mesmo que as discussões sobre as virtudes da prevenção comparadas às da assistência terapêutica não hajam terminado totalmente, o fato de que ambas são necessárias e devem funcionar de forma integrada é reconhecido".

O autor acrescenta que para grandes grupos populacionais a prevenção é o único caminho que nos dá esperanças de melhorar, no futuro, as condições de saúde bucal, ressaltando que: “O tradicional lema dos serviços odontológicos - "broca, obturação e conta" é, além de ineficaz, inaceitável."

Neste contexto, Werner [1989?] convoca os órgãos de classe, se realmente interessados em conter o número de dentistas saindo no mercado brasileiro que mudem o perfil da prática odontológica no país através da difusão de práticas preventivas, pois; “... assim o ciclo vicioso mais doença - mais profissionais poderá ser bloqueado".

Em 1994, o Governo Federal criou o Programa de Saúde da Família (PSF), oficializando-o em 1997, através da Portaria 1886 de 18 de dezembro (BRASIL, 1997), tendo como principal propósito reorganizar a prática da atenção à saúde em novas bases, levando à saúde para mais perto da família, buscando a melhoria da qualidade de vida dos brasileiros. O PSF prioriza as ações de promoção, proteção e recuperação da saúde dos indivíduos e da família, de forma integral e contínua, não se caracterizando, porém, como uma intervenção vertical e paralela às atividades dos serviços de saúde. Possibilita a integração e promove a organização das atividades em um território definido, sendo um instrumento importante na reorganização do 
modelo assistencial tradicional orientado para a cura de doenças e utilização do hospital. Tendo como público alvo a família, do recém - nascido ao idoso, sadios ou doentes - entendida e percebida a partir de seu ambiente físico e social concreto, possibilita uma compreensão ampliada do processo saúde/doença e da necessidade de intervenções que vão além de práticas curativas (BRASIL, 1997).

A partir do ano de 2000, uma ampla articulação realizada pela categoria odontológica, inclusive representada pela publicação dos artigos da Folha de São Paulo supracitados, através do Conselho Federal de Odontologia (CFO), da Associação Brasileira de Odontologia (ABO) e pelo fato do Ministério da Saúde considerar o Programa de Saúde da Família uma importante estratégia para consolidação do Sistema Único de Saúde, estabeleceurse a Portaria 1444, publicada no Diário Oficial da União (BRASIL, 2000), criando o incentivo financeiro para ações da inserção de profissionais da saúde bucal no Programa de Saúde da Família.

Esta Portaria objetiva ampliar o acesso da população às ações de promoção, prevenção e recuperação da saúde bucal, melhorar os índices epidemiológicos da população e incentivar sua reorganização na atenção básica, vislumbrando a possibilidade de reverter este quadro da inacessibilidade aos cuidados em saúde bucal.

Para que ocorra, então, a mudança do modelo de atenção em saúde vigente no país, caracterizado por priorizar as ações fragmentadas curativas e hospitalocêntricas, em direção a um modelo que promova a saúde, a integralidade, responsabilização e humanização, várias limitações e barreiras têm que ser vencidas, desde as macroestruturais, econômicas-sociais e políticas, até aquelas presentes nos microespaços, no cotidiano e na concepção dos atores sociais envolvidos. 
Considerando estas premissas apresentadas e a situação do ensino e da prática da odontologia no país, o presente trabalho propõe-se a analisar uma situação concreta de estratégia de integração ensino, pesquisa, serviço e comunidade em saúde bucal coletiva - a experiência do Projeto Saúde Bucal Coletiva, desenvolvido em instituição de nível superior privado, o Instituto de Ciências da Saúde do Centro Universitário do Triângulo - UNIT, no curso de odontologia, no município de Uberlândia, Minas Gerais.

O Projeto de Saúde Bucal Coletiva, do referido Centro Universitário, ministrado junto aos alunos do primeiro ao quarto ano do curso de odontologia, intitula-se; "Saúde Bucal Coletiva - Saúde e Cidadania: um projeto de integração social do aluno/comunidade sob a perspectiva da atenção primária em saúde e da humanização do ensino superior”.

O Projeto, no presente trabalho designado "Projeto Saúde Bucal Coletiva", referenda uma estratégia de ensino-serviço-comunidade na busca da implantação das diretrizes do SUS, a partir da ótica da formação voltada para a promoção em saúde, utilização de medidas preventivas de alcance coletivo, avanços da epidemiologia e da cariologia, humanização do ensino superior e promoção de mudanças nos modos de vida e atitude, tanto do estudante de odontologia bem como daqueles que são assistidos quando do exercício da atividade acadêmica.

O Projeto Saúde Bucal Coletiva busca uma mudança no modelo pedagógico, tanto quanto a conteúdos bem como a forma, com pedagogias mais reflexivas e críticas e que interaja com a prestação de serviços. Na prática, isso corresponde à criação dos sistemas que envolvam a comunidade, o serviço de saúde e a universidade. Os estudantes de odontologia trabalhando em situações que realmente 
acontecem na comunidade aonde os alunos vão tomando consciência dos problemas de saúde, tornando-se responsáveis e sendo participantes ativos da política de saúde.

As docentes responsáveis por este Projeto consideram que o aprendizado do aluno não estará completo sem a vivência das ações de promoção, proteção, recuperação e reabilitação da saúde, onde quer que elas aconteçam no município, seja nos hospitais, nas unidades de saúde, escola, creche, no domicílio ou em outras formas de organização social, onde o aluno, conhecendo e integrando-se efetivamente com programas e com uma equipe de saúde, conhecerá os problemas de maior prevalência e aprenderá a hierarquizá-los segundo sua importância. E é também ali que ele se informará sobre o complexo sistema assistencial em saúde coletiva - o SUS, onde, eventualmente, será chamado a atuar ou liderar.

Concordamos com Pinto (1996) quando analisa que a clientela do Serviço Local de Saúde Bucal, com base nas famílias e não nos indivíduos residentes na sua área de responsabilidade e influência, é uma alternativa positiva que pode substituir as modalidades tradicionais de organização das atividades odontológicas ou somar-se à parte delas. $\mathrm{O}$ autor evidencia o dilema na implantação de modalidades de organização da atenção odontológica, no PSF, representado pela substituição de modalidades versus complementação das mesmas. Assim, observamos que esta ocorrendo um movimento, em alguns municípios, quando da inserção da odontologia no PSF, promovendo a exclusão das modalidades ditas "tradicionais", sem realizar uma análise mais detalhada, conforme sugere o referido autor, ou seja, a complementação de algumas modalidades em desenvolvimento ao contrário de substitui-las. Encontramos, neste trabalho, por exemplo, que o atendimento em idade escolar, realizado por equipes odontológicas volantes dentro das escolas, não deveria 
ser substituído, considerando a sua facilidade de acesso, indicando sua reorganização no sentido de enfocar, também, a atenção às famílias destes escolares.

O Projeto Saúde Bucal Coletiva objeto desta dissertação trabalha com as premissas da Estratégia de Saúde da Família - ESF que se desdobram nos conceitos de humanização, vínculo, acesso, acolhimento, resolutividade e desenvolvimento da autonomia dos pacientes. Além destes aspectos, os pressupostos organizacionais desta proposta pedagógica incluem conforme menciona (Assis et al, 1996): visão de políticas públicas saudáveis, processos de territorialização em saúde, práticas sanitárias fundamentadas na concepção de Distrito Sanitário, romper com a dicotômica relação: ações promocionais e preventivas versus ações curativas e hospitalocêntricas, modelos de intervenção sobre a realidade local e prevenção dos riscos e agravos à saúde, modelo gerencial e informação em saúde.

Desta forma, o propósito deste trabalho materializa a descrição e análise, na forma de estudo de caso, de um projeto pedagógico de ensino - serviço - comunidade em saúde bucal coletiva, fornecendo elementos indicativos dos resultados deste Projeto a partir da experiência de quem o vivencia - o estudante do curso de odontologia.

Analisar, através de uma experiência universitária concreta, se os seus objetivos foram alcançados, na formação do aluno de graduação, representa identificar em que aspectos uma estratégia de ensino para o SUS, está apropriada como tecnologia na preparação do estudante de odontologia e conhecer os pontos de quebra ou contradição em suas teorias e operacionalização.

O ensino da saúde bucal coletiva não pode perder o "trem da história" ou, a oportunidade de recuperar o tempo perdido. Numa época de grandes mudanças, tanto 
nas condições objetivas de vida como das ideologias, da era da informática, da globalização e de complexas tecnologias, manter-se atualizado incorporando e buscando inovações em relação às políticas de saúde propostas, como a estratégia de saúde da família, acompanhando as transformações no setor de formação profissional em saúde, constitui-se num caminho promissor para a melhoria do sistema de ensino e em conseqüência a garantia de serviços que envolvem direitos fundamentais.

O processo de implementação de projetos de ensino, pesquisa e extensão universitária necessitam de uma avaliação constante, consistente e que gere recomendações pertinentes, pois se constitui numa oportunidade de atender à demanda de universidades e serviços públicos de saúde municipais, que vêm buscando alternativas de formação e preparação de recursos humanos para o SUS.

Romper com a tradição do modelo de ensino nas universidades é algo que leva tempo. Estudar a contribuição de um Projeto Pedagógico de Saúde Bucal Coletiva, na formação do estudante de odontologia, na perspectiva dos princípios do SUS e da atenção em saúde da família pode somar - se com as mudanças necessárias. É o que propomos nas paginas que se seguem. Para isso, nosso estudo esta organizado em cinco partes.

No primeiro capítulo, que é a Introdução definimos e delimitamos o problema em estudo: analisar a contribuição do Projeto Saúde Bucal Coletiva, através da visão dos estudantes de odontologia, que são os sujeitos, objetos primeiro do processo ensino aprendizagem. Em seguida trazemos a descrição do cenário de estudo: o Curso de Odontologia, o Centro Universitário do Triângulo - UNIT, a Secretaria Municipal de Saúde e o Município de Uberlândia, cenários aonde se desenvolve este Projeto em estudo. Ainda, neste capítulo descrevemos e enfocamos a proposta 
metodológica, organizacional e os objetivos educacionais do nosso estudo de caso O Projeto Saúde Bucal Coletiva. Finalizamos este capítulo com a exposição dos objetivos geral e específico deste nosso estudo.

No segundo capítulo, abordamos o referencial teórico que fundamenta o tema, subdividindo-o o em três partes, a saber: a primeira refere-se a necessidade de se repensar o processo de ensino aprendizagem da saúde bucal coletiva na universidade. Na segunda parte, buscamos a dimensão da saúde bucal coletiva na odontologia brasileira e na última e terceira parte tratamos da evolução do paradigma odontológico cirúrgico restaurador para o paradigma da promoção em saúde, sob a perspectiva dos avanços da epidemiologia e da cariologia, determinando mudanças no agir em odontologia.

O terceiro capítulo, diz respeito ao percurso metodológico utilizado para a realização da pesquisa e traz a população em estudo, os instrumentos e as questões éticas da pesquisa.

O quarto capítulo, Resultados e Discussão, refere-se a análise dos dados coletados através de dois questionários: o primeiro procura traçar o perfil, as condições sócio culturais e econômicas do estudante de odontologia e o segundo permite uma análise, sob a visão do estudante, sobre os motivos da escolha do curso, a análise das etapas do Projeto de Saúde Bucal Coletiva experenciadas, até às noções adquiridas em relação à diversos aspectos das atividades de ensino aprendizagem.

Nas considerações finais, procuramos fazer uma recuperação dos aspectos positivos e restritivos na implementação deste Projeto, assim como indicar alternativas para a superação das mesmas, a partir dos depoimentos dos sujeitos que 
vivenciaram a experiência de implementação da saúde bucal coletiva, durante o período de dois anos no curso de graduação em odontologia. 


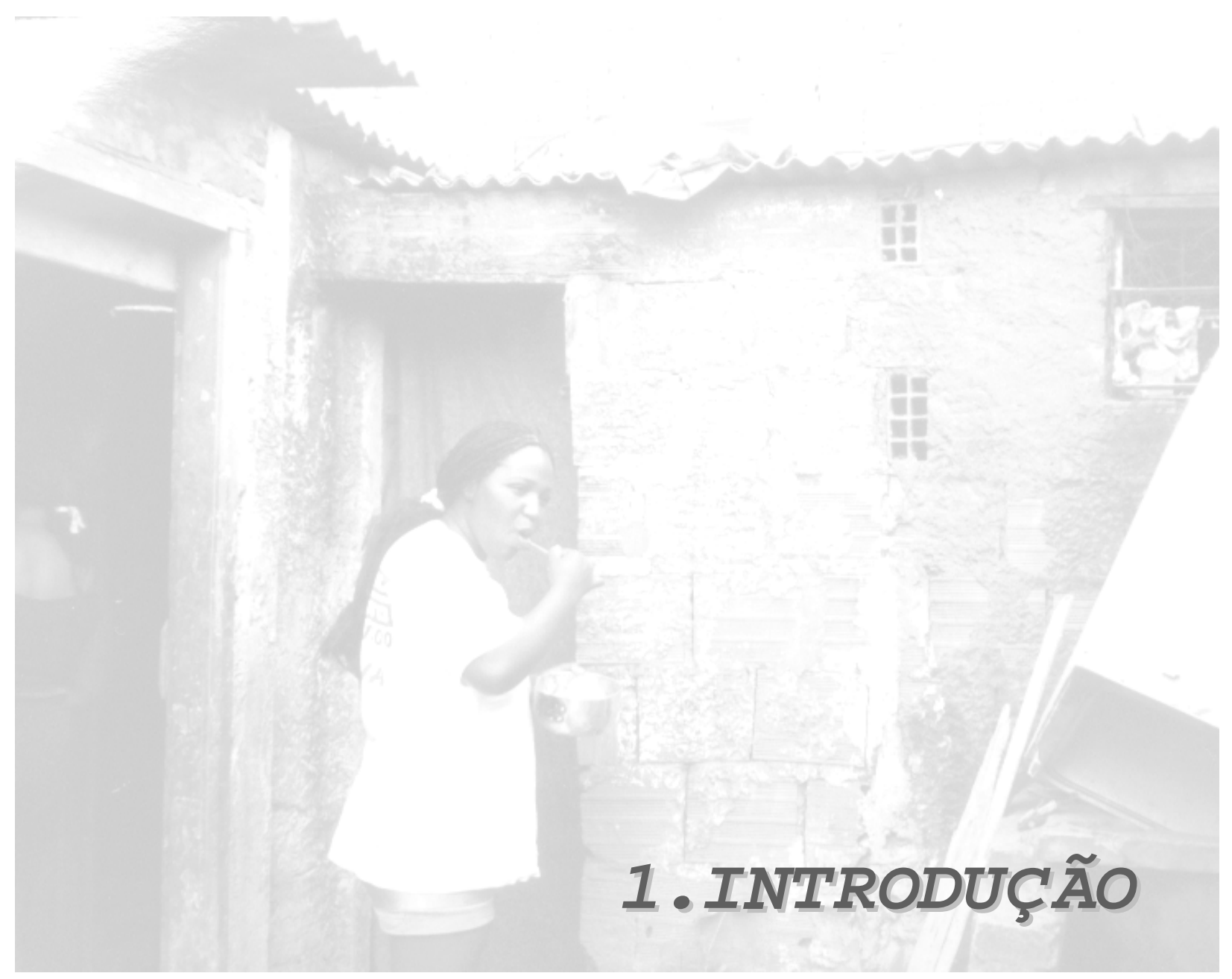




\subsection{DEFINIÇÃO E DELIMITAÇÃO DO PROBLEMA EM ES TUDO}

Esta dissertação trata-se de um estudo descritivo, cujo tema é o Projeto Saúde Bucal Coletiva, do Curso de Graduação em Odontologia, do Instituto de Ciências da Saúde, do Centro Universitário do Triângulo - UNIT, em Uberlândia, Minas Gerais, analisando se o mesmo contribuiu com a formação profissional do estudante de odontologia, para atuação em saúde bucal de alcance coletivo, enfatizando a promoção em saúde e a estratégia de saúde da família, sob a ótica deste estudante.

Contudo, neste estudo foi necessário fazer um recorte, por questões de tempo que se dispõe no mestrado, assim estudamos a abrangência do Projeto somente através da visão dos alunos, que são os sujeitos, objetos primeiro do processo ensino aprendizagem.

Assim, o Projeto foi avaliado junto aos alunos, que participaram de pelo menos dois anos de suas atividades pedagógicas, desde o período em que foi implantado, em agosto de 1999 a setembro de 2002.

O projeto pesquisado: Saúde Bucal Coletiva - Saúde e Cidadania, envolveu, até setembro de 2002, 247 alunos do curso de odontologia, atendendo mais de 500 famílias e aproximadamente 1.300 crianças em idade escolar. A primeira etapa do Projeto foi aprovada através de parecer técnico da Comissão de Pesquisa e Extensão da UNIT, em dezembro de 1999, sendo que a mesma foi divulgada durante a $4^{\text {a }}$ Reunião Anual de Ciências (REUNIÃO - 4, 2000), desta instituição, em outubro de 2000, assim como no jornal informativo da UNIT, apresentado no Anexo A 
(PROJETO..., 2000) e em matérias da imprensa escrita e falada dos meios de comunicação local.

Ressaltamos que, ainda no mesmo ano de implantação da primeira etapa do Projeto Saúde Bucal Coletiva, em 1999, observando-se a repercussão positiva do mesmo entre os alunos do curso de odontologia, ocorreu a extensão de sua primeira etapa, também, para o $7^{\circ}$ período do Curso de Fisioterapia, através das disciplinas Introdução à Saúde Pública e Ciências Sociais Aplicadas à Saúde, denominando-se Projeto Saúde e Cidadania.

O Curso de Odontologia, no qual o Projeto em questão é desenvolvido, é recém criado e iniciou sua primeira turma a partir de fevereiro de 1999, sendo que o Projeto Saúde Bucal Coletiva passou a ser aplicado a partir do $2^{\circ}$ período do curso, em agosto de 1999. O Projeto é de autoria de quatro docentes do Centro Universitário supracitado, sendo que me integro ao mesmo como co-autora. Procuramos ministrar o ensino da saúde coletiva, voltado para o tendimento às necessidades sociais predominantes e para a construção do Sistema Único de Saúde SUS, sob o enfoque da estratégia de saúde da família.

No início deste projeto, em 1999, ocorria uma integração com o Programa de Saúde da Família, desenvolvido pelo município de Uberlândia, denominado Programa Família Saudável e a Coordenação de Ações em Odontologia, da sua Secretaria Municipal de Saúde. Contudo, com a mudança de gestão política do município, a partir do ano de 2001, as quatro equipes do "Programa Família Saudável" foram desativadas inviabilizando nossa participação integrada.

No momento, o Projeto Saúde Bucal Coletiva integra-se às unidades de saúde da rede básica do SUS, do município e a Clínica Odontológica da UNIT. Definimos 
dois bairros de atuação: Joana D'arc e Shopping Park, utilizando como critério de escolha comunidades em condições sociais e econômicas desfavorecidas.

O Projeto como será visto adiante mantém todas as atividades práticas voltadas para a família, em território pré-estabelecido, em torno da unidade de saúde da rede básica do SUS. Os estudantes de odontologia atuam em etapas do Programa Saúde da Família, através do cadastramento das famílias com visitas domiciliares, levantamento sócio - econômico, epidemiológico, assim como das condições de infra - estrutura, de equipamentos sociais e de serviços públicos no bairro eleito para o trabalho sugerido, inicialmente, pela direção do Programa no município de Uberlândia. Nas etapas subseqüentes ocorre o diagnóstico, análise de situação, proposta de ação e execução de programas envolvendo a promoção, prevenção e ações clínicas e restauradoras em saúde bucal.

O entendimento do novo modelo assistencial proposto pelo Ministério da Saúde, através da estratégia do Programa Saúde da Família, oficializado em 1997, e implantado atualmente em mais de 3000 municípios brasileiros, e de demais estratégias de alcance coletivo ${ }^{1}$, proporciona aos alunos do curso de odontologia a possibilidade de aliar o conhecimento teórico ao prático tanto das disciplinas Odontologia Coletiva I e II, Orientação Profissional I e II, Programas Odontológicos Coletivos I e II, quanto do conteúdo das Ciências Sociais Aplicadas à Saúde, que o insere em uma realidade política/sócio/cultural, oportunizando também a eles, o contato com uma vertente do mercado de trabalho para os profissionais da área de saúde pública e social.

\footnotetext{
${ }^{1}$ Considera-se como demais estratégias de alcance coletivo os procedimentos coletivos representados pelas ações preventivas de higienização e fluort erapia, através de aplicações tópicas com escovas de dente e moldeiras descartáveis, junto aos escolares da rede de ensino fundamental, da rede pública.
} 
Pinto (2000) afirma que em contradição aos avanços ocorridos no século XX, particularmente em suas três últimas décadas, de uma odontologia cada vez mais eficiente e de melhor qualidade, capaz de oferecer alternativas técnicas de crescente sofisticação e praticidade para solucionar os problemas de saúde bucal, o Brasil fica na contramão da história:

“... países em desenvolvimento, como é o caso do Brasil chegam ao vigésimo primeiro milênio sem uma política definida de saúde bucal e com significativas parcelas da população sem conseguir acesso a cuidados clínicos e preventivos essenciais de maneira regular". (PINTO, 2000, p.1)

Segundo Torres (1992), o Brasil é o país que possui o maior número de curso de formação de odontólogos no mundo, o que representa $11 \%$ do total. Verifica-se no Brasil um "boom" de escolas, acompanhado de uma elevada demanda (aluno/vagas) pelos cursos de odontologia, superando a tradicional posição privilegiada da medicina.

No entanto, conforme menciona Teixeira (1995) apesar da marcante presença do cirurgião - dentista no mercado, ainda persistem sérios problemas da ordem da saúde bucal no Brasil, como a elevada prevalência de cáries.

De acordo com o documento do Ministério da Saúde, “como o modelo de ensino, com contadas exceções, permanece com um talhe tradicional, com forte base curativa e voltada para o exercício liberal da profissão, na prática não consegue alterar a situação vigente”. (MINISTÉRIO DA SAÚDE, 1990).

Contudo, até que ponto os profissionais graduados em odontologia, nas universidades brasileiras, adotam práticas inovadoras e estão sensibilizados para a importância de adotar o enfoque da saúde da família e enfatizar um forte vínculo com os serviços de atenção primária à saúde e com a comunidade, para enfrentar os 
problemas da odontologia citados? Por outro lado, a conjuntura e o mercado de trabalho que recebe o dentista permitirá colocar em prática esta visão holística da problemática de saúde, atuando conjuntamente com outros setores sociais se quiser intervir, de forma efetiva, sobre os determinantes do processo saúde - doença? Estas são as grandes questões de fundo que permeiam este trabalho, com as quais tentarei dialogar.

Esperamos, assim, contribuir com uma experiência simples que vem tentando obter respostas positivas a um dos problemas mais desafiadores para a efetiva implementação do Sistema Único de Saúde - a formação de um profissional preparado e sensibilizado para atender as necessidades de saúde da população e que incorpore a importância e o impacto das dimensões sócio - econômicas, políticas e culturais para a saúde no seu agir. Esperamos também contribuir com uma alternativa de ensino aprendizagem que possa ser implantada em outras universidades, neste momento em que a procura por saídas, tanto para a educação quanto para os serviços públicos de saúde no país é urgente e necessária.

Em seguida descrevemos a proposta metodológica e organizacional do Projeto Saúde Bucal Coletiva - Saúde e Cidadania e seus principais aspectos relacionados aos cenários em que está inserido, ou seja, o Curso de Odontologia, o Centro Universitário, a Secretaria Municipal de Saúde e o município de Uberlândia. Posteriormente, apresentamos seus objetivos educacionais e suas etapas, que foram planejadas e subdividas semestralmente, associando o conteúdo programático do primeiro ao quarto ano do curso de odontologia, com atividades práticas voltadas para ações em atenção básica coletiva e clínica restauradora individual, conforme o risco em adoecer das enfermidades bucais. 


\subsection{O Curso de Odontologia, o Centro Universitário do Triângulo, A SECRETARIA M UNICIPAL DE SAÚDE E O MUNICÍPIO de UbERLÂNDIA}

O Curso de Odontologia, referido neste projeto, insere-se em uma instituição de ensino superior privado, denominado "Centro Universitário do Triângulo UNIT”, originado enquanto instituição de ensino em 1924, consolidado como Centro Universitário em 1994. O Curso de Odontologia é recém criado, iniciando sua primeira turma a partir de fevereiro de 1999. Assim, disponibilizará seus primeiros graduandos, para o mercado de trabalho, ao final do mês de dezembro de 2003, compreendendo os cinco anos letivos de graduação em odontologia.

Acreditamos que o fato do curso de odontologia, no qual está o projeto eleito para o presente estudo de caso, estar em sua primeira turma, apresenta um lado restritivo, uma vez que limita a análise do impacto do trabalho desenvolvido, junto aos profissionais, caso já tivessem sido graduados por este curso e já atuando na nossa realidade social.

Todavia, percebemos que outros aspectos compensam estas restrições, considerando que este Projeto enfoca um tema atual de forma inovadora para os caminhos da odontologia na abordagem coletiva, inclusive na estratégia de saúde da família.

O Projeto analisado é desenvolvido, no município de Uberlândia, situado no extremo oeste do estado de Minas Gerais, na região denominada de Triângulo Mineiro. Constitui-se em um importante entroncamento rodo-ferroviário que facilita a comunicação com os principais centros urbanos da região sudeste e centro-oeste. 
A localização privilegiada favorece o seu crescimento e desenvolvimento sendo hoje o $3^{\text {o }}$ maior município do estado, com uma população de 502.416 habitantes, segundo o censo demográfico e estimativo do IBGE, 2000 (DATASUS, 2000). Possui uma infra-estrutura urbana considerada invejável para os padrões encontrados no país, apresentando $80 \%$ das vias públicas com pavimentação asfáltica e $98 \%$ da área urbana coberta pelo transporte coletivo. Com relação a outros serviços temos que, $94 \%$ das residências possuem rede elétrica, a rede pública de abastecimento de água atinge $99,8 \%$ da população, possuindo duas fontes de captação e tratamento[...] A rede de esgoto beneficia 97,8\% das residências, estando em construção sete estações de tratamento (SALOMÃO et al., 1999).

A rede de ensino em Uberlândia é composta por uma Universidade Federal, um Centro Universitário e duas Faculdades privadas. A Universidade Federal, disponibiliza 2.080 vagas para alunos ingressantes, conta inclusive com o curso de odontologia, desde a década de 1970, sendo que o Centro Universitário do Triângulo - UNIT, oferece aproximadamente 1.870 vagas para o ingresso em seus vários cursos, inclusive os do setor saúde nas seguintes áreas; Odontologia, Fisioterapia, Enfermagem, Farmácia, Nutrição, Psicologia e Educação Física.

O Centro Universitário do Triângulo, onde se desenvolve o Projeto em estudo, originou-se, como Escola Normal do Uberabinha, dedicada ao ensino fundamental. Em 1947, passou a oferecer, também, o equivalente ao Ensino Médio, sendo que em 1966 passou a abrigar a Escola Técnica de Química Industrial. A primeira Faculdade, a de Serviço Social, teve seu funcionamento autorizado em 1972, sobrevindo-lhe em seguida outros cursos. Em 1990, o agrupamento de quatro faculdades deu à instituição, a denominação de Faculdades Integradas do Triângulo - 
FIT. O ano de 1994 marcou a grande arrancada da FIT rumo à sua consolidação como Centro Universitário, com a aprovação de cinco novos cursos. Por transformação da FIT, o Centro Universitário do Triângulo - UNIT, foi credenciado por decreto presidencial em outubro de 1997. A transformação, pela autonomia conferida à UNIT, permitiu-lhe executar seu Plano de Expansão para mais nove cursos. (UNIT - Pró Reitoria de Ensino e Graduação, 2000).

A estratégia de integração ensino, serviço e comunidade aqui analisada, como dito anteriormente, promove atividades integradas à rede SUS deste município, coordenada pela Secretaria Municipal de Saúde (SMS), sendo que a mesma foi criada em 1983, porém sua instalação oficial aconteceu em fevereiro de 1984, assumindo a partir de então, de forma mais expressiva, os serviços de saúde básicos a serem prestados à população.

A partir de 1991, com o início da municipalização, a SMS assumiu a gestão da rede ambulatorial do estado e também da rede privada contratada. Neste período, a rede municipal experimentou um grande crescimento, com a criação de serviços de urgência, emergência, além dos ambulatoriais. Serviços especializados e de apoio e diagnóstico foram implantados, estruturando um sistema de informatização e a conseqüente remodelação administrativa.

O Sistema Único de Saúde em Uberlândia conta com uma ampla rede de serviços básicos em saúde, estando atualmente em Gestão Plena do Sistema, conforme estabelecido pela Norma Operacional da Assistência -NOAS - SUS 2002-01 (BRASIL, 2002). Compõe-se em dois grandes prestadores públicos de ações e serviços de saúde; a Secretaria Municipal de Saúde (SMS), representada por uma extensa rede básica, 14 Unidades Básicas de Saúde, e 05 Unidades de Atendimento 
Integrado, também denominadas "UAI" ou "Hospital de Bairro", e o Complexo da Universidade Federal de Uberlândia (UFU), FAEPU (Fundação de Assistência ao Ensino e a Pesquisa em Uberlândia) e o Hospital das Clínicas, representando, principalmente, as ações de nível terciário e quaternário de atenção à saúde. A sua rede privada conveniada é constituída, basicamente, por 04 hospitais particulares, responsabilizando-se pelas internações que o Hospital das Clínicas não consegue absorver.

Com estas características e serviços o Índice de Desenvolvimento Humano IDH, de Uberlândia, calculado pela Fundação João Pinheiro, situa-se na faixa entre médio e alto: IDH = 0,795 (SALOMÃO et al., 1999). 
1.3 O ESTUDO DE CASO: O PROJETO SAÚDE BUCAL COLETIVA - SAÚDE E CIDADANIA

\section{PROJETO SAÚDE BUCAL COLETIVA}

SAUUOE E CIDADANA: um projeto de integraçäo social do aluno/ comunidade sob a perspectiva da atenção primária em saúde e da humanização do ensino superior

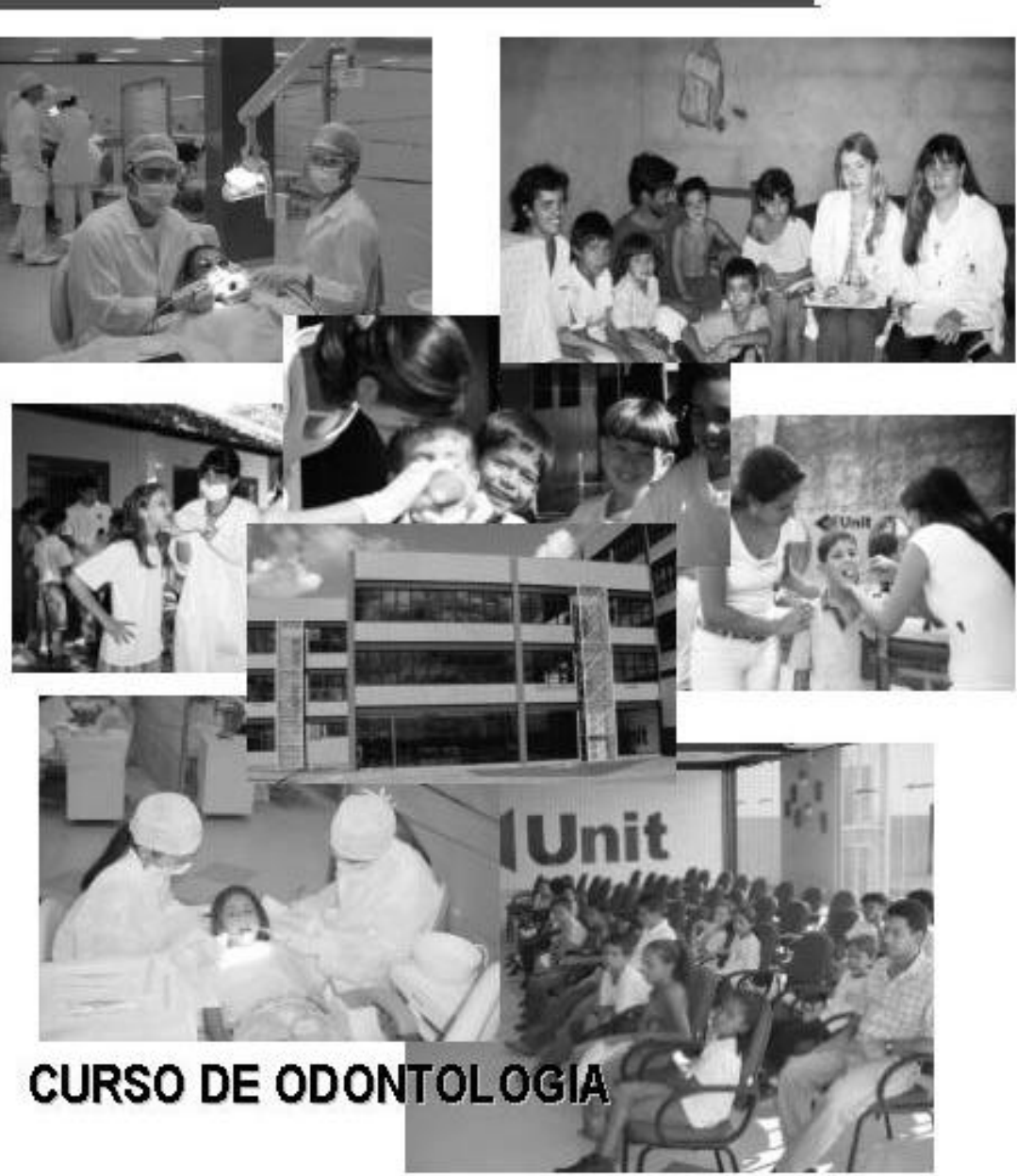

Uberlândia - MG

2002 
O "Projeto Saúde Bucal Coletiva - Saúde e Cidadania: um projeto de integração social aluno/comunidade sob a perspectiva da atenção primária em saúde e da humanização do ensino superior", procura integrar universidade/comunidade, ensino/pesquisa e extensão, objetivando sensibilizar e capacitar o aluno para incorporar um conceito ampliado de saúde, adotando uma postura preventiva para atuar em abordagens de alcance coletivo, sob a perspectiva da promoção em saúde, preparando-o, também, para atuar na estratégia de saúde da família, preconizada pelo Ministério da Saúde.

Envolve o Centro Universitário, a Secretaria de Saúde, demais equipamentos sociais e a comunidade. Representa a valorização dos princípios da municipalização e descentralização da saúde, preconizados pelo SUS. Promove a integração do aluno do curso de odontologia, com a comunidade, dinamizando o ensino nos aspectos promocionais, sociais e organizacionais da saúde coletiva, proporcionando ao aluno a vivência com as práticas e os processos sociais em que profissionais da equipe de saúde e usuários do sistema público de saúde - SUS estão inseridos, colocando-o mais precocemente possível, na prática com as condições reais de saúde da população brasileira, estimulando, promovendo e valorizando o comportamento analítico, crítico e criativo.

Sobre a gênese do Projeto Saúde Bucal Coletiva, inicialmente, foram criadas as disciplinas de Odontologia Coletiva 1/ Programa de Saúde da Família e Ciências Sociais Aplicadas à Saúde, ministradas durante o $2^{\circ}$ período do Curso de Odontologia, do referido Centro Universitário. Reconhecendo o incentivo demonstrado pela UNIT e a coordenação do Curso de Odontologia aos planos de ensino que contemplassem a interdisciplinaridade, o Projeto foi pensado e redigido a 
quatro mãos pelas docentes responsáveis pelas disciplinas supracitadas e referendado, em seguida, pela Comissão de Ensino, Pesquisa e Extensão do Centro Universitário do Triângulo - UNIT.

Em seguida, foram contratadas mais duas docentes para, também, ministrar aulas no quadro das disciplinas de odontologia coletiva, orientação profissional e Programas Odontológicos Coletivos, ao longo dos cinco anos do curso de odontologia. Para elaboração do Projeto foi imprescindível a contribuição das docentes trazida da longa experiência de atuação e administração junto ao serviço de saúde bucal da Secretaria Municipal de Saúde, do município de Uberlândia, e outras experiências de diversos projetos desenvolvidos nesta área, alinhavando, assim, a continuidade das atividades práticas iniciadas durante o $2^{\circ}$ período do curso.

A continuidade do Projeto Saúde Bucal Coletiva significava para estas docentes um convite não apenas à reflexão sobre a possibilidade, natureza e estratégias de mudanças necessárias em saúde e na educação de profissionais de saúde, mas, também vislumbrar a possibilidade real de reformular a graduação do odontólogo, resgatando responsabilidades históricas como a equidade, a justiça social, a melhoria das condições de vida e saúde e seus determinantes e o agir em saúde enfocando a atenção primária, com ênfase na saúde da família, na promoção da saúde, e nos aspectos educativos, e a articulação da intersetorialidade e da integração da atenção.

Assim, tinha-se com certeza uma possibilidade de trazer algo em que acreditávam, para formação do aluno através da experiência desenvolvida junto a rede básica do Sistema Único de Saúde de nosso município. Sabia-se o que poderia ser reformulado, mas não tínham muito claro como fazê-lo e que resultados seriam 
alcançados. Assim, de forma gradual, foram implementando o conteúdo teórico associado às atividades práticas de alcance coletivo embasadas muito mais pela intuição do que por outras experiências acadêmicas ou revisão bibliográfica.

Os alunos atuam nas etapas preconizadas pela estratégia de saúde da família, incluindo o cadastramento, o mapeamento, diagnóstico e Plano de Ação, junto a comunidade e integrado aos serviços e programas disponibilizados pelo SUS e demais serviços das Secretarias da Prefeitura de Uberlândia. Conhece o funcionamento e as necessidades da rede básica do SUS, atua em escolas públicas, nos domicílios e creche. Realizam o atendimento preventivo, clínico e restaurador em saúde bucal de parte da comunidade envolvida.

O Projeto possibilita ao aluno o conhecimento e compreensão do caráter histórico e estrutural da saúde coletiva, que significa aproximar-se dos métodos, processos, organização e forma de atuação das várias áreas da saúde, presentes no mundo real.

As disciplinas que dão suporte ao projeto abordam os conteúdos da epidemiologia, da saúde coletiva, do planejamento em saúde e suas implicações com as políticas sociais e de saúde, analisando o papel do Estado e a formulação de sua política, assim como de suas estratégias de promoção em saúde e organização da atenção básica.

O conteúdo programático das disciplinas envolve, também, o estudo das principais doenças bucais, da programação em Odontologia Coletiva, da educação em saúde e dos métodos preventivos da cárie e da doença periodontal, a biossegurança, a ética e a postura profissional situados no contexto político, econômico e sócio - cultural brasileiro. 
Propõe-se, assim, a inter-disciplinariedade e a preparação para o trabalho, através de projetos integrados com a comunidade, partindo do interesse do aluno, do tipo de sistema de saúde e epidemiologia locais, do estímulo da instituição e, principalmente, da disponibilidade interna e o interesse em contribuir com as mudanças necessárias à saúde coletiva, demonstrada pelos professores responsáveis pelas disciplinas, que dão suporte ao Projeto.

\subsubsection{Proposta metodológica e organizacional}

O Projeto iniciourse em agosto de 1999, junto aos alunos do $2^{\circ}$ período, sendo que as suas atividades prosseguem até o $8^{\circ}$ período, excetuando-se o $1^{\circ}$, o $6^{\circ}$, o $9^{\circ}$ e o $10^{\circ}$ períodos, conforme demonstrado na Tabela 1 , sendo que a primeira turma do Curso de Odontologia irá graduar-se ao final do ano de 2003.

Tabela 1 - Participação do projeto saúde e cidadania, segundo o semestre e o período do curso, nos anos de 1999 a 2002, UNIT, Uberlândia, MG, 2002

\begin{tabular}{|c|c|c|c|}
\hline ANO & SEMESTRE & PERÍODO & $\begin{array}{l}\text { PARTICIPAÇÃO NO PROJETO } \\
\text { SAÚDE BUCAL COLETIVA }\end{array}$ \\
\hline \multirow{2}{*}{1999} & Primeiro & $1^{\circ}$ período & Não \\
\hline & Segundo & $2^{\circ}$ período & Sim \\
\hline \multirow{2}{*}{2000} & Primeiro & $3^{\circ}$ período & Sim \\
\hline & Segundo & $4^{\circ}$ período & Sim \\
\hline \multirow{2}{*}{2001} & Primeiro & $5^{\circ}$ período & Sim \\
\hline & Segundo & $6^{\circ}$ período & Não \\
\hline \multirow{2}{*}{2002} & Primeiro & $7^{\circ}$ período & Sim \\
\hline & Segundo & $8^{\circ}$ período & Sim \\
\hline
\end{tabular}


O Projeto divide-se em cinco etapas, correspondentes a três anos de atividades teóricas e práticas integradas e contínuas, conforme demonstrado sinteticamente, no Anexo B.

Em sua primeira e segunda etapa, durante o $2^{\circ}$ e $3^{\circ}$ períodos do curso, caracteriza-se por colocar os alunos em contato com a realidade social de uma região sócio, econômica e culturalmente desfavorecida e, também, de uma escola periférica pública de ensino fundamental. O aluno depara-se com as necessidades básicas de saúde da população e da comunidade escolar, aprendendo a utilizar o suporte institucional oferecido através da rede do Sistema Único de Saúde - SUS de Uberlândia e busca alternativas para os problemas encontrados, através do diagnóstico, análise de situação e elaboração de um plano de ação.

Na segunda etapa, o aluno aprende a planejar e executar medidas de prevenção das principais doenças bucais para crianças em idade escolar, conforme o risco individual de adoecer.

$\mathrm{Na}$ terceira e quarta etapa, correspondente ao $4^{\mathrm{o}}$ e $5^{\mathrm{o}}$ períodos, o aluno passa a atuar no domicílio das famílias e em uma creche pública. O projeto promove a inserção da odontologia na visão estratégica da reorganização da atenção básica, tendo como porta de entrada o programa de saúde da família, sob a perspectiva de uma prática preventiva viável e contributiva para a melhoria do perfil de morbidade das principais doenças bucais.

Finalmente, na quinta e última fase, correspondente ao $7^{\circ}$ e $8^{\circ}$ períodos, dando continuidade ao trabalho desenvolvido nos períodos anteriores, estes alunos aplicam o critério da equidade para selecionar as crianças que irão necessitar de atendimento clínico restaurador. São utilizados critérios de riscos de adoecer em 
relação às doenças bucais mais prevalentes, possibilitando identificar parcelas da comunidade escolar que necessitam de cuidados prioritariamente. Assim, nestes dois períodos ocorrem os atendimentos na clínica odontológica do Centro Universitário do Triângulo - UNIT, completando um ciclo de atenção preventiva e reabilitadora para esta comunidade escolar.

Pretendemos gradualmente, incluir para o atendimento clínico, restaurador e cirúrgico, na clínica odontológica da UNIT, também, as famílias cadastradas pelos alunos, nas outras etapas do projeto. Atualmente, utilizamos o encaminhamento destas famílias, para as unidades básicas da rede SUS do município, que se encontram mais próximas de suas residências, porém este encaminhamento não tem se mostrado suficiente para a demanda cadastrada, principalmente no que se refere as necessidades bucais.

Como veremos a seguir, o projeto busca o entendimento e a aplicação prática do novo modelo assistencial proposto pela Estratégia de Saúde da Família do Ministério da Saúde, proporcionando aos alunos a possibilidade de aliar o conhecimento teórico ao prático da Saúde Coletiva, Saúde Bucal e do conteúdo das Ciências Sociais aplicadas à Saúde.

\subsubsection{Objetivos Educacionais e Etapas do Projeto}

O Projeto Saúde Bucal Coletiva do Curso de Odontologia tem por finalidade formar profissionais conhecedores da realidade local, com postura e atitude preventiva, abertos às necessidades da população, viabilizando noções de cidadania e o estabelecimento de relações mais humanas, responsáveis e comprometidas com a 
resolução dos problemas de saúde e sociais da comunidade, enfatizando a atenção primária, a saúde da família e a necessidade de articulação entre os diversos níveis de complexidade do setor saúde.

Visa, também, ampliar o conceito de saúde-doença-cuidado para além dos aspectos biológicos, compreendendo que se trata de um processo complexo que tem determinações biológicas, sociais e culturais, como, condições de trabalho, alimentação, saneamento, educação, enfim, que leve em consideração as condições concretas de vida das pessoas.

O modelo pedagógico adotado pelo Projeto Saúde Bucal Coletiva têm dois conceitos chaves: o primeiro é que deve se aprender fazendo, invertendo a seqüência clássica teoria/prática, caracterizando que o processo do conhecimento ocorre na ordem inversa, ou seja, da prática para a teoria; e o segundo conceito traz a necessidade de aperfeiçoamento contínuo de atitudes, conhecimentos e habilidades do aluno, através de uma pedagogia de interação que privilegia o aprendizado, baseado em problemas e orientado para a comunidade e os serviços de saúde.

Outra questão que se inscreve como fundamental sobre os aspectos educacionais do Projeto refere-se ao fato, muito bem delineado pelo Projeto UNI Uma Nova Iniciativa na Educação dos Profissionais de Saúde: União com a Comunidade, conforme menciona Almeida (1999):

“...os conhecimentos, habilidades e atitudes exigidas do profissional
modificam-se rapidamente. Assim o aluno precisa desenvolver as
habilidades de busca, seleção e avaliação crítica de dados e
informações disponibilizadas em livros, periódicos, bases de dados
locais e remotas, além da utilização das fontes pessoais de informação,
incluindo a advinda de sua própria experiência profissional.”

Em vez de disciplinas ministradas nos moldes tradicionais, propõe-se a preparação para o trabalho, projeção para fora dos contextos estritamente 
acadêmicos, sair do confinamento da sala de aula, para compreender o significado social do trabalho do dentista em uma comunidade. A abordagem tenta captar o interesse do aluno e motivá-lo para conhecer a organização do Sistema de Saúde brasileiro e do município local, bem como, os dados epidemiológicos do processo saúde-doença locais. É preciso também que haja estímulo da instituição e, da disponibilidade interna e o interesse em contribuir com as mudanças necessárias na saúde coletiva, demonstrada pelos docentes responsáveis pelas disciplinas, que dão suporte aos conteúdos da saúde bucal coletiva e das ciências sociais, no currículo do curso de odontologia.

Abordaremos, a seguir os conteúdos educacionais e as atividades práticas de cada disciplina que dão suporte ao Projeto, definindo suas etapas. Os objetivos educacionais foram sendo traçados, à medida que os alunos percorriam os períodos.

\section{a) Primeira Etapa: $2^{\circ}$ período do Curso de Odontologia}

As disciplinas, do $2^{\circ}$ período, envolvidas nesta etapa são Odontologia Coletiva 1/ Programa de Saúde da Família e as Ciências Sociais Aplicadas à Saúde que atuam de forma integrada.

A disciplina denominada Odontologia Coletiva 1/ Programa Saúde da Família, aborda os dados epidemiológicos do processo saúde - doença no Brasil e no município em questão, as modificações nos padrões de morbimortalidade e implicações com as políticas sociais e de saúde, analisando o papel do Estado na questão da saúde e a formulação de sua política, assim como de suas estratégias de promoção em saúde e organização da atenção básica, inclusive a Estratégia de Saúde da Família. 
A disciplina de Ciências Sociais Aplicadas à Saúde, aborda as questões relacionadas às concepções de corpo, através do processo histórico e na vida cotidiana, o poder e o corpo na sociedade capitalista, a família e o controle social.

Objetiva introduzir o aluno nas unidades de saúde da rede básica do SUS, para posteriormente colocá-lo em contato com as primeiras etapas da Estratégia de Saúde da Família (ESF), as visitas domiciliares e o cadastramento em saúde, preconizado pelo Ministério da Saúde. Para as visitas as unidades da rede SUS, do município de Uberlândia, utilizam dois roteiros, observação direta e entrevistas com usuários e trabalhadores da saúde, distribuindo os alunos em unidades localizadas em diferentes distritos sanitários.

Esta etapa de conhecimento da rede SUS, parte da perspectiva de que o Programa de Saúde da Família é uma estratégia para a organização da atenção básica no município, mas que não garante isoladamente a integralização da atenção à saúde. Considera, então, que esta integralização, passa pela implementação de uma rede básica de saúde e, gradualmente, dos princípios do SUS. Prepara o aluno para inteirar-se dos programas e serviços oferecidos pela rede básica, tendo como finalidade divulgá-los, quando das visitas domiciliares e cadastramento, junto à comunidade.

Após o (re)conhecimento da rede SUS, o aluno parte para a identificação das patologias e problemas prevalentes em saúde de uma comunidade previamente estabelecida e mapeada, que apresenta realidade sócio-cultural e econômica desfavorecida. Para esta finalidade, emprega-se as visitas domiciliares e o cadastramento familiar. Para o cadastramento, utiliza-se da ficha A, de cadastramento familiar das condições de saúde, moradia, saneamento e informações 
gerais (meios de comunicação, planos de saúde utilizado e outros informações), definido pelo Sistema de Informação Ambulatorial Básico (SIAB) do Ministério da Saúde, acrescido de algumas informações sobre vetores, orientadas pelo Centro de Controle de Zoonoses, do município de Uberlândia.

Para identificar doenças bucais referidas, hábitos de higiene bucal, dieta alimentar e necessidade de prótese utilizam-se uma ficha elaborada, em 1998, pela coordenação de saúde bucal do Programa Família Saudável, da Secretaria de Saúde de Uberlândia.

Para atuarem na comunidade, realizando as visitas domiciliares $\mathrm{e} o$ cadastramento em saúde /saneamento/moradia e o levantamento de necessidades específicas em odontologia, os alunos são orientados para adotarem uma postura informativa, educativa e solidária junto às famílias visitadas. Esta etapa é concluída elaborando-se um diagnóstico de realidade e um plano de ação, junto às lideranças do bairro, deparando-se com o perfil epidemiológico da realidade sanitária e odontológica destas comunidades, na busca de alternativas para a situação encontrada. Os alunos consolidam um diagnóstico da situação de perfil de morbimortalidade, condições de vida e moradia e em seguida classificam as famílias em situação consideradas de risco leve, moderado, grave ou sem risco, conforme estabelecido pelo Programa Família Saudável (PFS) da Secretaria de Saúde de Uberlândia e adaptado, na área odontológica pelas docentes responsáve is por esta etapa, conforme Anexo C. Em seguida, registra em mapas as situações encontradas que demarcam risco a saúde e promovem, também, o encaminhamento dos dados coletados a(s) unidade(s) básica(s) de saúde adscritas ao bairro eleito para o trabalho 
de campo, solicitando a atenção e atendimento pelos profissionais da rede básica do SUS às famílias classificadas em risco moderado e grave de adoecer.

Antes da realização das visitas domiciliares, são organizadas palestras e oficinas, sobre aspectos importantes relacionados à vigilância em saúde, para que os alunos possam ir além da coleta de dados e contribuir com orientações básicas, encaminhamentos para a rede SUS e desenvolver um olhar crítico e uma postura preventiva voltada para a vigilância em saúde.

Para estas palestras e oficinas são convidados coordenadores e profissionais da Secretaria de Saúde, proporcionando informações e orientações básicas referentes aos programas de imunização, controle de zoonoses, vigilância epidemiológica e sanitária. Estas informações são consideradas indispensáveis ao cadastramento familiar, que os alunos realizam no bairro ou no conjunto de bairros delimitados para o trabalho de campo.

Concluindo esta etapa, ocorre a execução de um plano de ação, centrado em promoção de saúde e voltado para os grupos e demandas de maior necessidade, encontrados através dos levantamentos de doenças referidas realizadas, junto à população residente desta comunidade.

Os objetivos educacionais desta etapa são:

- Identificar as características sociais, econômicas e demográficas e epidemiológicas de uma comunidade pré-estabelecida, socialmente excluída;

- Identificar os problemas prevalentes relacionados à saúde da comunidade e as suas condições de vida (condições de transporte, educação, cultura, lazer e segurança); 
- Identificar a situação odontológica, higiene bucal, padrão de consumo de açúcar, hábitos nocivos à saúde, hábitos alimentares das famílias visitadas, assim como os problemas prevalentes da cavidade bucal;

- Conhecer o funcionamento e as necessidades dos serviços da rede básica de saúde local;

- Realizar a tabulação e consolidação dos dados epidemiológicos levantados, através da utilização do Sistema de Informação Ambulatorial - SIAB e dos formulários de cadastramento das famílias, preconizado pelo Programa Oficial de Saúde da Família, do Ministério da Saúde;

- Discutir com as lideranças do bairro e representantes do poder público das áreas envolvidas (Saúde e Ação Social) a problemática em saúde encontrada;

- Elaborar e executar um Plano Local para o enfrentamento dos determinantes do processo saúde/doença e condições sociais e exercício da cidadania predominante no bairro cadastrado.

A figura 1 demonstra os estudantes de odontologia na realização da visita domiciliar e cadastramento das condições gerais de saúde, moradia, saneamento e demais informações. Uberlândia, 1999. 


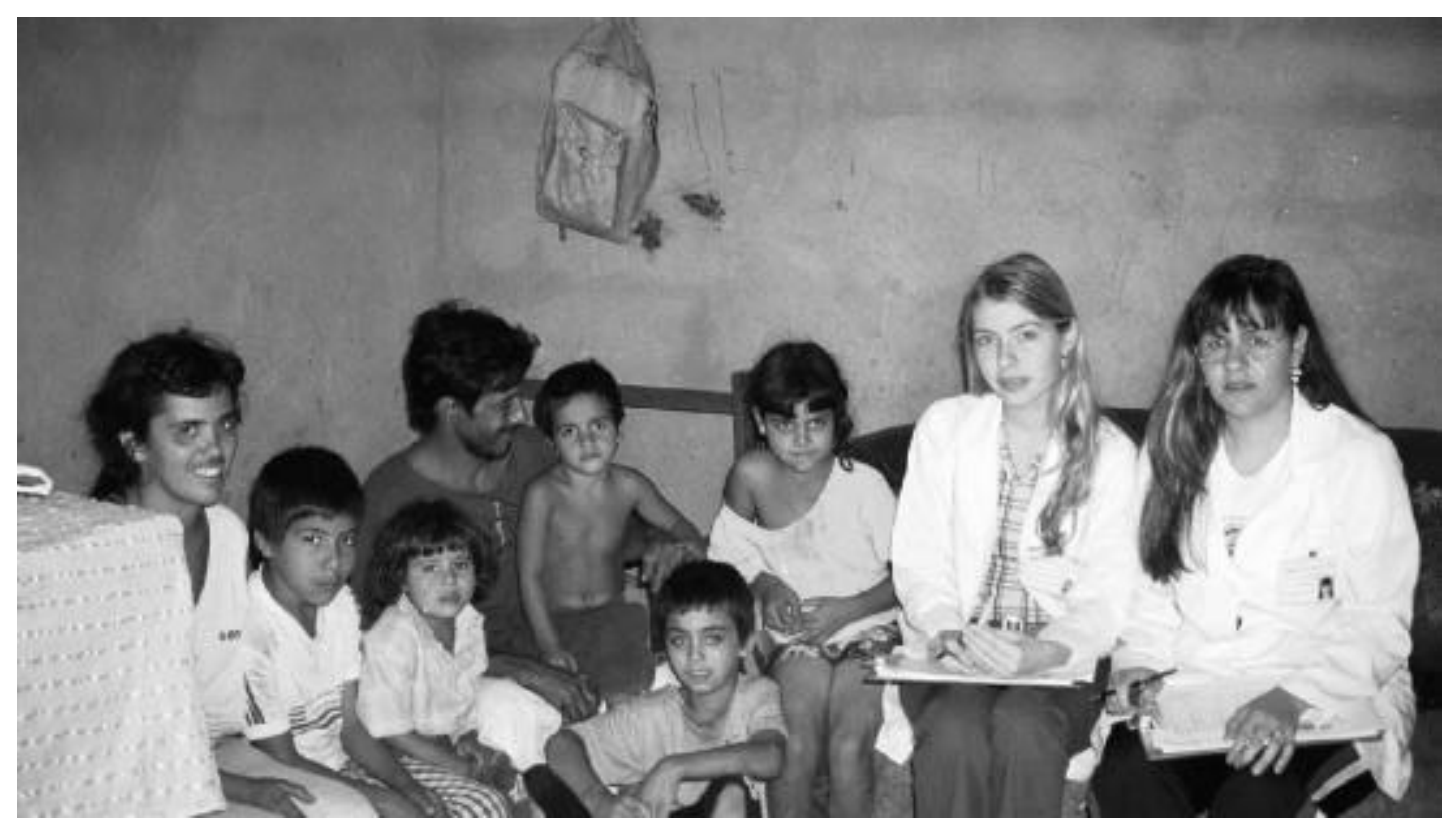

Figura 1 - Alunos realizando o cadastramento das famílias.

\section{b) Segunda Etapa: $3^{\circ}$ período do Curso de Odontologia:}

A partir de fevereiro de 2000, o Projeto Saúde e Cidadania obteve continuidade, junto aos alunos do $3^{\circ}$ período, através da disciplina Odontologia Coletiva II, promovendo ações em saúde bucal e aplicando medidas preventivas para evitar as principais doenças bucais, atuando junto a 1.200 escolares matriculados no $1^{\circ}$ grau do ensino fundamental público, de $1^{\mathrm{a}}$ a $8^{\mathrm{a}}$ série, no período diurno, da Escola Estadual do Bairro Jardim das Palmeiras, situada na periferia do município de Uberlândia.

O Programa desta disciplina envolve o estudo da epidemiologia, etiologia, diagnóstico e prevenção das principais doenças da cavidade bucal, da programação em Odontologia Coletiva, da educação em saúde e da aplicação de métodos preventivos da cárie e da doença periodontal. 
Inicialmente, o aluno conhece a realidade sócio-cultural, econômica e organizacional de uma Escola Pública de Ensino Fundamental, através de um diagnóstico institucional, utilizando um roteiro pré estabelecido. Em seguida, os alunos subdivididos em duplas, recebem como responsabilidade, para o semestre, aproximadamente 40 alunos de uma sala de aula, incumbindo-se de cuidar destas crianças, sob a perspectiva de mantê-las em saúde bucal e evitar que lesões de cárie dental iniciais progridam. Utilizam a evidenciação de placa bacteriana, a orientação para higienização bucal (escovação dentária e uso do fio dental) e a fluorterapia, através da técnica com utilização de moldeiras descartáveis, com a escova de dentes e bochechos, conforme o risco de cárie e doença periodontal de cada criança. Todos estes procedimentos são registrados e acompanhados semanalmente pelas professoras responsáveis pela disciplina, em uma "Ficha do registro do Programa Preventivo".

Para conseguir esta vigilância a saúde bucal da criança, o aluno inicia suas atividades, dentro da referida escola, pela sua apresentação em sala de aula, explicando as crianças de sua responsabilidade, as atividades preventivas que serão realizadas, semanalmente, com as mesmas e o seu compromisso durante o semestre. Neste momento, o aluno entrega para as crianças um comunicado para os pais, informando sobre a importância de sua atuação.

Para traçar um programa preventivo, baseado em higienização bucal, fluorterapia e educação em saúde, conforme o risco de cárie e doença periodontal de cada criança, os alunos do curso de odontologia classificam cada criança em risco de adoecer baixo, médio ou alto, e a partir desta classificação, utiliza o programa preventivo preestabelecido pela disciplina Odontologia Coletiva 11, o qual foi 
adaptado do Programa elaborado pela Secretaria Estadual de Saúde do Estado de São Paulo. (SÃO PAULO, 2001). Conforme demonstrado na Tabela 2 e Quadro 1.

Tabela 2 - Classes de risco de cárie dentária e critérios de agrupamento, segundo a situação individual

\begin{tabular}{|c|c|c|}
\hline Classificação & Grupo & Situação individual \\
\hline $\begin{array}{l}\text { Baixo risco } \\
\text { (1) }\end{array}$ & A & $\begin{array}{l}\text { Ausência de lesão de cárie, sem placa, sem gengivite e/ou sem } \\
\text { mancha branca ativa. }\end{array}$ \\
\hline \multirow{2}{*}{$\begin{array}{l}\text { Risco Moderado } \\
\text { (2) }\end{array}$} & $\mathrm{B}$ & $\begin{array}{l}\text { História de dente restaurado, sem placa, sem gengivite e/ou sem } \\
\text { mancha branca ativa. }\end{array}$ \\
\hline & $\mathrm{C}$ & $\begin{array}{l}\text { Uma ou mais cavidades em situação de lesão de cárie crônica, mas } \\
\text { sem placa, sem gengivite e/ou sem mancha branca ativa. }\end{array}$ \\
\hline \multirow{3}{*}{$\begin{array}{l}\text { Alto risco } \\
\text { (3) }\end{array}$} & $\mathrm{D}$ & $\begin{array}{l}\text { Ausência de lesão de cárie ou presença de dente restaurado, mas } \\
\text { com presença de placa, de gengivite e/ou cálculo e/ou de mancha } \\
\text { branca ativa. }\end{array}$ \\
\hline & $\mathrm{E}$ & Uma ou mais cavidades em situação de lesão de cárie aguda. \\
\hline & $\mathrm{F}$ & Presença de dor e/ou abscesso. \\
\hline
\end{tabular}

FONTE: Adaptado da Secretária Estadual de Saúde de SP.

Quadro 1 - Ações em saúde bucal conforme o risco

\begin{tabular}{|c|c|c|c|c|c|c|}
\hline \multirow{3}{*}{ RISCO } & \multicolumn{6}{|c|}{ RISCO DE CÁRIE* } \\
\hline & \multicolumn{2}{|c|}{1} & \multicolumn{2}{|c|}{2} & \multicolumn{2}{|c|}{3} \\
\hline & $\mathbf{A}$ & B & $\mathbf{C}$ & $\mathbf{D}$ & $\mathbf{E}$ & $\mathbf{F}$ \\
\hline \multicolumn{7}{|l|}{ Educação em Saúde } \\
\hline \multicolumn{7}{|l|}{ Escova. Supervisionada } \\
\hline \multicolumn{7}{|c|}{ Aplicação Tópica de Flúor (Anual) } \\
\hline \multicolumn{7}{|c|}{ Aplicação Tópica de Flúor (Seriada) } \\
\hline \multicolumn{7}{|l|}{ Prioridade $1 \mathrm{p} /$ tratamento } \\
\hline \multicolumn{7}{|l|}{ Prioridade $2 \mathrm{p} /$ tratamento } \\
\hline \multicolumn{7}{|l|}{ Prioridade $3 \mathrm{p} /$ tratamento } \\
\hline \multicolumn{7}{|l|}{ Retorno Anual } \\
\hline \multicolumn{7}{|l|}{ Retorno 8 meses } \\
\hline Retorno 4 meses & & & & & & \\
\hline
\end{tabular}

FONTE: Adaptado da Secretária Estadual de Saúde de SP.

* 1: baixo risco; 2: risco moderado; 3: alto risco

Além das atividades preventivas citadas, que os alunos aplicam junto a estas crianças, os alunos, também, aprendem a realizar o levantamento epidemiológico da 
cárie dental, em crianças de 6 a 14 anos, através do índice odontológico CPO - D inovado (Pinto, 2000). Realizam o Índice de Higiene Oral de Podshadley e Haley das crianças de forma comparativa, considerando o índice encontrado no início e no término das atividades práticas preventivas e educativas desenvolvidas, que coincide com o início e término do semestre letivo.

Ainda nesta etapa do projeto os alunos desenvolvem um importante trabalho educativo, voltado para cidadania e saúde com as crianças, utilizando técnicas com linguagem apropriada, objetiva, criativa e acessível, sobre a etiologia e prevenção das principais doenças bucais e temas escolhidos pelas crianças, incorporando novos conceitos no sentido da manutenção e criação de hábitos saudáveis e mudança de hábitos nocivos à saúde.

Esta etapa do projeto promove, estimula e reforça o comportamento solidário e criativo do aluno do curso de odontologia, além de instrumentá-lo para adoção de medidas preventivas baseadas em programas de higienização e fluorterapia.

No $3^{\circ}$ período, o conteúdo programático desta disciplina envolve o estudo da epidemiologia das principais doenças bucais, da programação em Odontologia Coletiva, da educação para cidadania e saúde, e em como utilizar os métodos preventivos da cárie e da doença periodontal em abordagens coletivas. Os seus objetivos educacionais são:

- Promover a integração do aluno com a comunidade escolar, socialmente desfavorecida, de ensino fundamental, dinamizando o ensino dos aspectos preventivos, educativos e sociais das principais doenças bucais; 
- Proporcionar ao aluno a vivência com as práticas de odontologia coletiva e dos processos sociais em que profissionais da equipe odontológica e usuários do sistema público de saúde - SUS (Sistema Único de Saúde) estão inseridos, colocando o mais precocemente possível, na prática e “in loco” com as condições reais de saúde bucal da infância brasileira;

- Identificar a realidade social, econômica, cultural e organizacional das duas escolas públicas de ensino fundamental;

- Realizar levantamento epidemiológico da cárie dental em crianças de 6 a 14 anos, através do índice odontológico CPO-D (cariados, perdidos e obturados - dente) inovado;

- Utilizar os métodos de higienização supervisionada e a prevenção da cárie e doença periodontal em abordagem individual e coletiva, adotando diferentes técnicas de aplicação tópica de flúor;

- Realizar levantamento do Índice de Higiene Oral das crianças da escola;

- Realizar avaliação do risco de cárie e doença periodontal das crianças;

- Promover educação para cidadania e saúde com as crianças;

- Promover, estimular e reforçar o comportamento criativo do aluno.

A figura 2 demonstra os estudantes de odontologia na realização da atividade de ensino referente à interação com os pais, dos alunos da Escola do Bairro Jardim das Palmeiras, sobre a avaliação de risco individual de seu (s) filho(s), assim como o comportamento do mesmo frente ao Programa de Prevenção estabelecido pelo Projeto. Uberlândia, 2000. 


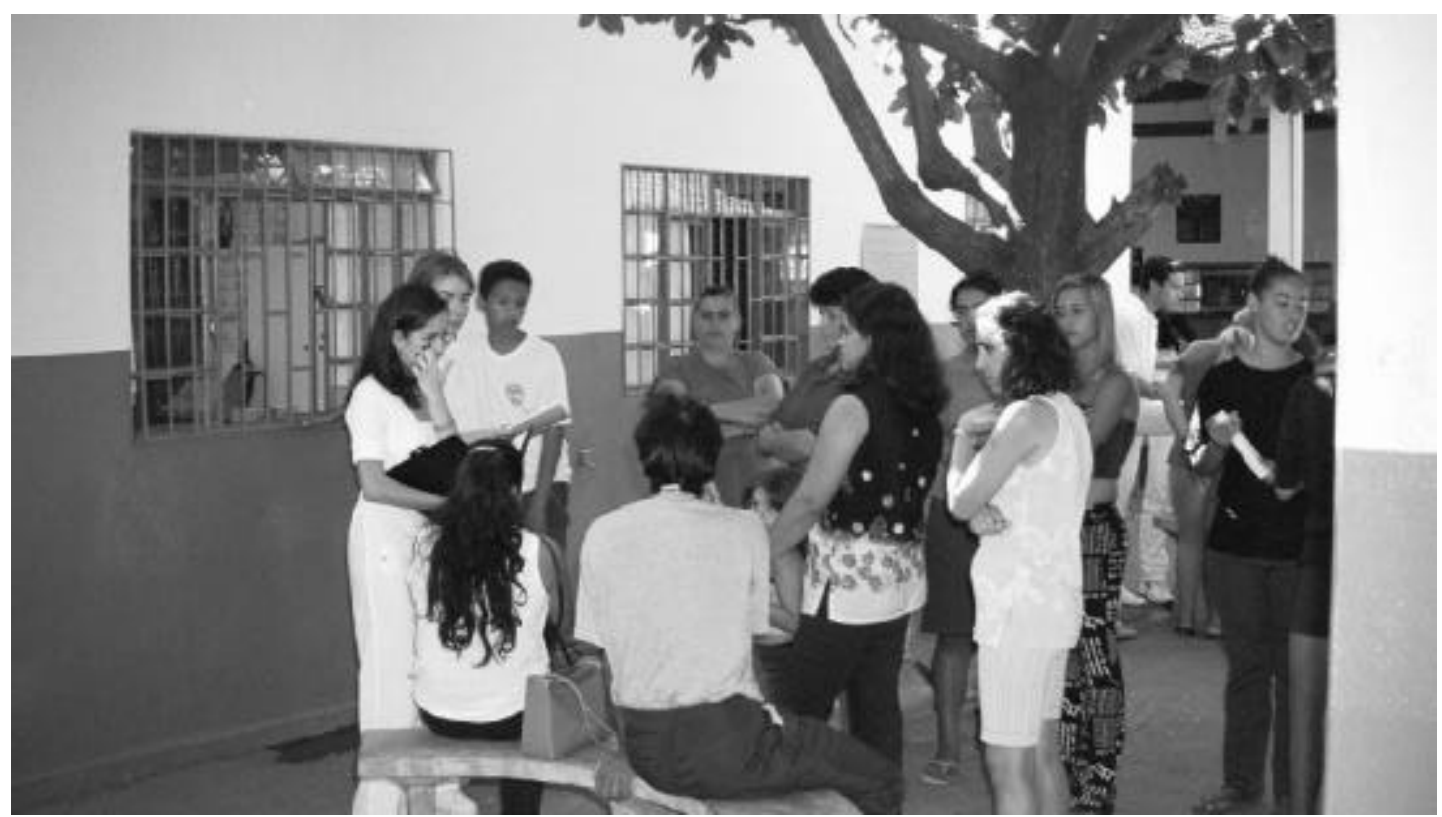

Figura 2 - Estudantes de odontologia em atividades de interação com pais de alunos da E. E. Jardim das Palmeiras.

\section{c) Terceira Etapa: $4^{\circ}$ período do Curso de Odontologia}

No $4^{\circ}$ e $5^{\circ}$ períodos, as disciplinas denominadas Orientação Profissional 1 e 11 , respectivamente, abordam o conteúdo referente aos recursos humanos necessários em odontologia, a biossegurança, a ergonomia e como inserir a odontologia na estratégia de saúde da família situados no contexto político, econômico e sócio cultural brasileiro.

O aluno aplica os conhecimentos adquiridos em aula teórica, realizando levantamentos epidemiológicos e medidas de promoção em saúde bucal, no domicílio.

Esta etapa do projeto prepara os alunos para que desenvolvam uma odontologia dentro dos princípios de biossegurança, conheçam os equipamentos a serem utilizados para montagem dos consultórios, procurando diminuir os movimentos e o tempo no tratamento odontológico. O aluno identifica os riscos ocupacionais e aprende como se prevenir de forma adequada, sendo que conjuntamente, promove a 
integração das ações de promoção em saúde na comunidade, através das visitas domiciliares.

As atividades práticas, desta etapa do projeto, subdividem-se nos seguintes items:

- Visita e identificação das famílias a serem trabalhadas;

- Cadastros familiares, conforme ficha preconizada pelo Ministério da saúde para o PSF;

- Cadastro de saúde bucal

- Classificação dos componentes da família através da avaliação visual do risco às doenças bucais;

- Avaliação das condições das escovas dentais e uso de fio dental;

- Evidenciação de Placa Bacteriana com solução de boca roxa e coleta do Índice de Higiene Oral (IHO) em 10 integrantes das famílias cadastradas; sendo que o índice de placa deve ser colhido ao final do semestre para avaliar o desempenho das atividades educativas.

- Levantamento epidemiológico da cárie dental, nos mesmos 10 integrantes da família, através da utilização do índice odontológico - (CPO-D inovado);

- Higiene Bucal Supervisionada (HBS);

- Bochechos fluorados, conforme o risco e

- Trabalhos de Educação em Saúde com a família.

Os objetivos educacionais do ciclo prático desta disciplina são:

- Despertar o aluno de odontologia para a importância de adotar o enfoque da saúde da família e da promoção em saúde;

- Realizar levantamentos epidemiológicos no domicílio. 
A figura 3 demonstra os estudantes de odontologia na realização da visita domiciliar para aplicação do Programa Preventivo estabelecido pelo Projeto, junto aos membros da família. Uberlândia, 2001.

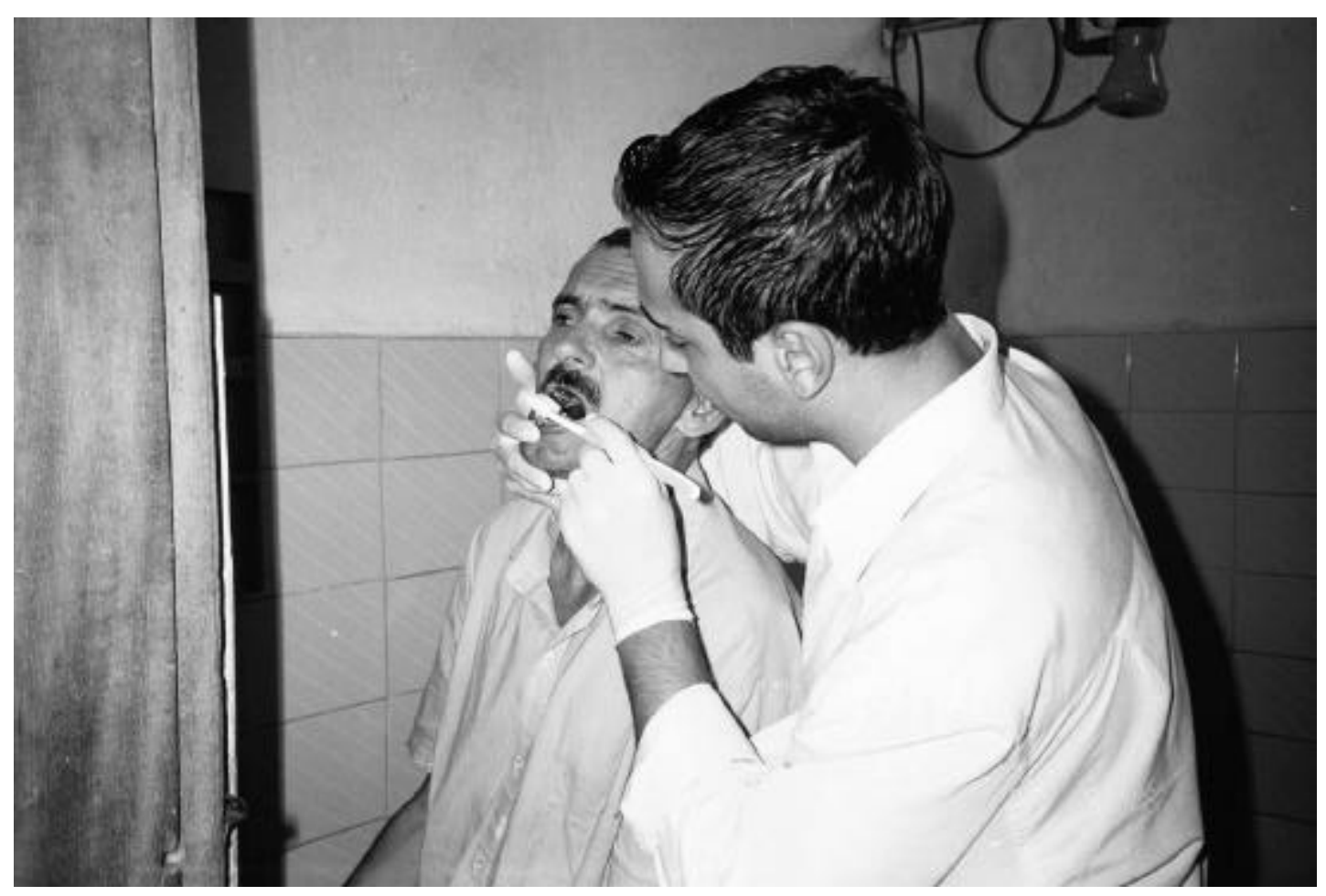

Figura 3 - Realização das atividades junto aos membros da família.

\section{d) Quarta Etapa: $5^{\circ}$ período do Curso de Odontologia:}

As atividades visando a saúde bucal coletiva continuam no $5^{\circ}$ período, ocorrendo a integração do aluno de Odontologia, com as crianças menores de seis anos, integrando ações de promoção em saúde na comunidade e em creches públicas, com o trabalho, voltado para a promoção em saúde na Creche Lar Alfredo Júlio.

As atividades práticas são realizadas com crianças que freqüentam a creche, na qual o aluno aplica os conhecimentos adquiridos, levantamentos epidemiológicos e medidas de promoção em saúde bucal, com crianças menores de seis anos. 
A disciplina orientação profissional II tem como objetivos específicos, que o aluno:

- Tenha noções gerais de direito e sua importância para o cirurgião dentista;

- Saiba guardar segredo profissional;

- Saiba receitar e atestar dentro dos preceitos legais;

- Trabalhe dentro da moral e da ética, no atendimento ao paciente;

- Saiba exercitar a profissão de forma lícita;

A fim de aplicar os conhecimentos adquiridos, o aluno realiza atividades preventivas, educativas de Promoção em Saúde, com crianças de creches. Esta quarta etapa do projeto subdivide-se nas seguintes atividades:

- Visita e identificação das crianças com necessidades de tratamento;

- Classificação das crianças quanto ao risco de cárie para desenvolvimento das atividades preventivo-educativas;

- Avaliação das condições das escovas dentais e uso de fio dental;

- Orientar as funcionárias da creche, quanto aos aspectos ligados a ingestão de alimentos açucarados-escovação dos dentes-risco de cárie;

- Higiene Bucal Supervisionada (HBS);

- Realizar levantamento epidemiológico da cárie dental, através da utilização do índice odontológico - CPOD e

- Realizar trabalhos de educação em saúde.

O objetivo educacional desta disciplina é realizar atividades preventivas e educativas de Promoção em Saúde, com crianças matriculadas na creche, enfatizando os preceitos da moral, dos direitos e da ética no atendimento ao ser humano. 
A figura 4 demonstra os estudantes de odontologia na realização das atividades de ensino na Creche Lar Alfredo Júlio. Uberlândia, 2001.

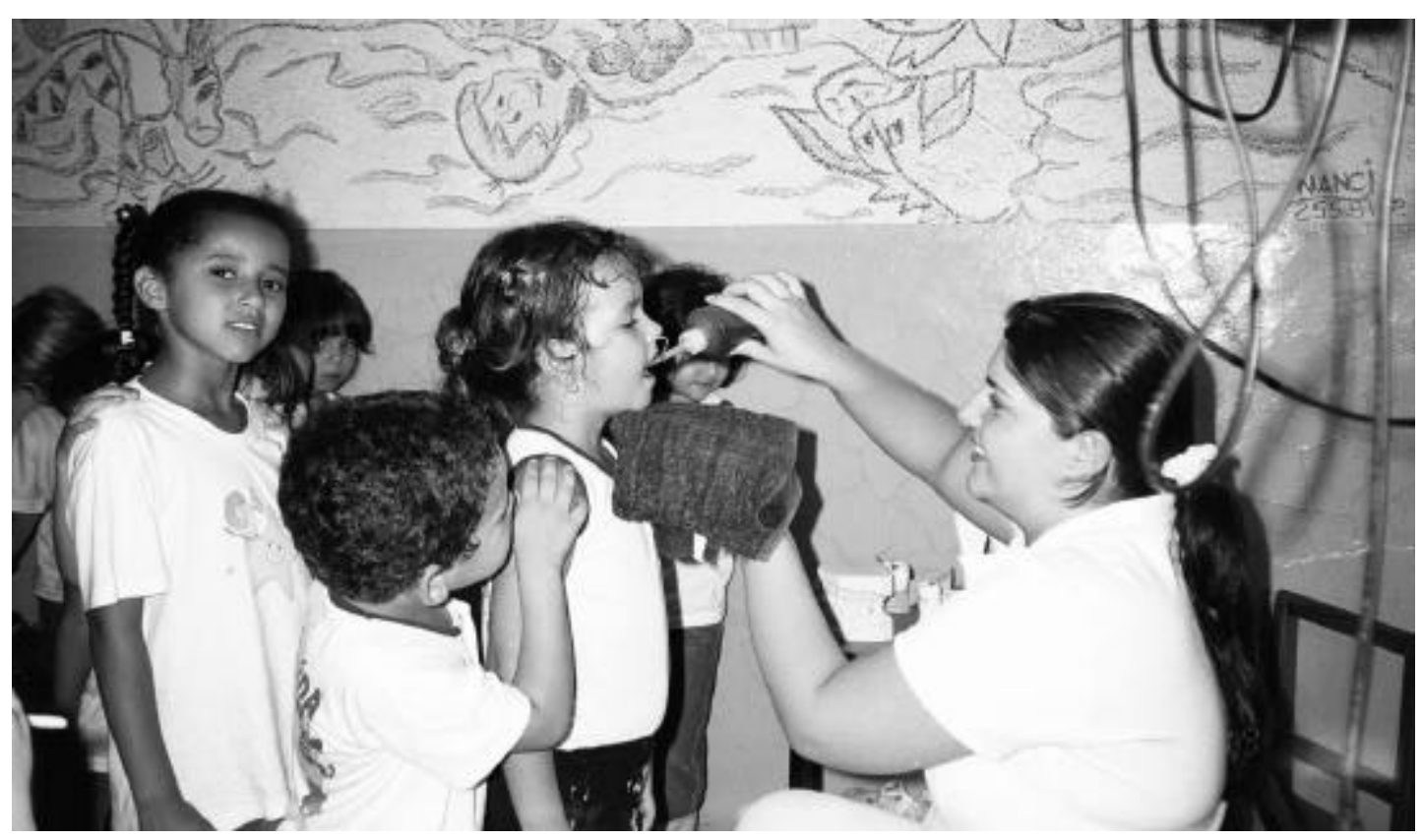

Figura 4 - Atividades preventivas realizadas na Creche Lar Alfredo Júlio.

\section{e) Quinta Etapa: $7^{\circ}$ e $8^{\circ}$ períodos do Curso de Odontologia:}

Nesta última etapa, desenvolvida durante os $7^{\circ}$ e $8^{\circ}$ períodos, nas disciplinas Programa Odontológico Coletivo 1 e 1l, os alunos iniciam os atendimentos clínicos e restauradores, junto às crianças em idade escolar, dando continuidade, ao trabalho desenvolvido, pelos alunos do $2^{\circ}$ período do curso de odontologia, nas Escolas Estadual do Bairro Jardim das Palmeiras e a partir de 2002, também, na Escola Estadual do Anexo Shopping Park.

A elaboração desta etapa do projeto parte da compreensão da importância da preparação do aluno para atuar no âmbito do SUS. Através da parceria acordada entre a UNIT e a Prefeitura Municipal de Uberlândia, representada pela sua 
Secretaria de Saúde, viabilizou aos alunos do $7^{\circ}$ e $8^{\circ}$ períodos a participação ativa nas ações preconizadas para a equipe de saúde bucal do Programa Odontológico de atenção a crianças em idade escolar, em suas fases de planejamento, promoção, prevenção, recuperação e manutenção da saúde bucal.

Nesta parceria que tem como finalidade o atendimento preventivo, clínico e restaurador das crianças da escola pública supracitada, o município através do SUS fornece o material de consumo odontológico.

Desta forma, ao final do ano de 2002 complementarar-se-á o ciclo da organização das ações de saúde bucal na atenção básica para as 1300 crianças matriculadas no ensino fundamental das Escolas supracitadas, considerando que os alunos do $2^{\circ}$ período responsabilizam-se, desde o ano de 2000, pela atenção primária básica de natureza coletiva.

\section{As disciplinas tem como objetivos principais:}

- Instrumentalizar o aluno para o desenvolvimento de planejamentos e avaliação em serviços de saúde coletiva;

- Implantar o uso regular de instrumentos que avaliem os padrões de qualidade e o impacto das ações desenvolvidas;

- Definir as estratégias específicas ao desenvolvimento das ações de saúde e

- Realizar procedimentos clínicos restauradores, cirúrgicos, de pronto atendimento e educativos e preventivos.

\section{Planejamento e Execução das Ações do $7^{\circ}$ e $8^{\circ}$ períodos}

A abordagem da população-alvo na Escola Estadual do Bairro Jardim das Palmeiras, quanto às ações odontológicas é planejada segundo o contexto local do 
perfil epidemiológico dos escolares. Este enfoque considera três objetivos a serem atingidos concomitantemente:

(1) Interromper a livre progressão da doença nos escolares, evitando o surgimento de casos novos (diminuir incidência ou incremento);

(2) Detectar lesões e sinais reversíveis mediante diagnóstico precoce e empregar tecnologias não cirúrgicas (diminuir prevalência);

(3) Reabilitar, através de procedimentos cirúrgico-restauradores, os doentes e/ou portadores de sequielas, tanto em atenção primária como secundária, através de um sistema de referência e contra-referência eficiente, considerando a possibilidade de incluir a oferta de serviços disponíveis nas Clínicas do Curso de Odontologia da UNIT.

Atingir tais objetivos implica em utilizar rotineiramente recursos epidemiológicos e desenvolver ações assistenciais e de promoção de saúde inseridas em sistemas de referência e contra-referência.

As ações de maior complexidade, que pressupõem a utilização de equipamentos, insumos e recursos humanos especializados, são encaminhadas para as clínicas integradas e especializadas, da clínica integrada da UNIT.

Cabe aos alunos analisarem o perfil de saúde bucal dos escolares e elaborarem seu roteiro de ação de forma a atender gradativamente todos os grupos de escolares. Conforme a classificação do risco é obtido um grupo de prioridades, que direcionarão tanto as ações de cunho individual quanto as de cunho coletivo. Isto significa que, todos devem receber educação em saúde bucal e ter garantido o acesso ao diagnóstico e à prevenção e controle da doença e da dor, através de ações coletivas e individuais. 
É adotado como estratégia o Controle Epidemiológico da Cárie Dentária (CEC) a adequação do meio bucal ou a técnica de restauração atraumática, com eliminação de focos, para dar cobertura a toda a população da escola e, num momento posterior, quando toda a população já estiver em situação de controle, passar à assistência individual cirúrgico-restauradora, de acordo com as considerações abaixo.

\section{Controle Epidemiológico da Cárie (CEC):}

Esse caminho, embora proposto pela Secretaria Estadual de Saúde de São Paulo desde 1989, ainda é novo para a maioria dos profissionais e a resistência a essa metodologia de trabalho não vem apenas da formação, mas também pelo acúmulo dessa prática no decorrer dos anos de trabalho. Mas é preciso estar aberto a proposições inovadoras, pois o modelo de prática hegemônico no país não foi capaz de trazer melhores níveis de saúde bucal para a maioria da população.

Assim, reproduzimos em seguida esta pertinente proposta da Secretaria de Estado da Saúde de São Paulo, que foi adotada pelo Projeto de Saúde Bucal Coletiva:

"Diante do desafio da implementação prática das conquistas legais, torna-se imperativo recorrer-se a metodologias que contemplem alta cobertura e propor medidas que priorizem a distribuição dos recursos de uma forma equânime, através da utilização de critérios de risco às doenças bucais mais prevalentes, possibilitando identificar parcelas da população que necessitam de cuidados prioritariamente. Devido a falta de acesso histórico à saúde bucal, os problemas acumulados são tão expressivos que inviabilizam o acesso até mesmo dos priorizados dentro das triagens para realização de tratamentos clínicos de imediato. Se não é possível efetuar-se a assistência individual com tratamentos completados a todos os que dela precisam imediatamente, em conseqüência das limitações impostas pelos recursos humanos e financeiros, também não é justo realizar procedimentos mais sofisticados em alguns, enquanto a maioria não tem acesso aos procedimentos básicos." (SÃO PAULO, 2001) 
Embora mais recursos possam ser necessários, será que não é possível a otimização do já existente, através de um planejamento eficiente e eficaz baseado na epidemiologia, em tecnologias inovadoras e no conhecimento científico do processo saúde-doença? Surge, portanto, nesse cenário, a proposta desta última fase do projeto de realização dos tratamentos em duas fases.

$\mathrm{Na}$ primeira fase a proposta indica realizar o Controle Epidemiológico da Cárie (CEC) que nada mais é que a "adequação de meio", com remoção de focos e selamento de cavidades de todos as crianças presentes na sala de aula de responsabilidade da dupla de alunos.

A segunda fase que contemplaria os procedimentos restauradores com materiais definitivos é iniciada apenas quando todas as crianças classificadas e autorizadas para o atendimento tiverem tido acesso à $1 .^{\mathrm{a}}$ fase.

Trata-se de uma organização de demanda que possibilita uma extensão de cobertura rápida, evitando que os problemas se agravem no decorrer da espera para o tratamento.

Essa metodologia possibilita inclusive a interrupção da história natural da doença, através de procedimentos básicos, associados a medidas educativas e preventivas com o acompanhamento pelos alunos do $2^{\circ}$ período.

Levando-se em conta a simplicidade dos procedimentos propostos na 1. ${ }^{\mathrm{a}}$ fase, permite-se uma maior agilidade e rotatividade das crianças a serem atendidos, que automaticamente ao término dos procedimentos iniciais ( $1^{\mathrm{a}}$ fase) passarão para uma fase de acompanhamento e controle da doença na escola, atividade essa que deverá ser realizada prioritariamente pelos alunos do $2^{\circ}$ período, na disciplina Odontologia Coletiva II. 
A odontologia tem por excelência a perfeição das restaurações em amálgama, resina e reconstruções lindíssimas. Porém, a questão social no momento é mais urgente. A remoção de focos de infecção e dor, que permeiam crianças é fundamental e não pode ser relegado a segundo plano. Há tempo para tudo e o pensamento inicial é o de conseguir melhor nível de saúde bucal para o conjunto das crianças matriculadas na escola, para, posteriormente, de forma progressiva, complementar-se o tratamento com restaurações definitivas e atividades de maior complexidade“.

Para que se trabalhe dentro do princípio de eqüidade, garantindo atenção privilegiada onde e para quem ela se verifique necessária, aos dados da Ficha de Triagem para Avaliação do Risco, em Anexo D, são somadas informações epidemiológicas dos escolares. Nesse sentido, é primordial que se conheça a epidemiologia dos processos de saúde/doença bucal na Escola Jardim das Palmeiras.

Deste modo, os alunos completam o ciclo de atenção a comunidade envolvida no Projeto, realizando o atendimento clínico restaurador das crianças e adolescentes em idade escolar, que recebem atenção preventiva e educativa, através dos alunos que cursam os outros períodos que dão suporte ao Projeto, tendo como conteúdo programático o planejamento a execução e a avaliação de serviços de saúde bucal coletiva. Estas disciplinas têm como objetivos educacionais:

- Complementar a atenção em saúde bucal, aos alunos da Escola Estadual do Bairro Jardim das Palmeiras e Escola Municipal Olga D’el Fávero, desenvolvendo o planejamento e avaliação conforme o risco individual de cárie, doença periodontal e tecidos moles, executando as ações clínicas 
restauradoras, cirúrgicas e de pronto atendimento, na busca da garantia do direito à saúde estabelecido na Constituição;

- Instrumentalizar o aluno para o desenvolvimento de planejamentos e avaliação em serviços de saúde bucal coletiva;

- Implantar o uso regular de instrumentos que avaliem os padrões de qualidade e o impacto das ações desenvolvidas;

- Definir as estratégias específicas ao desenvolvimento das ações de saúde;

- Realizar procedimentos clínicos restauradores, cirúrgicos, pronto atendimento e educativos preventivos.

A figura 5 demonstra os estudantes de odontologia na realização das atividades clínicas restauradoras, junto às crianças triadas da Escola do Bairro Jardim das Palmeiras. Uberlândia, 2001.

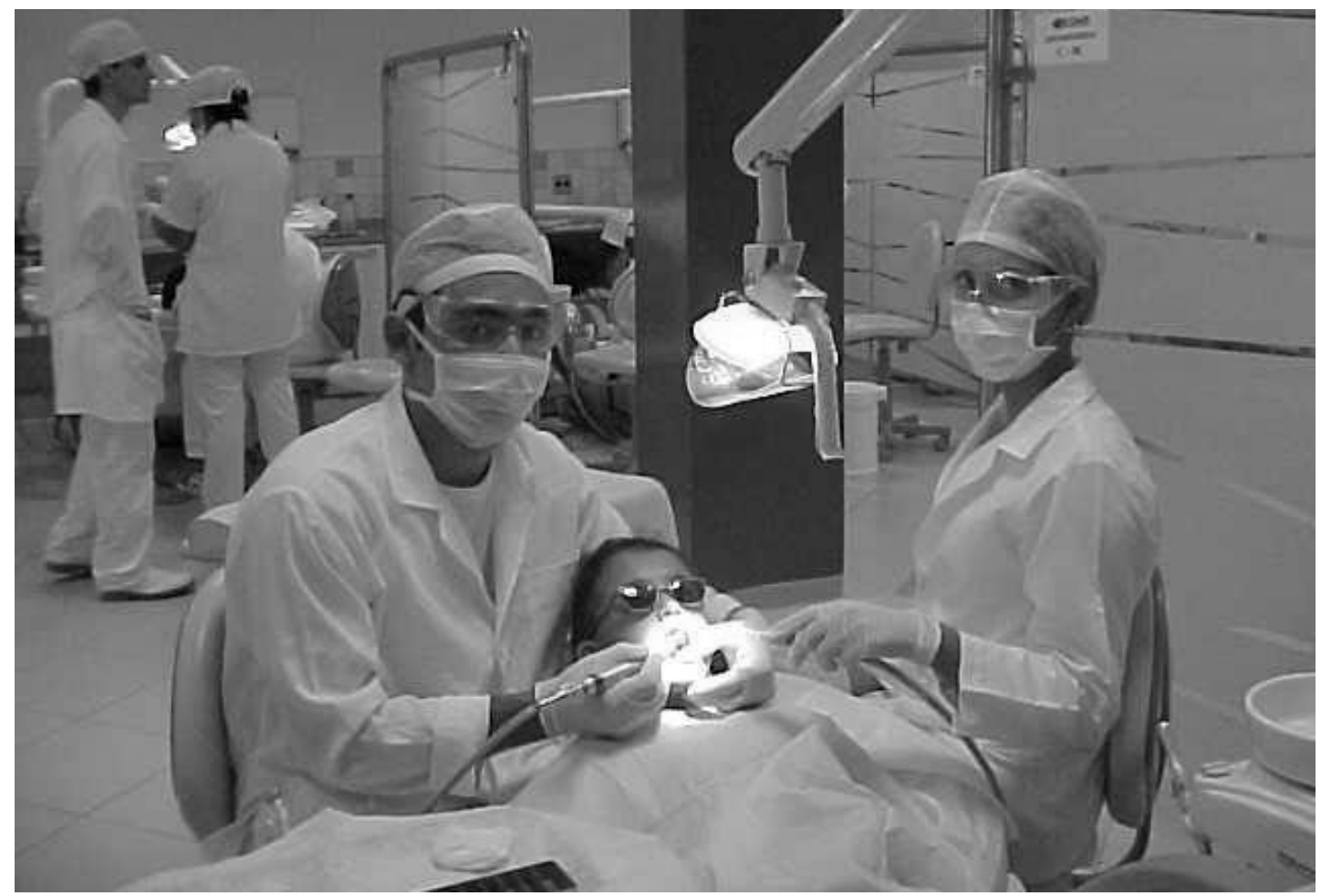

Figura 5 - Atividades clínico-restauradoras. 
Desta forma, a partir da perspectiva de uma educação que associasse a compreensão dos conteúdos desenvolvidos pelas disciplinas Odontologia Coletiva I Programa de Saúde da Família, Ciências Sociais aplicadas à Saúde, Odontologia Coletiva II, Orientação Profissional I e II, Programas Odontológicos Coletivos I e II e a vivência de uma práxis efetiva, junto à população atendida nos serviços básicos de saúde pública, foi concretizado os objetivos educacionais citados, através deste Projeto Saúde Bucal Coletiva, junto aos alunos do primeiro ao quarto ano do Curso de Odontologia, do referido Centro Universitário.

\subsection{OBJETIVOS}

\subsubsection{Objetivo Geral}

Analisar a contribuição do Projeto Pedagógico de Saúde Bucal Coletiva Saúde e Cidadania, m formação do estudante do Curso de Odontologia, do Centro Universitário do Triângulo, em Uberlândia, Minas Gerais, na perspectiva dos princípios do Sistema Único de Saúde, da promoção em saúde bucal e da atenção em saúde da família.

\subsubsection{Objetivos Específicos}

- Identificar o perfil social do estudante de odontologia e suas expectativas frente ao Projeto Saúde Bucal Coletiva - Saúde e Cidadania;

- Caracterizar o Projeto Saúde Bucal Coletiva em sua concepção teórica e nos seus aspectos pedagógicos e operacionais, identificando suas potencialidades 
e limitações, na formação do estudante de odontologia, segundo a ótica dos mesmos;

- Identificar a concepção do aluno em relação à alguns dos conteúdos básicos do Projeto Saúde Bucal Coletiva (papel do odontólogo no Sistema Único de Saúde, os princípios do SUS e da atenção em saúde da família, condições de vida e saúde bucal das crianças e das famílias atendidas). 


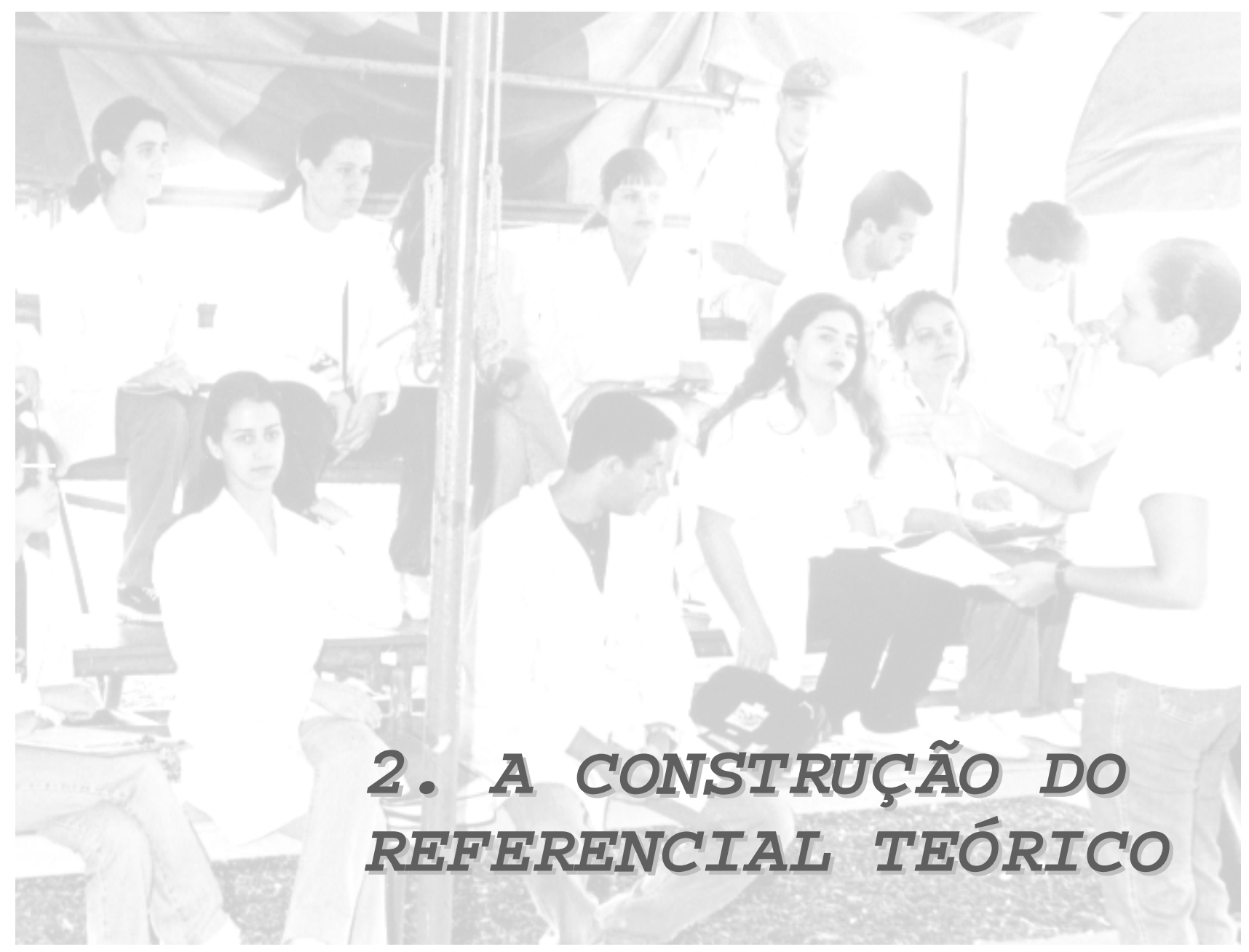




\section{APONTANDO PARA A NECESSIDADE DE REPENSAR O PROCESSO DE ENSINO- APRENDIZAGEM NA ODONTOLOGIA E AS CONCEPÇÕES QUE EMBASAM A SAÚDE} BUCAL COLETIVA NA UN IVERSIDADE

É necessário que o pesquisador saiba que existem diferentes lógicas de ação em pesquisa e que o importante é manter-se coerentemente dentro de cada uma delas. Silva (1998) menciona que, além disso, é necessário que o pesquisador saiba explicitar em seu relato de pesquisa a sua opção metodológica e todo procedimento desenvolvido na construção de sua investigação e os quadros de referência que o informam.

Compreendemos que os quadros de referência constituem-se conforme coloca Bruijne et al. (1991);

"Uma espécie de matriz disciplinar que agrupa um conjunto de paradigmas... Pode tratar-se de protocolos informais que freqüentemente não tomam forma de regras explícitas, mas que nem por isso deixam de condicionar e de orientar toda prática teórica ou mesmo o trabalho de pesquisa em sua totalidade."

O presente trabalho insere-se no campo da construção da saúde bucal coletiva na universidade, investigando estratégias de ensino - aprendizagem, presentes no Projeto Saúde Bucal Coletiva - Saúde e Cidadania. Enfocamos a preocupação em preparar o aluno de graduação em odontologia engajado com a realidade social, a política oficial de saúde - o Sistema Único de Saúde - e capacitá-lo para desenvolver uma postura preventiva e atuar em abordagens de alcance coletivo, inclusive a estratégia de saúde da família. 
O interesse na investigação desta problemática origina-se da situação sanitária posta hoje no país, devido a uma política econômica de concentração de renda, onde, conforme explicita (PINTO, apud BOTAZZO e FREITAS, 1981).

“... somente $4 \%$ da população, ou seja, aqueles que ganham acima de 10 salários mínimos, têm acesso à clínica particular. Para o restante da população, a Odontologia oferece resposta mutilatória, ou seja, a extração... apresentada como a” prevenção de mal menor “... Para as classes populares, a representação do dente é a dor... a solução para a dor é a extração. Deve-se ressaltar que esta solução não é dirig ida ao problema em si (cárie, periodonto), mas à sua manifestação (dor) sendo, portanto uma alternativa que não recupera a saúde e sim a agrava..."

"Não há como esconder. Está na cara. É tão grave a situação no país que a cárie e as doenças de gengiva são consideradas endemias. O pior sorriso do mundo, o mais desalinhado, é o do Brasil". (Jornal da UNESP, 1994).

Assim, este trabalho tem em sua gênese a proposta de exploração de alternativas na formação de cirurgiões dentistas para a alteração deste quadro, ante uma sociedade que gera doenças e não possibilita a saúde e diante de profissionais que, muitas vezes, buscando a saúde provocam doenças e não se sentem responsáveis para alterar e transformar esta realidade. Buscamos formar profissionais capazes de ultrapassar os limites estreitos de sua atividade prática para percebê-la, sobretudo, em algumas de suas formas, o trabalho, a atividade política, a divisão de classes sociais, enfim em toda a sua dimensão antropológica, econômico, e sócio-cultural.

Precisamos colocar, neste momento de explicitação dos quadros de referência, que informam os suportes teóricos, que iremos investigar as questões pedagógicas que permeiam os nossos tema. Alguns referenciais pedagógicos básicos serão abordados, pois, torna-se necessário tocar na inadequação da metodologia pedagógica tradicional predominante, no momento atual da política educacional, 
analisando as mudanças no mundo do trabalho e da reforma curricular dos cursos de graduação no Brasil.

Assim um suporte teórico que se inscreve como essencial em nossa pesquisa refere-se ao ideário UNI - Uma Nova Iniciativa na Educação dos Profissionais de Saúde: União com a Comunidade, construído com base numa análise crítica das experiências anteriores de integração docente-assistencial desenvolvidas na América Latina. Este ideário, lançado em 1991, teve como ponto de partida o contexto e o processo de construção da democracia, as principais propostas de organização dos sistemas de saúde e as idéias vigentes no movimento de mudança da educação de profissionais de saúde.

A principal idéia deste suportes teóricos que elegemos, inserem-se para um tipo de construção do conhecimento que permeiam a proposta de parceria entre universidade, serviço de saúde e comunidade, em uma modalidade de cogestão do processo de trabalho colaborativo, em que os parceiros compartilham poderes, saberes e recursos.

Baseia-se na constatação de que há uma crise, um esgotamento do paradigma cartesiano que se manifesta em vários terrenos, principalmente no terreno da produção do conhecimento e especificamente do tema em estudo que enfoca as práticas de educação em saúde bucal coletiva.

Defendemos que o novo saber tem de ser construído com base no diálogo entre o saber e o senso comum. Uma universidade mais democrática e com compromissos sociais, a formação de profissionais críticos e com capacidade de aprendizagem independente. Precisamos para este desafio de serviços de saúde 
abertos, trabalhando sobre os problemas relevantes da população e contribuindo para o fortalecimento da participação cidadã.

Então se trata, com certeza, de construir processos profundos de mudanças a médio e longo prazo.

Quanto às concepções da saúde bucal coletiva no ensino da odontologia fundamentamo-nos em alguns autores consagrados da literatura nacional, tais como: Vitor Pinto, Paulo Capel Narvai e Eugênio Villaça Mendes.

Mendes (1984) que antevê o surgimento de uma pedagogia de qualidade diferente, quando no Brasil vinha surgindo nas décadas de 1970 e 1980, movimentos de inovação em educação odontológica, em contraposição a um modelo hegemônico de ensino tradicional, congruente com a ideologia e a prática da odontologia flexneriana, para um modelo inovado, com três elementos básicos: a atitude preventiva, a simplificação e adequação de atos, técnicas, sistemas de trabalho, demais elementos e a desmonopolização do saber, constituintes da odontologia integral;

Narvai (1994) ao analisar a evolução das práticas odontológicas, caracterizando as principais correntes, o momento histórico em que surgiram e os atores sociais que impulsionaram tais projetos até a "saúde bucal coletiva", na defesa de uma odontologia sem adjetivos que, pelo conteúdo de sua prática, afirme relações sociais democráticas.

Pinto (2000) que traduz com fidelidade as transformações ocorridas nesses últimos dez anos com a saúde bucal coletiva e com as ciências que lhe são correlatas, enfocando a emergência do conceito de promoção em saúde, a operacionalização do odontólogo de família e proporcionando uma clareza e cautela ao analisar as 
prováveis causas do declínio da cárie no mundo, para que as atividades de prevenção no presente possam ser mais bem fundamentadas, analisando suas conseqüências para os serviços odontológicos. A sua contribuição é, em nossa opinião, para a história da "odontologia de saúde pública", o que persiste como um ponto de referência, fundamental e imprescindível, para os interessados em abraçar efetivamente a tarefa de promover saúde bucal de nossa gente brasileira.

\subsection{O Suporte Teórico Para olHar o Projeto Saúde Bucal Coletiva}

A Questão do marco conceitual, explicitado por Mendes (1984) e Mendes \& Marcos (1984), pertence ao campo das ideologias, entendidas como conjunto de normas e representações que orientam: “... os pensamentos e as ações, a serviço de grupos sociais sem que, necessariamente, esses grupos, tenham, delas, consciência.”

Assim, o referido autor considera a necessidade de desvendar as "ideologias subjacentes" a certos modos de pensar e fazer educação odontológica e de se estabelecer a sua lógica estrutural. Identifica duas ideologias que determinam o modo de educação odontológica no Brasil: a primeira, hegemônica, define o modo tradicional de educação odontológica - a ideologia cientificista ou flexneriana, e a segunda delineada como contra-ideologia, alternativa, não sendo uma prática destinada a populações marginalizadas, mas um novo modelo, possuindo elementos ideológicos de uma nova concepção de odontologia, incorporando o saber e o fazer ao nível do interesse da coletividade.

Interessa-nos, neste momento, explicitar e comparar os elementos ideológicos destes dois paradigmas da odontologia - o cientificista e o integral - demonstrando a 
importância de resgatar os principais elementos do que se denominou de “odontologia integral”, para a prática e educação odontológica no Brasil e na América Latina.

Tendo em vista, facilitar a compreensão de forma comparativa entre estes dois paradigmas, relacionamos na Tabela 3 a seguir os seus elementos ideológicos ou estruturais.

Tabela 3 - Principais elementos estruturais da odontologia cientificista e da odontologia integral

\begin{tabular}{l}
\hline \hline ODONTOLOGIA C IENTIFICISTA \\
\hline Biologismo : reconhecimento exclusivo da \\
natureza biológica das doenças e de suas \\
causas e consequiências. Exclusão da causa \\
econômica e social.
\end{tabular}

Individualismo: Natureza individual do seu objeto. Imputa ao indivíduo a responsabilidade pela sua própria doença.

Ênfase na odontologia curativa: prestigia diagnóstico e terapêutica (processo fisiopatológico) em detrimento da causa. A cura incorporou mais tecnologia e maior custo.

Mecanicismo e especialização: analogia do corpo com a maquina, em função disto, impôs o fracionamento e aprofundamento do conhecimento específico e atenua o conhecimento holístico.

Exclusão de práticas alternativas: refutação a priori de outros métodos, considerados ineficazes.

Tecnificação do ato odontológico: associação da qualidade à tecnologia de alta sofisticação

\section{ODONTOLOGIA INTEGRAL}

Saúde como questão social:

Reconhecimento da determinação social do processo saúde e doença.

Coletivismo: resgata a característica coletiva do objeto da prática odontológica.

Integração de atividades promocionais, preventivas e curativas: procura recompor a integralidade do ato odontológico, sob a hegemonia do promocional e preventivo.

Holismo: considera o organismo vivo a partir de um todo indecomponível.

Inclusão de práticas alternativas: integrar dialeticamente o discurso popular com o discurso oficial.

Tecnologia apropriada: sem negar a importância de certas tecnologias de alta densidade, valoriza a tecnologia adequada a realidade cultural e social, auto-suficiente e confiável. 
(conclusão)

\begin{tabular}{ll}
\hline \hline ODONTOLOGIA CIENTIFICISTA & ODONTOLOGIA INTEGRAL \\
\hline $\begin{array}{l}\text { Centralização de recursos: hospitais } \\
\text { centrais, atenção urbano-cêntrica. }\end{array}$ & $\begin{array}{l}\text { Descentralização da atenção: } \\
\text { hierarquização em níveis de atenção e } \\
\text { universalização da atenção básica }\end{array}$ \\
Centrada no Profissional isolado & Equipe de saúde: distribuição das funções \\
& odontológicas por diversos tipos de recursos \\
& humanos, profissionais ou da própria \\
& comunidade. \\
& Participação comunitária: comunidade \\
participar ativamente dos processos \\
educacionais e da prática odontológica.
\end{tabular}

Assim, o modelo tradicional de ensino, centrado nos elementos estruturais da odontologia cientificista, tem sido cada vez mais criticado nos diagnósticos sobre educação odontológica no Brasil, apresentando - se em crise, dado sua ineficácia, ineficiência e desigualdade de acesso. Isto levou a busca de um novo marco conceitual que sirva a prática e a educação odontológica no Brasil, representado pela odontologia integral, que deve ser induzida a partir de uma reflexão de seus elementos estruturais, como condição básica para construção de um novo modelo de educação odontológica.

Ainda Mendes (1984) traça, especificamente, a tendência de modernização do processo educacional, no campo odontológico, defendendo a estratégia de integração docente-assistencial-investigacional que poderá conduzir na direção da "utopia desejada, o ensino inovado”.

O autor supracitado como quem sempre caminhou na vanguarda, define este modelo inovado a partir de quinze elementos de análise:

(1) "Marco conceitual: odontologia integral; 
(2) Integração das funções educacionais: docência, serviços e pesquisa são totalmente integradas;

(3) Definição do conteúdo de ensino: a partir da realidade social e das prática odontológicas;

(4) Estruturação de plano de curso: módulos integrados por níveis de atenção;

(5) Quanto às relações de conhecimento: a prática antecede a teoria, o básico é integrado ao clínico e a simulação é limitada a tarefas essenciais que ocorrem com baixa frequiência clínica;

(6) Orientação geral do currículo: dirigido para a manutenção da saúde;

(7) Espaço educacional: superação da dicotomia, ensino intra e extra mural, através de um processo educacional orgânico e diversos espaços sociais;

(8) Formação de recursos humanos: formação multiprofissional de toda a equipe odontológica;

(9) Uso de tecnologia: ensino centrado na tecnologia apropriada;

(10) Metodologia de ensino: ensino centrado em atividades de grupo;

(11) Estrutura física: áreas físicas integradas segundo nível de atenção;

(12) Planejamento educacional: realizado conjuntamente por alunos, professores, funcionários e comunidade;

(13) Natureza do pessoal docente: docente generalista integrado em módulos de ensino;

(14) Relação professor - aluno: pessoal e colaborativa;

(15) Natureza da pesquisa: dirigida à solução de problemas odontológicos da população maioritária.“ (MENDES, 1984) 
Articular um modelo inovador de ensino na direção apontada por Mendes (1984) ainda é um desafio, que ganha maior dimensão quando se olha para as práticas odontológicas. Compreendemos que a integração das práticas e da educação odontológica, por extensão, às diretrizes e princípios do SUS, não se faz a partir da Odontologia Sanitária ou Odontologia Preventiva, ou Odontologia Social ou Odontologia Simplificada e Comunitária ou Odontologia Sistêmica ou Odontologia de mercado e sim, inequivocamente, de uma odontologia no campo da saúde coletiva, conforme apontado por Narvai, (1984):

“... é o entendimento de que a saúde depende das condições de vida das pessoas, de fortalecimento do setor público, de construção de um Sistema Único de Saúde, contrário aos que fazem da cura uma mercadoria vendida com altos lucros...”

Em síntese, afirmarmos que saúde bucal coletiva apresenta como característica fundamental uma proposição que contemple, conforme Narvai (1984), escreve com propriedade, toma partido e se apaixona:

"Lutar permanentemente por liberdade políticas; opor-se frontalmente a qualquer tipo de mercantilização da prestação de serviços odontológicos e lutar para que o Estado Brasileiro, através do SUS, assuma total responsabilidade por eles; estimular, promover $e$ participar das discussões acerca da prática odontológica brasileira e da teoria que a orienta preservando, em qualquer contexto, independência crítica; lutar pela utilização de recursos odontológicos adequados à realidade sócio-econômica e epidemiológica do país; quanto aos recursos humanos, defesa, intransigente, pela justa remuneração e contínuo crescimento; opor-se radicalmente as práticas mutiladoras; lutar por uma odontologia acessível a toda população, pública, gratuita, de boa qualidade e integral; as ações preventivas não sejam apenas um apêndice das ações eminentemente curativas, mas estas estejam contempladas num enfoque de promoção da saúde; defender o ensino público e gratuito em todos os níveis e campos do saber odontológico, adequado às diferentes realidades epidemiológicas $e$ desenvolvimento do processo de ensino-aprendizagem-trabalho na realidade concreta, entendida como locais de referência do SUS; participar dos movimentos sociais populares; lutar pelo fortalecimento $e$ democratização das entidades odontológicas; lutar para que o desenvolvimento científico e tecnológico, também no campo da saúde bucal, se faça com base no intercâmbio e na cooperação entre os povos." 
Frente a esta proposição analítica e pertinente, torna-se evidente, conforme explicita Narvai (1984), que, as várias adjetivações da odontologia expressam propostas cujas práticas evidenciam a incapacidade de todas em realizar a ruptura com a odontologia de mercado.

No discurso da saúde bucal coletiva, a defesa de uma odontologia sem adjetivos que, pelo conteúdo de sua prática, afirme relações sociais democráticas, tem, com certeza, muito pouco haver com capitalismo e neoliberalismo.

Assim, ao considerarmos os dois Projetos Sanitários dispostos, hoje, no Brasil, de um lado o Projeto da Reforma Sanitária, o SUS, e do outro o Projeto neoliberal, de interesses mercantilistas, os responsáveis pela educação odontologia, no país, precisam, coerente e honestamente, posicionar-se e agir, ou pela defesa de uma prática odontológica no SUS, voltada para a saúde bucal coletiva, tornando seus serviços acessíveis à população em geral ou, então, reafirmar uma educação voltada para a odontologia empresarial, negando sua responsabilidade social.

Pinto (1990) ao examinar um conjunto de hipóteses para os menores índices de ataque pela cárie dental e o estabelecimento de estratégias preventivas populacionais, observou quatro fatores comuns a nove países; Austrália, Nova Zelândia, Estados Unidos, Dinamarca, Finlândia, Holanda, Noruega, Reino Unido e Suécia, onde houve uma pronunciada queda na prevalência e severidade da cárie dental, entre as crianças, a partir da:

Disponibilidade de fluoretos (especialmente o uso generalizado de dentifrícios fluoretados);

(1) Disponibilidade de cuidados odontológicos;

(2) Aumento da "consciência odontológica" da comunidade, junto com uma crescente utilização dos serviços odontológicos;

(3) Postura Preventiva adotada pelos profissionais. 
Outros fatores específicos comuns á vários países são: bochechos fluoretados (sete países), suplementos dietéticos fluoretados (cinco), fluoretação da água (três) e redução no consumo de açúcar (cinco). Cabe enfatizar aqui que nenhum dos nove países empregou um só sistema de adição de flúor ao organismo humano, mas naqueles onde existe a fluoretação da água de consumo, ocorreu uma grande redução dos níveis de cárie dental bem antes do que nos demais.

Pinto (2000), sintetiza as possíveis razões para o declínio da cárie nos últimos trinta anos, em países industrializados ricos, conforme Tabela 4.

Tabela 4 - Possíveis razões para o declínio da cárie nos últimos trinta anos, em países industrializados ricos

\begin{tabular}{lc}
\hline \hline RAZÕES & $\begin{array}{c}\text { BEM JUSTIFICADAS } \\
\text { TECNICAMENTE }\end{array}$ \\
\hline Dentifrícios com flúor & SIM (Principal) \\
Água fluoretada & \\
Bochecho com flúor & \\
Comprimido de flúor & SIM \\
Aplicação tópica de flúor & \\
Mudanças no consumo de açúcar & \\
Melhorias de limpeza dos dentes & \\
Mais tratamento odontológico restaurador & \\
Tratamento odontológico preventivo & \\
Prescrição de antibióticos por médicos & \\
Educação em saúde bucal & SIM \\
Mudanças no diagnóstico da cárie & SIM \\
Melhorias nas condições socio-econômicas & \\
\hline \hline
\end{tabular}

Fonte: Pinto, 2000.

Resume, diante das várias razões oferecidas por vários autores, demonstrando que entre as quatro razões consideradas de provável importância para o declínio da cárie (dentifrícios com flúor, mudanças no consumo de açúcar, mudanças no 
diagnóstico de cárie e melhoria nas condições socioeconômicas), a pasta dental com flúor é a que reúne maiores evidências científicas a seu favor (NADANOVSKY e SHEIHAM, 1995).

Assim, a partir das contribuições de Pinto (2000), observamos que o fato mais importante em relação à saúde bucal do século XX é a redução extraordinária na ocorrência da cárie dental demonstrada desde a década de 70:

"Em vários paises industrializados houve um forte declínio na média geral de dentes atacados pela cárie, e um aumento impressionante na quantidade de pessoas que nunca tiveram uma única cavidade de cárie”.(GLASS, 1982; MURRAY, 1994).

A prática de não intervir muito precocemente na lesão de cárie, é segundo o autor uma prática que deveria ser reforçada, pois parece ter sido a principal contribuição do serviço odontológico, para o declínio dos níveis do índice de dentes cariados, perdidos e obturados - CPO. Defende a relevância do papel desempenhado pelos selantes, mas com cautela, pois um programa de selantes, voltado para pacientes em níveis muito baixo de cárie, onde muitas superfícies oclusais dificilmente vão ter cárie, terá que se considerar alternativas para evitar o desperdício de custos.

Pinto (2000) conclui que o papel da odontologia na melhoria da saúde bucal está principalmente, nos serviços de alcance coletivo, como por exemplo, fluoretação das águas, dentifrícios fluoretados, educação em saúde bucal, dentre outros. Ressalta que com a redução no nível e severidade da cárie, a maioria das pessoas requer apenas intervenções básicas, de pouca complexidade. Assim, caracteriza-se a necessidade de cirurgiões dentistas generalistas e de pessoal odontológico.

Fica clara, a necessidade de rever e reter o papel do odontólogo a responsabilidade pelo diagnóstico, plano de tratamento e controle de qualidade. 
Enfim, Pinto (2000) sintetiza e sugere no Quadro 2 as implicações do declínio de cáries nas práticas odontológicos, que ao nosso ver refletem a fundamentação da saúde bucal coletiva a ser rabalhada com o estudante de odontologia, procurando fomentar e integrar-se às estratégias preventivas populacionais locais, integradas com outros programas de promoção em saúde em sua área geográfica.

Quadro 2 - Implicações do declínio de cárie nas políticas odontológicas

- Enfase na Estratégia Preventiva Populacional

- Estratégia Preventiva de Alto Risco como complementação

- Aumento da relevância do selante

- Evitar intervenção muito precoce na cárie

- Cuidado com redefinições de necessidades e tratamentos desnecessários

- Intervalos mais longos entre as consultas de revisão

- Grande parte do tratamento pode ser feita por pessoal auxiliar

- Redução do número de pessoal odontológico

- Dentistas como líderes de equipe com responsabilidade pelo diagnóstico, plano de tratamento e controle de qualidade

- Dentistas integrando-se a programa de promoção de saúde nas suas áreas geográficas

Fonte: PINTO, 2000.

Enfim, sendo impossível, trazer toda a vasta contribuição de Pinto, para o nosso referencial teórico da construção da saúde coletiva, finalizo com mais duas de suas posições; como operacionalizar o odontólogo na família e a promoção em saúde.

Pinto (1996), sugere algumas idéias para a implantação e desenvolvimento do odontólogo de Família que podem ser resumidas nas seguintes sugestões:

- "O odontólogo deve ser inserido ao esquema do PSF, aonde ele já existe, de preferência adotando a mesma clientela; 
- Pode-se adotar uma sistemática e organização e de trabalho similar à do PSF, por iniciativa local, independente do reconhecimento imediato pelo SUS;

- Embora o desejável seja atuação do odontólogo combinado com a área médica, é possível restringir a atuação da odontologia, sempre que houver demora ou resistências para o trabalho em comum;

- A clientela natural é a do próprio sistema local (ou distrito) de saúde, começando por parte dela e expandindo-se de maneira gradativa;

- O essencial é que os serviços funcionem com o enfoque nas famílias inscritas. A inscrição das famílias pode ser feita a partir de uma clientela já existente, como, por exemplo, é o caso de uma escola ou pré-escola onde as crianças já são regularmente atendidas, bastando agregar suas famílias para compor o grupo inteiro, ampliando a cobertura, gradualmente;

- Garantia de acesso aos serviços em todos os níveis de atenção é o desejado, mas, em princípio, todos os componentes de todos os grupos familiares devem ter acesso a atenção clínica básica, prevenção, educação em saúde e cuidados de urgência".

Entretanto, o autor alerta que esta prática não deve ser interpretada como algo inteiramente novo e como uma alternativa excludente às linhas de atendimento existente e sim complementar.

(EWLIS e SIMNET, 1985; ADAMS e PINTUS, 1994) ao se referir ao conceito de promoção em saúde como uma ação global, tendo como objetivos a melhoria da qualidade de vida das pessoas, considera que: “... saúde bucal é só uma pequena parte do todo. Da mesma forma, pode se considerar que a prevenção 
específica ou o tratamento de qualquer doença constituem outras parcelas deste novo e amplo movimento."

Considera, conforme (MILIO, 1983) que para a saúde e a doença o mais importante é a implementação de políticas públicas macro e em nível local, tais como decisões na área econômica e política.

Para Pinto (2000) a assimilação do cirurgião - dentista, da promoção em saúde, sob a perspectiva de uma mudança paradigmática na qual se sugere que para uma pessoa ser saudável a ausência da doença não é suficiente nem tão pouco necessária, torna-se fundamental para seu agir;

"É importante que cirurgiões dentistas e médicos se familiarizem com essa grande mudança no modelo de melhora da saúde para que sejam capazes de ver seus papéis numa melhor perspectiva e, assim, definir metas mais apropriadas para os cuidados clínicos". (PINTO, 2000)

E para concluirmos, proporcionando oportunidades para que instituições e indivíduos se "reeduquem", para uma nova forma de ensinar, refletimos sobre as bases do Programa inovador conhecido pela sigla UNI, que se mostrou capaz de contribuir, para desencadear propostas viáveis de transformação no âmbito dos três parceiros, que envolvem as universidades, serviços de saúde e comunidades.

\subsection{O IDEÁRIO UNI - UMA NOVA INICIATIVA NA EDUCAÇÃO DOS}

PROFISSIONAIS DE SAÚde E O CURSO DE GRAdUAÇÃo EM ODONTOLOGIA Similaridades Com o Projeto SAúde B UCAL Coletiva

Chaves \& Kisil, (1999), relatam que em 1968 surgiu, em Paris, um grande movimento de questionamento da universidade tradicional, sem compromisso com a 
sociedade. Tal movimento alastrou-se pelo mundo e, na América Latia, despertou a necessidade de avançar para um processo de reforma nas práticas de saúde e educação. Na década de 70, houve a criação de dois Centros Latino Americanos de Tecnologia Educacional em Saúde - CLATES, sendo um no Rio de Janeiro e outro no México, desenvolvendo papel importante em uma nova pedagogia nas escolas da área da saúde.

A Conferência Mundial sobre Atenção Primária em Saúde, ocorrida em Alma Ata, em 1978, indicou a direção para as reformas necessárias na organização da atenção básica. Ainda, na década de 70 surgem os Projetos de Integração Docente Assistencial - IDA, com a articulação de faculdades de medicina, odontologia, enfermagem e demais áreas com os serviços de saúde. Constituíram-se vários projetos e núcleos de pesquisa, apoiados pela Fundação W.K.Kellog ${ }^{2}$. Este conjunto de projetos gestou idéias de importância fundamental para que se conformasse a gênese da proposta UNI.

A necessidade de articulação entre universidade, serviço e comunidade faz parte da premissa básica do UNI. Preocupa-se com o propósito de formar profissionais comprometidos com as necessidades de saúde da população, prestação de serviços de saúde, implementação de melhorias ambientais, práticas de autocuidados e o desenvolvimento de líderes. Para tal, propõe o desenvolvimento de modelos de ensino aprendizagem inovadores e coerentes com seus objetivos.

Desde 1992, por convite da Fundação Kellog, 23 universidades e 103 cursos de graduação; 23 secretarias municipais e ou órgãos regionais de saúde e 185

\footnotetext{
${ }^{2}$ Fundação W.K.Kellog é uma entidade fomentadora de mudanças no campo social, desde sua origem, em 1930.
} 
unidades de prestação de serviços de saúde e 663 organizações comunitárias distribuídas em 11 países da América Latina, participam do UNI.

Os propósitos do UNI ao produzir mudanças sincrônicas nas universidades, serviços de saúde e comunidades participantes, bem como nas relações entre eles, foram sintetizados, segundo (Feuerwerker et al, 2000):

- Quanto às universidades: mudar o processo de formação profissional na área da saúde - mudanças de forma e conteúdo. Por um lado, incorporando os conhecimentos e tecnologias para educação de adultos (aprendizagem ativa, centrada no estudante, currículo flexível, desenvolvimento de capacidade de crítica, de investigação). Por outro, desenvolvendo currículos integrados, baseados na interdisciplinaridade, que possibilite ao estudante conhecer e enfrentar os problemas da realidade desde o inicio do processo de formação, tendo a possibilidade de estabelecer relações mais humanas e responsáveis com a população e de conhecer por dentro o funcionamento e as necessidades dos serviços de saúde;

- Mudar os serviços de saúde: contribuindo para que se tornem mais efetivos, integrados, conhecedores da realidade local, acessíveis à população, comprometidos com a resolução de seus problemas, passando ser participantes ativos do processo de formação profissional;

- Ampliar o acesso da comunidade: aos conhecimentos em saúde, às tecnologias fundamentais para seu desenvolvimento mais autônomo, fortalecendo suas organizações próprias e sua capacidade de intervenção local.

O UNI, a partir de sua Rede UNIDA (2000), tem acumulado significativa experiência relacionada à transformação dos modelos acadêmicos em estreita 
articulação com a construção de novos modelos de atenção à saúde e com o desenvolvimento comunitário.

Ao realizarmos a revisão bibliográfica sobre o tema desta dissertação, principalmente, nos aspectos que se referem às questões pedagógicas e educacionais, encontramos similaridade entre os objetivos do Projeto Saúde Bucal Coletiva Saúde e Cidadania e, especialmente, aqueles estabelecidos pelo Projeto UNI, oferecendo sustentabilidade ao nosso referencial teórico.

O propósito do UNI é de produzir mudanças sincrônicas nas universidades, nos serviços de saúde, nas comunidades e nas suas relações - desenvolvendo currículos integrados, baseados na interdisciplinaridade, que possibilitem ao estudante conhecer e enfrentar os problemas da realidade desde o início do curso.

Constatamos, então, que a aprendizagem baseada em problemas, que é parte do enfoque de responsabilidade social defendida pelo UNI é inerente aos objetivos do Projeto Saúde Bucal Coletiva. Assim, as várias leituras que realizamos sobre o Projeto UNI, especialmente (Almeida et al, 1999), possibilitour nos sintetizar, de forma mais clara e objetiva, as intenções do Projeto Saúde Bucal Coletiva com os estudantes de odontologia que se graduarão, neste Centro Universitário.

Constatamos, também, que, parte dos objetivos do Projeto Saúde e Cidadania, almejados para a formação dos estudantes de odontologia, são similares às habilidades, competências e atitudes almejadas pelo Projeto UNI, para categoria de médicos e enfermeiros, quais sejam:

- "Identificar os problemas de saúde prioritários e procurar soluções para garantir a equidade, a eficiência, a relevância e a qualidade; 
- Tornar-se ativo, com habilidades de avaliação crítica, destrezas de aprendizagem que o conduza ao longo da vida, capaz de reconhecer e melhorar suas fontes de informação;

- Promover respeito, humanismo e eficiência profissional;

- Fortalecer o trabalho interdisciplinar e enfatizar de modo especial o desenvolvimento de um trabalho com a comunidade, na perspectiva da família, e de acordo às suas necessidades;

- Promover a habilidade para integrar conceitos biológicos, de comportamento e sócio-econômicos, indivisíveis na realidade dos processos de saúde;

- Promover a compreensão de conceitos, tecnologia e mecanismos que o instrumentalize para atuar em abordagens coletivas em saúde bucal;

- Estabelecer fortes laços entre o atendimento individual e os aspectos básicos da saúde populacional;

- Estabelecer relações mais horizontais e de dupla via com os serviços de saúde e com a comunidade do seu entorno;

- Desenvolver compromisso social, estabelecendo a comunidade como sujeito dentro do trabalho de saúde;

- Promover conhecimento experimentados/aprendidos após ter vivido experiências, permitindo formar profissionais com capacidade de solução de problemas;

- Adotar uma visão holística da problemática da saúde e

- Aprender que não é suficiente uma boa gerência do nível primário, mas que é preciso articular os diversos níveis de complexidade”. (Almeida et al, 1999). 
Diante do convite da Secretaria de Ensino Superior (SESU) do Ministério de Educação e Desportos (MEC), feito através do Edital 04/97, a Rede UNIDA (2002) apresentou sua contribuição para as novas Diretrizes Curriculares dos cursos da área de saúde.

Esta contribuição, portanto, é produto do trabalho de dezenas de pessoas que acreditam na disposição das Comissões de Especialistas da SESU e da Câmara de Ensino Superior do Conselho Nacional de Educação (CNE) em repensar e renovar a educação dos profisssionais de saúde no nosso país.

Assim, sintetizamos a contribuição da Rede UNIDA (2002) para as novas diretrizes curriculares dos cursos de graduação da área de odontologia:

\section{Quanto ao perfil do dentista a ser graduado}

\section{a) Competências e Habilidades}

A educação de adultos pressupõe a utilização de metodologias ativas de ensino-aprendizagem, que proponham concretamente desafios a serem superados pelos estudantes, tendo o professor como facilitador e orientador do processo.

Considerando que os anos da graduação restringem-se a um máximo de cinco anos e que a vida profissional pode estender-se por três décadas ou mais, e considerando-se também que os conhecimentos, habilidades e atitudes exigidas do profissional modificam-se rapidamente, temos que um dos objetivos de aprendizagem fundamentais do curso de graduação é o de aprender a aprender.

Aprender a aprender envolve o desenvolvimento de habilidades de busca, seleção e avaliação crítica de dados e informações disponibilizadas em livros, 
periódicos, bases de dados locais e remotas, além da utilização das fontes pessoais de informação, incluindo a advinda de sua própria experiência profissional.

Além disso, algumas premissas devem ser destacadas para a graduação de um bom profissional:

- Planejamento, execução e avaliação de serviços de saúde comunitária;

- Trabalho em equipe de saúde;

- Aptidão a promover a saúde, a biossegurança e a bioética.

\section{Conteúdos Curriculares}

O Curso de Odontologia deve ter um projeto pedagógico centrado no aluno como sujeito da aprendizagem e apoiado no professor como facilitador do processo de ensino-aprendizagem, privilegiando o aprendizado baseado em problemas e orientado para a comunidade.

A pedagogia da interação supera com vantagens a pedagogia da transmissão passiva de conhecimentos, utilizada nos métodos tradicionais de ensino, possibilitando o aperfeiçoamento contínuo de atitudes, conhecimentos e habilidades dos estudantes. Facilita o desenvolvimento do seu próprio método de estudo, possibilitando que aprenda a selecionar criticamente os recursos educacionais mais adequados, a trabalhar em equipe e a aprender a aprender.

O segundo conceito chave do modelo pedagógico deve ser o de aprender fazendo, que propõe a inversão da sequiência clássica teoria/prática caracterizando que o processo do conhecimento ocorre na ordem inversa, ou seja, da prática para a teoria. 
$\mathrm{Na}$ realidade, pretende-se conjugar o enfoque pedagógico que melhor desenvolve os aspectos cognitivos da educação (aprender a aprender), com o enfoque que permite o melhor desenvolvimento das habilidades psicomotoras e de atitudes (aprender fazendo).

Enfim, o modelo pedagógico do curso deverá ser fundamentado nos princípios da pedagogia interativa, de natureza democrática e pluralista, com um eixo metodológico firmemente estabelecido e que priorize metodologias ativas de ensinoaprendizagem.

A Prática Baseada em Evidências deve nortear o cotidiano clínico de diagnose e terapêutico, buscando sempre indicar quais são procedimentos mais seguros e eficazes para os pacientes. Desta forma, faz-se necessário valorizar em todos os momentos do currículo o questionamento: qual é a melhor evidência em defesa desta argumentação, hipótese ou conduta?

\section{Estrutura Modular}

É preciso buscar integrar as dimensões biológica e social (psicológica, populacional, etc.) ao longo de todo o curso de graduação. Para tanto ele deverá ser organizado através de módulos. Eles poderiam orientar-se em sua construção por sistemas orgânicos, ciclos de vida ou apresentações clínicas, integrando um conjunto nuclear de conhecimentos, habilidades e atitudes a serem desenvolvidos como objetivos educacionais.

Em cada módulo estão embutidos os conteúdos das disciplinas necessários para contemplar e completar seus enunciados. As disciplinas, então, passam a cumprir seu verdadeiro papel que é o de áreas de conhecimento. 
Assim, propõe integrar as seguintes matérias: Ciências Morfológicas; Fisiológicas; Patológicas e Sociais; Propedêutica Clínica; Clínica Odontológica; Odontologia Pediátrica; Odontologia Social e Clínica Integrada.

A operacionalização dos conteúdos modulares pode se dar através de problemas relacionados ao processo saúde-doença, com base nas respectivas árvores temáticas.

\section{Estágios e Atividades Complementares}

A inserção precoce dos estudantes na realidade é fator decisivo para que o olhar de cada estudante detenha-se no exame da realidade que o circunda. Assim devemos criar múltiplas oportunidades de interação na, com e para a comunidade, centrando a atenção de cada estudante da graduação para uma área de abrangência dos serviços ao longo dos anos de graduação, permitindo um enraizamento que legitime a atuação do estudante em um local de referência.

Desta forma, propomos o desenvolvimento de um módulo interdisciplinar que percorra os anos de graduação com o propósito de interagir com a comunidade: identificando problemas e objetivos comuns, buscando soluções, desenvolvendo uma parceria.

\section{Avaliação do Estudante e Avaliação do Programa}

A avaliação não deve restringir-se à avaliação do estudante, ou do produto, e sim fazer parte da avaliação do programa como um todo, ou melhor dizendo, do processo de formação profissional.

Deve-se considerar a avaliação formativa como eixo central da avaliação dos estudantes, permitindo que cada estudante tenha a possibilidade de resgatar 
conhecimentos, habilidades ou atitudes não adquiridas ao final de cada módulo ou unidade educacional, possibilitando uma recuperação em casos de insucesso, não marginalizando, mas integrando, cooptando.

A preocupação fundamental deve ser com a formação de cada estudante, e não somente com a avaliação somativa, de seus pontos e médias, por vezes meramente punitiva ou comparativa.

\section{Duração do Curso}

O curso de odontologia terá a duração mínima de 10 (dez) e máximo de 18 (dezoito) semestres letivos.

Compreendemos que na área da saúde a implantação do SUS e a construção de um novo modelo de atenção enfrentam grandes dificuldades por não estarem sendo acompanhadas de mudanças no perfil e nas competências dos profissionais que estão sendo formados.

A REDE UNIDA entende que a transformação da universidade não vai ser produto exclusivo da iniciativa de seus professores e estudantes. A abertura para a discussão e a interação com outros segmentos da sociedade vai ser fundamental para ajudar a iluminar o caminho e a construção de alternativas para a situação atual. Entretanto, com certeza, proporciona aos interessados nesta mudança curricular e de postura dentro das universidades, uma nova perspectiva sistematizada e fundamentada, para o enfrentamento das causas dos problemas odontológicos, através da formação do profissional de odontologia concernente com a realidade.

Nesta virada de século, a forma como se organizam o ensino, a pesquisa e a questão dos serviços de saúde, na universidade brasileira, conforme menciona Pinotti (1984), esta longe de atender de modo adequado às necessidades sociais 
predominantes, terminando por reforçar os padrões da prática médica vigente, modelo curativista e o status quo do complexo médico-industrial.

Nesta perspectiva e considerando o Brasil um país de acentuadas disparidades regionais e sociais, urge que as universidades voltadas para o ensino na área da saúde, concentrem maiores esforços na pesquisa de alcance social, não podendo escapar à sua condição de instrumento de melhoria das condições de saúde da população.

Para a concretização desta missão, torna-se imprescindível colocar o ensino brasileiro em consonância com a realidade social do país, inserindo-se nessa realidade para, com base em fatos, estabelecer não só a revisão dos métodos de ensino-aprendizagem como também a proposição de um conjunto de medidas indispensáveis à reestruturação administrativa e pedagógica das instituições de nível superior.

Consideramos pertinente a afirmação de Rodrigues (1987) quando diz que “... antes de educar para um trabalho, é preciso educar para o trabalho...”, concedendo ao aluno uma sólida, lúcida e ampla formação fundamentada nas atuais necessidades sociais, com visão humanística e inteirando-se dos princípios científicos, sociais e tecnológicos que regem o mundo da produção, do consumo e das leis de mercado de trabalho.

Acreditamos que o aprendizado em relação às questões de saúde não se faz apenas nos livros e na sala de aula, mas no confronto com problemas reais. A crescente demanda de uma nova concepção de saúde pública no mundo, e em especial no Brasil, tem exigido respostas alternativas e criativas, na perspectiva da ampliação do conceito de saúde, significando bem - estar, qualidade de vida, 
transcendendo a idéia de "vida sem doença" e que a promoção da saúde não concerne exclusivamente ao setor sanitário. A Carta de Otawa, já amplia o conceito vigente de saúde, traçando alguns pré-requisitos e condições como: " $a$ paz, $a$ educação, a habitação, a alimentação, a renda, um ecossistema estável, a justiça social e a equidade"(XAVIER, 2000). O documento sustenta que a promoção da saúde está centrada em assegurar a igualdade de oportunidades e proporcionar os meios que permitam à população fazer suas opções, sendo capazes de assumir o controle de tudo o que determina o seu estado de saúde.

Desta forma, o sentido, do desafio educacional contemporâneo, na área da saúde coletiva como campo aberto para novos paradigmas, aponta para o ensino integrado com a comunidade, a pesquisa e os serviços de saúde, nas instituições de nível superior.

Contudo, para que ocorra a real integração das instituições de ensino à rede assistencial de saúde e com a comunidade, passando o sistema educacional a interagir com o de prestação de serviços, na prática, alguns questionamentos vêm à tona: Como deve ser ministrado? Qual é o seu significado num processo de educação integral? Que importância deve ter para o educando, como ser humano, e como elemento integrante desta força de trabalho em saúde? O que e como fazer para que a universidade assuma sua plena responsabilidade na área da saúde? O que pretendem os instrumentos legais de reformulações de ensino ao conceder destaque aos projetos de pesquisa e extensão? É possível desenvolver projetos de qualidade na área de saúde coletiva, em universidades privadas, neste contexto de exortação do neoliberalismo? O que fazer para que a universidade atue como agente de mudança, 
papel que lhe cabe como nenhum outro, considerando sua natureza crítica e investigadora?

Enfim, conforme questionam Paim \& Almeida Filho (2000) ao apresentarem uma breve sistematização do marco conceitual da saúde coletiva;

"Qual é o núcleo básico de conhecimentos e habilidades que deverão compor o novo perfil profissional num contexto que incorpora novos atores para o seu âmbito de ação, exigindo capacidade de negociação, agir comunicativo e administração de conhecimentos?"

Essas e outras indagações fazem parte do escopo deste projeto, propondo um componente que vem se somar ao conjunto de estratégias de integração ensinoserviço - comunidade, desenvolvidas por várias instituições no país, analisando a contribuição do Projeto de Pesquisa e Extensão em Saúde Bucal Coletiva desenvolvido, a partir de 1999, pelo Curso de Odontologia do Instituto de Ciências da Saúde, do Centro Universitário do Triângulo - UNIT, em Uberlândia, Minas Gerais, uma instituição de ensino superior privado.

É preciso esclarecer que o referido Projeto não se trata de uma reformulação de todo o curso de Odontologia da UNIT, como proposto pelo ideário UNI, mas somente de uma parte do curso de graduação, portanto esta situação já aponta algumas limitações para se conseguir mudanças amplas. 


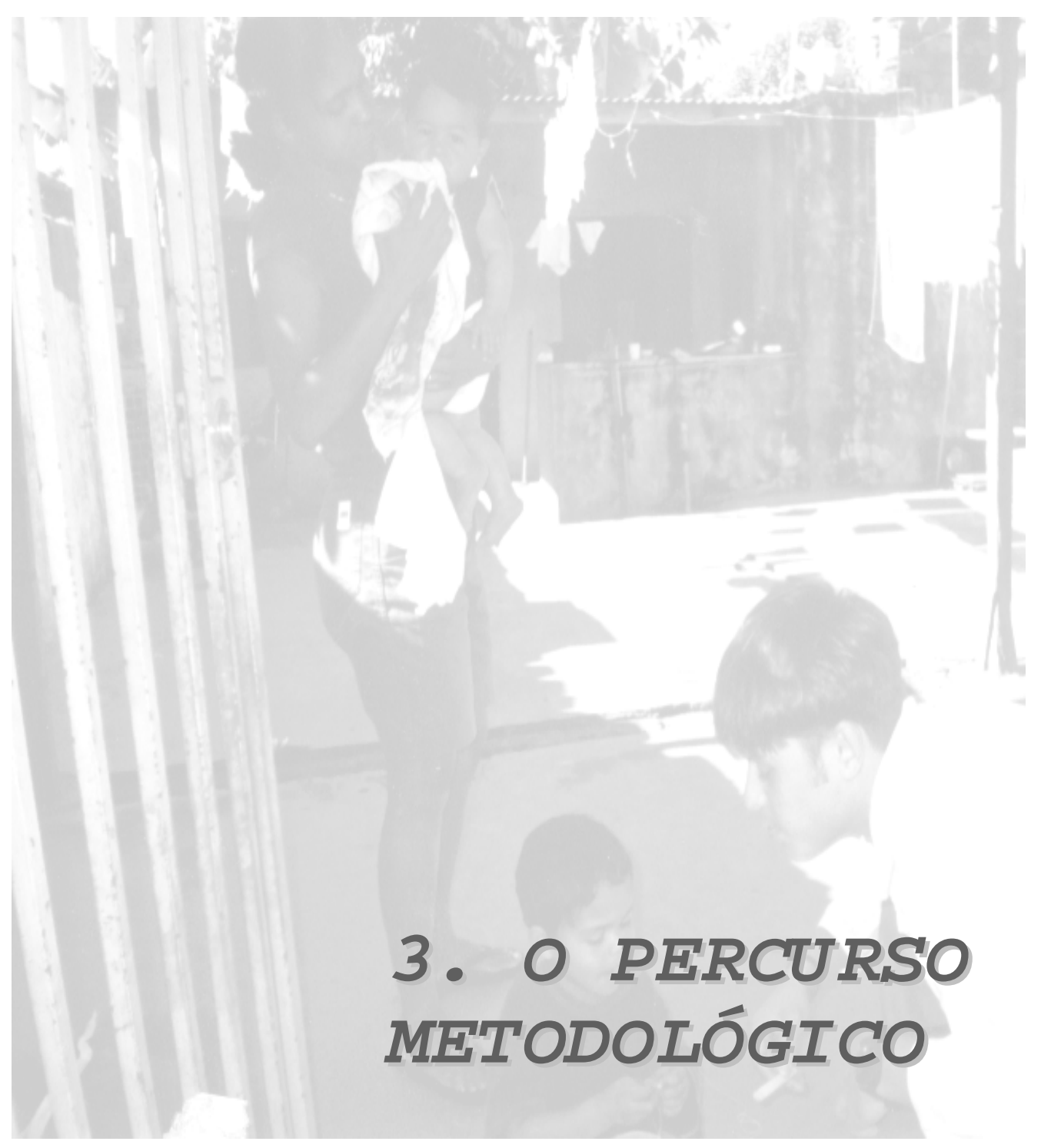




\subsection{O ESTUDO DE CASO}

O trabalho trata de um estudo descritivo do Projeto Saúde Bucal Coletiva e é um estudo de caso. Analisamos a sua abrangência a partir da visão de seus sujeitos: o estudante do curso de odontologia.

Segundo Ludke \& André (1986), o caso pode ser similar a outros, mas é ao mesmo tempo distinto, pois tem um interesse próprio e singular. O caso é sempre bem delimitado, devendo ter seus contornos claramente definidos no desenrolar do estudo.

Os autores Goode e Hatt (1960), consideram que o caso se destaca por se constituir numa unidade dentro de um sistema mais amplo. O interesse, portanto, incide naquilo que ele tem de único, de particular, mesmo que posteriormente venham a ficar evidentes certas semelhanças com outros casos ou situações. Assim, optamos pelo estudo de caso, pois estudamos algo singular, que tem um valor em si mesmo.

Alguns autores acreditam que todo estudo de caso é qualitativo. Ludke \& André (1986) definem o estudo qualitativo como: “... aquele que se desenvolve numa situação natural, é rico em dados descritivos, tem um plano aberto e flexível e focaliza a realidade de forma complexa e contextualizada”.

Os autores supracitados caracterizam o estudo de caso, destacando que os mesmos: visam à descoberta; enfatizam a "interpretação em contexto"; buscam retratar a realidade de forma completa e profunda; usam uma variedade de fontes de informação; revelam experiência vicária e permitem generalizações naturalísticas; 
procuram representar os diferentes e às vezes conflitantes pontos de vista presentes numa situação social e utilizam uma linguagem e uma forma mais acessível do que os outros relatórios de pesquisa.

É necessário ressaltar que neste projeto de pesquisa, desenvolvemos, concomitantemente, o papel de pesquisadora e de pesquisada, considerando que somos uma das autoras do Projeto Saúde Bucal Coletiva, dentre um grupo de quatro docentes do curso de odontologia.

Durante o percurso metodológico pretendemos ficar atentos a nossa tendência a avaliar positivamente o Projeto estudado, considerando que estaremos ao mesmo tempo desempenhando dois papéis, ou seja, do investigador e do investigado, do pesquisador e do pesquisado, procurando demarcar as contradições presentes e contextualizando-as durante este caminhar sistematizado.

Vale ressaltar que esta pesquisa permitirá a curto e médio prazo, retorno em forma de benefícios para os alunos, considerando a indicação de reajustes necessários ao Projeto, que foram identificados, viabilizando propostas de adequação ao mesmo, com a objetividade e clareza de quem recebeu suas atividades de ensino.

\subsection{A POPULAÇÃo EM ESTUDO}

Definimos como a população em estudo os alunos do curso de odontologia que concluíram, minimamente, dois anos, do ciclo básico, de participação no Projeto, ou seja, já cursaram as etapas referentes aos $2^{\circ}, 3^{\circ}, 4^{\circ}$ e $5^{\circ}$ períodos e que já tenham iniciado a sua última etapa, o ciclo clínico, referente ao $7^{\circ}$ ou $8^{\circ}$ período, do referido curso. 
Estudantes que preencheram, em setembro de 2002, as condições estabelecidas para participar da pesquisa, estavam cursando o quarto ano do curso de odontologia ( $7^{\circ}$ e $8^{\circ}$ períodos) e corresponderam a 59 (cinqüenta e nove) alunos, de um universo de 247 alunos matriculados, nos períodos em que já se aplicou ou está aplicando o projeto, de agosto de 1999 a setembro de 2002, conforme demonstrado na Tabela 5 .

Tabela 5 - Relação de alunos matriculados e participantes do Projeto, no período de agosto (1999) a setembro (2002), do curso de odontologia. Uberlândia, 2002

\begin{tabular}{|c|c|c|c|c|}
\hline ANO & PERÍODO & $\begin{array}{c}\text { ALUNOS } \\
\text { MATRICULADOS }\end{array}$ & $\begin{array}{c}\text { ALUNOS } \\
\text { PARTICIPANTES DO } \\
\text { PROJETO * } \\
\end{array}$ & $\%$ \\
\hline \multirow{2}{*}{1999} & $1^{\mathrm{o}}$ & 59 & - & - \\
\hline & $2^{o}$ & 56 & 56 & 100 \\
\hline \multirow{2}{*}{2000} & $3^{\circ}$ & 55 & 55 & 100 \\
\hline & $4^{\circ}$ & 44 & 44 & 100 \\
\hline \multirow{2}{*}{2001} & $5^{\circ}$ & 33 & 33 & 100 \\
\hline & $6^{\circ}$ & 34 & - & - \\
\hline \multirow{3}{*}{2002} & $7^{\circ}$ & 30 & 28 & 93 \\
\hline & $8^{\circ}$ & 31 & 31 & 100 \\
\hline & Total & 342 & 247 & 67 \\
\hline
\end{tabular}

\subsection{INSTRUMENTOS DA PESQUISA}

Adotamos como instrumentos para a coleta de dados dois questionários. O primeiro questionário corresponde a um formulário institucional, estruturado e aplicado pelo Centro Universitário do Triângulo, em forma de questionário 
preenchido pelo aluno, no ato da inscrição para o vestibular (Anexo E), posteriormente após, analisados, são arquivados, junto a pasta do aluno, aprovado por esta instituição formadora. Através do primeiro questionário, identificamos o perfil social dos alunos do $7^{\circ}$ e $8^{\circ}$ períodos, que ingressaram na UNIT, em fevereiro de 2000 e agosto de 1999, respectivamente. Este questionário refere-se ao aspecto sócio, cultural e econômico do estudante de odontologia.

O segundo questionário, semi-aberto (Anexo $F$ ), foi elaborado, especialmente, para alcançar os objetivos propostos pelo presente trabalho e aplicados através de três auxiliares de pesquisa. A aplicação deste segundo questionário, objetivou conhecer, através da visão dos alunos, a importância que a saúde bucal coletiva ocupou em sua formação, durante este período de contato com as práticas, assim como o conteúdo do projeto e em que escala de importância. Obtivemos informações se esta área, de abordagens coletivas em saúde bucal, faria parte de sua escolha de atuação profissional, conhecemos, também, as concepções, ações e as análises construídas em relação às atividades propostas e os aspectos considerados mais importantes, colhendo inclusive opiniões diferenciadas sobre o Projeto.

Identificamos as fases consideradas mais sensibilizantes e transformadoras, assim como os aspectos de pouco relevância, na opinião do aluno. Identificamos os fatores que merecem reforços positivos, para sua continuidade e os que necessitam de revisão e reajustes, enquanto processo de ensino-aprendizagem.

Interessou - nos conhecermos, também, os motivos de escolha do curso de odontologia, possibilitando-nos maiores informações sobre o perfil deste aluno, 
tendo sido útil quando da análise das suas respostas frente a este Projeto de cunho social.

Realizamos um pré-teste, junto a cinco estudantes de odontologia, sendo dois do $7^{\circ}$ período e três do $8^{\circ}$ período, possibilitando-nos sintetizar o questionário em 14 questões que consideramos mais importantes e que respondiam aos objetivos traçados pela pesquisa.

Decidimos, antecipadamente, e planejamos convidar para aplicação dos questionários, três auxiliares de pesquisa, sendo que duas são psicólogas e contamos, também, com a colaboração de uma cirurgiã-dentista. Caracterizam-se pelos conhecimentos e habilidades para a coleta de dados, e pelo fato de não possuírem relações afetivas e de vínculo professor/aluno, como se caracteriza a nossa situação. Além disto, se nos realizássemos estas entrevistas com os alunos, provavelmente poderia inibi-los, no momento da entrevista, ao colocarem seus pareceres sobre o Projeto. Assim como, criar um viés em nossa pesquisa, considerando a possibilidade do estudante poder influenciar-se por nossa presença e não dissociar sua opinião do Projeto, da nossa pessoa ou do papel de professora pesquisadora.

Os questionários sendo aplicados por auxiliares de pesquisa não envolvidos diretamente com este estudo de caso, com certeza enriqueceram o processo de coleta e análise dos dados, contribuindo com outros olhares e favoreceram uma análise que busca o distanciamento do objeto pesquisado e da possibilidade de análises não afetivamente envolvidas com o referido estudo de caso.

Antes de iniciar o processo de coleta de dados, através da aplicação dos questionários, com os alunos do curso de odontologia, proporcionamos orientações, junto a estes auxiliares de pesquisa convidados, sobre aspectos relevantes do estudo 
de caso, o perfil do aluno pesquisado, os objetivos da pesquisa e como deveriam ser coletadas e registradas as informações, preservando anonimato e não induzindo a resposta. Discutimos as perguntas do questionário elaborado, procurando calibrar, esclarecer e proporcionar homogeneização sobre este projeto de pesquisa, tendo como finalidade um padrão de condutas na realização das mesmas.

\subsection{ANALISE DOS DADOS}

Todas as variáveis utilizadas no questionário são qualitativas, exceto idade que foi possível categorizar a priori, após o levantamento de dados e calculamos a média de idade dos estudantes que responderam ao questionário. O nosso trabalho foi descritivo, apresentando as variáveis por meio de frequiências simples ou relativas e trabalhando com a classificação das respostas em grupos mais homogêneos.

A abordagem descritiva qualitativa foi predominante, tendo em vista o referencial teórico, a natureza do objeto pesquisado e por se tratar de nossa escolha metodológica, obtendo o que há de positivo e contributivo, para o Projeto analisado.

Os questionários aplicados representaram instrumentos básicos para a coleta de dados, dentro da perspectiva da pesquisa social. Eles desempenharam importante papel na coleta de informações sobre o perfil social do aluno e o conhecimento adquirido pelo mesmo e sob sua visão a análise dos pontos positivos e restritivos do Projeto. 


\subsection{AS QUESTÕES ÉTICAS DA PESQUISA}

É exigido que toda pesquisa se processe após consentimento livre e esclarecido que por si e/ou por seus representantes legais manifestem a sua anuência à participação na pesquisa, considerando o respeito devido à dignidade humana.

Como nossa pesquisa se tratava de estar analisando, pela visão do aluno, as contribuições do Projeto, a sua participação teve que ser consentida e assegurada o seu anonimato, garantindo a ele responder se queria participar. No Anexo G, encontra-se o modelo de termo de consentimento utilizado para solicitar a participação do estudante de odontologia.

Antes de iniciarmos a coleta de dados em campo, seguindo as normatizações da Comissão Nacional de Ética em Pesquisas - CONEP, presentes na resolução do CNS 196/96 e capítulo IV da Resolução 251/97, o projeto de pesquisa passou por aprovação do Comitê de Ética em Pesquisa da Escola de Enfermagem de Ribeirão Preto - Universidade de São Paulo, tendo sido aprovado sem ressalvas.

Encontra-se, também, em (Anexo H) a autorização da UNIT, para a utilização do questionário sobre o perfil sócio, econômico e cultural do estudante de odontologia e para a aplicação do segundo questionário, sobre a contribuição do Projeto. 
4. RESULTADOS

E DISCUSSÃO 
Este capítulo está dividido em duas grandes partes, na primeira apresenta a caracterização pessoal e social do estudante de odontologia do Centro Universitário do Triângulo - UNIT, por ocasião do ingresso na universidade e a segunda parte descreve e discute sobre as contribuições do Projeto Saúde Bucal Coletiva, para a sua formação, referente às respostas do estudante de odontologia ao questionário aplicado.

\subsection{PERFIL DO ESTUDANTE DO CURSO DE ODONTOLOGIA DA UNIT, POR OCASIÃO DO INGRESSO NA UNIVERSIDADE.}

\subsubsection{Características pessoais do estudante: sexo, idade, estado civil, número de filhos e religião}

Analisando o levantamento efetuado pelo Centro Universitário do Triângulo UNIT, sobre os aspectos sócios culturais dos 59 estudantes ingressantes ao curso de odontologia $^{3}$, em janeiro e julho de 1999, e que hoje estão cursando o quarto ano, com vistas ao conhecimento do perfil do candidato, obtivemos os seguintes resultados: 37 dos estudantes ingressantes, supracitado, eram do sexo feminino (74\%) e 13 do sexo masculino (26\%), 26 estudantes ingressaram no curso de odontologia com menos de 20 anos (52\%), sendo que a outra parte, entre 20 a 30 anos $46 \%$, e apenas um (2\%) tinha mais de 30 anos.

Quanto ao estado civil $86 \%$ era solteiro, $12 \%$ casados e $2 \%$ alegaram outro estado civil. Quanto ao número de filhos $86 \%$ não os tinha, $10 \%$ tinham entre um e 
dois filhos e $4 \%$ tinham entre três e cinco filhos. Quanto à religião, 74\% se diziam católicos, $16 \%$ cristãos não católicos, $6 \%$ sem religião, com fé em Deus e $4 \%$ outra religião. Nenhum estudante apresentou - se como ateu ou judaico.

Verificamos que a grande maioria dos estudantes ingressantes não tinha filhos e estavam solteiros. A religiosidade encontrada reproduz, em certa medida a opção da população brasileira que apresenta $74.9 \%$ de católicos; $13.3 \%$ de evangélicos; $3.5 \%$ de cardecistas; $1.3 \%$ de Afro-brasileiros; $2.0 \%$ de outras religiões e $4.9 \%$ de nenhuma religião.

Os estudantes de odontologia ingressaram na universidade em idade jovem, reproduzindo o perfil do aluno brasileiro, conforme divulgado por pesquisa recente publicada na Folha de São Paulo. (FOVEST, 2002).

Observamos que também ocorre feminização no Curso de Odontologia, como em outras áreas da saúde, sendo, $74 \%$ dos ingressantes ao curso, do sexo feminino e $26 \%$ do sexo masculino.

O aumento da participação feminina (feminização) no mercado de trabalho em saúde é analisado por Machado et al. (1992), observando que até 1970, a participação feminina no conjunto da força de trabalho em saúde era relativamente reduzida, embora existissem algumas categorias profissionais que, por tradição, eram ocupadas por mulheres, tais como parteiras, auxiliares, técnicos e atendentes de enfermagem e enfermeiros.

Entre 1970 e 1980, o contingente feminino entre os médicos aumentou de $11,6 \%$ para $20,6 \%$ e, entre os dentistas, evoluiu de $11,5 \%$ para $28,2 \%$. Consideram como consequiência deste movimento, específico da década, a força de trabalho

${ }^{3}$ Destes 59 estudantes ingressantes ao curso de odontologia, em 1999, e que estão cursando em 2002 o $4^{\circ}$ ano do Curso de Odontologia, por diferentes razões, como, por exemplo, ter vindo transferido de outra universidade, nove questionários não foram encontrados, utilizando-se para análise 50 questionários respondidos. 
feminino nestas profissões ser eminentemente jovem, conforme demonstrado na Tabela 6.

Tabela 6 - Relação da mão-de-obra feminina na força de trabalho em saúde, segundo algumas categorias profissionais. Brasil, 1970-1980

\begin{tabular}{|c|c|c|}
\hline \multirow{2}{*}{ CATEgorias ProfissionaIS } & \multicolumn{2}{|c|}{ NÚMEROS RELATIVOS } \\
\hline & 1970 & 1980 \\
\hline Médicos & 11,57 & 20,62 \\
\hline Odontólogos & 11,31 & 2820 \\
\hline Farmacêuticos & 40,06 & 37,71 \\
\hline Enfermeiros & 95,98 & 94,02 \\
\hline Pessoal de Enfermagem & 81,91 & 82,98 \\
\hline
\end{tabular}

Ainda, Machado et al. (1992) analisam que a "feminização" do emprego do setor saúde do Brasil nos anos setenta não deve ser explicado do ponto de vista global, mas, ao contrário deve responder às distintas peculiaridades atinentes a cada categoria ou grupo de categorias como observado na Tabela 6. Explicam este fato, no caso dos empregos de nível superior, atribuindo a reforma universitária a possibilidade de maior ingresso de mulheres nas universidades, particularmente em cursos que detinham tradição masculina, como medicina e odontologia. Atribuem, também, às mudanças sócio-culturais favorecendo maiores níveis de aceitação social da mulher no mercado de trabalho. Destacam, dentre os diversos fatores que contribuíram para este fenômeno, o papel que o emprego feminino passou a ter na composição do orçamento doméstico, dado que o período caracterizourse pela substancial perda do poder aquisitivo dos trabalhadores advindo da política de arrocho salarial. 


\subsubsection{Instrução dos Pais}

Quanto ao nível de instrução do pai predomina, o nível superior completo (40\%); superior incompleto (4\%); seguido pelo segundo grau completo (20\%); primeiro e segundo graus incompletos que somam um percentual de $(24 \%)$; primeiro grau completo (10\%) e nenhum estudo $2 \%$.

Quanto ao nível de instrução da mãe predomina o segundo grau completo (36\%); seguido pelo superior completo (28\%), em seguida superior incompleto (14\%); segundo grau incompleto (12\%) e primeiro grau completo e incompleto somam (16\%). Não registrou - se mãe sem nenhum estudo.

Observamos que, quanto à instrução dos pais dos estudantes de odontologia, predomina a escolaridade superior e segundo grau completo, reproduzindo, também, uma pesquisa recente que demonstra a relação direta entre pais instruídos e quantidade de anos de escolaridade dos filhos.

“... se o pai não estudou, o filho só fica três anos na escola. Mas, se o pai tiver cursado o ciclo elementar, ainda que sem completá-lo, o tempo de permanência do filho na escola dobra. No limite, filhos de quem fez doutorado estudam durante quatorze anos." (Mendonça, 2002, p. 91).

A consequiência econômica da educação tem muito impacto. Um trabalho do Instituto de Pesquisa de Economia Aplicada - IPEA, mostra que a garantia da escolaridade de cinco anos para toda a população brasileira faria a miséria cair $6 \%$. A mesma garantia por dez anos reduziria a pobreza em 13\%. (Mendonça, 2002, p. 91). 


\subsubsection{Município de residência do estudante e modalidade de imóvel que a família reside}

A maioria dos estudantes reside no mesmo município do Centro Universitário, em Uberlândia (66\%); 20\% residem em outros municípios; 8\% residem no município de Araxá e 6\% residem no município de Araguari, municípios estes bem próximos do município de Uberlândia.

Obtivemos que $88 \%$ residem em imóvel próprio, $4 \%$ em imóvel alugado e $8 \%$ em outra modalidade não identificada.

Observamos, também, que a modalidade de imóvel que a família reside, predominando o imóvel próprio, demonstra um poder aquisitivo melhor do estudante de odontologia, pertencente a uma classe média alta.

\subsubsection{Renda total da família, situação do estudante quanto a executar trabalho remunerado e o tipo de trabalho}

Somando-se as famílias que recebem de 10 a 20 e de 20 a 50 salários mínimos, obtivemos $73.4 \%$ das famílias recebendo entre 10 a 50 salários mínimos; seguido por $12.2 \%$ das famílias recebendo mais de 50 salários mínimos; $8.2 \%$ de três a cinco salários mínimos; $4,1 \%$ de 5 a 10 salários mínimos e $2 \%$ recebendo até três salários mínimos.

Verificamos que $88 \%$ dos estudantes não exercem atividades remuneradas, ou seja, não trabalham; $6 \%$ exercem eventualmente; somam-se $4 \%$ os que exercem atividades remuneradas em tempo parcial e integral e $2 \%$ não registrou resposta.

Os $12 \%$ dos alunos que registraram que trabalham o fazem, predominantemente no comércio (40\%); sendo que o restante divide-se 
homogeneamente entre empresa pública, magistério e outras atividades, somando $60 \%$.

Demonstrando, mais uma vez, que o estudante de odontologia vem de uma classe média alta e não precisa contribuir com a renda familiar.

\subsubsection{Modalidade de Escola em que concluiu o segundo grau, tipo de ensino médio e se freqüentou curso pré-vestibular (cursinho) e}

\section{freqüência que prestou o vestibular}

Observamos que $77.6 \%$ dos alunos cursaram o segundo grau em escola particular, sendo que apenas $4.1 \%$ com bolsa e $22.4 \%$ em escola estadual. $73.5 \%$ fizeram formação geral no segundo grau; $16.3 \%$ curso técnico; $8 \%$ curso profissionalizante e 2\% curso normal. Quanto ao curso preparatório para ingresso, $82 \%$ freqüentou curso pré-vestibular (cursinho), sendo que $40 \%$ uma vez, $28 \%$ três vezes ou mais e $14 \%$ duas vezes. $84 \%$ dos alunos já prestaram vestibular pelo menos uma vez, sendo que $44 \%$ três vezes ou mais; $22 \%$ duas vezes; $18 \%$ uma vez e $16 \%$ nenhuma vez.

Com base nos resultados obtidos, verificamos que a maioria dos estudantes de odontologia, da universidade privada, caracteriza-se por já ter concluído o segundo grau em escola particular e experenciado o vestibular pelo menos uma vez. Consideramos que este perfil pode motivar a escolha da profissão odontológica, na instituição de caráter privado, ou seja, o desgaste do estudante em freqüentar o “cursinho" e prestar vestibular por várias vezes, em instituições públicas, e por sua vez, a maior facilidade de ingresso na instituição privada. 


\subsubsection{Estudantes que já iniciaram outro curso superior e o principal motivo do abandono do curso superior iniciado}

Observamos que 43 estudantes não iniciaram outro curso superior (86\%); três estão cursando outro curso de nível superior (36\%), três já concluíram outro curso superior (36\%) e um já iniciou, mas abandonou (2\%).

Os principais motivos apontados para o abandono do curso superior iniciado são: $50 \%$ porque se decepcionou com o curso e $50 \%$ porque mudou de opção profissional, sendo que nenhum estudante registrou as opções porque não foi classificado no curso desejado ou porque não foi classificado na universidade desejada ou outro motivo não especificado nas alternativas anteriores.

\subsubsection{Como teve conhecimento do processo seletivo na UNIT e expectativa frente ao curso}

Verificamos que $43 \%$ tiveram conhecimento do processo seletivo por outros estudantes da UNIT; 22\% por folhetos ou cartazes de divulgação; $14 \%$ por outdoor/busdoor; $8 \%$ por professores da UNIT; $8 \%$ por outros meios e $4 \%$ por rádio. Nenhum aluno apontou o jornal e a televisão como forma de conhecimento do processo seletivo.

Quanto às expectativas em relação ao curso observamos que $88 \%$ esperam uma formação profissional voltada para o mercado de trabalho; 6\% esperam uma formação cultural ampla; $2 \%$ uma formação científica voltada para a pesquisa; $2 \%$ outros e $2 \%$ não registraram resposta.

Os resultados demonstram que o interesse do aluno em adquirir uma formação profissional, voltada para o mercado de trabalho, apresenta-se como uma 
expectativa que deva ser motivo de reflexão, quando nos questionamos sobre o modelo odontológico representativo deste mercado de trabalho, para o qual este estudante deseja ser formado. Preocupa-nos a baixa expectativa para uma formação cultural ampla, assim como para a formação científica voltada para a pesquisa, reproduzindo uma cultura odontológica centrada na clínica privada e consultório particular.

Acresce-se a isto outra questão que merece reflexão, e que é objeto desta pesquisa, é sobre o impacto da saúde bucal coletiva na formação do estudante e o quão complexo é este ensino com suas concepções e atribuições junto ao estudante que, em grande parte, pretende conduzir sua formação com base nas demandas do mercado de trabalho.

\subsubsection{Sobre a cultura geral, cursos extracurriculares e prática de esportes do estudante}

Verificamos que $42 \%$ afirmam ler de 3 a 5 livros por ano (não inclui livros escolares); $26 \%$ de 1 a 2 livros; $26 \%$ de 6 a 10 livros; $2 \%$ mais de 10 livros e $4 \%$ nenhum livro.

Obtivemos que $40 \%$ lê jornal ocasionalmente; $28 \%$ lê jornal diariamente; $26 \%$ aos domingos; $2 \%$ não lê e $4 \%$ não registrou resposta.

Observamos que $36 \%$ freqüenta curso de língua estrangeira; $25 \%$ freqüenta cursos de ginástica, dança ou esportes; $25 \%$ freqüenta outros tipos de cursos; $7 \%$ freqüenta curso de música, $3 \%$ de artes e $6 \%$ não registrou resposta.

Verificamos que 35 estudantes praticam algum tipo de esporte (73\%); 13 não praticam esporte (27\%); oito praticam esporte aquático (17\%); oito praticam esporte 
coletivo de campo (17\%); cinco praticam esporte coletivo de quadra (10\%) e 1 pratica atletismo (2\%). Nenhum aluno registrou a opção lutas olímpicas.

Observamos que $60 \%$ têm e manuseia computador; $27 \%$ não têm computador, mas manuseia; $11 \%$ têm computador, mas não manuseia; $2 \%$ não têm e não manuseia e $2 \%$ não registraram resposta.

Com base nos resultados obtidos, mostra mais uma vez, que os estudantes de odontologia vêm de uma classe média alta.

\subsection{SOBRE AS CONTRIBUIÇÕES DO PROJETO DE SAÚDE BUCAL COLETIVA, PARA A FORMAÇÃO DO ESTUDANTE DE ODONTOLOGIA}

Os resultados apresentados a seguir referem-se à visão dos estudantes, sobre cada etapa do Projeto de Saúde Bucal Coletiva, desenvolvido do primeiro ao quarto ano do curso de odontologia.

Porém, vamos iniciar o item caracterizando primeiramente a população de estudantes em cada período do quarto ano e os motivos da escolha da profissão.

Observamos, na Tabela 7, que de uma população de 59 estudantes que atualmente estão cursando o $4^{\circ}$ ano, 51 responderam ao questionário, correspondendo a $86 \%$ do estabelecido para a pesquisa. Participaram um percentual maior de estudantes do sétimo período (96\%), quando comparado com os do oitavo período (77\%). Obtivemos $14 \%$ de estudantes que não responderam ao questionário, sendo que a grande maioria, $12 \%$ não justificou o não comparecimento e estão cursando o oitavo período. Destes, $3 \%$ não estavam presentes ao dia da coleta de dados e $9 \%$ não 
quiseram aguardar o momento da aplicação dos questionários, sem justificativa. Apenas 2\% dos estudantes justificaram o motivo da ausência à pesquisa.

Tabela 7 - Distribuição dos estudantes do sétimo e oitavo períodos do Curso de Odontologia, segundo a participação no questionário aplicado. Uberlândia, 2002

\begin{tabular}{|c|c|c|c|c|}
\hline \multirow{2}{*}{$\begin{array}{l}\text { ESTUDANTES DO CURSO DE } \\
\text { ODONTOLOGIA }\end{array}$} & \multirow{2}{*}{$7^{\circ}$ PERÍODO } & \multirow{2}{*}{$8^{\circ}$ PERÍODO } & \multicolumn{2}{|c|}{ TOTAL } \\
\hline & & & NÚMERO & $\%$ \\
\hline Responderam ao questionário & 27 & 24 & 51 & 86 \\
\hline Não responderam ao & 1 & 7 & 8 & 14 \\
\hline Total & 28 & 31 & 59 & 100 \\
\hline
\end{tabular}

Apesar de alcançarmos uma quantidade significativa de estudantes participando da pesquisa, cabe ressaltar que houve recusa, sem justificativa de um grupo de $12 \%$, que estavam presentes e convidados para o dia da coleta de dados, e optaram por não contribuir com a pesquisa. É necessário refletirmos se esta recusa representa desinteresse pelo assunto, indiferença e opiniões negativas, quanto ao Projeto de Saúde Bucal Coletiva analisado, ou receio em colocar suas opiniões, prevendo futuras represálias, apesar do anonimato ter sido garantido e preservado.

Esta ressalva, justifica-se considerando que um estudante manifestourse, dizendo que: "não queria participar da pesquisa, pois a sua opinião sobre o Projeto era negativa e que os docentes responsáveis pelo mesmo rão iriam gostar." Neste momento, foi reforçado junto ao mesmo a importância de divergências e diferentes opiniões, para o crescimento do Projeto. O referido aluno resolveu participar, desde que garantido o seu anonimato.

Quanto ao sexo, observamos, na Tabela 8, que houve predomínio do sexo feminino para a população estudada, sendo, $68.7 \%$ do sexo feminino e $27.5 \%$ do sexo masculino. 
Tabela 8 - Distribuição dos estudantes do Curso de Odontologia, que responderam aos questionários, segundo o sexo. Uberlândia, 2002

\begin{tabular}{lcc}
\hline \hline SEXO & QUANTIDADE & $\%$ \\
\hline Masculino & 14 & 27.5 \\
Feminino & 35 & 68,7 \\
\hline Total & 51 & 100,0 \\
\hline \hline
\end{tabular}

Silveira \& Cordón (1984), há dezoito anos atrás, em pesquisa intitulada: “A mulher no ensino superior em odontologia no Brasil", encontraram uma população jovem de professores do sexo feminino, solteiras, assistentes, que se dedicavam a odontopediatria e odontologia social e que não tiveram problemas para o seu ingresso nas faculdades, constituindo - se no perfil encontrado na pesquisa.

Werner [1989?], relaciona o aumento da participação feminina na composição da força de trabalho em odontologia com os padrões de trabalho vigente;

"Constante aumento da participação feminina na composição da força de trabalho em odontologia está modificando não só a longevidade da vida ativa dos cirurgiões dentistas como também parece modificar os padrões de trabalho vigentes (trabalhos do meio-expediente, etc.)." (Werner, [1989?] p. 24)

Já discutimos na primeira parte deste capítulo a questão da feminização da força de trabalho na área de saúde, principalmente na medicina e odontologia.

Quanto à idade verificamos pela Tabela 9 que a maioria dos estudantes participantes da pesquisa, ou seja, 56.8\% é jovem, entre 20 a 23 anos, seguidos daqueles entre 24 e 27 anos, com 29.4\%. Nas outras faixas etárias as porcentagens são bem menores. Ocorre predomínio de estudantes entre 20 e 27 anos de idade, ou seja, $86.2 \%$. A idade média correspondeu a 23 anos. 
Tabela 9 - Distribuição dos estudantes, do sétimo e oitavo períodos, do Curso de Odontologia, que responderam aos questionários, segundo a faixa etária, Uberlândia, 2002

\begin{tabular}{lcc}
\hline \hline FAIXA ETÁRIA & $\mathbf{N}^{\mathbf{0}}$ DE ALUNOS & \% \\
\hline 201 1-------1 23 anos & 29 & 56,8 \\
24 1-------1 27 anos & 15 & 29,4 \\
28 1-------1 31 anos & 1 & 2,0 \\
32 1--------1 35 anos & 4 & 7,8 \\
36 1-------1 39 anos & 1 & 2,0 \\
Não identificada & 1 & 2,0 \\
\hline Total & 51 & 100,0 \\
\hline \hline
\end{tabular}

\subsubsection{Sobre os motivos para escolha da carreira odontológica}

“... sempre gostei, cresci vendo meus pais trabalhando.” (Estudante de odontologia 1).

Apresentando agora as respostas a cada pergunta do questionário propriamente dito, contendo 13 questões e um campo aberto para sugestões, dúvidas, críticas e observações, iniciamos pelos motivos determinantes, para a escolha da carreira odontológica. Tendo como finalidade agrupar as causas similares, elaboramos 11 categorias, conforme descrito na Tabela 10, apresentando os motivos em ordem decrescente de importância para a escolha da carreira. 
Tabela 10 - Motivos para a escolha da carreira odontológica, pelos estudantes do curso de odontologia. Uberlândia, 2002

\begin{tabular}{|c|c|c|c|}
\hline GRUPO & CATEgORIAS & FREQÜÊNCIA & $\%$ \\
\hline $1^{\circ}$ & Influência, convivência e tradição familiar/ desejo de criança & 18 & 32 \\
\hline $2^{\circ}$ & $\begin{array}{l}\text { Interesse por curso na área da saúde e saúde bucal (área } \\
\text { biológica) }\end{array}$ & 16 & 28 \\
\hline $3^{\circ}$ & Falta de oportunidade de cursar medicina & 5 & 9 \\
\hline $4^{\circ}$ & $\begin{array}{l}\text { Experiência em áreas similares (auxiliar de consultório dentário, } \\
\text { técnico em prótese e técnico de higiene de dental) }\end{array}$ & 4 & 7 \\
\hline $5^{\circ}$ & $\begin{array}{l}\text { Insatisfação com a área de atuação que estava cursando } \\
\text { anteriormente }\end{array}$ & 3 & 5 \\
\hline $6^{\circ}$ & $\begin{array}{l}\text { Interesse pelas características e habilidades pertinentes a } \\
\text { profissão odontológica: artesanal, artística, estética e minuciosa }\end{array}$ & 3 & 5 \\
\hline $7^{\circ}$ & $\begin{array}{l}\text { Interesse despertado após vivenciar a condição de paciente } \\
\text { odontológico }\end{array}$ & 2 & 4 \\
\hline $8^{\circ}$ & Trabalho social/ Trabalho com pessoas & 2 & 4 \\
\hline $9^{\circ}$ & Liberalidade da profissão odontológica & 1 & 2 \\
\hline $10^{\circ}$ & Caráter assistencialista & 1 & 2 \\
\hline $11^{\circ}$ & $\begin{array}{l}\text { Desgaste em prestar cursos pré-vestibulares/ Não apresenta } \\
\text { motivo especial }\end{array}$ & 1 & 2 \\
\hline & Total* & 56 & 100 \\
\hline
\end{tabular}

* - não corre sponde ao número de estudantes, mas sim ao número de razões apontadas.

A primeira classificação, definida a partir da influência, convivência e tradição transmitida pelos pais, avós, tios e demais parentes, faz parte dos principais motivos, da escolha da carreira, perfazendo $32 \%$ das causas apresentadas. Este motivo é seguido, em $28 \%$ das intenções, relacionadas ao fato do curso ser da área da saúde ou biológicas, sendo que estas duas primeiras razões supracitadas, perfazem $60 \%$ dos motivos apresentados.

Agrupando-se as respostas classificadas em quarto, quinto e sexto lugar temse se um grupo relevante de intenções, que são aquelas referentes a: possuir experiência em áreas similares (auxiliar de consultório dentário, técnico em prótese e técnico de higiene de dental), insatisfação com a área de atuação que estava cursando 
anteriormente, e interesse pelas características e habilidades pertinentes a profissão odontológica, quais sejam: artesanal, artística, estética e minuciosa.

Aparecem como motivos menos mencionados: o interesse despertado após vivenciar a condição de paciente odontológico, o caráter de trabalho social e junto às pessoas, a liberalidade da profissão odontológica, o caráter assistencialista e o desgaste em prestar cursos pré - vestibulares ou o fato de não apresentar motivo especial. É importante mencionar que o terceiro motivo para a escolha da odontologia apresentada por cinco alunos (9\%) refere-se a não oportunidade de cursar a medicina. Este motivo merece reflexão, pois está carregado de frustração.

Cruz \& Silva (1996), identificaram, também, os motivos determinantes para a escolha da carreira odontológica, através de pesquisa realizada com 100 alunos do Curso de Odontologia, da Escola de Alfenas, a partir de duas etapas: na primeira utilizaram a análise de redações e na segunda, tendo como base os 16 motivos mais freqüentes apontados, aplicaram uma escala solicitando aos alunos que numerassem os motivos em ordem decrescente de importância, para a escolha da profissão odontológica. Verificaram três principais motivos:

“(...) a liberalidade da profissão, o fato do curso se dar na área biológica e o retorno financeiro, enquanto a falta de oportunidade de cursar medicina, as pressões familiares e a proximidade da residência familiar com a Instituição de Ensino são apontados como os motivos menos relevantes." (CRUZ \& SILVA, 1996)

Comparando-se os motivos elencados, em cada uma das duas pesquisas, para escolha da profissão odontológica, observa-se que apesar de perfazer-se menos de uma década, apenas seis anos, entre a realização da pesquisa em Alfenas e a pesquisa em Uberlândia, obteve-se motivos diferenciados, talvez influenciados pela conjuntura econômica atual, restrições à liberalidade da profissão, limitações nas possibilidades de atratividade financeira no mercado de trabalho da área 
odontológica, demonstrando tendência de alteração frente à imagem da profissão, conforme demonstrado na Tabela 11.

Tabela 11 - Motivos para escolha da carreira odontológica, segundo classificação em ordem decrescente de importância, realizada pelos estudantes das universidades de Alfenas (1996) e Uberlândia (2002)

\begin{tabular}{|c|c|c|}
\hline \multirow[b]{2}{*}{ CATEgORIAS } & \multicolumn{2}{|c|}{ CLASSIFICAÇÃO DOS MOTIVOS } \\
\hline & $\begin{array}{c}\text { ALFENAS } \\
(1996) \\
\end{array}$ & $\begin{array}{l}\text { UBERLÂNDIA } \\
(\mathbf{2 0 0 2 )} \\
\end{array}$ \\
\hline Influência, convivência e tradição familiar/ desejo de criança & $5^{\mathrm{a}}$ & $1^{\mathrm{a}}$ \\
\hline $\begin{array}{l}\text { Interesse por curso na área da saúde e saúde bucal (área } \\
\text { biológica) }\end{array}$ & $2^{\mathrm{a}}$ & $2^{\mathrm{a}}$ \\
\hline \multicolumn{3}{|l|}{ Falta de oportunidade de cursar medicina } \\
\hline & $4^{\mathrm{a}}$ & $3^{\mathrm{a}}$ \\
\hline $\begin{array}{l}\text { Experiência em áreas similares (Auxiliar de Consultório } \\
\text { Dentário, Técnico em Prótese e Técnico de Higiene de Dental) }\end{array}$ & - & $4^{\mathrm{a}}$ \\
\hline $\begin{array}{l}\text { Insatisfação com a área de atuação que estava cursando } \\
\text { anteriormente }\end{array}$ & - & $5^{\mathrm{a}}$ \\
\hline $\begin{array}{l}\text { Interesse pelas características e habilidades pertinentes a } \\
\text { profissão odontológica: artesanal, artística, estética e minuciosa }\end{array}$ & - & $6^{\mathrm{a}}$ \\
\hline $\begin{array}{l}\text { Interesse despertado após passar pela condição de paciente } \\
\text { odontológico }\end{array}$ & - & $7^{\mathrm{a}}$ \\
\hline Trabalho social/ Trabalho com pessoas & - & $8^{\mathrm{a}}$ \\
\hline Liberalidade da profissão odontológica & $1^{\mathrm{a}}$ & $9^{\mathrm{a}}$ \\
\hline Caráter assistencialista & - & $10^{\mathrm{a}}$ \\
\hline $\begin{array}{l}\text { Desgaste em prestar cursos pré vestibulares/ não apresenta } \\
\text { motivo especial }\end{array}$ & - & $11^{\mathrm{a}}$ \\
\hline Retorno financeiro & $3^{\mathrm{a}}$ & - \\
\hline Proximidade da residência familiar com a Instituição de Ensino & $5^{\mathrm{a}}$ & - \\
\hline
\end{tabular}

De acordo com Teixeira (1995), a odontologia chega ao final do milênio com questões paradoxais e preocupantes para sua manutenção como profissão autônoma, se pensarmos em sua atuação nos países do primeiro mundo. Analisa que nestes países, a odontologia produziu e aplicou o conhecimento e as tecnologias avançadas, eliminando, por exemplo, o problema da cárie, provocando abalos na prática 
profissional e conseqüentemente nos mercados de trabalho, eliminando o principal objeto de trabalho da odontologia. Tal situação não se aplica ao Brasil como país periférico, afirmando que:

"A odontologia se mantém com sua tradicional prática (combate às cáries) assegurando, assim, um mercado de trabalho exclusivo e abundante. A odontologia vive o auge como profissão, com elevado status e prestígio social. $O$ volume de escolas, alunos e altas taxas de demandas pelos cursos atestam esse sucesso profissional".(TEIXEIRA, p. 189, 1995).

Contudo, Teixeira (1995) antevê e anuncia que considera que o sucesso profissional apontado é um sucesso baseado no atendimento a camadas sociais privilegiadas. 'O sucesso da odontologia é o sucesso do profissional liberal, da odontologia liberal." Assim, como contraponto a este mercado de trabalho, dito como abundante, destaca o crescente aumento do número de estudantes matriculados nos cursos de graduação em odontologia, assim como ocorreu com a medicina a partir do final da década de 1960, provocando um expressivo crescimento do contingente profissional habilitado para a prática. Ressaltando a seguinte informação:

"Hoje, o país conta com mais de 100 mil odontólogos. Sua distribuição, no entanto, acontece de forma desigual pelas regiões, provocando uma concentração nas regiões sudeste e sul." (TEIXEIRA, p.190, 1995)

Não podemos, também, deixar de citar neste contexto, contrapondo ao mercado de trabalho citado como abundante para a odontologia, que de acordo com o Anuário da Organização Mundial de Saúde (OMS), de 1995 - "O índice de cáries no Brasil não se encontra entre os maiores do mundo, diferentemente do que vem sendo divulgado entre nós (O BRASIL... 1996).”

Vale ressaltar, que apesar do Brasil não estar mais classificado como campeão mundial de cárie dental, é evidente que esta situação não se apresenta de forma homogênea entre as regiões brasileiras e interclasses sociais. As profundas 
desigualdades presentes, nos centros urbanos e nas diferentes regiões do país, torna m difíceis as análises desta tendência de queda da doença cárie, nacionalmente. E, infelizmente, não podemos associar de forma radical - queda do índice de cárie com acesso a serviços odontológicos de forma universal, equânime e integral, sob a perspectiva da ausência dos desconfortos causados pelas doenças bucais e com um autêntico sorriso saudável.

Contudo, mesmo reconhecendo estas limitações podemos, hoje, falar sobre queda de cárie no Brasil, tendo em vista a comparação entre o primeiro Levantamento Epidemiológico, de âmbito nacional na área de saúde, realizado em 1986, pelo Ministério da Saúde e o Levantamento Epidemiológico realizado, também, pelo Ministério da Saúde, promovido em 1996, com o apoio do Conselho Federal de Odontologia. Os resultados mostram que; "O índice CPOD (dentes cariados, perdidos e obturados), que em 1986 - no último censo Epidemiológico era de 6,67, caiu para 3,06, em 1996, numa redução de cerca de 54\%" (Levantamento... 1997).

Embora Pinto (1997), questione este último levantamento, visto que a amostra utilizada é considerada sem critério, não aleatória (não probabilística), significando que somente uma extraordinária coincidência poderia fazer com que seus resultados representem a realidade, a redução do índice de cárie dental já vinha sendo constatado em trabalhos isolados, através de várias pesquisas e resultados encontrados em pequenos municípios, com ou sem tradição de serviços e programas de saúde bucal, como "Icó no Ceará ou Tapiraí, no interior paulista, seja em grandes cidades como Goiânia, Campinas, São José dos Campos, Santos, entre outras" (NARVAI, 1996). 
Consideramos que os levantamentos epidemiológicos realizados pelo Ministério da Saúde, em 1986 e 1996, continuam tendo sua importância, pois constituem-se nos únicos referenciais, de âmbito nacional, fornecendo indicadores para o setor odontológico, porém, não são suficientes para caracterizar a situação das condições atuais de saúde bucal do país e dos estados.

Assim, esperamos que o anunciado "Projeto das Condições de Saúde Bucal da População Brasileira no ano 2000 - SB 2000 (MINITÉRIO DA SAÚDE, 2002), originado a partir das discussões da Área Técnica de Saúde Bucal do Ministério da Saúde, desde 1998, amplie e atualize a base de dados em saúde bucal no país e contribua, de forma efetiva, contando com uma base metodológica uniforme

Segundo informações disponíveis no site oficial da Área Técnica de Saúde Bucal do Ministério da Saúde, o Saúde Bucal - SB 2000 encontra-se, ao final do ano de 2002, em fase de espera para consolidação dos trâmites burocráticos no sentido de que os recursos financeiros necessários para a consecução da pesquisa sejam efetivamente liberados, considerando que toda a documentação necessária para treinamento (manuais) já está pronta, "software" para tabulação dos dados, plano amostral delineado e municípios e setores censitários também já conduzido. (MINITÉRIO DA SAÚDE, 2002).

Nesta perspectiva, a liberalidade da profissão odontológica, no Brasil, encontra-se comprometida em conseqüência não só do excesso de contingente profissional no mercado de trabalho, mas, também, como tendência ao controle e eliminação do problema da cárie no país, provocando abalos na prática profissional e conseqüentemente nos mercados de trabalho, eliminando o principal objeto de 
trabalho da odontologia, conforme observado por Teixeira (1995) em relação aos países desenvolvidos.

Por outro lado, é preciso compreender que a odontologia não se resume ao enfrentamento da doença cárie. Nesta perspectiva, percebemos como estamos distante de combater e tentar controlar os demais problemas de alcance coletivo da odontologia, que nos países em desenvolvimento e alto consumidores de açúcar, conforme demonstra Pinto (1996), fazem parte do grupo de doenças que constitui risco para saúde bucal, procedendo a cárie dental, como a doença periodontal, as más-oclusões, o câncer de bucal, a fluorose e o lábio leporino e as fendas palatinas.

Ainda, com base na comparação visualizada na Tabela 6, verificamos que o motivo - "Interesse pela área da saúde ou biomédicas", constitui-se na segunda razão principal, para alunos de diferentes universidades e municípios.

Para os alunos da Universidade de Alfenas os principais motivos correspondem à liberalidade da profissão odontológica, em 1996, enquanto que para os alunos do Centro Universitário do Triângulo os primeiros motivos são de natureza de influência e tradição familiar. E, novamente, o terceiro motivo, para os alunos de diferentes universidades analisadas, em épocas distintas, são diferentes. Sendo que para Alfenas apresenta-se o retorno financeiro e para Uberlândia, falta de oportunidade de cursar medicina.

Os resultados obtidos em nossa pesquisa demonstram que a convivência, a partir dos cotidianos familiares, acompanhando as atividades dos pais ou parentes aparece com freqüência destacada, conforme Tabelas 10 e 11. As respostas “... sempre quis, desde criança brincava de dentista...” ou “... sempre gostei, cresci vendo meus pais trabalhando", surgem como falas comuns, para a justificativa da 
escolha e desenvolvimento da afinidade pela profissão odontológica. Fato que merece destaque, diz respeito aos relatos dos estudantes, em que a escolha foi potencializada por “pressão dos pais”, determinando a escolha da profissão.

No entanto, é importante observar que a média de idade dos alunos que participaram da pesquisa gira em torno de 23 anos, sendo assim o modelo odontológico que influenciou sua escolha profissional, provavelmente baseia-se no modelo centrado no "atendimento no consultório particular", pouco acessível à população em geral e centrado nos procedimentos clínicos restauradores. Prática esta predominante na década em que os pais e parentes os influenciaram e que continua vigente até os dias atuais, conforme afirma Zanetti, 1999:

"Foi do alto de sua hegemonia que os cirurgiões dentistas, ao longo do século, enfatizaram a esfera privada como espaço privilegiado para a organização de suas práticas. Daí, no mercado, a odontologia fez seu canteiro e produziu as suas mais belas flores."

Entretanto, Zanetti (1999) complementa colocando que o mercado de serviços curativos de massa vem passando por um processo de mudanças estruturais profundas e esgotando-se. Votaremos a esta questão, quando o aluno é questionado sobre a área de atuação que pretende atuar, onde observamos alta opção por área clínica restauradora, enfatizada pela esfera privada.

Começa delinear-se, neste momento, de análise dos resultados, uma discussão crucial, abordada por Teixeira (1995): “como a profissão tornará seus serviços acessíveis à população em geral e quando terá efetivamente consolidado sua praticidade social?" Considerando que, conforme tem demonstrado os resultados desta pesquisa, a presença de enorme contradição entre o modelo de atenção odontológica que influenciou a escolha do estudante do Centro Universitário do Triângulo, a partir do modelo vigente na convivência familiar, hegemônico no 
mercado de trabalho, versus a possível adoção de um modelo odontológico alternativo, ou seja, a saúde bucal coletiva.

$\mathrm{Na}$ experiência de ensino destes alunos, este modelo encontra-se em construção, caracterizado pelo Projeto Pedagógico defendido pelo Projeto de Saúde Bucal Coletiva, há dois anos fazendo parte do seu aprendizado acadêmico. O Projeto tem como finalidade, a inserção social do aluno/comunidade, sob a perspectiva das ações de promoção, prevenção e recuperação da saúde, aplicadas em abordagens de alcance coletivo, baseando-se nos avanços da epidemiologia e da cariologia, na busca da humanização do ensino superior. Prioriza o acesso a atenção odontológica de forma equânime, através da utilização de critérios de risco às doenças bucais mais prevalentes, utilizando a estratégia do "Controle Epidemiológico da Cárie Dentária", (SÃO PAULO, 2001) possibilitando identificar parcelas da população que necessitam de cuidados prioritariamente.

Os motivos para escolha profissional representados pelas "Experiência em áreas similares (auxiliar de consultório dentário, técnico em prótese e técnico de higiene de dental)" e "Interesse por curso na área da saúde (área das ciências biológica)", demonstram uma decisão do estudante de odontologia mais própria e, aparentemente mais amadurecida.

Chama a atenção o fato das características intrínsecas da profissão odontológica, sob a perspectiva de constituir-se em área social e um trabalho que exige habilidades artesanais, artísticas e estéticas e lidar com pessoas, também não aparece como significativo. Demonstrando falta de conhecimento mais aprofundado do significado da profissão no conjunto da sociedade. 
Ambas as categorias, "Insatisfação com a área que cursava anteriormente" e "Experiência em áreas similares", representado 12\% das respostas obtidas para escolha da profissão, é acompanhada por um percentual de $41 \%$ dos alunos, na faixa etária entre 24 a 36 anos de idade, que pode justificar a demonstração de maior maturidade na escolha da profissão, considerando que decidiu partir para outra profissão, após vivenciar o curso básico de outras áreas de nível de escolaridade superior, permitindo provavelmente maior discernimento, conhecimento e convívio com práticas cotidianas do objeto da odontologia.

O caráter assistencialista, pautado pela atenção odontológica voltada para comunidades socialmente excluídas, de forma caritativa, centrada em um cunho assistencialista, aparece em apenas $2 \%$ dos relatos dos estudantes expressado em frases do tipo: "Sempre quis participar da saúde das pessoas e trabalhar com pessoas carentes.”

No geral, através das respostas sobre os motivos da escolha da profissão inferimos que os estudantes de odontologia têm pouca compreensão do caráter de responsabilidade social da profissão.

Passamos agora a apresentar os resultados encontrados sobre a percepção dos estudantes de odontologia em relação às contribuições e limitações, de cada etapa, do Projeto de Saúde Bucal Coletiva, desenvolvido do primeiro ao quarto ano do Curso de Odontologia, para em seguida realizarmos a discussão dos mesmos de forma interligada, permitindo uma análise do conjunto de atividades de ensino propostas pelo Projeto. 


\subsubsection{A Contribuição do Projeto Saúde Bucal Coletiva - Justificativas dos estudantes de odontologia}

\subsubsection{Resultados da primeira etapa do Projeto Saúde Bucal Coletiva}

"Ir aos bairros, cadastrar as pessoas, porque lá você tem contato com a realidade delas." (Estudante de odontologia 2).

A $1^{\text {a }}$ etapa do Projeto Saúde Bucal Coletiva é desenvolvida tendo como fundamento duas disciplinas básicas denominadas: Odontologia Coletiva 1/ Programa de Saúde da Família e Ciências Sociais Aplicadas à Saúde, durante o segundo período do curso de odontologia.

Dos 51 estudantes, 49 (95\%) consideraram que houve contribuição para sua formação e 2 estudantes (5\%) consideram que a primeira etapa não contribuiu para sua formação.

As justificativas para a não contribuição foram: as características operacionais do Projeto no bairro e o caráter social da proposta, alegando que - “... tinha que andar no sol quente e suportar cheiro de urina no sofá”, má receptividade das famílias, ações limitadas ao cadastramento e atividades consideradas cansativas. Uma estudante explicou que o fato da mesma estar gestante dificultou a execução das atividades práticas.

Para apresentação das justificativas sobre os aspectos que contribuíram para a formação do estudante de odontologia, consideramos sete categorias principais, conforme as razões em ordem decrescente de importância, demonstradas na Tabela 12. 
Tabela 12 - Justificativas da contribuição da primeira etapa do Projeto Saúde Bucal Coletiva, na formação do estudante de odontologia, segundo classificação em ordem decrescente de importância. Uberlândia, 2002

\begin{tabular}{|c|c|c|c|}
\hline GRUPO & CATEgORIAS & FREQÜÊNCIA & $\%$ \\
\hline $1^{\mathrm{o}}$ & $\begin{array}{l}\text { Identificação, integração e sensibilização com a situação sócio, } \\
\text { cultural, econômica e de saúde da comunidade de "baixa renda", } \\
\text { diferente de sua realidade, que necessitam de melhores condições } \\
\text { de vida, informação e acesso/ Primeiro contato com aspectos da } \\
\text { saúde pública e a sociologia. }\end{array}$ & 33 & 52 \\
\hline $2^{\circ}$ & $\begin{array}{l}\text { Primeiro contato com serviço público, com a rede SUS/ } \\
\text { Compreensão do papel e dos serviços desenvolvidos pelo } \\
\text { odontólogo/ Conhecimento do acesso do usuário a rede SUS }\end{array}$ & 12 & 19 \\
\hline $3^{\circ}$ & $\begin{array}{l}\text { Contatos realizados durante as visitas domiciliares, relacionando- } \\
\text { se com futuros pacientes, onde antes não havia atenção primária } \\
\text { em odontologia/ Aprender abordar as pessoas da família, } \\
\text { facilitando a desinibição do estudante de odontologia. }\end{array}$ & 11 & 17 \\
\hline $4^{\circ}$ & $\begin{array}{l}\text { Despertou sentimento contraditório de utilidade/ impotência, no } \\
\text { estudante de odontologia, ao levar informações adquiridas na } \\
\text { universidade/ O estudante não ficar restrito a visão teórica. }\end{array}$ & 4 & 6 \\
\hline $5^{\circ}$ & Caráter assistencialista/ gratificação em atender pessoas carentes & 1 & 2 \\
\hline $6^{\circ}$ & $\begin{array}{l}\text { Conhecimento do estudante de odontologia sobre saúde geral e } \\
\text { higiene }\end{array}$ & 1 & 2 \\
\hline $7^{\circ}$ & Contribuição para planejamento da intervenção na comunidade & 1 & 2 \\
\hline & Total* & 63 & 100 \\
\hline
\end{tabular}

Com base nos resultados obtidos, para a primeira etapa do Projeto, verificamos que as principais justificativas de contribuição relacionam-se com os seguintes aspectos: identificação, integração e sensibilização com a situação sócio, cultural, econômica e de saúde da comunidade de "baixa renda", representando o primeiro contato com aspectos da saúde pública, a sociologia, o serviço público, assim como o acesso do usuário a rede SUS; a compreensão do papel e dos serviços desenvolvidos pelo odontólogo, os contatos realizados durante as visitas domiciliares, relacionando-se com futuros pacientes, onde antes não havia atenção primária em odontologia e o aprendizado da abordagem apropriada as pessoas da família, facilitando a desinibição do estudante de odontologia. 


\subsubsection{Resultados da segunda etapa do Projeto Saúde Bucal Coletiva}

"Aprendi realizar o tratamento preventivo das crianças, conforme sua classificação de risco." (Estudante de odontologia 3).

A segunda etapa do Projeto Saúde Bucal Coletiva é desenvolvida tendo como fundamento a disciplina básica denominada Odontologia Coletiva 1l, durante o terceiro período do curso de odontologia. Para esta etapa do Projeto, 50 estudantes de odontologia (98\%) consideraram que houve contribuição para sua formação e um estudante manifestou que não contribuiu (2\%).

Apenas um estudante, no conjunto dos pesquisados considerou esta etapa do Projeto como não contributiva para sua formação, justificando que não gosta de atender crianças, por isso não considerou válido o trabalho desenvolvido pela disciplina.

Consideramos que esta justificativa representa uma visão imatura do estudante, sobre o processo de ensino - aprendizagem, considerando a necessidade intrínseca da profissão odontológica, em aproximar-se de diferentes faixas etárias, assim como pode reproduzir um dilema atual na área da saúde de incentivo a especialização precoce.

Em seguida, na Tabela 13, categorizamos as justificativas para a contribuição da segunda etapa do Projeto de Saúde Bucal Coletiva, sob a percepção do estudante de odontologia. 
Tabela 13 - Justificativa da contribuição da segunda etapa do Projeto Saúde Bucal Coletiva, na formação do estudante de odontologia, segundo classificação em ordem decrescente de importância. Uberlândia, 2002

\begin{tabular}{|c|c|c|c|}
\hline GRUPO & CATEGORIAS & FREQÜÊNCIA & $\%$ \\
\hline $1^{\mathrm{o}}$ & $\begin{array}{l}\text { Primeiro contato prático com aspectos ligados à odontologia } \\
\text { coletiva (dentição, cárie, risco de cárie, placa, tártaro, utilização } \\
\text { de métodos preventivos de orientação, higienização e } \\
\text { fluorterapia, realização de exames, diagnóstico, epidemiologia, } \\
\text { avaliação em saúde) e com as necessidades das crianças de } \\
\text { diferentes realidades. }\end{array}$ & 26 & 51 \\
\hline $2^{\circ}$ & $\begin{array}{l}\text { Aprendizado sob aspectos do primeiro contato, atendimento e } \\
\text { relacionamento com crianças/ troca de conhecimentos. }\end{array}$ & 10 & 19 \\
\hline $3^{\circ}$ & $\begin{array}{l}\text { Percepção das condições da comunidade e da falta de cuidado } \\
\text { bucal das crianças/ Conhecimento das dificuldades da profissão/ } \\
\text { humanização do estudante }\end{array}$ & 6 & 12 \\
\hline $4^{\mathrm{o}}$ & $\begin{array}{l}\text { Possibilidade de intervenção efetiva direcionada na escola/ A } \\
\text { escola apresenta mais estrutura para atuação, quando comparada } \\
\text { com o domicílio/ maior valorização do trabalho pela comunidade }\end{array}$ & 3 & 6 \\
\hline $5^{\circ}$ & $\begin{array}{l}\text { Conciliar teoria e prática/ Continuar praticando o que estava } \\
\text { aprendendo na teoria, considerando que já tinha tido um primeiro } \\
\text { contato./ Adaptação à realidade }\end{array}$ & 3 & 6 \\
\hline $6^{\circ}$ & Enfatizar a prevenção para evitar perda precoce da dentição & 2 & 4 \\
\hline $7^{\circ}$ & $\begin{array}{l}\text { Desenvolveu habilidades para ensinar a criança sobre saúde } \\
\text { bucal e outros temas ligados a prevenção }\end{array}$ & 1 & $\underline{2}$ \\
\hline & Total & 51 & 100 \\
\hline
\end{tabular}

Observando os resultados obtidos, para a segunda etapa do Projeto, verificamos que as principais justificativas de contribuição relacionam-se com: primeiro contato prático com aspectos ligados à odontologia coletiva (dentição, cárie, risco de cárie, placa, tártaro, utilização de métodos preventivos de orientação, higienização e fluorterapia, realização de exames, diagnóstico, epidemiologia, avaliação em saúde, dentre outros) e com as necessidades das crianças de diferentes realidades; o aprendizado sob aspectos do primeiro contato, atendimento e relacionamento com crianças, a troca de conhecimentos com a comunidade escolar e a percepção das condições da comunidade; identificação da falta de cuidado bucal das crianças, o conhecimento das dificuldades da profissão e a humanização do estudante de odontologia. 


\subsubsection{Resultados da terceira etapa do Projeto Saúde Bucal Coletiva}

"Ir aos domicílios porque lá havia a possibilidade de ampliar a informação... Estarmos trabalhando com as famílias, através do diálogo e de ações preventivas e curativas com bons resultados..." (Estudante de odontologia 4).

A terceira etapa do Projeto Saúde Bucal Coletiva é desenvolvida tendo como fundamento a disciplina básica denominada Orientação Profissional 1 , durante 0 quarto período do curso de odontologia. Para esta etapa do Projeto, obtivemos 39 estudantes de odontologia (78\%) que consideraram ter havido contribuição para sua formação e 12 estudantes (22\%) consideraram que não contribuiu.

Observamos que $22 \%$ das justificativas para a não contribuição foram: o desinteresse de algumas famílias pela atenção preventiva e dificuldades operacionais não coincidindo o horário das visitas domiciliares, com a disponibilidade das famílias em receber os estudantes de odontologia. Apontaram, também a repetição das atividades práticas realizadas, anteriormente, no segundo período. Outro aspecto levantado foi o fato de constituir-se em uma atividade com pouca eficácia para a comunidade. $\mathrm{O}$ fato de o estudante deparar-se com a falta de recursos das famílias e as atividades serem consideradas de pouca resolutividade, sob a percepção do aluno, também, apareceram como justificativas para a não contribuição da terceira etapa do Projeto, conforme demonstrado na Tabela 14. 
Tabela 14 - Justificativas da não contribuição da terceira etapa do Projeto Saúde Bucal Coletiva, na formação do estudante de odontologia, segundo classificação em ordem decrescente de importância. Uberlândia, 2002.

\begin{tabular}{|c|c|c|c|}
\hline GRUPO & CATEgORIAS & FREQÜÊNCIA & $\%$ \\
\hline $1^{\mathrm{o}}$ & $\begin{array}{l}\text { Desinteresse das Famílias pela atenção preventiva/ dificuldades } \\
\text { no contato com as famílias (não as encontravam no domicílio, no } \\
\text { horário das visitas)/ Falta de recursos das famílias/necessidade de } \\
\text { reorganização da operacionalização do Projeto. }\end{array}$ & 6 & 50 \\
\hline $2^{\circ}$ & $\begin{array}{l}\text { Repetição da atividade prática realizada, durante o segundo } \\
\text { período/ não acrescentou nada/ pouca eficácia para a } \\
\text { comunidade. }\end{array}$ & 5 & 42 \\
\hline \multirow[t]{2}{*}{$3^{\circ}$} & As atividades desenvolvidas não resultaram em ações práticas & 1 & 8 \\
\hline & Total & 12 & 100 \\
\hline
\end{tabular}

Entretanto, $78 \%$ das justificativas de contribuição da terceira etapa, para a formação do aluno distribuem-se nas seguintes categorias, conforme Tabela 15 .

Tabela 15 - Justificativa da contribuição da terceira etapa do Projeto Saúde Bucal Coletiva, na formação do estudante de odontologia, segundo classificação em ordem decrescente de importância. Uberlândia, 2002

\begin{tabular}{|c|c|c|c|}
\hline GRUPO & CATEGORIAS & FREQÜÊNCIA & $\%$ \\
\hline $1^{\mathrm{o}}$ & $\begin{array}{l}\text { Conhecimento e noção da realidade da população, diferente da } \\
\text { vivenciada pelo estudante/ reconhecer que a saúde bucal não é } \\
\text { uma prioridade para as famílias/desenvolvimento de práticas } \\
\text { preventivas e reconhecimento de casos odontológicos. }\end{array}$ & 17 & 43 \\
\hline $2^{\circ}$ & $\begin{array}{l}\text { Despertar as famílias sobre a prevenção / proposta de ação } \\
\text { continuada - estudante fornecendo retorno às famílias/ } \\
\text { possibilidade de encaminhamentos. }\end{array}$ & 8 & 20 \\
\hline $3^{\circ}$ & $\begin{array}{l}\text { Aprender a lidar com outra classe social e com as famílias (não } \\
\text { apenas com as crianças)/ noção de humanidade e solidariedade }\end{array}$ & 6 & 15 \\
\hline $4^{\mathrm{o}}$ & $\begin{array}{l}\text { Contribuiu, mas foi frustrante pela não possibilidade de ações } \\
\text { efetivas/sentimento de invasão de privacidade das famílias. }\end{array}$ & 3 & 7 \\
\hline $5^{\circ}$ & $\begin{array}{l}\text { Contribuiu com o conhecimento social/ Limitado na área } \\
\text { odontológica, considerando precariedade de recursos e não } \\
\text { garantia de acompanhamento posterior. }\end{array}$ & 1 & 3 \\
\hline $6^{\circ}$ & $\begin{array}{l}\text { Identifica que esta ampliando o acesso da população de baixa } \\
\text { renda. }\end{array}$ & 1 & 3 \\
\hline $7^{\circ}$ & $\begin{array}{l}\text { Identifica que neste período o estudante tem mais conhecimento } \\
\text { para contribuir com orientações e tratamento. }\end{array}$ & 1 & 3 \\
\hline $8^{\circ}$ & Aprendeu com a parte teórica da disciplina & 1 & 3 \\
\hline $9^{\circ}$ & Não recorda se contribuiu & 1 & 3 \\
\hline & Total * & 63 & 100 \\
\hline
\end{tabular}

* não se refere ao total de alunos, mas ao total das justificativas apresentadas. 
Observando os resultados obtidos, para a terceira etapa do Projeto, verificamos que as principais justificativas de contribuição relacionam-se com as seguintes questões: conhecimento e noção da realidade da população, diferente da vivenciada pelo estudante; reconhecimento de que a saúde bucal não é uma prioridade para as famílias; desenvolvimento de práticas preventivas e reconhecimento de casos odontológicos; despertar as famílias sobre a prevenção; fazer parte de uma proposta de ação continuada - estudante fornecendo retorno às famílias; possibilidade de encaminhamentos; aprender a lidar com outra classe social e com as famílias (não apenas com as crianças) e noção de humanidade e solidariedade.

\subsubsection{Resultados da quarta etapa do Projeto Saúde Bucal Coletiva}

"Identifiquei-me com o programa preventivo da creche... Serviu para verificar que a criança na pré escola quase não tem cárie e se orientados não irão manifestar a doença...” (Estudante de odontologia 5).

A quarta etapa do Projeto Saúde Bucal Coletiva é desenvolvida tendo como fundamento a disciplina básica denominada Orientação Profissional 1l, durante o quinto período do curso de odontologia. Para esta etapa do Projeto, obtivemos 45 estudantes de odontologia (89\%) considerando que houve contribuição para sua formação e quatro estudantes (8\%) considerando que não contribuiu, sendo que dois não cursaram a disciplina (4\%).

Com base nos resultados obtidos, observamos que $8 \%$ das justificativas, para a não contribuição, corresponderam ao fato de considerarem inviável atuar com crianças da creche, por serem pequenas, dificultando a execução de procedimentos 
preventivos e assimilação dos conhecimentos sobre autocuidados em odontologia. Consideraram que as atividades ficaram limitadas a - "brincar com as crianças, pois as mesmas não abriam a boca”. Alegaram que executaram atividades repetitivas, quando comparadas com as desenvolvidas na escola, em outra etapa do Projeto, tornando-se uma atividade cansativa e difícil. Esta afirmação merece ser olhada de forma especial, pois aparece como uma necessidade da organização dos conteúdos neste Projeto.

Em contraposição, a estes aspectos considerados negativos pelo estudante de odontologia, $88 \%$ das justificativas de contribuição da quarta etapa, para a formação do aluno distribuíram-se nas seguintes categorias, conforme Tabela 16.

Tabela 16 - Justificativa da contribuição da quarta etapa do Projeto Saúde Bucal Coletiva, na formação do estudante de odontologia, segundo classificação em ordem decrescente de importância. Uberlândia, 2002

\begin{tabular}{|c|c|c|c|}
\hline GRUPO & CATEGORIAS & FREQÜÊNCIA & $\%$ \\
\hline $1^{\circ}$ & $\begin{array}{l}\text { Desenvolvimento de ações preventivas com crianças na faixa } \\
\text { etária de } 0 \text { a } 6 \text { anos de idade/aprendizagem em lidar com } \\
\text { crianças menores (experiência nova), desprivilegiadas } \\
\text { economicamente e de atenção e carinho/desenvolver "tolerância", } \\
\text { no atendimento à criança. }\end{array}$ & 24 & 55 \\
\hline $2^{\circ}$ & $\begin{array}{l}\text { Percepção das dificuldades do atendimento à criança de menor } \\
\text { idade/ relações com outras disciplinas/ desenvolvimento de } \\
\text { técnicas de reforço com a criança para criação dos hábitos de } \\
\text { higiene. }\end{array}$ & 6 & 14 \\
\hline $3^{\circ}$ & $\begin{array}{l}\text { Receptividade das crianças/ Boa estrutura para des envolvimento } \\
\text { das atividades solicitadas. }\end{array}$ & 4 & 9 \\
\hline $4^{\mathrm{o}}$ & $\begin{array}{l}\text { Desenvolvimento ações específicas voltadas para bebês (limpeza } \\
\text { da dentição com gaze) - novo aprendizado/ Orientações } \\
\text { preventivas para as "tomadeiras de conta" das crianças. }\end{array}$ & 4 & 9 \\
\hline $5^{\circ}$ & $\begin{array}{l}\text { Verificação do fato de que a criança da pré-escola sendo bem } \\
\text { orientada, não manifestará as doenças bucais mais comuns/ } \\
\text { demonstração da importância do odontólogo.. }\end{array}$ & 3 & 7 \\
\hline $6^{\circ}$ & $\begin{array}{l}\text { Reafirmação do sentimento de atuar profissionalmente com } \\
\text { crianças (odontopediatria). }\end{array}$ & 2 & 4 \\
\hline $7^{\circ}$ & Contribuição para a formação do ser humano. & 1 & 2 \\
\hline & Total* & 44 & 100 \\
\hline
\end{tabular}

* - não corresponde ao número de estudantes, mas sim a número de contribuições apontadas. 
Os resultados obtidos, para a quarta etapa do Projeto, demonstram que as principais justificativas de contribuição estão relacionadas com os seguintes aspectos: desenvolvimento de ações preventivas, com crianças na faixa etária de zero a seis anos de idade; aprendizagem em lidar com crianças menores (considerada uma nova experiência), as quais são desprivilegiadas economicamente e de atenção e carinho; desenvolver "tolerância" e percepção das dificuldades do atendimento à criança de menor idade; relações com outras disciplinas e desenvolvimento de técnicas de reforço com a criança, para criação dos hábitos de higiene.

\subsubsection{Resultados da quinta etapa do Projeto Saúde Bucal Coletiva}

"A prática na clínica porque você aprende de tudo um pouco, ficando mais preparado. Na Clínica você está tratando." (Estudante de odontologia 6 ).

A quinta etapa do Projeto Saúde Bucal Coletiva é desenvolvida tendo como fundamento as disciplinas clínicas denominadas Programas Odontológicos Coletivos 1 e ll, durante os sétimo e oitavo períodos do curso de odontologia, correspondendo às aulas práticas no Ciclo Clínico. Para esta etapa do Projeto, todos os 51 estudantes de odontologia foram unânimes em apontar que houve contribuição para sua formação.

Assim, as justificativas de contribuição da quinta etapa, para a formação do estudante distribuem - se em quatro grandes categorias, demonstradas na Tabela 17. 
Tabela 17 - Justificativa contribuição da quinta etapa do Projeto Saúde Bucal Coletiva, na formação do estudante de odontologia, segundo classificação em ordem decrescente de importância. Uberlândia, 2002

\begin{tabular}{|c|c|c|c|}
\hline GRUPO & CATEgorias & FREQÜÊNCIA & $\%$ \\
\hline $1^{\circ}$ & $\begin{array}{l}\text { Experiência prática da saúde bucal coletiva (intervenção clínico } \\
\text { restauradora) - contato direto com o paciente/ colocar em } \\
\text { prática o que foi planejado/ possibilitou visão ampla de todo o } \\
\text { Projeto e de vários casos odontológicos/ aprendeu a lidar com o } \\
\text { atendimento à criança de forma criativa e mais ágil/ } \\
\text { relacionamento da teoria com a prática/ desenvolvimento de } \\
\text { habilidades, das técnicas de dentística, autonomia de } \\
\text { atendimento, alternativas de tratamento/ conhecimento de } \\
\text { material odontológico/ lidando com urgências odontológicas/ } \\
\text { aprendendo aplicar odontologia sob a perspectiva da saúde } \\
\text { pública. }\end{array}$ & 46 & 90 \\
\hline $2^{o}$ & $\begin{array}{l}\text { Conscientização do estudante de odontologia em associar a } \\
\text { prevenção e o tratamento clínico restaurador/ importância da } \\
\text { continuidade da atenção odontológica iniciada no terceiro } \\
\text { período com as crianças da escola. }\end{array}$ & 3 & 6 \\
\hline $3^{\circ}$ & $\begin{array}{l}\text { Possibilitou o atendimento de crianças que necessitam da clínica } \\
\text { odontológica (equanimidade). }\end{array}$ & 1 & 2 \\
\hline $4^{\mathrm{o}}$ & $\begin{array}{l}\text { Consegue resolver problemas que não poderiam ser resolvidos } \\
\text { nas visitas às famílias. }\end{array}$ & 1 & 2 \\
\hline & Total & 51 & 100 \\
\hline
\end{tabular}

Os resultados obtidos, para a quinta e última etapa do Projeto, demonstraram que as principais justificativas de contribuição estão relacionadas com os seguintes aspectos: possibilitou experiência prática da saúde bucal coletiva (intervenção clínico restauradora) - contato direto com o paciente; colocou em prática o que foi planejado; permitiu visão ampla de todo o Projeto e de vários casos odontológicos; aprendeu a lidar com o atendimento à criança de forma criativa e mais ágil; relacionou a teoria com a prática; desenvolveu habilidades técnicas de dentística; autonomia de atendimento; alternativas de tratamento; conhecimento de materiais odontológicos diversificados; lidou com urgências e aprendeu aplicar odontologia, sob a perspectiva da saúde pública. 
Por fim agrupando todas as respostas dos estudantes quanto as cinco etapas do Projeto de Saúde Bucal Coletiva, obtivemos um índice de aprovação na ordem de $92 \%$, e $8 \%$ de respostas que consideraram que não houve nenhuma contribuição, conforme a Figura 6.

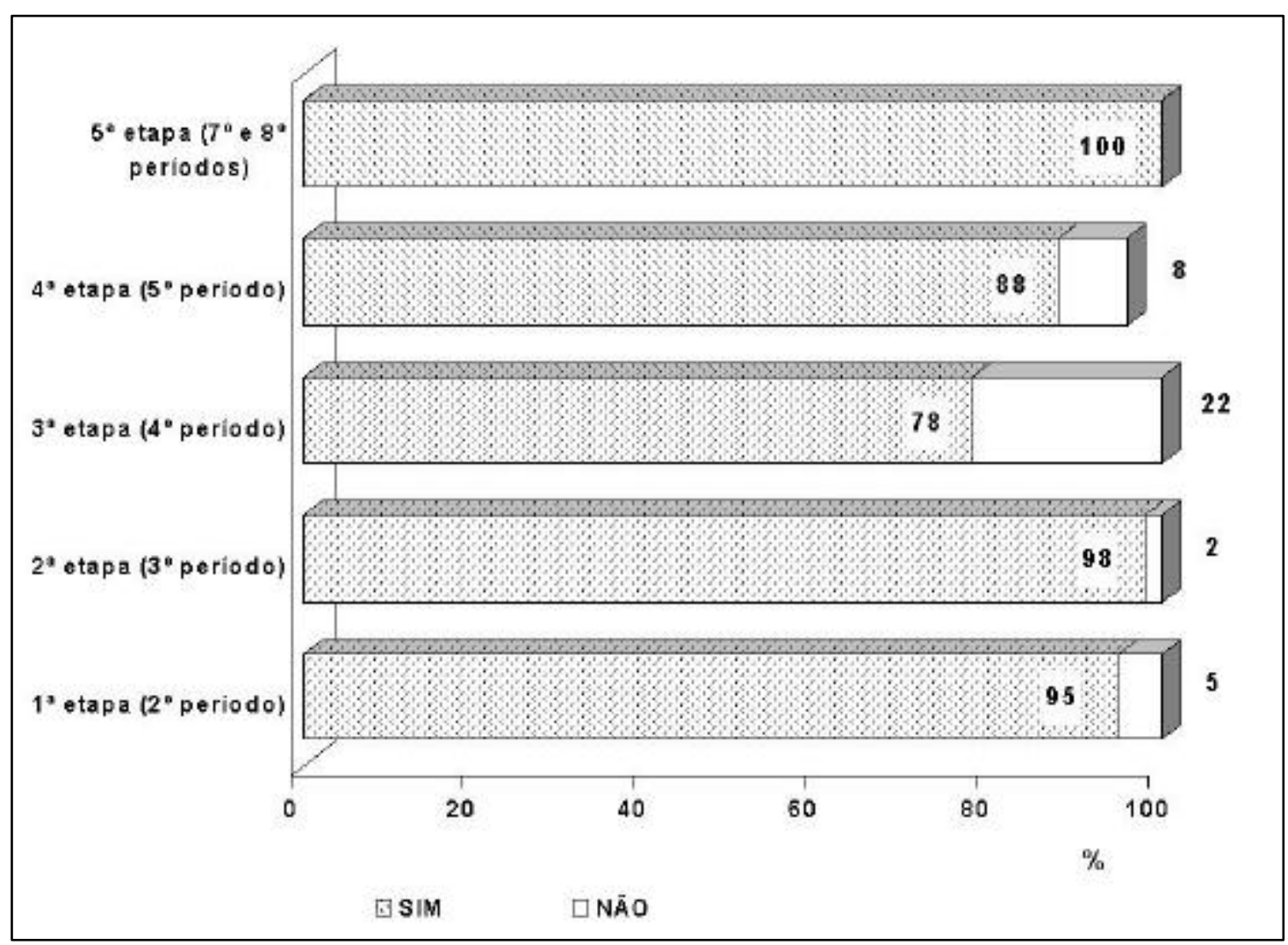

Figura 6 - Contribuição do Projeto Saúde Bucal Coletiva para a formação do estudante de odontologia, conforme as etapas do segundo ao oitavo período, Uberlândia, 2002.

Com base nestes resultados, verificamos que os períodos apontados, no sentido de maior contribuição, para a formação do estudante de odontologia foram: os sétimo e oitavo períodos, que se caracterizam pelas ações de intervenção bucal, ou seja, atenção clínica restauradora, junto às crianças triadas pelos estudantes de odontologia, na escola de primeiro grau, conforme a classificação de risco individual de cárie e doença periodontal. Estas ações são desenvolvidas, predominantemente, na clínica odontológica, do Centro Universitário, e obteve opinião unânime dos 
estudantes de odontologia de maior contribuição para sua formação.A segunda maior contribuição foi a do $3^{\circ}$ período, onde o estudante de odontologia responsabilizourse e vinculou-se, de forma direta, com a saúde bucal das crianças da escola, executando um programa de higienização, fluorterapia e educação em saúde, conforme o risco.

Os períodos apontados, em seguida, com maior contribuição para a formação do estudante universitário odontológico, perfazendo $95 \%$ e $88 \%$ de respostas positivas temos os segundo e o quinto período, respectivamente. O segundo período caracteriza-se como o primeiro contato do estudante com uma realidade de uma comunidade socialmente excluída, realizando as primeiras etapas preconizadas pelo PSF, do Ministério da Saúde, voltadas para o cadastramento e visitas domiciliares, levantamento epidemiológico, diagnóstico situacional e elaboração de um Plano de Ação.

Consideraram que o quarto período possibilitou contribuição com sua formação, em $78 \%$ das respostas. Em contraponto, constitui-se na etapa do Projeto com maior índice de críticas e rejeições, através de $22 \%$ das respostas obtidas, merecendo atenção da equipe de docentes responsáveis pelo Projeto, sobre a fundamentação das critícas apresentadas.

Assim, alguns aspectos criticados pelos estudantes merecem uma reflexão mais aprofundada do seu significado, como por exemplo, a eliminação das visitas domiciliares, o desinteresse das famílias pela atenção preventiva e as atividades desenvolvidas não resultarem em "ações práticas." Faz-se necessário contextualizarmos que o Projeto estudado está em construção, consolidando-se, tanto científica quanto, socialmente, representado um "modelo em tensão", frente a um modelo odontológico hegemônico e tradicional, socialmente reconhecido e que se 
constitui, inclusive, na referência destes alunos para a escolha do curso de odontologia.

Por outro lado, a última critica sugere ampliação de procedimentos odontológicos específicos, ou seja, leva-nos a crer, que há a necessidade deste grupo de docentes desenvolver o uso de tecnologia apropriada, junto à família, viabilizando, por exemplo, o uso de equipamento odontológico portátil, de fácil translado, para atuação em lesões da doença cárie (cavitações no esmalte e dentina), permitindo a execução de alguns procedimentos odontológicos mais simples no domicílio, como as técnicas de restaurações atraumáticas, selantes invasivos, dentre outras, constituindo-se em apontamentos dignos de ajustes ao Projeto. Representa potencializar novos espaços de atuação da odontologia, que devem ser implementados, para maior resolutividade das ações da equipe odontológica em nível de atenção primária.

Verificamos, também, que alguns relatos pertinentes apontando fragilidades operacionais do Projeto, merecendo destaque os horários desencontrados entre estudantes e famílias a serem visitadas, limitações das ações no domicílio e repetição de ações.

Por outro lado, é importante considerar neste processo o perfil do estudante de odontologia, onde nos deparamos com um aluno de poder aquisitivo diferenciando, pertencente à classe média alta, que não necessita inclusive trabalhar para contribuir com a renda familiar.

A integração e sensibilização com a situação das comunidades socialmente excluídas, verificando de forma mais próxima as condições de saneamento, moradia, cultura, informação, saúde, enfim de toda uma gama de realidades, corresponderam 
às contribuições encontradas, comuns aos vários relatos dos estudantes de odontologia. Contudo, articular os aspectos inerentes às condições de vida destas comunidades, com a determinação social do processo saúde e doença, não mereceu o pronunciamento e reconhecimento do estudante na mesma magnitude que ocorreu com a sensibilização frente às condições de vida identificadas.

Assim, podemos afirmar que este Projeto constituiu-se nos primeiros contatos efetivos do estudante de odontologia, com aspectos da saúde pública e a sociologia. Como visto anteriormente, repete-se, no registro dos estudantes, o caráter pioneiro do Projeto, proporcionando os primeiros contatos práticos, construindo as primeiras noções e desenvolvendo atividades relacionadas à odontologia, junto às crianças de diferentes realidades, no conjunto da sociedade, associando, durante todas as fases do Projeto, a teoria com a prática.

Por outro lado, a identificação, pelo estudante de odontologia, de que saúde bucal não é uma prioridade para as famílias visitadas, é sob nossa perspectiva, contribuição importante, das atividades de ensino do Projeto, proporcionando ao estudante a reflexão sobre uma das questões fundamentais da saúde coletiva: os valores que sustentam hábitos de higiene, cuidados adequados com o corpo e o ambiente são determinados pelas diferentes condições de vida e cultura familiar.

Portanto, o desafio de despertar as famílias sobre os benefícios destes cuidados, envolve aspectos que vão além da educação e orientação para saúde, necessitando de uma dinâmica diferenciada de atenção à saúde, articulada com as mudanças macroestruturais necessárias, principalmente desarmar os mecanismos que concentram renda no Brasil e ampliar a disponibilidade de empregos. 
Visto por outro ângulo, as visitas domiciliares podem representar, em algumas situações, invasão da privacidade familiar, sendo que os anseios da família visitada não necessariamente coincidam com as informações que o estudante têm como um grande valor a oferecer.

Participar de atividades de ensino continuadas e seqüenciais durante todos os anos do Curso foi considerado como outra contribuição do Projeto, fornecendo retorno às famílias e possibilitando encaminhamentos diversos para resolução dos problemas encontrados. Salientaram que o Projeto possibilitou o diagnóstico de diferentes casos odontológicos, apreendidos nas aulas teóricas, inclusive de outras disciplinas.

O desenvolvimento de ações preventivas junto às crianças, na faixa etária de zero a seis anos de idade, proporcionou a aprendizagem no lidar com crianças menores, na maioria dos casos, desprovidas de cuidados e de afeição e economicamente desfavorecidas, fizeram com que o estudante desenvolvesse, além da sensibilização às questões de cunho social, a necessidade de adotar posturas mais tolerantes e diferenciadas no atendimento à criança.

Mais de uma vez, o estudante mencionou que as atividades de ensino, proporcionadas pelo Projeto, permitiram associações com aspectos apreendidos em outras disciplinas.

A necessidade de utilização de técnicas de reforço cotidiano, com as crianças para a criação ou mudança de hábitos de higiene foi demarcado, também, como aprendizagem a partir do contato prático, viabilizado pelo Projeto.

A unanimidade na contribuição proporcionada pelo Projeto, durante o ciclo clínico, predominando as ações clínicas e restauradoras, durante o $4^{\circ}$ ano de 
odontologia, evidencia uma vertente positiva, mas, também, sob a ótica de cautela, demonstra uma vertente preocupante.

A vertente positiva refere à articulação do estudante sobre o "todo" do Projeto, colocando em prática o que foi planejado, concluindo um ciclo de atenção preventiva, com a clínica restauradora, quando necessária. Possibilitou intervenções clínicas restauradoras integradas, sob a perspectiva da saúde coletiva, aprendendo a lidar com o atendimento à criança de forma criativa e ágil, adequando o uso de técnicas e procedimentos, lidando com diferentes casos odontológicos, concretizando, enfim, a praxe iniciada nos primeiros períodos do curso de odontologia.

Enfim, atuar sob a perspectiva do paradigma da promoção em saúde de controle e redução da atividade cariosa, onde em caso de dúvida - "previna, aguarde e avalie" desconsiderando o paradigma cirúrgico restaurador, onde o esmalte defeituoso de hoje será uma cavidade amanhã, sendo que em caso de dúvida "restaure."

Por outro lado, a vertente negativa é representada pelo forte atrativo da prática clínica, da intervenção curativa, do viés de um modelo centrado, apenas na cura da doença, ainda entendido pelo estudante como o que há de mais importante, que inclusive fornece sua identidade, enquanto profissional, referendando o modelo familiar e vigente no mercado de trabalho, que o influenciou para a escolha da profissão. A partir dos relatos apresentados, na contribuição desta etapa, observa-se que as expressões: "colocar em prática", "dar o tratamento", "o contato direto com o paciente e a boca.", "atendimento específico", "tratamento propriamente dito" e demais expressões utilizadas, pelos estudantes, demonstraram a percepção de que o 
papel do odontólogo "de verdade", ou seja, reconhecido e aprovado socialmente é o do odontólogo interventor, utilizando de toda a tecnologia a que tem direito.

Assim, mesmo o Projeto buscando demonstrar o avanço da epidemiologia e da cariologia, novas tendências no agir do processo saúde e doenças bucais, definindo um programa de prevenção que se propõe à redimensionar o modelo odontológico supracitado, não seduz o estudante como o faz a atenção clínica curativa.

Nossa perspectiva fundamenta-se na seguinte base teórica: deve preceder a atenção curativa, a inclusão da comunidade em um programa de orientação, higienização e fluorterapia, diminuindo as necessidades odontológicas acumuladas, referenciando para a clínica apenas parte desta comunidade, que realmente necessita de intervenção clínica restauradora.

Infelizmente, podemos observar pelos resultados obtidos, que as ações de promoção, prevenção, planejamento da ação e resgate de cidadania, são ainda encaradas como "ação menor", e até desprezadas perto das ações curativas, por um grupo significativo de estudantes.

Além disso, vale ressaltar que o espaço da clínica representa, pelas suas características extremamente sofisticadas, possuindo equipamentos de última geração e espaço físico privilegiado, incomparável, em termos de estímulo para aproximação do aluno, quando tentamos motivá-lo a utilizar outros espaços para levar a saúde bucal à comunidade, promovendo o resgate social da profissão, como, por exemplo, o domicílio das famílias e diferentes equipamentos sociais. Assim, este modelo em construção não oferece o conforto e proteção típica do habitat considerado natural e idealizado pelo estudante universitário de odontologia e reforçado pelo modelo 
odontológico vigente - a odontologia de mercado, sob influência político ideológica do projeto de sociedade neoliberal, conforme afirma Narvai (1994).

Nas limitações creditadas ao Projeto, notadas pelos estudantes evidencia-se a procura constante dos estudantes em proporcionar respostas ditas "efetivas" às famílias que, também, reflete as questões contempladas no parágrafo anterior.

Finalizando, quanto às contribuições do Projeto na formação do aluno, observa-se um amplo saldo positivo, com algumas limitações concernentes as necessidades de reajustes e reflexão quanto à influência do modelo odontológico tradicional. Contudo, não cabem dúvidas a respeito de prosseguir e aprimorar este Projeto, nas transformações curriculares que objetivam a formação de cirurgiõesdentistas aos requerimentos do SUS e às necessidades da maioria da população.

\title{
1.13.3 Sobre o desejo, do estudante de odontologia, em atuar
}

\section{profissionalmente na área de abordagens coletivas em saúde bucal}

\author{
"Porque acha hoje, uma das áreas da odontologia \\ mais importantes para a comunidade, foi quando \\ aprendeu a lidar com o todo, ficando fácil lidar com o \\ individual." (Estudante de odontologia 7). \\ "Porque eu acho que tenho um dever, um \\ compromisso com a sociedade..." (Estudante de \\ odontologia 8).
}

Com base nos dados obtidos, sobre o desejo do estudante de odontologia atuar, após se graduar, em abordagens coletivas em saúde bucal, observamos que dos 51 estudantes, 21 afirmaram que sim (41\%), 13 responderam que não (25\%), 10 responderam que talvez (20\%) e sete apresentaram outras alternativas (14\%), conforme demonstrado na Figura 7. 


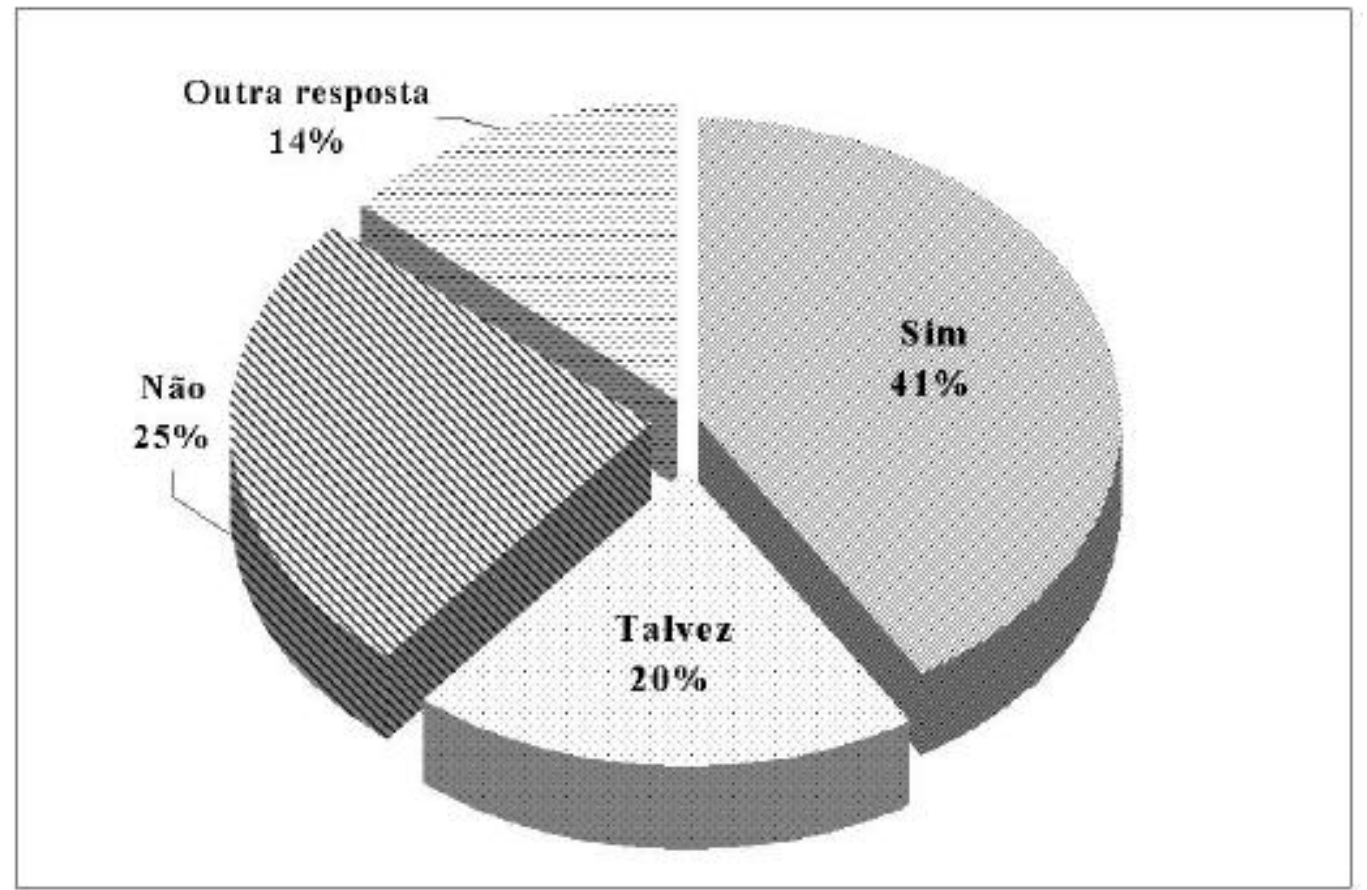

Figura 7 - Respostas dos estudantes do curso de odontologia, segundo suas pretensões em atuar profissionalmente em abordagens de alcance coletivo em saúde bucal. Uberlândia, 2002.

Analisando as justificativas dos $41 \%$ dos estudantes de odontologia que afirmaram pretender atuar em abordagens coletivas, observamos que os motivos mais comuns são: consciência da necessidade de garantia do direito à saúde da população; a possibilidade de contribuição social e de atuação resolvendo os problemas das pessoas, juntamente, com a exposição de um caráter assistencialista e equivocado de “ajuda aos mais carentes e inferiores." Aparece, também como justificativa relevante, a possibilidade de remuneração fixa garantida (salário), viabilizando o início da carreira profissional.

As justificativas com menores porcentagens foram: a possibilidade de visão mais ampla, de desenvolvimento humano, aprendizado de convivência com outras pessoas e com as necessidades da população e de trabalho não limitado ao atendimento de consultório particular. Apareceram, também, outras justificativas 
como facilidade em conseguir oportunidade para atuar em sua cidade de origem e identificação com a área de saúde pública, conforme demonstrado na Tabela 18.

Tabela 18 - Justificativas dos estudantes de odontologia, segundo a opção em atuar em abordagens coletivas em saúde bucal, segundo ordem decrescente de freqüência. Uberlândia/ 2002

\begin{tabular}{|c|c|c|c|}
\hline GRUPO & CATEgORIAS & FREQÜÊNCIA & $\%$ \\
\hline $1^{\mathrm{o}}$ & $\begin{array}{l}\text { Garantir o direito à saúde/compromisso com a sociedade/ } \\
\text { possibilidade de resolver os problemas odontológicos das } \\
\text { pessoas/área importante para resolver os problemas da } \\
\text { comunidade/atuar na área de saúde pública/acredita na proposta } \\
\text { do PSF/contribuição social/ melhorar a qualidade de vida das } \\
\text { pessoas. }\end{array}$ & 8 & 36 \\
\hline $2^{\circ}$ & $\begin{array}{l}\text { Caráter assistencialista (ajudar os mais carentes/ inferiores)/ é } \\
\text { gratificante, pois há valorização do serviço/ ajudar pessoas que } \\
\text { não tem acesso ao atendimento privado. }\end{array}$ & 4 & 18 \\
\hline $3^{\circ}$ & $\begin{array}{l}\text { Possibilita remuneração fixa garantida (salário) viabilizando o } \\
\text { inicio de carreira. }\end{array}$ & 3 & 13 \\
\hline $4^{\mathrm{o}}$ & $\begin{array}{l}\text { Possibilita visão mais ampla/ desenvolvimento humano/ aprende } \\
\text { a conviver com outras pessoas e as necessidades da população/ } \\
\text { trabalho não limitado ao atendimento de consultório particular. }\end{array}$ & 2 & 9 \\
\hline $5^{\circ}$ & $\begin{array}{l}\text { Facilidade em conseguir esta oportunidade na cidade do } \\
\text { estudante de odontologia/ já possui emprego garantido em uma } \\
\text { cidade do interior, no PSF. }\end{array}$ & 2 & 9 \\
\hline $6^{\circ}$ & Oportunidade em desenvolver todas as áreas da odontologia. & 1 & 5 \\
\hline $7^{\circ}$ & $\begin{array}{l}\text { Pretende atuar em cidade do interior, onde predomina este tipo } \\
\text { de serviço. }\end{array}$ & 1 & 5 \\
\hline $8^{\circ}$ & $\begin{array}{l}\text { Identifica-se com a área de saúde pública e em fornecer } \\
\text { orientações. }\end{array}$ & 1 & 5 \\
\hline & Total* & 22 & 100 \\
\hline
\end{tabular}

Analisando as justificativas dos $25 \%$ dos estudantes de odontologia, que corresponde a 13 alunos que não pretendem atuar em abordagens coletivas em saúde bucal, observamos que os motivos mais comuns foram: não identificação com a área, demonstrando preferência e interesse por especialidades, principalmente a cirurgia buco-maxilo-facial é apontada com maior freqüência; considerarem o atendimento em abordagens coletivas em saúde bucal, improvisado e muito superficial; 
identificação e preferência pelo trabalho em consultório, individual e não voltado para uma comunidade; preferência por "clinicar" e o fato de já possuir ocupação garantida com o pai odontólogo ou ter adquirido seu consultório próprio.

Obtivemos dez estudantes de odontologia que posicionaram - se, sem definição (20\%), sobre onde desejam atuar, respondendo "talvez", para a possibilidade de atuação em abordagens coletivas, em saúde bucal, apresentam como justificativas: associação com trabalhos assistencialistas e voluntários; identificação com o caráter generalista deste tipo de atuação; sujeição às opções do mercado de trabalho e às precárias condições salariais e de trabalho oferecida nesta área e a influência e determinação política para este tipo de atuação.

Obtivemos, ainda, que $14 \%$ dos estudantes de odontologia apresentaram "outra resposta" à indagação sobre o desejo de atuação em abordagens coletivas em saúde bucal, representadas pelas justificativas fundamentadas nos seguintes aspectos: necessidade do retorno financeiro, que o consultório particular pode lhe oferecer; pretensão em restringir o caráter assistencialista e voluntário, deste tipo de atuação, dentro de sua especialidade, em seu consultório privado; desejo de associar atendimento no setor privado, juntamente com área pública - postos de saúde; não identificação com este tipo de trabalho, mas, caso seja necessário irá "se sujeitar" a esta área de atuação e situações de indefinição sobre a área que pretende atuar.

Vale ressaltar uma observação de um estudante que considera que não se trata de um "desejo" de onde o dentista iria atuar, mas sim de quais opções ele terá junto ao mercado de trabalho.

Aflorou nas respostas do estudante de odontologia a compreensão equivocada e de caráter assistencialista sobre o espaço de atuação da saúde bucal coletiva. 
Verificamos a ausência de pronuncia mento sobre a praticidade social da odontologia, demarcando visão alienada, assistencialista e idealizada do modelo odontológico empresarial. Além disto, esta visão elitista reforça a idéia de que a atividade de saúde coletiva é para pobres, de baixa qualidade, limitando-se a uma "ação pobre para gente pobre", comprometendo a possibilidade de uma ação transformadora e mais radical das ações de saúde coletiva.

\title{
1.13.4 Sobre as especialidades odontológicas que o estudante de odontologia pretende atuar
}

\author{
"Vou fazer cirurgia, porque me identifico, \\ interesso e gosto mais... É feito uma ou duas \\ intervenções e pronto."(Estudante de \\ odontologia 8).
}

A partir dos resultados obtidos, observamos que $83 \%$ dos estudantes, que estão cursando o quarto ano da graduação em Odontologia, definiram a especialidade em que desejará atuar profissionalmente. Apenas $21 \%$ apresentam-se com indefinição sobre que área seguir, sendo que $4 \%$ dividem-se entre as áreas de docência em saúde coletiva e periodontia/implante e $2 \%$ entendem que esta decisão depende da região onde irá atuar, conforme apresentado na Tabela 19.

Tabela 19 - Especialidades Odontológicas, segundo a preferência para atuação profissional do estudante de odontologia. Uberlândia, 2002

\begin{tabular}{lcc}
\hline \hline \multicolumn{1}{c}{ ESPECIALIDADE } & FREQÜÊNCIA & $\%$ \\
\hline Cirurgia e traumatologia Buco-Maxilo-Facial & 11 & 21 \\
Sem definição & 8 & 15 \\
Odontopediatria & 7 & 13 \\
Ortodontia & 6 & 11
\end{tabular}


(conclusão)

\begin{tabular}{lcc}
\hline \hline \multicolumn{1}{c}{ ESPECIALIDADE } & FREQÜÊNCIA & $\%$ \\
\hline Dentística Restauradora & 4 & 7 \\
Endodontia & 4 & 7 \\
Saúde Coletiva & 3 & 6 \\
Clínica Geral & 2 & 4 \\
Docência/ Área Coletiva & 1 & 2 \\
Periodontia/ Implante & 1 & 2 \\
Depende da região onde irá trabalhar & 1 & 2 \\
\hline Total* & 53 & 100 \\
\hline \hline
\end{tabular}

* - não corresponde ao número de estudantes, mas sim ao número de vezes que a especialidade foi apontada.

Verificamos oito especialidades, dentre as onze existentes, que definem as preferências de atuação do estudante de odontologia, após sua graduação, em ordem decrescente de aparecimento: Cirurgia e traumatologia Buco-Maxilo-Facial, Odontopediatria, Ortodontia, Periodontia, Dentística Restauradora, Endodontia, Saúde Coletiva (Odontologia Preventiva e Social) e Clínica Geral.

Os motivos mais freqüentes para a escolha da área de atuação, segundo os estudantes de odontologia são: a identificação, interesse e afinidade pela área, maior habilidade e o fato de apresentar resultados imediatos. Enquanto as justificativas dos estudantes que não definiram área para atuação são: identificar-se com várias áreas/disciplinas e o desejo de desenvolver um trabalho mais integrado.

Chama a atenção, algumas colocações diferenciadas para a escolha de cada uma das especialidades odontológicas, conforme relacionamos, em seguida:

Cirurgia e traumatologia Buco-Maxilo-Facial: realização de poucas intervenções por período de trabalho, fascínio e sensação de realização; 
Odontopediatria: facilidade e paciência ao lidar com crianças, influência e afinidade pelas atividades desenvolvidas no Projeto de Saúde Bucal Coletiva e proporcionar o crescimento da criança com consciência em saúde bucal; Ortodontia: atuação junto ao pai, sonho antigo e disciplina que mais chamou a atenção; Periodontia: escolheria esta área, caso tenha que atuar no consultório (pois tem mais afinidade pela saúde coletiva), inclinação e afinidade pelos procedimentos cirúrgicos e importância da gengiva; Dentística Restauradora: não se identifica com procedimentos que tenha que lidar com sangramentos (ex: área cirúrgica) e já desenvolve a monitoria; Docência: não deseja atuar em consultório; Clínica Geral: facilidade na abordagem mais geral.

A tendência à especialização precoce na área de odontologia é comprovada pelo fato de $85 \%$ dos estudantes, cursando o quarto ano, já terem definido a especialidade em que irão atuar, após se graduarem. A saúde coletiva ou a odontologia social e preventiva é vista como uma área de pouco retorno financeiro, um sacerdócio e confundida com ações de cunho assistencialista, apresentado baixo índice de escolha do estudante.

A escolha da especialidade recai sobre os motivos comumente apontados de identificação, e afinidade com a disciplina, habilidade e o fato de proporcionar resultados imediatos.

Concordamos com Teixeira (1995, p. 187) que se por um lado a atividade especializada aumenta o domínio e a competência num determinado campo de atuação, promovendo melhor qualidade nos serviços oferecidos à sociedade, por outro, esse intenso processo leva, cada vez mais, a fragmentação do conhecimento e do processo de trabalho em que o profissional está inserido. 
A tendência a especialização dentro do contexto vivido pelo país onde a situação de falta e pletora de dentistas no Brasil ocorrem simultaneamente, devido a concentração destes em regiões mais prósperas, é bem assinalado por Werner (1989, p. 34), complementado que:

"As faculdades de odontologia sob controle governamental gastam os poucos recursos disponíveis, que poderiam ser despendidos em pesquisa ou atendimento ao público, para o treinamento de profissionais altamente especializados que correm um risco cada vez. maior de se tornarem subempregados ou desempregados."

Em nossa opinião este é um problema vivido também pela Instituição de Ensino privado, que no exemplo específico deste Projeto, tem procurado saídas, em busca de um novo mercado profissional para odontologia, que começa a se desenhar através da inserção da odontologia no Programa de Saúde da Família. Ainda, de forma tênue e pontual, não integrada com as demais disciplinas, mas com certeza apresentando uma proposta de promoção de medidas preventivas para preservação da saúde bucal associado à organização dos serviços de clínica, para melhorar o acesso da população aos serviços odontológicos.

Concordamos com Werner (1989?) que deveria ser mais enfatizada a formação de pessoal auxiliar na substituição de cirurgiões dentistas superqualificados.

\subsubsection{Sobre os aspectos considerados mais importantes, dentre as} atividades de ensino desenvolvidas durante o Projeto Saúde Bucal

\section{Coletiva}

"O mais importante foi cadastrar as crianças e adultos e eles receberem tratamento." (Estudante de odontologia 9). 
Tendo em vista agrupar as atividades de ensino mais importantes apontadas pelos estudantes de odontologia, durante o Projeto Saúde Bucal Coletiva, foi possível definirmos oito categorias. Dentre elas, quatro atividades de ensino são consideradas mais relevantes, conforme demonstrado na Tabela 20 .

Tabela 20 - Atividades de Ensino desenvolvidas pelo Projeto Saúde Bucal Coletiva, segundo sua importância, UNIT, Uberlândia, 2002

\section{ATIVIDADES DE ENSINO \\ FREQÜÊNCIA \\ $\%$}

1. Visita domiciliar, cadastramento, orientação, educação em saúde, diálogo com as famílias, prevenção, primeiros contatos com pacientes, encaminhamento e atendimento desenvolvido, junto à comunidade, nos bairros.

2. Realizar ações efetivas de prevenção, enfocando as crianças nas escolas.

3. Inserção do estudante em uma realidade política/sócio/cultural estranha à sua vivência cotidiana, evidenciada em distorções nas condições de vida e saúde, através dos diferentes valores encontrados.

$10 \quad 17$

4. Aulas práticas no Ciclo Clínico.

5. Associação entre as ações técnicas, aspectos sociais e intervenção do Estado.

$3 \quad 5$

6. Compreender o funcionamento do Sistema Único de Saúde.

7. Todas as atividades foram relevantes.

12

8. Não respondeu.

$$
\text { Total* }
$$

57

* - não corresponde ao número de estudantes, mas sim a número de vezes que a atividade e ensino foi apontada.

Analisando as oito categorias, onde agrupamos os aspectos mais importantes, dentre as atividades de ensino do Projeto, apresentamos as respostas comuns que expressam a visão do aluno, em cada uma das categorias consideradas.

Assim, observamos que a primeira categoria obteve $30 \%$ da preferência dos estudantes de odontologia, representada por algumas respostas comuns: "o mais importante foi cadastrar as crianças e adultos e eles receberem tratamento"; “... levar um atendimento à população que talvez não teria acesso normalmente"; "ir aos 
bairros, cadastrar as pessoas, porque lá você tem contato com a realidade delas"; "ir aos domicílios porque lá havia a possibilidade de ampliar a informação...”; “... estarmos trabalhando com as famílias, através do diálogo e de ações preventivas e curativas com resultados bons...”; “... atendimentos domiciliares, conquistar a confiança e participação das famílias"; “atender pessoas mais carentes, contribuiu com o conhecimento"; "ir aos bairros e encaminhar as pessoas para atendimento, quando necessário"; "levar informações até a população que não tem esclarecimentos"; "atendimento de crianças de bairros... são mais carentes“.

Em seguida, com 26\% das opiniões dos estudantes, encontra-se a segunda categoria representada pelas seguintes respostas mais comuns: "a prevenção, porque pessoas de classe mais carentes não têm informação... e quando você realiza este trabalho pode melhorar muito a saúde bucal destas pessoas"; "o trabalho nas escolas porque está trabalhando com crianças, evita muita doença”; “...ir a escola, passar informação para as crianças, elas levavam para casa e para os colegas"; "unir saúde e educação nas escolas realizando escovação supervisionada e o uso lógico do flúor"; "a prevenção porque é a partir dela que você evita maiores problemas"; "poder conscientizar o paciente da importância da saúde bucal e poder contribuir em um sorriso mais alegre da população"; "a prevenção porque você tem ótimos resultados"; "o tratamento preventivo das crianças conforme sua classificação de risco".

A terceira categoria, incluindo $17 \%$ das opiniões dos estudantes, considera os seguintes aspectos de ensino mais importantes: "o contato com outra realidade, a vida das pessoas atendidas é totalmente diferente da nossa"; "o contato com crianças e outras pessoas de classes sociais menos privilegiadas... ampliou o trabalho da 
faculdade"; "o contato com a população de baixa renda ampliou o conhecimento acerca da realidade social, muito diferente dos alunos da UNIT"; "o relacionamento com a população"; "contato com crianças e pessoas com condições mais baixas de vida, com um grau de instrução menor sobre saúde bucal"; "contato com a pessoa carente fora do consultório"; "desenvolver a solidariedade"; "aprender a lidar com pessoas de nível social diferente e a dar mais valor na educação recebida pelos pais".

A quarta categoria, com $16 \%$ das opiniões dos estudantes, considera os seguintes aspectos de ensino mais importantes: “... na clínica você pode ajudar a resolver o problema deste pessoal..."; “a clínica é muito importante.”; “a prática na clínica porque você aprende de tudo um pouco, ficando mais preparado. na clínica você está tratando.”; “... início da intervenção odontológica mais prática (direta)”; “a clínica porque você tem um contato mais profissional.”; “...trouxe a criança e fizemos o trabalho completo.”; “... possibilitou aprendizado conjunto”; “ ... aprendemos jogo de cintura, para atender um paciente que muitas vezes não quer colaborar."

A quinta categoria, por sua vez, com apenas 5\% das opiniões dos estudantes, considera os seguintes aspectos de ensino mais importantes: "prevenção em escolas”; “... estabilizar os que estão com problemas (na clínica) e depois trabalhar com a prevenção nas escolas e famílias - conscientização”; “os mecanismos de controle das doenças e a socialização da população”; “... noção de que o estado não cumpre com a demanda”; “... não existe educação em saúde”; “... muita coisa precisa ser feito para mudar este quadro”; “... promoção e manutenção da saúde”. 
As três últimas categorias consideradas, conforme se observa na Tabela 20, corresponderam à apenas três manifestações, perfazendo $6 \%$ das opiniões dos estudantes, não sendo representativo dentro do universo pesquisado.

Sintetizando, observamos que várias são as atividades de ensino consideradas mais importantes, merecendo destaque do estudante: a aplicação de diversas ações, dentre elas, a visita domiciliar, cadastramento, diálogo com as famílias, orientações, encaminhamentos, e demais atividades desenvolvidas junto à comunidade, nos bairros; realização de ações efetivas de prevenção, enfocando as crianças nas escolas; a inserção do estudante em uma realidade política/sócio/cultural estranha à sua vivência cotidiana e as aulas práticas no ciclo clínico do quarto ano de odontologia.

Em pesquisa intitulada: "Contribuição de diferentes atividades para o processo de aprendizagem, na percepção de alunos de medicina", da Faculdade de Medicina de Ribeirão Preto da Universidade de São Paulo, foi realizado um levantamento entre os estudantes do primeiro ao quarto ano, através de questionário padronizado. A análise de resultados permitiu verificar no que diz respeito a estratégia "Aula Prática no Ciclo Básico" a percepção de sua importância diminui à medida que o aluno avança no curso e a grande modificação nesse perfil ocorre na passagem do segundo para o terceiro ano. A estratégia de ensino "Aula Prática no Ciclo Clínico" foi considerada maciçamente, como de grande importância. (FIGUEIREDO et al., 1996). Observamos parcial similaridade com nossos resultados, na medida em que o nosso ciclo clínico tem aprovação unânime, diferente das aulas práticas no ciclo básico, que apesar de reconhecida sua importância, se situa em patamar inferior de relevância, quando comparada com o ciclo clínico. 


\subsubsection{Sobre as atividades de ensino, do Projeto Saúde Bucal Coletiva, que deveriam ser eliminadas ou alteradas}

"Ficou a sensação de uma promessa não cumprida." (Estudante de odontologia 10).

Frente à possibilidade de eliminar ou modificar as atividades de ensino propostas pelo Projeto, obtivemos 24 opiniões, que consideraram que nenhuma atividade de ensino deveria ser eliminada ou modificada, perfazendo $38 \%$ das respostas; 22 sugestões para alterações (35\%) e 17 sugestões de eliminação (27\%).

Os estudantes de odontologia consideram, em 38\% das respostas, que não há necessidade de alterações nas atividades de ensino, tendo como justificativas para manter o Projeto como está os seguintes aspectos considerados mais relevantes: as atividades de ensino e a metodologia de aplicação do Projeto foram positivas, válidas e proporcionaram conhecimentos, resultados e progresso; o Projeto foi bem elaborado, suas etapas são complementares, tiveram sua contribuição, enfatizaram a lógica das causas dos problemas de saúde e cumprem com a função de levar benefícios às pessoas do bairro e às crianças da escola e aproxima o estudante da realidade; promove a utilização dos recursos disponíveis e alternativos; e constitui-se em atividades simples, que contribuem para o crescimento profissional, sendo que ao final do quarto ano do curso de odontologia é possível compreender a lógica das etapas do Projeto. Cinco alunos consideraram que nenhuma atividade do Projeto deva ser alterada, contudo não justificaram suas opiniões.

Com base nos resultados obtidos, verificou-se que as principais atividades que são dignas de modificação foram: as visitas domiciliares, ampliar contato com pais nas atividades desenvolvidas na escola, fundir conteúdos da disciplina 
denominada Odontologia Coletiva 1 e 1l, em uma única disciplina; vincular a parte preventiva com a curativa; alterar a quantidade de pacientes atendidos, limitando a um número menor de pacientes com maiores necessidades, abrir espaço para outras instituições participarem do Projeto e ampliar as atividades práticas na escola, considerando que algumas das crianças classificadas em baixo risco ficaram sem atendimento.

Para os dois problemas enfrentados, pelos estudantes de odontologia, sobre algumas famílias não demonstrarem interesse nas informações prestadas e os horários preconizados para as visitas coincidirem com o horário em que as famílias estavam para o trabalho ou dormindo, tendo como exemplo a expressão: “... tirávamos as pessoas da cama.”Sugeriram as seguintes alternativas: “... é necessário mudanças no horário das visitas, para não atrapalhar as pessoas”, a realização de triagens prévias, para atender os interessados e não precisar realizar busca ativa "bater na porta" e eleger um local no bairro para que as famílias interessadas procurarem uma unidade de saúde pré-estabelecida.

Sugerem, também, voltar ao primeiro contato com as famílias, porque com o conhecimento adquirido poderiam agora fazer algo por elas, expressas na frase: “ficou a sensação de uma promessa não cumprida." Quanto às atividades na creche os estudantes propõem intervenções com as mães, substituindo as atividades com as crianças.

Houve $27 \%$ de sugestões para que algumas das atividades de ensino fossem eliminadas. As atividades que mereceram destaque nesta categoria foram as visitas domiciliares no segundo ano do curso (quarto período) e como menos relevantes eliminar o trabalho nas creches. 
Ao sugerirem a eliminação das visitas domiciliares, aparecem como justificativas mais freqüentes: a repetição das visitas domiciliares no quarto ano, pois já foram realizadas no primeiro ano, tornando-se cansativas e aborrecidas; refere-se, também, às situações em que os estudantes não foram bem recebidos - recusa de atendimento e falta de compromisso com os estudantes por parte das famílias; os perigos representados por alguns locais de visitas domiciliares, para a segurança do estudante; ausência de recursos para prevenção apropriados para utilização nas visitas, como, por exemplo, "escovódromo", modelos de arcadas dentárias e ausência de condução fornecida pela universidade para translado no bairro; necessidade de uma proposta mais específica de atuação para atendimento das famílias visitadas e tempo considerado improdutivo.

Quanto à eliminação da etapa na creche, os motivos selecionados são: não houve acréscimo de conhecimentos para o estudante e não houve benefício para as crianças, pois as mesmas não conseguem assimilar o conhecimento repassado, considerando que fazem parte da faixa etária de menores de seis anos de idade.

Observamos que as visitas domiciliares apesar de promoverem uma "sacudidela" nos estudantes, pois os colocam em confronto com o contraste e a busca de um modelo de consultório odontológico idealizado, faz com que alguns estudantes procurem eliminar ou modificar esta atividade de ensino.

\subsubsection{Sobre as expectativas frente às atividades de ensino do Projeto}

\section{Saúde Bucal Coletiva}

“Não sabia nem que existia." (Estudante de odontologia 11). 
“... acha que esta é a inovação e a mudança de visão da odontologia.” (Estudante de odontologia 12).

Para melhor compreensão das respostas às expectativas dos estudantes, frente às atividades de ensino do Projeto, as mesmas foram agrupadas em quatro categorias a partir da existência ou ausência de expectativa e de possuir conhecimento prévio do Projeto. Assim, 41\% dos estudantes não apresentavam expectativas, 33\% especificaram algum tipo de expectativa, $18 \%$ esperavam as atividades que aconteceram e $4 \%$ já conheciam, previamente, as atividades do Projeto, conforme demonstrado na Tabela 21.

Tabela 21 - Expectativas do estudante de odontologia frente ao Projeto Saúde Bucal Coletiva. Uberlândia, 2002

\begin{tabular}{lcc}
\hline \hline EXPECTATIVAS FRENTE AO PROJETO SAÚDE BUCAL COLETIVA & FREQÜÊNCIA & \% \\
\hline Não apresentava expectativa & 21 & 41 \\
$\begin{array}{l}\text { Apresentava expectativa sobre as atividades à serem } \\
\text { desenvolvidas }\end{array}$ & 17 & 33 \\
$\begin{array}{l}\text { O Projeto correspondia à expectativa do estudante } \\
\text { O estudante conhecia previamente as atividades do Projeto }\end{array}$ & 9 & 4 \\
Não responderam & 2 & 4 \\
\hline Total & 51 & 100 \\
\hline \hline
\end{tabular}

Com base nos resultados obtidos, verificourse que as justificativas levantadas pelos estudantes de odontologia, sem expectativas foram: reconheciam como atividades de ensino do curso de odontologia apenas o espaço da universidade, a decisão por cursar odontologia foi intempestiva: “... de ultima hora" e o desconhecimento e desinformação sobre o Projeto e o Curso de Odontologia: “... 
nunca ter ouvido falar”; “... não tinha esta visão”; “... não sabia nem que existia”; “... não fazia nem idéia.”

Algumas manifestações positivas sobre o Projeto, sob a ótica dos estudantes de odontologia, que não possuíam nenhuma expectativa, foram expressas como: “achou muito válido, principalmente a prática e pela vivência”; “... não tinha expectativas que houvesse tanto retorno"; "acha que é um trabalho importante porque permitiu levar o serviço odontológico a quem não tinha acesso a ele"; "não esperava, depois gostou e achou interessante”; “... hoje pensa que o projeto deveria fazer parte do currículo desde o início, porque é estimulante para o aluno”; “... não tinha idéia que era dessa forma de dedicação, de vários períodos e com continuidade"; "acha importante a interação do aluno com a comunidade para seu amadurecimento como pessoa e crescimento profissional”; “... foi uma experiência que não dá para comparar"; "não sabe se existe em outros cursos"; "a forma como é passada acrescenta ao currículo"; "não sabia que a faculdade tinha esse tipo de programa"; “... acha que esta é a inovação e a mudança de visão da odontologia”; “... tudo foi novidade".

Quanto aos estudantes que manifestaram alguma expectativa frente ao Projeto, observamos que as atividades de ensino mais salientadas foram: noções de prevenção, executar trabalhos de campo, conhecer os diferentes aspectos sociais e bucais, caráter assistencialista: “... ajudar pessoas carentes.” ; “... atender pessoas que não tem como pagar o particular”; “... achei que era uma matéria voltada para o povão"; “... atender pessoas carentes igual ao PSF que aparecia na TV”; caráter de humanização da profissão, atividades superficiais e não resolutivas, atividades de 
saúde coletiva, executar apenas atividades de clínica, sem atividades nos bairros e a sensação de inconveniência: “... achava que seria muito ruim”.

Ainda, neste grupo que manifestou expectativas frente ao Projeto, agrupamos algumas justificativas que mereceram destaque, sob a visão do estudante: aguardavam desenvolver atividades de ensino mais curativas que preventivas, sendo que esta última seria limitada a um estágio final, desenvolver atividades restritas ao consultório, não esperavam gostar e se envolver com estas atividades, sendo que obtivemos expressões comuns, como: “... achava que o curso desenvolvia-se dentro da universidade e que as pessoas vinham até a gente."

Por outro lado, alguns estudantes aguardavam desenvolver parte destas ações do Projeto, porque são inerentes a odontologia, sendo fundamental para a formação profissional e inclusive aprenderam que a equipe do PSF não se restringe ao médico, tendo a participação do dentista.

Finalmente, $18 \%$ dos estudantes responderam que o Projeto correspondia à sua expectativa, justificando que: havia Manual do Projeto disponível, há a necessidade de desenvolver atividades mais simples, a prevenção faz parte do curso de odontologia, o dentista tem que trabalhar com esta área, conhecia o Projeto por intermédio de outro estudante do curso e que a novidade apresentada foi desenvolver a parte clínica, dentro da universidade.

Os estudantes ao justificarem se esperavam desenvolver as atividades preconizadas pelo Projeto ressaltam que houve desmistificação da dificuldade pessoal em lidar com crianças, a prática comprovava o que era repassado na teoria, houve mais resultado que esperavam, enfim, que superou as expectativas. 
Apenas dois estudantes já possuíam informações sobre as atividades dizendo que as mesmas aconteceram conforme imaginavam, ressaltando que: não esperavam atuar fora do espaço da universidade e afirmam que participar do Projeto é prazeroso porque desenvolve várias atividades práticas.

Observamos polarização das expectativas em duas frentes. A primeira, quando o estudante não tem nenhuma expectativa, reforçando que sua referência da profissão é o modelo odontológico convencional, predominando ações clínicas desenvolvidas dentro do espaço da universidade. A segunda, quando o estudante apresenta expectativa centralizada em noções de prevenção e o caráter assistencialista. Neste segundo pólo é traçado o prazer e o sucesso inesperado que o Projeto causou associando teoria e prática, levando benefícios e havendo interação com a comunidade, integração do ciclo básico com o ciclo clínico, incluindo atenção nos domicílios, escolas, creches e demais equipamentos sociais, além da clínica a universidade, não se restringido a ações preventivas e de trabalho de campo típicos dos modelos presentes na maioria das universidades, na área de saúde bucal coletiva.

\subsubsection{Sobre a possibilidade de não participar do Projeto, caso suas disciplinas fossem optativas}

\footnotetext{
"Participaria porque esta é a realidade do Brasil."(Estudante de odontologia 13).

“... Sim. Participaria, porque aprendi a ter uma interação com a comunidade, diminuiu a minha timidez. Adquiri bastante conhecimento de forma gradativa...." (Estudante de odontologia 14).
}

Os 51 estudantes de odontologia manifestaram-se, inicialmente, positiva e unanimemente sobre a participação no Projeto, mesmo que suas disciplinas fossem optativas. Entretanto, ao realizarmos uma leitura detalhada das justificativas, 
observamos que $11 \%$ das opiniões são contraditórias, verificando que os estudantes optariam por eliminar pelo menos uma das disciplinas que compõem o Projeto.

Com base, então, nas respostas obtidas, identificamos as seguintes justificativas para participação do Projeto, segundo a ótica do estudante de odontologia, conforme Tabela 22.

Tabela 22 - Justificativas do estudante de odontologia para participação do Projeto Saúde Bucal Coletiva. Uberlândia, 2002

\section{JUSTIFICATIVAS PARA PARTICIPAÇão No PROJETO}

FREQÜÊNCIA $\%$

Fundamental para o conhecimento geral, de forma gradativa/ aprendizagem sobre Prevenção/ sobre técnicas de restauração/ sobre saúde coletiva/ saúde da família/ comunidade/ noção de coletividade/ visão mais ampla de assistência.

Contato e conhecimento da realidade e a condição de saúde bucal das comunidades mais pobres/ levar benefício concomitantemente para o estudante e para quem precisa da odontologia/ aprendizagem de abordagem diferenciada conforme a comunidade.

Facilita o contato e a relação com os pacientes e a interação com a comunidade/ desenvolve o lado mais humano da odontologia, a solidariedade/ experiência com paciente de todas as idades/ demonstrou evolução no trabalho/ desenvolve a conquista e manutenção do vínculo com os pacientes/ minora a timidez e contribui com a segurança na relação com o paciente.

Ressalvas para participação do Projeto.

Importância para a formação acadêmica e profissional.

$4 \quad 7$

Valorização curricular.

Promoveu aplicabilidade dos conhecimentos de saúde coletiva sem demagogia.

Preparação para o "Provão". 54 100

Total*

* - não corresponde ao número de estudantes, mas sim a número de razões apontadas.

Assim, observamos que o Projeto cumpriu com vários de seus objetivos, sobressaindo o desenvolvimento de diferentes capacidades, habilidades e 
conhecimentos proporcionados pelas suas atividades de ensino, segundo a visão do estudante, quais sejam: promoveu o conhecimento geral, de forma gradativa, a aprendizagem sobre técnicas tanto as preventivas quanto as clínicas e restauradoras, visão mais ampla de assistência, de saúde coletiva, saúde da família, comunidade e noção de coletividade.

Por outro lado, o estudante reconheceu que o Projeto viabilizou o contato e conhecimento da realidade e a condição de saúde bucal das comunidades mais pobres, levando benefícios, concomitantemente, para o estudante e para quem precisa da atenção odontológica, proporcionado à aprendizagem de abordagens diferenciadas, conforme a comunidade.

Outro aspecto, relevado pelo estudante referiu-se ao desenvolvimento da relação acadêmico de odontologia com o paciente, pois o Projeto facilitou o contato e a relação com os pacientes, em suas várias etapas, a interação com a comunidade, desenvolveu o lado mais humano da odontologia, a solidariedade, a experiência do estudante com pacientes de todas as idades, demonstrando evolução no trabalho, conquista e manutenção de vínculos com os pacientes, além de minorar a timidez e contribuir com a segurança na relação com o mesmo.

Soma-se em $19 \%$ o restante das justificativas, para participação do Projeto definida pela importância para a formação acadêmica e profissional, valorização curricular, promoção da aplicabilidade dos conhecimentos de saúde coletiva, sem demagogia, e a sensação de realização. Apareceram, também, as pretensões em atuar na área de saúde coletiva e a preparação para o "Provão".

Passamos a analisar as justificativas dos estudantes para não participação do Projeto ou de algumas de suas etapas, representando $11 \%$ das opiniões. Obtivemos 
$3 \%$ dos estudantes que realizariam apenas uma etapa do ciclo básico, correspondente as atividades extramuros, e todas as etapas do ciclo clínico que, efetivamente é o que interessa, considerando que: “... o clínico é a mão na massa”; “... passa a ter autonomia para atender”; “... não tem que ficar preenchendo aquele monte de fichas" “... porque as outras disciplinas não acrescentam nada”.

Observamos que $4 \%$ dos estudantes consideraram a maioria das etapas importantes para a profissão, mas não todas, eliminariam as visitas domiciliares e a intervenção na creche e fariam os conteúdos teóricos destas disciplinas; 2\% eliminariam a primeira etapa (segundo período), porque esta disciplina se repetirá nos outros períodos e $2 \%$ eliminariam apenas as visitas domiciliares, porque: "... gosta de resolver, ficar olhando sem poder fazer nada, não lhe satisfaz."

\title{
1.13.9 Sobre a compreensão do Programa de Saúde da Família - PSF
}

\begin{abstract}
"PSF é uma associação entre o mundo aqui (na universidade) e o mundo das pessoas ." (Estudante de odontologia 15).

"PSF é mercado de trabalho... Integra profissões. É solução porque o país cresceu desorganizado, e para a saúde chegar a todas as pessoas ele constituí-se na única forma..." (Estudante de odontologia 16).
\end{abstract}

A Tabela 23 nos proporciona as noções do estudante de odontologia, apreendidas através do Projeto Saúde Bucal Coletiva, sobre a estratégia do Programa de Saúde da Família, preconizada pelo Ministério da Saúde.

Tabela 23 - Noções do estudante de odontologia sobre o Programa de Saúde da Família. Uberlândia, 2002

\begin{tabular}{lccc}
\hline \hline NOÇÕES SOBRE O PSF & FREQÜÊNCIA & $\%$ \\
\hline $\begin{array}{l}\text { Visão restrita a prevenção da saúde bucal da família/ enfocando o } \\
\text { assistencialismo, o encaminhamento e a passividade da comunidade/ }\end{array}$ & 27 & 51 \\
\hline
\end{tabular}


restrita a prática pela prática (não associou a teoria a prática).

Atenção no domicílio para a família/ conscientiza para busca posterior da atenção clínica/ leva a informação para os desinformados/ esclarece e orienta a comunidade/ prioriza as pessoas mais carentes/ promove melhoria das condições de vida/ resultados a longo prazo.

Compreende as ações de promoção, prevenção e recuperação da saúde/ Prevenção com educação/ encaminhamento das pessoas para a rede do SUS/ promove investigação, diagnóstico para planejar e intervir/ promove resultados positivos/ PSF faz o elo entre a família e o profissional/ representa um novo mercado de trabalho para o dentista/ solução para o acesso a saúde.

(conclusão)

Compreende a ação de várias categorias profissionais/ Necessidade de atuação na escuta das pessoas/ suprir uma necessidade social/ levar saúde para as famílias/ representa uma estratégia do estado para colocar os profissionais em contato com a sociedade e possibilitar a saúde das pessoas/ promove a integração do dentista com a saúde pública.

$\begin{array}{lrr}\text { Total* }^{*} & 53 & 100\end{array}$

* - não corresponde ao número de estudantes, mas sim a número de noções relatadas.

Percebemos um quadro negativo, considerando que $51 \%$ das opiniões dos estudantes demonstram uma visão restrita desta estratégia, considerando-a concernente apenas com a prevenção à saúde (bucal) da família, enfocando o assistencialismo, o encaminhamento e a passividade da comunidade. Demonstraram limitar a compreensão do PSF às atividades de ensino que aplicaram, junto à comunidade, não articulando a práxis necessária ao seu entendimento, enquanto estratégia da organização da atenção básica, garantia do direito à saúde, a partir de acesso equânime e reorientação do modelo assistencial.

Algumas expressões utilizadas refletem esta categoria de opiniões relatadas anteriormente: “... é um programa assistencial que aborda a prevenção e se estende à família”; “... é desenvolvido dentro da comunidade, os profissionais de saúde vão até 
as famílias, orientam e atendem os pacientes que não podem ir ao centro de saúde. O dentista orienta a cerca da higiene bucal e prevenção"; “... grupo de pessoas que se reúnem para orientar as famílias sobre saúde, fazendo encaminhamentos”; “... ajudar famílias que não tem renda para utilizar o atendimento privado”; “... é um programa voltado para a classe mais baixa, de prevenção e tratamento para quem não tem acesso ao tratamento odontológico”; “... programa que abrange pessoas carentes e a prevenção”; “... é para a prevenção. Ensinar a escovar, como prevenir cárie. Não faz canal, mas prevenção mesmo”; “... é o dentista sair das quatro paredes e ir a creche, escola. Levar a informação até as pessoas, pois nem todas têm condições de ir ao dentista particular".

Em contraponto, $23 \%$ das opiniões avançaram na concepção do PSF, conseguindo articular as noções básicas do Programa ou, minimamente, apresentando aspectos básicos de sua estrutura e finalidade, como a importância da atenção no domicílio, voltada para a família, promover a conscientização para a busca da atenção clínica necessária, levar informações, esclarecer e orientar a comunidade, priorizando as pessoas mais carentes, a melhoria das condições de vida, compreendendo seus resultados em longo prazo.

As noções apresentadas caracterizam-se pelas seguintes frases: “... é um Programa que engloba não só a prevenção, mas o tratamento, previne educando, o profissional se desloca até as pessoas levando informações”; “... é um programa da família, filhos e pais, não podemos tratar a criança, se o pai não se envolver, é um trabalho para o futuro..."

Enfim, as duas últimas categorias de noções sobre o PSF, somam $26 \%$ das opiniões, avançando um pouco mais na compreensão desta estratégia. Compreende 
as ações de promoção, prevenção e recuperação da saúde, prevenção com educação, encaminhamento das pessoas para a rede do SUS, promove investigação, diagnóstico para planejar e intervir e promover resultados positivos, estabelecendo o elo entre a família e o profissional, representando um novo mercado de trabalho para o dentista e, principalmente, viabiliza o acesso a saúde.

Chamam a atenção duas concepções expressadas por estudantes de odontologia:

"PSF é uma associação entre o mundo aqui (na universidade) e o mundo das pessoas. Você encontra realidades muito diferentes, é uma estratégia que promove este elo." (Estudante de odontologia 17).

"PSF é mercado de trabalho. Integrar profissões. É solução porque o país cresceu desorganizado e para a saúde chegar a todas as pessoas ele constitui-se na única forma." (Estudante de odontologia 18).

Finalmente, a última concepção obteve $9 \%$ de noções sobre o PSF das opiniões, compreendendo as ações de várias categorias profissionais, necessidade de atuação na escuta das pessoas, suprir uma necessidade social, levar saúde para as famílias, representando uma estratégia do Estado para colocar os profissionais em contato com a sociedade e possibilitar a saúde das pessoas e promove a integração do dentista com a saúde pública.

A noção de que: “... na atuação com as famílias os cuidados não se voltam apenas para saúde bucal, mas para saúde geral e às vezes o dentista precisa agir como 'psicólogo', escutando os problemas e reclamações dos membros da família”, caracterizou-se em nossa opinião um olhar do estudante para o vínculo com o paciente e que a escuta, faz parte do inicio do processo de atenção e curas das doenças. 


\title{
1.13.10 Sobre a análise do Sistema Local de Saúde do Município de
}

\section{Uberlândia e o Papel do Odontólogo no SUS Brasileiro}

\author{
"Pode ser melhorado em relação ao acesso da \\ população. Os atendimentos mais complexos são \\ difíceis e burocráticos." (Estudante de odontologia \\ 19).
}

As opiniões, sobre o Sistema Local de Saúde de Uberlândia, apresentaram-se diferentes, na ótica do estudante de odontologia, sendo que as análises mais comumente encontradas, foram: não sabiam, não tinham conhecimento e informações, moravam há pouco tempo na cidade, perfazendo $20 \%$ de opiniões que desconhecem o sistema.

Em $22 \%$ das opiniões, classificaram o sistema de saúde da cidade de bom a muito bom, pelo fato do mesmo apresentar bons resultados e diminuição da incidência de cáries. Outro fator que contribuiu para esta classificação recai sobre o fato de alguns estudantes de odontologia terem passado pela experiência de usuários do SUS, para resolver doenças comuns, e terem sido bem atendidos. Apontaram, também o fato do sistema resolver situações de urgências associadas a trabalhos de prevenção. Elogiaram a organização das unidades de saúde que atendem pelo SUS, que visitaram, identificando-as como unidades limpas, bem localizadas e que possuem boas equipes. A presença e integração, junto ao SUS, dos hospitais de bairro, denominados Unidades de Atendimento Integrado - UAI, o apoio do Hospital das Clínicas da Universidade Federal de Uberlândia - UFU e a atenção da Clínica Odontológica da UNIT, foram na opinião dos mesmos exemplos de atenção com presteza aos pacientes do SUS. Foram estes os motivos apresentados para apreciação de Uberlândia como uma cidade modelo na assistência à saúde. Citaram, 
superficialmente, o que recordavam, quando visitaram as unidades de saúde e consideraram que Uberlândia tem uma assistência à saúde razoável.

Entretanto, $13 \%$ dos estudantes definem o Sistema como deficitário, apresentando falta de acesso aos usuários e de material básico para atendimento. Reconheceram que o sistema de saúde da cidade evolui, porém, ainda é fraco, necessitando de ampliação de serviços e atendimentos. Falaram sobre a experiência das visitas a alguns bairros, verificando, a partir da opinião das famílias, que os serviços do SUS eram bastante deficitários, com filas imensas. Notaram que houve defasagem na atenção à saúde do município, após mudança de gestão política, da última administração municipal, havendo retrocessos no sistema SUS, a partir do ano de 2001.

Finalizando, 4\% das opiniões classificaram o sistema em uma escala de horrível, passando por ruim até regular, alegando como motivo o fato do sistema estar centrado em urgências.

Resgatando, novamente, o perfil do estudante de odontologia, observamos que apesar de $66 \%$ dos mesmos residirem no município o desconhecimento da rede SUS demonstra, mais uma vez, predomínio de uma visão alienada e superficial de estudantes de classe média alta, que entraram em contato pela primeira vez com o sistema, a partir do Projeto.

"O dentista não é só para lidar com a boca. É para lidar com o ser humano, e conhecer sua história de vida." (Estudante de odontologia 20).

As respostas dos estudantes de odontologia, sobre o papel do odontólogo no Sistema Único de Saúde, foram agrupadas em quatro grupos, na Tabela 24, demonstraram que: $61 \%$ das opiniões apresentaram uma visão técnica deste papel, pouco articulada com os aspectos da saúde como qualidade de vida e determinação 
social, perpassando, apenas, pela prevenção, tratamento e restabelecimento da saúde da população, incluindo a necessidade de uma abordagem técnica e humanizada, concernente com a realidade encontrada; $17 \%$ das opiniões limitaram-se a uma visão restrita do papel do odontólogo, centrada na área de prevenção e educação voltadas para a boca; os $20 \%$ restantes enfocaram um papel de caráter assistencialista (10\%) e a atenção odontológica dependente da remuneração oferecida pelo governo (10\%). Apenas um estudante não respondeu alegando, desconhecimento do Sistema Único de Saúde.

Tabela 24 - Papel do odontólogo no Sistema Único de Saúde brasileiro, segundo o estudante de odontologia. Uberlândia, 2002

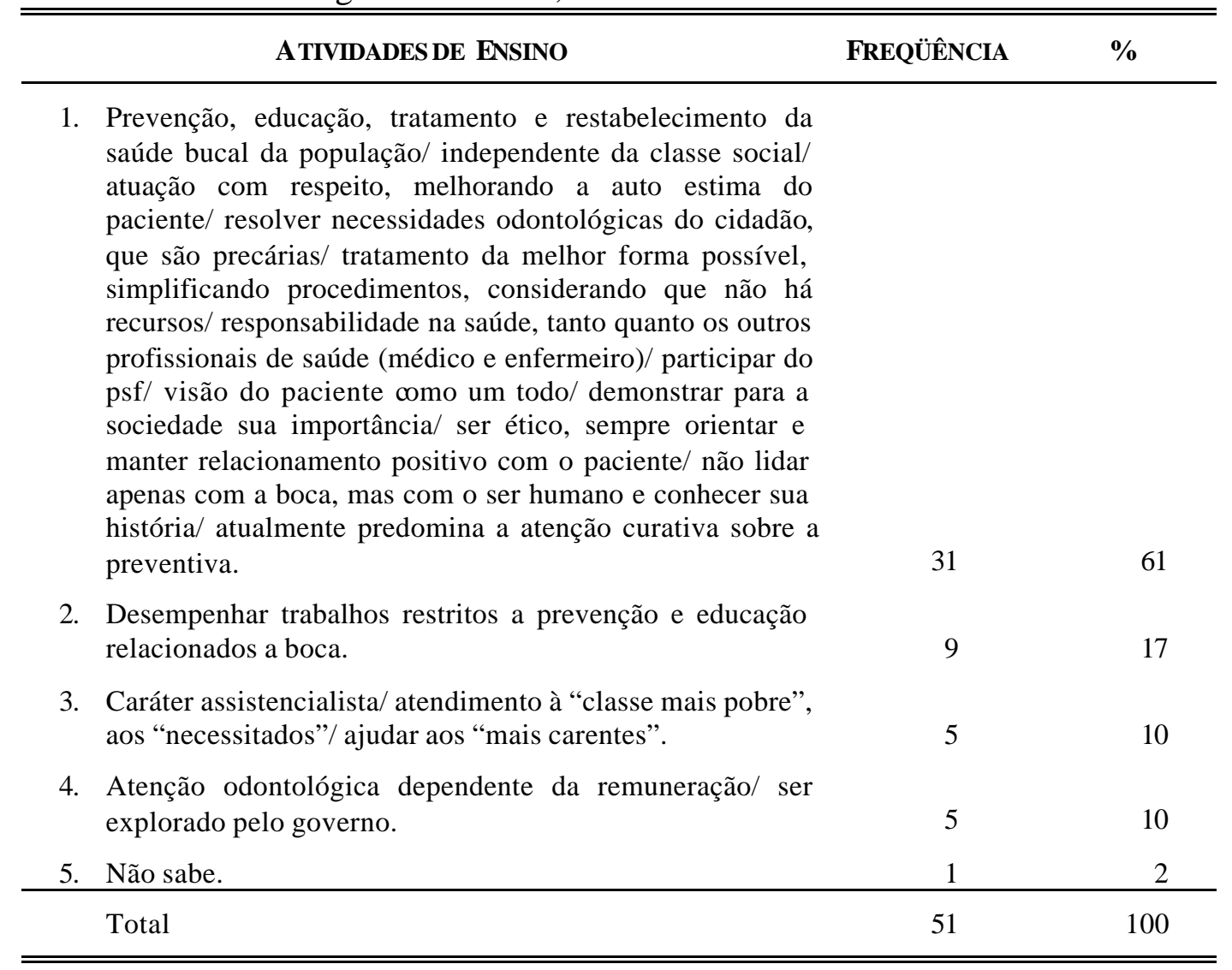

Chamou nossa atenção, o alto percentual de estudantes (10\%) com uma visão mercadológica da saúde, desconhecendo o direito à saúde, as responsabilidades sociais da profissão odontológica, atrelando a atenção oferecida pelo odontólogo à 
remuneração. Ficou evidenciado, também, o conflito entre sobrevivência profissional versus ética no atendimento, expressas nas respostas, tais como: “... seremos explorados pelo governo”; “... deveríamos ter satisfação em trabalhar”; “... poder receber bem pelo que se faz para poder receber bem a pessoa..."; “o SUS oferece uma remuneração fora dos padrões da formação profissional, evitando bons profissionais capacitados...”; “... o material de melhor qualidade, pelo custo, é muito difícil de ser usado pelo SUS, não discriminando o paciente do SUS...”; “o dentista tem que cumprir com suas obrigações financeiras (luz, água, encargos sociais, escola, filhos) e por isso, muitas vezes usa material de segunda...”; “... apesar da má remuneração o dentista pode contribuir na saúde coletiva”.

No decorrer dos últimos anos, novos conhecimentos têm levado a um melhor entendimento dos processos das doenças bucais e sua prevenção. Concordamos com Werner (1989) quando diz sobre o papel que o cirurgião dentista é capaz de desempenhar no controle destas doenças, que já é aceito nos mais adiantados centros de pesquisas odontológicas do mundo, como a Federação Dentária Internacional FDI e da Organização Mundial de Saúde (OMS), mostrando que a prevalência da cárie dentária em países industrializados tem diminuído.

Entretanto, Pinto (2000) ao analisar o "papel da odontologia" na melhoria da saúde bucal, demonstra que transcende o "papel do odontólogo". Refere-se aos serviços prestados diretamente pelos profissionais aos usuários, como um tratamento de emergência, restaurador, aplicação de selante ou flúor, dentre outros, denominando-os de "serviços de saúde pessoais", enquanto os "serviços de saúde não pessoais" incluem os que são colocados a disposição do público em larga escala, por meio de outros agentes, como por exemplo, fluoretação das águas e dentifrícios 
fluoretados. Conclui que: "O papel da odontologia na melhoria da saúde bucal está principalmente nos serviços não pessoais".

Acrescenta Pinto:

"Não é uma crítica aos serviços odontológicos dizer que eles tem menos efeito na saúde bucal do que fatores socioeconômicos e do que os serviços não pessoais. Cabe-lhes dentre outras obrigações, o papel de tranqüilizar, prover tratamento de emergência e restaurador, curar (as vezes), cuidar e confortar (sempre).” (NADANOVSKY e SHEIHAM, 1995).

\subsubsection{Sobre a visão do estudante em relação às crianças atendidas durante o Projeto}

"São crianças iguais a todas com o sonho de todas que é ser alguém na vida." (Estudante de odontologia 21).

As opiniões, dos estudantes de odontologia, sobre as crianças que atenderam durante o Projeto, são similares em $71 \%$ das respostas, sendo que ressaltaram as suas condições sociais, econômicas desfavorecidas e quadro de distribuição de doenças com alta prevalência de doenças bucais, a presença de alto risco de cárie, higiene bucal precária, a carência de afeto, atenção e cuidados familiares, a desinformação e a falta de acesso ao dentista. Os estudantes perceberam estas crianças com as seguintes características de personalidade: dóceis, carinhosas, interessadas, educadas, colaborativas e meigas. Registraram que as mesmas passam por privações, são crianças comuns, mas excluídas socialmente. Entretanto, demarcaram uma contradição: parecem felizes apesar da pobreza em que vivem.

Observamos que $22 \%$ das opiniões registraram diminuição do índice e tipo de cárie e aumento da consciência preventiva destas crianças, como resultado da 
aplicação do Projeto na escola. Notaram diferenças na prevalência de cárie entre crianças de sete e oito anos, quando comparadas com a prevalência nos adolescentes, sendo maior para as crianças de menores idades. Obtivemos $7 \%$ de outras respostas, classificadas como fora do contexto da pergunta, por constituírem-se em observações, tais como: “... aprendi um pouco sobre psicologia (...) e capacidade de lidar com crianças”, conforme Tabela 25.

Tabela 25 - Visão do estudante de odontologia sobre as crianças que atendeu durante o Projeto Saúde Bucal Coletiva. Uberlândia, 2002

VISÃO SOBRE AS CRIANÇAS ATENDIDAS NO PROJETO SAÚde BUCAL COLETIVA

1. Crianças desfavorecidas social, econômica e epidemiologicamente/ alto risco de cárie/ higiene bucal precária/ carentes de afeto, atenção e cuidados familiares/ desinformadas/ em sua maioria, não possuem escova dentária e não tem acesso ao dentista/ dóceis, carinhosas, interessadas, educadas, colaborativas e meigas/ passam por privações, são exc luídas socialmente/ parecem felizes apesar da pobreza em que vivem.

2. Registram diminuição do índice e tipo de cárie e aumento da consciência preventiva, como resultados da aplicação do Projeto na Escola/ notaram diferenças de prevalência de cárie .

3. Outras respostas (fora do contexto da pergunta).

Salientamos que alguns estudantes registraram encontrar estas crianças em uma situação mais desfavorável, em relação às noções de higiene bucal e geral, do que as suas expectativas, antes de atuar junto ao Projeto. Reconheceram que são crianças que necessitam de muito mais que tratamento odontológico e apesar da carência financeira, a cárie não é uma doença da pobreza, é possível saúde bucal, independente desta condição, desenvolvendo projetos como este.

Enfim, é estimulante para nós, sob a perspectiva da continuação e implementação deste Projeto, a seguinte visão expressada por um estudante de 
odontologia: "São crianças iguais a todas com o sonho de todas que é ser alguém na vida."

\subsubsection{Sobre a visão do estudante em relação às famílias atendidas durante o Projeto}

"Quem mantém as famílias, geralmente não estão presentes no momento da visita domiciliar, quem fica responsável é o filho de 11 ou 12 anos (...) não tem princípio de 'família'." (Estudante de odontologia 22).

A visão dos estudantes de odontologia, sobre as famílias que atenderam durante o Projeto, foram agrupadas em sete categorias, na Tabela 26, demonstrourse que $56 \%$ das opiniões apresentaram uma visão das famílias que corresponde as seguintes características: desfavorecidas sociais e economicamente e apresentando um quadro de distribuição de doenças com alta prevalência de doenças bucais, humildes, carentes, trabalhadoras, simples, numerosas, amigáveis, receptivas, acessíveis ao Projeto, com pouca instrução sobre tudo, desinformadas sobre saúde bucal e geral. Entretanto, notaram interesse em aprender, carência de atenção e carinho, dependentes do serviço público para atenção odontológica, moradia precária, alimentação inadequada, alto nível de desemprego e falta de acesso aos serviços básicos.

Obtivemos $22 \%$ das opiniões registrando que a família desconhece o Projeto do Ministério da Saúde - o PSF. Notaram, também, a não receptividade das famílias aos estudantes de odontologia, justificada pela definição de outras necessidades diferentes da saúde bucal, como necessidades básicas de alimentação, vestimenta, assim como interesse em outras doenças. Houve ressalvas ao desinteresse pelas atividades oferecidas pelo Projeto, não priorização da saúde bucal, inclusive pelas 
famílias responsáveis pelas crianças, que os estudantes de odontologia atenderam na escola.

Observamos apenas 7\% de visões voltadas para os aspectos sociológicos e antropológicos ligadas a mudança no perfil da família brasileira, quando ressaltam que encontraram uma família diferenciada do padrão "família nuclear", estabelecida pela sociedade, atribuindo responsabilidades domésticas aos filhos, nas faixas etárias de 11 e 12 anos de idade, desestruturadas moral e economicamente e ausência do pai em vários domicílios. Assim, como 7\% caracterizaram as famílias como acomodadas e sem vontade de melhorar. Finalmente observamos que $4 \%$ das opiniões consideram que esta família valoriza mais o atendimento realizado na clínica que no seu domicílio. Obtivemos apenas $4 \%$ de outros tipos de respostas, classificadas como fora do contexto da pergunta.

Tabela 26 - Visão do estudante de odontologia sobre as famílias que atendeu durante o Projeto Saúde Bucal Coletiva. Uberlândia, 2002

VISÃO SOBRE AS FAMÍLIAS ATENDIDAS NO Projetos Aúde BUCAL COLETIVA

1. Famílias desfavorecidas social, econômica e epidemiologicamente/ humildes, carentes, trabalhadoras, simples, numerosas, amigáveis, receptivas/ acessíveis ao projeto, interessadas em aprender/ pouca instrução sobre tudo/ desinformadas sobre saúde bucal e geral/ carentes de atenção e carinho/ dependentes do serviço público para atenção odontológica/ moradia precária, alimentação inadequada/ desemprego/ falta acesso aos serviços básicos.

2. Desconhecimento do PSF/ não receptivo aos estudantes de odontologia/ prioriza outras necessidades diferentes da saúde bucal/ desinteresse pelo Projeto/ não prioriza a saúde bucal, refletindo nos filhos que atendemos na escola.

3. Família diferenciada do "padrão nuclear", estabelecido pela sociedade/ Responsabilidades domésticas atribuídas aos filhos na faixa etária de 11 e 12 anos de idade/ desestruturadas/ pai ausente.

4. Acomodadas/ falta vontade de melhorar

5. Família valoriza mais o atendimento realizado na clínica que no seu domicílio. 
Encerraremos esta questão sobre a visão do estudante de odontologia sobre as famílias atendidas, apresentando um questionamento de um estudante, representando um conflito experenciado pelo mesmo em confronto com a realidade, proporcionada pelas atividades de ensino do Projeto:

“... em algumas famílias os lares são harmoniosos e limpos... não é porque é de classe baixa que reina a falta de higiene. Outras famílias têm aparelho de som de última geração, mas eram sujas e não se importavam com a higiene. Isso me fez questionar até que ponto a classe alta e média tem culpa dos problemas que acontecem e envolvem estas pessoas." (Estudante de odontologia 23).

Infelizmente, sob nossa perspectiva reflete uma concepção equivocada dos determinantes do processo saúde e doença, mas demonstra a inquietação e busca de respostas, antes, talvez, não estimuladas em situações do ensino acadêmico tradicional. Conforme referido acima, consideramos sua concepção equivocada, dos determinantes do processo saúde-doença, partindo da expressão pejorativa utilizada pelo estudante de odontologia ao referir-se a comunidade desfavorecida como "classe baixa" e a crítica entrelinhas ao acesso ao consumo do aparelho de som "de última geração", pré concebendo este como um produto supérfluo para esta comunidade. Além disto, ao questionar até que ponto a classe alta e média tem culpa dos problemas que acontecem e envolvem "estas pessoas", procura uma relação de causa - efeito simplista, sem contextualizar as condições sociais e econômicas que determinam o processo saúde e doença destas comunidades, assim como suas opções de lazer.

O estudante não conseguiu articular a ausência de lazer nestas comunidades, onde não é comum praça pública, áreas verdes, rios, quadra de esportes, clubes e 
demais espaços de lazer, esporte e cultura, sendo que o "aparelho de som de última geração" pode significar a única e exclusiva diversão de algumas destas famílias. Também, não conecta a determinação social da saúde/doença, evidenciada no aumento significativo da concentração de renda no país.

Talvez, a visão desarticulada e alienada do estudante de odontologia, não conseguindo desenvolver esta lógica de raciocínio, a partir das atividades de ensino propostas pelo Projeto, se justifique, considerando que estamos lidando com a possibilidade de influenciar a visão e percepção do aluno, através de um contato acadêmico, curricular, durante dois anos, confrontando com todos os valores construídos durante pelo menos 20 anos. Além disso, acrescentamos a determinação da influência familiar e dos modelos hegemônicos de compreensão da sociedade, vigentes em nosso país, desconsiderando, sempre que possível, a determinação política, econômica e social e individualizando a responsabilidade das condições de vida e saúde das comunidades sociais excluídas.

\subsubsection{Sobre as condições de saúde bucal das crianças e famílias atendidas} pelos estudantes de odontologia

“... na mesma rua havia muitas diferenças, algumas não tinham cáries, outras não escovavam os dentes..." (Estudante de odontologia 24).

“... tinham famílias que nem sabiam o que era escova de dentes e outras tinham uma escova para a casa toda..." (Estudante de odontologia 25).

“... não tinham escova, não tinham creme dental, não usam fio dental, não tem as vezes nem o que comer..." (Estudante de odontologia 26). 
As percepções dos estudantes de odontologia, sobre as condições de saúde bucal das crianças e das famílias atendidas, durante o Projeto, foram agrupadas em três categorias, na Tabela 27. Demonstrou-se que a maioria dos estudantes (73\%) converge suas opiniões classificando as condições encontradas como precárias, ruins e insatisfatórias, evidenciadas pela presença de grande quantidade de placa bacteriana, cáries e doenças periodontais, adultos desdentados e algumas crianças que já perderam os dentes permanentes. Ao se referirem sobre autocuidados, pelas crianças e as famílias, detectaram higienização deficitária, não utilização de fio dental (artigo elitizado), sendo que a maioria não possuía escova e pasta dental.

Em contrapartida, $14 \%$ das opiniões demonstraram a identificação de algumas famílias apresentando condições bucais boas e razoáveis, não possuindo ou apresentando poucas cáries.

Obtivemos, também, $13 \%$ de opiniões com a preocupação em ressaltar a diferença de condições piores encontradas para adultos, quando comparadas com as crianças. Tendo em vista a presença de cárie, destacaram a enorme necessidade de prótese dentária em adultos.

Tabela 27 - Condições de saúde bucal das crianças e das famílias atendidas, durante o Projeto Saúde Bucal Coletiva, segundo a percepção do estudante de odontologia. Uberlândia, 2002

$\begin{array}{ccc}\text { CONDIÇÕES DE SAÚDE BUCAL DAS } & \text { FREQÜÊNCIA } & \% \\ \text { CRIANÇAS E DAS FAMÍLIAS ATENDIDAS } & \%\end{array}$

1. Condições precárias e insatisfatórias (muita cárie e doenças periodontais), adultos desdentados e algumas crianças que já perderam os dentes/ higienização deficitária, não utilizam fio dental, a maioria não possui escova e pasta dental .

2. Algumas famílias apresentam condições bucais boas e razoáveis (não tinham cárie).

3. Condições piores para os adultos quando comparado com as crianças (em relação a presença de cárie)/ destaque para a grande necessidade de prótese dentária em adultos. 
Vale ressaltar algumas expressões utilizadas pelos estudantes, refletindo as percepções dos mesmos quanto às condições de saúde bucal das crianças e das famílias: “... têm situações que nos chocam...”; “... na mesma rua havia muitas diferenças, algumas não tinham cárie, outras não escovavam os dentes...”; “... ficavam dias sem escovar os dentes...”; “... tinham famílias que nem sabiam o que era escova de dentes e outras tinham uma escova para a casa toda...”; "as crianças eram muito maleáveis, deixavam entrar no mundo delas...”; “não considero que estavam desinformadas como era minha expectativa, pois os agentes comunitários de saúde (ACS) da prefeitura já haviam feito trabalho na região....”; "o descaso pelas famílias na região prevalecia, elas alegavam que sempre passa um ACS, mas que continuava do mesmo jeito...."; “sem o tratamento clínico, apenas o preventivo...”; “ a maioria usava prótese dental”.

Enfim, "não tinham escova, não tinham creme dental, não usam fio dental, não tem às vezes nem o que comer...."

As justificativas, comumente selecionadas, para estas condições encontradas supracitadas foram: ausência de informação sobre higienização adequada e condições financeiras para adquirir os elementos básicos da higienização: escova, pasta e fio dental; ausência de informações sobre as consequiências nocivas do não tratamento da cárie dental; falta de estímulo e da cultura da utilização dos autocuidados; ausência de políticas públicas e programas preventivos periódicos; padrão de vida e ausência de instrução; falta conscientização dos pais; diferença de valores ; cultura da procura ao dentista quanto há sintomatologia; falta interesse das famílias e do governo; falta acesso a atenção odontológica que priorize, inclusive, programas de 
acompanhamento das famílias e ausência de condições financeiras para custear o tratamento odontológico.

Um estudante compreendeu que: "se não fosse o Programa do SUS, a situação estaria pior....”

\subsubsection{Sobre as sugestões, críticas, dúvidas e observações formuladas pelo}

\section{estudante de odontologia}

"A equipe do programa é muito integrada e isso é muito importante (...) e a integração com o serviço de saúde aumenta o número de atendimentos, sendo possível mudar a consciência das pessoas, mudando a realidade." (Estudante de odontologia 27 ).

As sugestões mais freqüentes foram:

(1) O Projeto deve ampliar e ga rantir a atenção clínica restauradora para as famílias cadastradas, em todas as suas fases, através da construção ou adaptação de um local para atenção clínica restauradora das famílias, próximo às suas residências;

(2) Ampliar o número de crianças atendidas ma clínica e as etapas de ciclo clínico do Projeto;

(3) Substituir o domicílio, utilizado como espaço de atenção a saúde, por local específico para esta atenção;

(4) Dinamizar algumas aulas teóricas, com a utilização de materiais didáticos alternativos,como vídeos, despertando maior atenção dos estudantes;

(5) Manter a afinidade e união da equipe de docentes responsáveis pelo Projeto;

(6) Iniciar o ciclo clínico no primeiro período do curso de odontologia;

(7) Divulgar este Projeto para aplicação em outras universidades, pois ele serve como modelo. 
Chama a nossa atenção e converge com nossa visão, o fato do estudante vincular o êxito do Projeto com sua condução através de uma equipe de docentes afins e unidos.

Os alunos captaram duas questões importantes: a primeira sobre o reduzido acesso à atenção odontológica e a segunda demonstrando valorizar o ensinoaprendizagem promovido por este Projeto, sugerindo aonde o mesmo deveria ter suas ações ampliadas e garantidas à população. Por outro lado, o estudante de odontologia ainda não menciona como lutar por esta ampliação e garantia à saúde, da necessidade premente de articulação das unidades prestadoras dos serviços do SUS, inclusive da necessidade de incremento da articulação entre a UNIT e a Secretaria Municipal de Saúde, do município de Uberlândia.

No campo aberto para as críticas, elaboradas pelos estudantes de odontologia, obtivemos:

(1) Ausência de divulgação do Projeto e necessidade de ampliação da população atendida pelo mesmo;

(2) Na terceira etapa do Projeto, ao realizarmos a segunda visita ao bairro, ficamos com a sensação, muito grande, de frustração por não conseguir resolver o problema da família no momento;

(3) O Projeto é rico na teoria e na prática, contudo critíco as etapas das visitas domiciliares e da creche;

(4) A universidade deveria custear o transporte até os bairros;

(5) Falta empenho dos estudantes de odontologia no retorno às famílias. Aprofundamento das atividades desenvolvidas na creche. 
Obtivemos explicitada, apenas uma dúvida, de um estudante: "Houve encaminhamento das famílias, do bairro cadastrado, que necessitavam de tratamento odontológico ou estão sem tratamento?"

Consideramos, oportuno, responder à esta pergunta do estudante, neste momento da discussão dos dados, a partir de três vertentes analíticas: a primeira, mais objetiva, atestando que conseguimos o encaminhamento, parcial, para o atendimento na rede SUS, do município de Uberlândia, para maioria das crianças na faixa etária de 0 a 14 anos. Obtiveram seu atendimento odontológico garantido pelas equipes que prestam serviços nas unidades básicas de saúde e as voltadas para crianças em idade escolar, inclusive, oportunizados pelo período de férias escolares. Programando, previamente, estas equipes para atender ao cadastramento dos estudantes de odontologia da UNIT, conforme reportagem jornalística, de veiculação no município (Anexo I).

Contudo, faz-se necessário registrar que a integração entre UNIT e Secretaria Municipal de Saúde, garantindo o atendimento odontológico destas crianças cadastradas, não esta sendo mais viabilizado, desde fevereiro de 2001, após a mudança de gestão política do município. Desde esta época, o diálogo entre o coordenador do Curso de Odontologia, a equipe de docentes responsáveis pelo Projeto da UNIT com o gestor do SUS do município, não tem sido realizado, apesar de nossas insistentes solicitações de integração docente - assistencial.

Para a segunda vertente, observamos a necessidade de resguardamos, junto aos estudantes, que um dos princípios do Projeto, inclui a defesa de um caráter informativo, junto às famílias para utilizarem a rede SUS. Exercitando, assim, seu direito de cidadania, buscando a melhoria do acesso a estes serviços, a partir da 
compreensão das famílias, da necessidade de mobilização, viabilizando a garantia do direito a saúde, com dignidade e qualidade, através do SUS. A compreensão desta questão é considerada por nós crucial, pois procura evitar um caráter assistencialista, tanto do Projeto, quanto do papel do estudante dentro do mesmo.

A terceira e última vertente, leva-nos a reflexão dos motivos que levaram o aluno elaborar este questionamento: faltou oportunidade ou talvez constrangimento em questionar diretamente, junto aos docentes? O momento da pesquisa resgatou e oportunizou a dúvida? Ou a resolutividade do Projeto é considerada inerente a efetivação da atenção clínica odontológica, negando contribuição das outras atividades desenvolvidas junto à família?

Enfim, encerrando o último campo do questionário aplicado, verificamos as seguintes observações formuladas pelos estudantes e manteremos as expressões utilizadas pelos mesmos:

- "Gostei de tudo";

- "O Programa deve continuar porque foi muito bom e aprendi muito. O aluno cresce junto conhecendo uma realidade totalmente diferente da sua...";

- "É um trabalho muito bom e tem acrescentado muito na visão enquanto odontólogo.”;

- "Às vezes cria uma expectativa na população, mas a mesma foi atendida";

- “... que continue";

- "Espera que o programa continue porque é essencial";

- "O trabalho foi muito instrutivo, esclarecedor, pois percebeu a realidade das comunidades"; 
- “A equipe do programa é muito integrada e isso é muito importante... e a integração com o serviço de saúde aumenta o número de atendimentos, sendo possível mudar a consciência das pessoas, mudando a realidade";

- "O programa é muito bom. As professoras competentes e deverá ser dada continuidade, pois oferece conhecimento aos alunos e a comunidade";

- "Eu admiro as pessoas que se envolvem nesse tipo de trabalho e gostaria de fazer parte do mesmo";

- "Considero que as disciplinas foram seqüenciais (...) acho que poderia estar mais tempo na clínica. Considero que contribuiu muito na minha aprendizagem e maturidade...". 


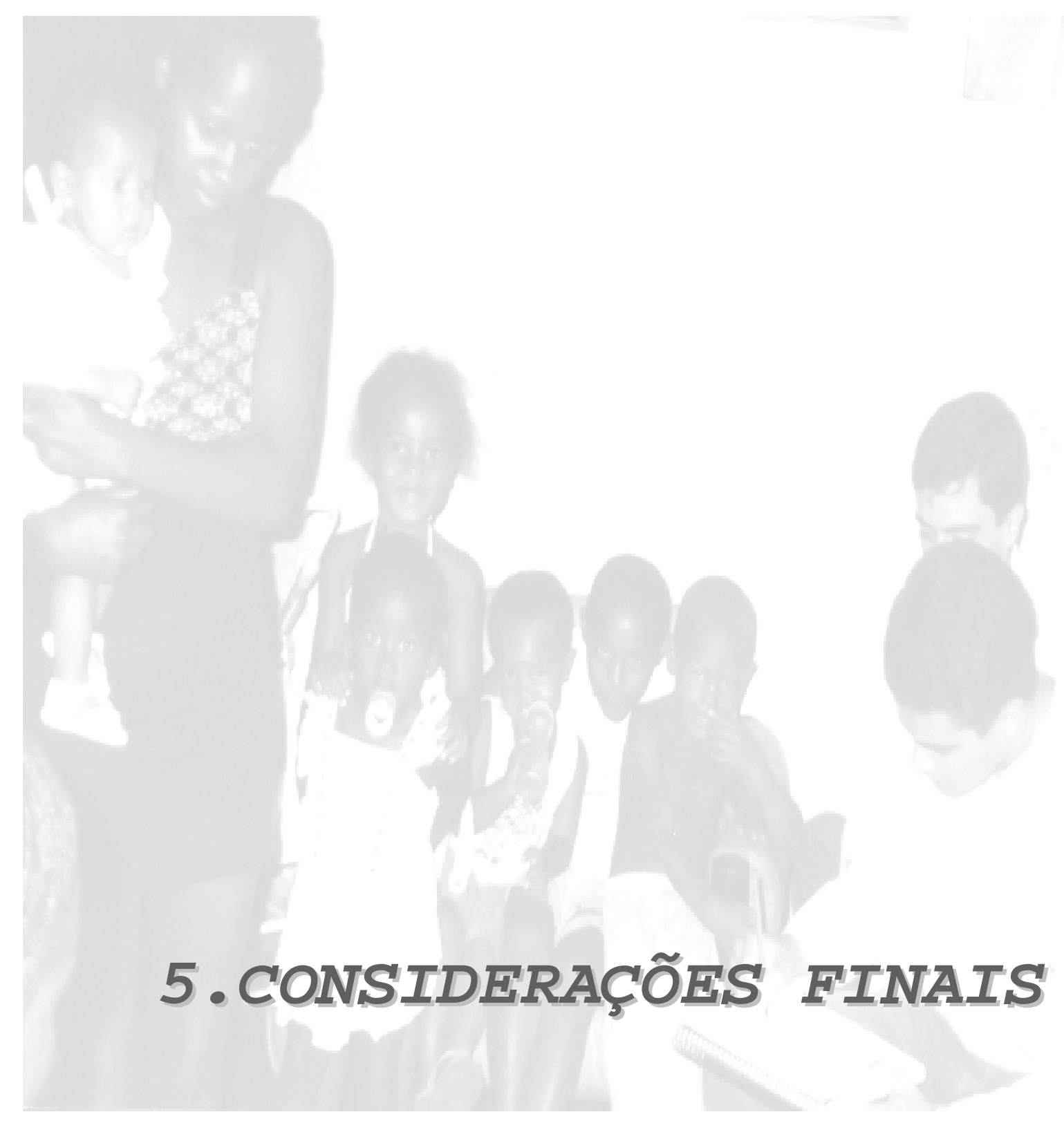


Conforme explicitado em nossos objetivos e relatado na discussão dos resultados da pesquisa, versando sobre o perfil social do estudante de odontologia e a abrangência do "Projeto Saúde Bucal Coletiva - Saúde e Cidadania", este trabalho possibilitournos a caracterização do Projeto, em seus aspectos pedagógicos e operacionais, assim como sua contribuição para a formação do estudante de odontologia, identificando suas potencialidades e limitações, sob a ótica do aluno.

Assim, analisamos as opiniões de $86 \%$ dos estudantes da primeira turma de graduandos, do Curso de Odontologia do Centro Universitário do Triângulo, uma instituição privada, sobre as questões pertinentes ao Projeto.

O leitor que nos acompanhou nesta longa caminhada, precisa estar ciente que neste momento final, será impossível não nos expormos. Buscaremos a objetividade, mas será difícil não tomar partido, confirmando a impossibilidade da neutralidade do pesquisador. Pedimos que relembrem isto: ocupamos neste trabalho o papel de pesquisadora, de pesquisada e já fomos, como os sujeitos desta pesquisa, em um tempo que parece remoto, 18 anos atrás, objeto primeiro do ensino aprendizagem enquanto ex-estudante de odontologia. Deste modo, usamos durante o desenvolvimento deste trabalho, três óculos, que nos permitiram visões diferenciadas que se complementaram.

Assim, enquanto pesquisadora, penso o ensino aprendizagem como Alves (2002, p.6):

"Toda experiência de aprendizagem se inicia com uma experiência afetiva... Não confundir afeto com beijinhos e carinhos. Afeto, do latim "affetare", quer dizer "ir atrás". É o movimento da alma na busca do objeto de sua fome...”

Como pesquisada, fazendo parte do grupo de docentes responsáveis por este Projeto desenvolvido, aprendo, novamente, com Alves (2002, p.6), sobre os motivos 
que nos levaram a encarar o desafio de sua implementação: "É a fome que faz a alma voar em busca do fruto sonhado”. Assim, partilhamos de um movimento de alma, juntamente com as outras docentes, na busca do objeto de nossa fome, parafraseando Unamuno (apud ALVES, 2002): “Saber por saber: isso é inumano... “ "A tarefa do professor é a mesma da cozinheira: antes de dar a faca e queijo ao aluno, provocar a fome..." (ALVES, 2002). Foi a fome que nos impulsionou neste empreendimento de ajudar formar um profissional sensível às questões sociais, concebendo saúde como direito e voltando-se para a sua manutenção e prevenção. Percebemos que "Fome é afeto", e o movimento em busca do como tornar o sonho viável nasce do afeto e da fome.

Deste modo, nos víamos, inicialmente, assustadas e inseguras ao levar um grupo de sessenta estudantes, cursando o primeiro ano do curso de odontologia, a um bairro socialmente excluído, para inteirar-se com sua comunidade, considerando que a mídia reforça, que neste espaço nós somos suscetíveis e vulneráveis a todo tipo de violência, sem o menor controle sobre o que nos possa acontecer. Juntava se a isto, o peso da relação institucional que recaia sobre nós quanto a responsabilidade sobre a segurança dos alunos, frente a qualquer problema que viesse ocorrer com os jovens estudantes no cumprimento de atividades extraclasse.

Nossa experiência demonstrou, superando as nossas expectativas, que houve boa receptividade e interesse das famílias destas comunidades em nos receber. Não temos registro de nenhum incidente prejudicial à integridade física e moral de nossos alunos, desde que vimos atuando neste Projeto, a partir de 1999.

Vale ressaltar, a necessidade de resguardarmos enquanto recomendação, se cogitada a aplicação do Projeto em outros municípios, as diferenças entre um bairro 
de uma cidade de médio porte, como Uberlândia, em relação à periferia dos grandes centros urbanos, onde a violência está agregada ao crime organizado.

Outro aspecto relevante diz respeito a nossa cautela no translado dos alunos até o bairro (sendo realizado por "vans" alugadas) e na padronização do vestuário dos mesmos, sempre trajados com jalecos brancos e crachás de identificação acadêmica, além de orientados quanto à postura e habilidades necessárias em trabalho de campo, representando, evidentemente, para esta comunidade um grupo socialmente reconhecido como o "pessoal da saúde".

Obtivemos vários registros sobre o impacto dos estudantes, frente à realidade encontrada, como, por exemplos alunos que não conseguiram conter as lágrimas ao ver uma adolescente, portadora de "síndrome de down", sem visão ocular, sendo criada amarrada em sua cama, junto às galinhas, gatos, cachorros e porcos, dividindo sua comida com os animais. Por outro lado, os alunos relatando o quão passaram a valorizar sua condição de vida ao se depararem com cenas comuns de crianças menores sendo criadas pelos irmãos de onze e doze anos, tendo, na maioria das vezes, o irmão como preceptor, enquanto seus pais têm jornada dupla de trabalho, ficando fora de casa, durante o período diurno, ora deparando-se com a crueza das condições sociais e culturais, quando viram mães colocando "cachaça" na mamadeira de seus filhos, para passar a fome e o choro, ou mesmo lidando com a desinformação de adolescentes, que dividem uma única cartela de anticoncepcionais, achando que estão se prevenido contra a gravidez indesejada...

Foram inúmeros os relatos dos estudantes enfrentando e sensibilizando - se com uma gama de realidades que os fazem refletir e valorizar as suas condições sociais e econômicas. Pareceu-nos bastante relevante a grande quantidade de relatos 
reforçando a importância da interação entre teoria e prática, apontando a práxis como o espaço onde o conhecimento se constrói. Além disto, demonstraram preferência pela atuação prática, quando comparada com as aulas teóricas.

Aparecem de forma positiva e salientada pelos estudantes a continuidade e encadeamento das ações propostas pelo Projeto, durante os períodos subseqüentes do curso, embora as visitas e trabalhos domiciliares terem sido apontados como repetitivos. Concluem que não basta cadastrar, identificar, diagnosticar e sensibilizarse. É preciso preparar um plano de ação frente à realidade encontrada.

Assim ao lidarem com a realidade os estudantes perceberam que a saúde bucal "caiu do pedestal" e não representa prioridade para a família, tornando-se ínfima, para quem tem fome e a maioria das necessidades básicas não resolvidas. O fio dental é constatado como artigo supérfluo e elitizado, escova de dente um objeto de uso dilatado, por vários meses e as vezes uma mesma escova é de uso coletivo para toda a família, sendo que diagnosticar adultos possuindo dentição completa, não mutilada, correspondeu à uma verdadeira utopia.

Neste panorama das mazelas do processo saúde e doença, enquanto questão social, nem todas as situações encontradas estavam perdidas e predestinadas ao fatalismo desalentador em que vive grande parte das comunidades, com as quais atuamos. Os estudantes se depararam com residências asseadas, famílias com qualidade de vida, com hortas bem cuidadas, úteis à nutrição e terapêuticas (fitoterápicas) e a cooperação entre vizinhos, demonstrando que ao (re) dividirem as suas migalhas, trocando pó de café por copo de arroz, sobrevivem cultivando a cultura e a sabedoria da generosidade, doando o que lhes é útil e não apenas o que lhes sobram. 
$\mathrm{Na}$ área da saúde bucal, perceberam a menor prevalência de cáries em crianças em idade escolar, assim como a maior facilidade de acesso aos serviços odontológicos do SUS, demarcando o predomínio e quase exclusividade de atenção pública odontológica, voltada para esta faixa etária. Perceberam, também, a doença bucal como uma manifestação comportamental e não somente como "doença da pobreza", pois, ao aplicarem um programa de prevenção, que se propõe a redimensionar o modelo odontológico tradicional, centrado na cura, com crianças desta faixa etária supracitada, acompanham e vinculam - se as mesmas constatando a possibilidade do êxito da prevenção, independente de demais fatores conjunturais.

A atenção clínica, destas crianças, pautou-se pelo controle epidemiológico da cárie, baseado no risco individual de cada criança, adequando, inicialmente, o meio bucal das mesmas e aplicando o conceito de equidade afim de referenciá-las para a atenção curativa. Constataram, então, a possibilidade do controle da doença, sua reversibilidade em algumas situações e a efetividade da promoção em saúde, sem demagogia.

Em nosso terceiro ângulo de visão da problemática estudada, como exestudante de graduação do curso de odontologia, identificamo-nos, parcialmente, com o perfil do estudante, ingressante ao curso de odontologia da UNIT, quanto aos seguintes aspectos: a influência da convivência e tradição familiar, determinando a escolha da carreira odontológica e devido ao fato de ser um curso da área da saúde ou das ciências biológicas; o ingresso em idade jovem à graduação, em uma faixa etária com menos de 20 anos, a feminização da profissão, os pais com nível de escolaridade superior, do aluno residente no mesmo município da universidade, em imóveis próprios e oriundos, em sua grande maioria, de classe social de maior poder 
aquisitivo. A maioria, também, cursou o $2^{\circ}$ grau em escola particular, sendo que o curso de odontologia foi a primeira opção de graduação. Participaram, freqüentemente, de outros cursos e de atividades fora da universidade como os de língua estrangeira e a prática esportiva.

Enfim, nosso perfil enquanto ex-estudante de odontologia, ingressante em 1981 na universidade, é similar ao perfil do aluno estudado em vários aspectos como o fato de pertencerem à classe média alta, possibilitando conseqüentemente várias oportunidades de crescimento pessoal e acesso cultural e incluindo-se hoje a informática.

Encontramos, também, alguns aspectos do perfil social do estudante de odontologia da UNIT, que diferem do nosso perfil, como o fato de não exercerem atividade remunerada, enquanto cursam a graduação de terem experenciado mais de um vestibular e alimentarem o desejo de uma formação profissional voltada para o mercado de trabalho, concernente com a tendência encontrada de uma visão alienada e imatura sobre as desigualdades ao acesso à saúde e da responsabilidade social da profissão.

Assim, tocar neste aspecto das diferenças de perfis entre a pesquisadora e os alunos da UNIT, tornou-se pertinente para as nossas considerações, tendo em vista nossa constatação de que o aluno ingressante na UNIT pretende, em sua grande maioria, adquirir uma formação profissional, voltando primordialmente sua atuação segundo o mercado de trabalho, desconsiderando os aspectos da formação científica cultural mais ampla e voltada para a pesquisa e solução dos problemas odontológicos, do conjunto da sociedade. 
Tal visão constituiu-se em uma limitação em relação às disciplinas relativas às questões filosóficas e sociais, como saúde bucal coletiva e as ciências sociais aplicadas à saúde, causando sobre este estudante um grande impacto, uma vez que este tem uma referência odontológica centrada na clínica privada, no consultório particular, na cura das doenças e, sobretudo, na visão de saúde como "mercadoria" a ser comercializada. Evidencia, também, reforço do status quo estabelecido pela visão hegemônica que sempre pautou a formação do profissional de saúde e a visão idealizada do modelo odontológico tradicional, motivo comum apontado para a escolha da profissão, através da tradição familiar.

Por outro lado, o fato relativo à liberalidade da profissão odontológica e o retorno financeiro propiciado pela profissão, conforme relatado como os primeiros motivos para estudantes de outras universidades, não se constituírem em razões apontadas pelos estudantes de odontologia da UNIT, demonstra tendência de alteração frente à imagem da profissão. Assim, demarca a influência da conjuntura econômica atual, configurando restrições à liberalidade da profissão e limitações nas possibilidades de atratividade financeira no mercado de trabalho da área odontológica.

Nesta perspectiva, vale lembrar que a liberalidade da profissão odontológica, no Brasil, encontra-se comprometida em conseqüência não só do excesso do contingente profissional no mercado de trabalho, mas, também, devido a tendência ao controle e eliminação do problema da cárie no país, através do uso de pasta de dente e rede de abastecimento de água fluoretada e a disponibilidade dos programas públicos odontológicos voltados para a idade escolar, tem provocado abalos na prática profissional e conseqüentemente nos mercados de trabalho, uma vez que 
eliminado o principal objeto de trabalho da odontologia, conforme observado por Teixeira (1995) em relação aos países desenvolvidos.

Assim o ponto que salientamos é que o Projeto, por si só, não pode almejar a transformação das práticas e postura deste estudante, após se graduar, pois, significaria não reconhecer a determinação, de pelos menos vinte anos, do convívio familiar, dos valores societais e culturais deste aluno, assim como das regras de sobrevivência profissional, que o próprio mercado de trabalho irá imputar-lhe ao iniciar o exercício da profissão, em nosso país.

Outro fator preponderante traduz-se no fato de que se trata ainda de um Projeto dentro do curso de odontologia, diferentemente da proposta UNI - Kellogg, por exemplo, que preconiza toda uma reestruturação curricular, em torno de proposta semelhante.

Vale ressaltar, que considerando o saldo positivo encontrado nos resultados deste Projeto e sua similaridade com os propósitos do UNI - Kellogg, seria recomendável, se cogitada adaptações ao projeto pedagógico curricular do curso de odontologia da UNIT, que se considerasse a positividade das experiências já implementadas em sua estrutura curricular, como a que ocorre com o Projeto Saúde Bucal Coletiva, envolvendo inicialmente as unidades de odontologia coletiva, orientação profissional e ciências sociais aplicadas à saúde. Entendemos que este Projeto demonstrou coerência e conveniência para sua utilização mais ampla dentro do curso de odontologia, inclusive como já vem ocorrendo com a integração ao Projeto da disciplina de pediatria no ciclo clínico ou o que recomendamos: o Centro Universitário do Triângulo - UNIT implementar a reforma curricular proposta pelo Projeto UNI - Kellogg. 
Os aspectos considerados, pelo estudante de odontologia, de maiores contribuições do Projeto Saúde Bucal Coletiva, foram atribuídos às ações desenvolvidas, durante o ciclo clínico. A opinião dos estudantes foi unânime ao consideraram que este ciclo do Projeto proporciona o contato "profissional", levando à visão ampla das fases vivenciadas, possibilitando colocar em prática o que foi planejado, desenvolvendo habilidades inerentes a atenção clínica e introdução de alternativas de tratamento, sob a perspectiva da saúde pública.

A maior contribuição atribuída ao ciclo clínico, foi seguida pelos aspectos do ciclo básico, referentes ao primeiro contato do estudante com uma realidade de uma comunidade socialmente excluída, demonstrando que o Projeto insere o estudante de odontologia, oriundos, em sua maioria, de classes sociais de maior poder aquisitivo, em uma realidade econômica, social e cultural muito diferente da que vivenciam, possibilitando o contato com uma vertente do mercado de trabalho, sensibilizando-os para esta realidade estranha.

O Projeto constitui-se, também, nos primeiros contatos efetivos e práticos com aspectos da saúde bucal coletiva, com diferentes necessidades odontológicas de uma mesma comunidade, e as noções de sociologia. Incutiu a necessidade de uma postura preventiva e socializada no agir profissional, alertando-o para a importância do SUS e da estratégia de saúde da família.

Contudo, mesmo o Projeto buscando demonstrar o avanço da política oficial de saúde - o SUS, da estratégia de saúde da família, da epidemiologia e da cariologia e novas tendências no agir do processo saúde e doenças bucais, definindo um programa de prevenção que se propõe a redimensionar o modelo odontológico tradicional, apesar de sensibiliza-lo não seduz, totalmente, o estudante como o faz a 
atenção clínica curativa, mas cria um espaço no processo de ensino aprendizagem de reflexão crítica sobre a odontologia e permite a atuação dos estudantes em saúde bucal coletiva com populações discriminadas e carentes.

Há que se refletir a necessidade do grupo de docentes desenvolver o uso de tecnologia apropriada, junto à família, viabilizando, a execução de alguns procedimentos odontológicos mais simples no domicílio, constituindo-se em apontamentos dignos de ajustes ao Projeto. Isto representa potencializar novos espaços de atuação da odontologia, que devem ser implementados, para maior resolutividade das ações da equipe odontológica em nível de atenção primária.

Verificamos, também, que alguns relatos pertinentes apontando fragilidades operacionais do Projeto, merecendo destaque os horários desencontrados entre estudantes e famílias a serem visitadas, limitações das ações no domicílio e repetição de ações, sugerem a revisão destes aspectos mencionados.

Ao final desta nossa caminhada, que já aponta para novas inquietações e necessárias investigações, reafirmou para nós, que a perspectiva deste Projeto estudado, de procurar saídas tangenciando o elitismo que sempre pautou a formação e atuação do profissional de odontologia, representa a possibilidade da odontologia transcender o seu sucesso atualmente limitado à odontologia liberal e de mercado, baseado no atendimento a camadas sociais privilegiadas, para tornar seus serviços acessíveis à população em geral, sob uma perspectiva humanista. Assim, compreendemos que esta dissertação conseguiu demonstrar um caminho viável para a consolidação da praticidade social da saúde bucal coletiva, na formação do profissional de odontologia. 


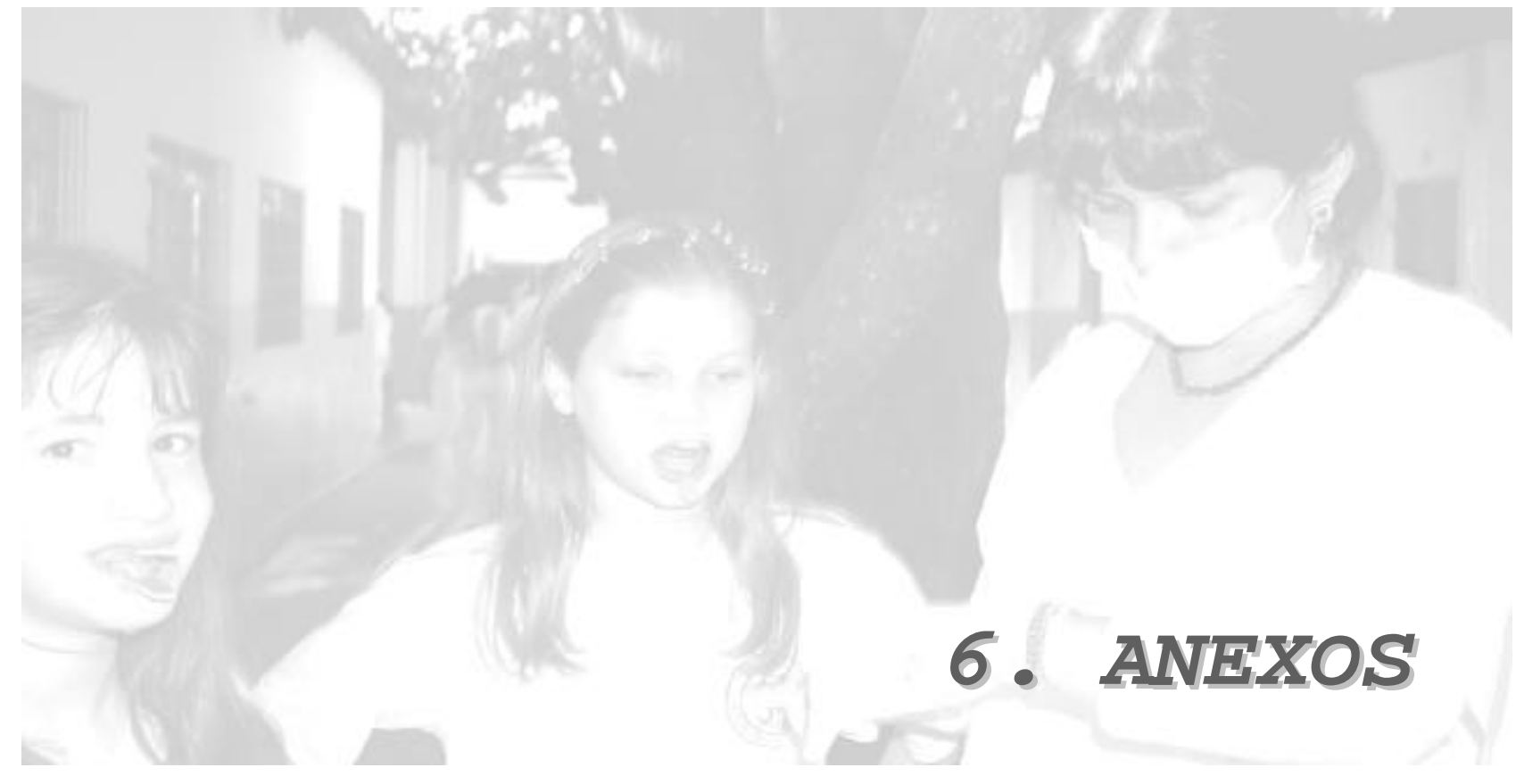




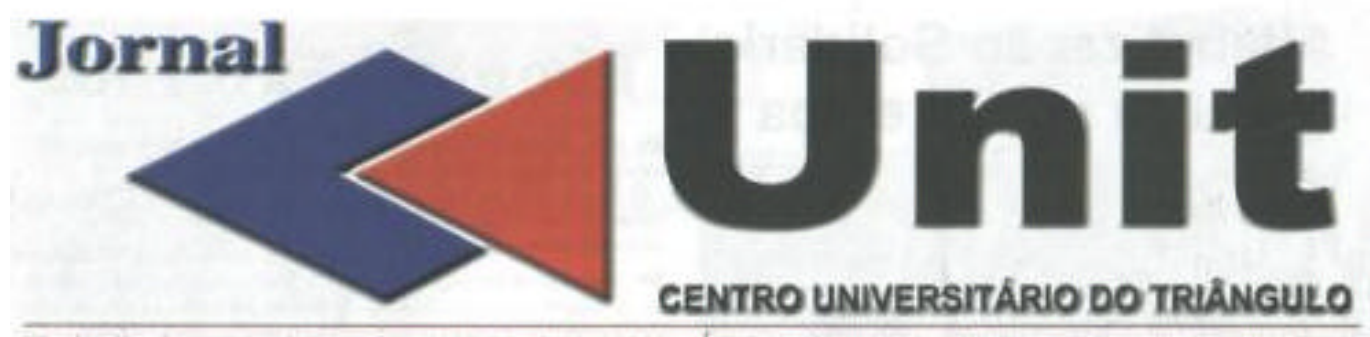

Uberlàndia, Araguari e Araxá - Ano 7 Edição n $n^{\circ} 61$ / 2000 - Orgão de Comunicaçăo do Centro Universitário do Triảngulo

\section{Projeto Saúde e Cidadania entusiasma alunos}

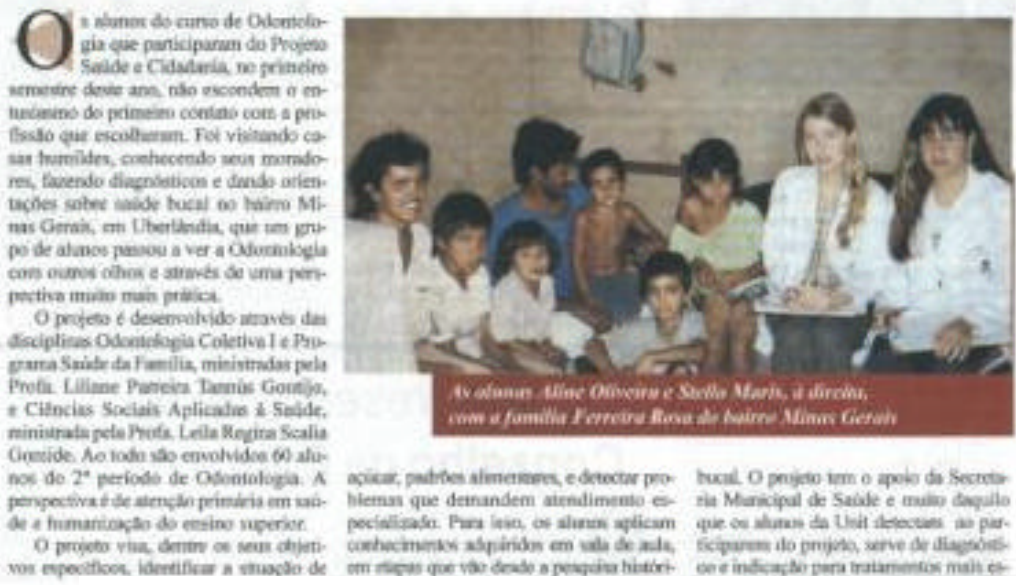

\section{Alunos acreditam que 0 resultado é uma lição de vida}

Para o aluno Frahn Thiago Sä Buso, jeto fez coan que os alunos conhecesparticipar do projeto fol uma liçso de sem outra realidade. "Aprendemos mui. vida, principalmente pelo conhecimen- to, conhecendo virios tipos de pessous.

to de uma realidade muito diferente da Os mesmos tipos de pessoas que ireque normaimente é vista nas aulas do curso. "Lâ, nós chegamos a ver fanili. as que custam a sobreviver com um salärio minimo. Prá eles, o mais importante é estarem vivos. E prá nós, foi muito bom colocarmos em prática duas disciplinas e aprendermos a lidar com esses futuros pacientes", relata ele.

A aluna Michelly Akemi Hamada avalia que a participaçato no projeto traz muitos resultados importantes, como o de perceber o quanto a Odontologia é essencial, principalmente entre as populaçoes mais carentes. Jik a aluna Erika Cruvinel afirma que participar do promos atender no futuro," relata.

$\Lambda$ aluna Patricia Cristina da Mita Ri. beiro avalia que a participacto no projeto possibilita uma vislo mais integral do paciente, atravís do conhecimento do meio no qual ele esta inserido. "O paciente nấo é só a boca. mas também o meio ent que ele vive. E nesse campo, as duas disciplinas têm uma grande interaçăo. Acredito que para todos que participaram houve crescimento, pois tivermos a oportunida de de conhecer a realidade que muitas vezes nilo se quer ver, que se ignona. Vimos que a teoria é uma coiva, na pritica é outra", finaliza ela. 


\section{ANEXO B}

Projeto Saúde e Cidadania, segundo os períodos do curso de odontologia, objetivos da disciplina, atividades práticas e local das mesmas

\begin{tabular}{|c|c|c|c|}
\hline Nome & Objetivos da Disciplina & Atividades Práticas & $\begin{array}{l}\text { Local } \\
\text { Atividades } \\
\text { Práticas }\end{array}$ \\
\hline $\begin{array}{l}\text { Odontologia } \\
\text { Coletiva } \\
\text { I/Programa } \\
\text { Saúde da } \\
\text { Família/ } \\
\mathbf{2}^{\mathbf{0}} \text { Período }\end{array}$ & $\begin{array}{l}\text { Oferecer subsídios para o graduando desenvolver atuação na área de saúde bucal coletiva, } \\
\text { capacitando-o para racionalizar e refletir o papel do cirurgião dentista na sociedade civil e } \\
\text { Estado, na formulação e direcionamento da política de saúde - o SUS. Compreender os } \\
\text { determinantes do perfil de morbimortalidade, em uma comunidade socialmente excluída, } \\
\text { previamente estabelecida, através da vivência em etapas do cadastramento, diagnóstico e } \\
\text { mapeamento da Estratégia de Saúde da Família, viabilizando o conhecimento teórico associado } \\
\text { a uma experiência local. }\end{array}$ & \multirow{2}{*}{$\begin{array}{l}\text { Conhecer o funcionamento e as necessidades dos serviços } \\
\text { da rede básica do SUS. Identificação dos problemas de } \\
\text { saúde prevalentes em uma comunidade socialmente } \\
\text { excluída, através de visitas domiciliares, cadastramento e } \\
\text { elaboração de um Plano de Ação. }\end{array}$} & \multirow{2}{*}{$\begin{array}{l}\text { Domicílios, } \\
\text { Equipamentos sociais } \\
\text { e Unidades de Saúde } \\
\text { da Rede Básica do } \\
\text { SUS }\end{array}$} \\
\hline $\begin{array}{l}\text { Ciências } \\
\text { Sociais } \\
\text { Aplicadas à } \\
\text { Saúde/ } \\
\mathbf{2}^{\mathbf{0}} \text { Período }\end{array}$ & $\begin{array}{l}\text { Proporcionar aos alunos, condições para que, a partir da produção contemporânea na área das } \\
\text { ciências sociais, eles possam compreender a relação entre a Sociedade/Corpo/Saúde/ } \\
\text { Instituições, analisadas sob a perspectiva do poder, contemplando a questão da "cidadania" na } \\
\text { sociedade brasileira, discutindo o papel social do profissional da saúde, e em especial o da } \\
\text { saúde bucal no contexto do Brasil do séc. XXI. }\end{array}$ & & \\
\hline $\begin{array}{l}\text { Odontologia } \\
\text { Coletiva II/ } \mathbf{3}^{\mathbf{o}} \\
\text { Período }\end{array}$ & $\begin{array}{l}\text { Promover a integração do aluno com a comunidade escolar, dinamizando o ensino dos aspectos } \\
\text { preventivos, educativos e sociais das principais doenças bucais, colocando o mais } \\
\text { precocemente possível, na prática e "in loco" com as condições reais de saúde bucal da infância } \\
\text { brasileira, estimulando, promovendo e valorizando o comportamento criativo, viabilizando o } \\
\text { conhecimento teórico associado a uma experiência local. }\end{array}$ & $\begin{array}{l}\text { Coleta do Índice de placa bacteriana; higiene bucal } \\
\text { supervisionada; classificação visual do risco de cárie; } \\
\text { aplicação tópica de flúor (moldeiras, escova e } \\
\text { bochechos); } \\
\text { levantamento epidemiológico; educação em saúde e } \\
\text { cidadania; } \\
\text { encaminhamento para tratamento na clínica da UNIT e } \\
\text { demais serviços do SUS. }\end{array}$ & $\begin{array}{l}\text { Duas Escolas } \\
\text { Públicas de Ensino } \\
\text { Fundamental } \\
\text { (E.E. do Bairro Jardim } \\
\text { das Palmeiras e } \\
\text { E.M. Olga De'l } \\
\text { Fávero) }\end{array}$ \\
\hline $\begin{array}{l}\text { Orientação } \\
\text { Profissional I/ } \\
\mathbf{4}^{\mathbf{0}} \text { Período }\end{array}$ & $\begin{array}{l}\text { Capacitar os alunos para que desenvolvam uma odontologia dentro dos princípios de } \\
\text { biossegurança, conhecer os equipamentos a serem utilizados para montagem dos consultórios, } \\
\text { de forma a diminuir os movimentos e o tempo no tratamento odontológico, identificar os riscos } \\
\text { ocupacionais e mostrar como preveni-los, viabilizando o conhecimento teórico associado a } \\
\text { prática da inserção da odontologia da Estratégia de Saúde da Família e aos primeiros contatos } \\
\text { com a clínica odontológica. }\end{array}$ & $\begin{array}{l}\text { Idem atividades do } 3^{\circ} \text { período, porém sendo } \\
\text { desenvolvidas junto as famílias de uma comunidade } \\
\text { socialmente excluída, no domicílio. }\end{array}$ & $\begin{array}{l}\text { Domicílios e } \\
\text { Equipamentos sociais }\end{array}$ \\
\hline $\begin{array}{l}\text { Orientação } \\
\text { Profissional II/ } \\
\mathbf{5}^{\circ} \text { Período }\end{array}$ & $\begin{array}{l}\text { Capacitar os alunos para que no contato com o paciente na Clínica Integrada tenha } \\
\text { oportunidade de realizar suas atividades, respeitando o ser humano que está lhe servindo de } \\
\text { instrumento de estudo dentro dos princípios da moral e da ética, viabilizando o conhecimento } \\
\text { teórico associado a uma experiência local. }\end{array}$ & $\begin{array}{l}\text { Idem atividades do } 3^{\circ} \text { período, porém sendo } \\
\text { desenvolvidas junto as crianças que freqüentam a creche. }\end{array}$ & $\begin{array}{l}\text { Creche Lar Alfredo } \\
\text { Júlio }\end{array}$ \\
\hline $\begin{array}{l}\text { Programa } \\
\text { Odontológico } \\
\text { Coletivo I e II/ } \\
\mathbf{7}^{\mathbf{0}} \mathbf{e ~}^{\mathbf{0}} \\
\text { Período } \\
\end{array}$ & $\begin{array}{l}\text { Executar as ações clínicas, restauradoras, cirúrgicas e de pronto atendimento, da comunidade } \\
\text { escolar que recebe atenção preventiva e educativa através dos alunos que cursam o } 2^{\circ} \text { período, } \\
\text { a partir do planejamento do risco individual de cárie, doença periodontal e tecidos moles, } \\
\text { promovendo a aplicação do princípio da integralização da atenção à saúde bucal. }\end{array}$ & $\begin{array}{l}\text { Atendimento clínico restaurador das crianças das escolas, } \\
\text { que recebem o Projeto durante o } 3^{\circ} \text { período do curso de } \\
\text { odontologia, conforme o risco. }\end{array}$ & $\begin{array}{l}\text { Clínica Odontológica } \\
\text { da UNIT }\end{array}$ \\
\hline
\end{tabular}




\subsubsection{ANEXO C}

\section{Unit

\section{CLASSIFICAÇÃO DAS FAMÍLIAS}

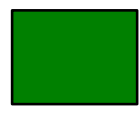

1. FAMÍLIA SEM RISCO:

- Famílias sem criança de até 5 anos de idade, sem gestante e sem patologia.

- Sem cárie, sem doença periodontal e não tem necessidade de prótese.

Ain

Visitas domiciliares uma vez a cada 2 meses, com possibilidade de visita na presença de evento sentinela ou de trabalhos grupais e ou comunitários.

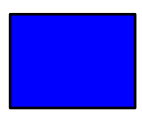

2. FAMÍLIA COM RISCO LEVE:

- Famílias com crianças de 1 a 5 anos de idade e ou gestante e ou adulto com patologia crônica controlada com tratamento.

- Um membro da família tem cárie ou doença periodontal ou necessita de prótese

Ẩ Visitas domiciliares uma vez por mês, com possibilidade de visita na prestação de evento sentinela ou de trabalhos grupais e ou comunitários.

\section{FAMÍLIA COM RISCO MODERADO:}

- Famílias com crianças menores de 1 ano de idade e ou gestante após o $7^{\circ}$ mês de gestação ou adulto com patologia crônica sem tratamento.

- Entre 1 a 3 membros da família tem cárie ou doença periodontal ou necessita de prótese

AิAี Visitas domiciliares de 3 em 3 semanas, com possibilidade de visitas quinzenais para gestante após o 8ำ mês de gestação.

\section{FAMÍLIA COM RISCO GRAVE:}

- Famílias com crianças menores de 1 ano que tenham fatores de risco como baixo peso ao nascer, desnutrição, prematuridade, malformações congênitas e ou com gestantes adolescentes e ou com adultos com doenças crônico degenarativas em presença de complicação e ou Doença Sexualmente Transmissível (DST) e ou com problemas sociais graves.

- Mais de três membros da família têm cárie ou doença periodontal ou necessita de prótese Visitas domiciliares quinzenais ou quando necessário de acordo com o trabalho desenvolvido pela equipe do PSF.

Observação: Procurando facilitar o trabalho da equipe do Programa de Saúde da Família e viabilizar o número e a freqüência de vistas, as famílias são classificadas em diferentes riscos de adoecer de acordo com a sua composição, por faixa etária, fatores de risco e eventos e ou marcadores.

Fonte: Classificação na área de saúde geral adaptada do Programa Família Saudável da Secretaria Municipal de Saúde de Uberlândia, 1999. 



\section{ANEXO D}

\section{DInTt PROGRAMA ODONTOIÓGICO COL ETIVO}

\section{SISTEMA ÚNICO DE SAÚDE - UBERLÂNDIA-MG}

\section{TRIAGEM PARA AVALIAÇÃO DO RISCO - PROCEDIMENTOS COLETIVOS}

ESCOLA ALUNO (s):
SÉRIE TURNO ANO/SEMESTRE

\begin{tabular}{|c|c|c|c|c|c|c|c|}
\hline \multicolumn{3}{|c|}{ "Baixo risco (1) } & \multicolumn{2}{|c|}{ "Risco moderado (2) } & \multicolumn{3}{|c|}{ Alto risco (3) } \\
\hline $\begin{array}{l}\text { A1: Ausência de lesão } \\
\text { de cárie, sem placa, sem } \\
\text { gengivite e sem mancha } \\
\text { branca ativa. }\end{array}$ & 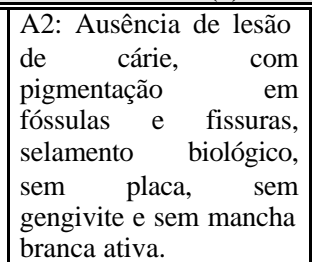 & $\begin{array}{l}\text { A3: Ausência de lesão } \\
\text { de cárie, com ou sem } \\
\text { pigmentação } r \text { em } \\
\text { fóssulas e fissuras, } \\
\text { selamento biológico, } \\
\text { com placa, sem } \\
\text { gengivite sem mancha } \\
\text { branca ativa }\end{array}$ & $\begin{array}{l}\text { B: história de dente } \\
\text { restaurado, sem placa, } \\
\text { sem gengivite e/ou sem } \\
\text { mancha branca ativa }\end{array}$ & $\begin{array}{l}\text { C: uma ou mais } \\
\text { cavidades em situação } \\
\text { de lesão de cárie } \\
\text { crônica, mas sem placa, } \\
\text { sem gengivite e/ou sem } \\
\text { mancha branca ativa }\end{array}$ & $\begin{array}{l}\text { D: ausência de lesão de } \\
\text { cárie ou presença de } \\
\text { dente restaurado, mas } \\
\text { com presença de placa, } \\
\text { de gengivite e/ou de } \\
\text { mancha branca ativa }\end{array}$ & \begin{tabular}{|lrr} 
E: uma ou mais \\
cavidades & em situação \\
de lesão de cárie aguda
\end{tabular} & $\begin{array}{l}\text { F: presença de dor } \\
\text { e/ou abscesso }\end{array}$ \\
\hline
\end{tabular}

\begin{tabular}{|c|c|c|c|c|c|c|c|c|c|c|c|c|c|c|}
\hline Nome & Idade & $\begin{array}{l}\begin{array}{c}\text { Ausência } \\
\text { de lesão }\end{array} \\
\end{array}$ & $\begin{array}{c}\text { Placa } \\
\text { visível } \\
\end{array}$ & Gengivite & $\begin{array}{l}\text { Presença de } \\
\text { cálculo } \\
\end{array}$ & $\begin{array}{l}\text { História de } \\
\text { cárie tratada } \\
\end{array}$ & $\begin{array}{c}\text { Mancha } \\
\text { branca ativa } \\
\end{array}$ & $\begin{array}{c}\begin{array}{c}\text { Cavidade } \\
\text { crônica }\end{array} \\
\end{array}$ & $\begin{array}{c}\text { Cavidade } \\
\text { aguda } \\
\end{array}$ & $\begin{array}{c}\text { Lesão } \\
\text { (+ de } 14 \text { dias) } \\
\end{array}$ & Fluorose & Urgência & $\begin{array}{l}\text { Classif } \\
(\mathrm{A}-\mathrm{F}) \\
\end{array}$ & $\begin{array}{l}\text { Risco } \\
(1,2,3) \\
\end{array}$ \\
\hline & & & & & & & & & & & & & & \\
\hline & & & & & & & & & & & & & & \\
\hline & & & & & & & & & & & & & & \\
\hline & & & & & & & & & & & & & & \\
\hline & & & & & & & & & & & & & & \\
\hline & & & & & & & & & & & & & & \\
\hline & & & & & & & & & & & & & & \\
\hline & & & & & & & & & & & & & & \\
\hline & & & & & & & & & & & & & & \\
\hline & & & & & & & & & & & & & & \\
\hline & & & & & & & & & & & & & & \\
\hline & & & & & & & & & & & & & & \\
\hline & & & & & & & & & & & & & & \\
\hline
\end{tabular}




\begin{tabular}{|c|c|c|c|c|c|c|c|c|c|c|c|c|c|c|}
\hline Nome & Idade & $\begin{array}{l}\text { Ausência } \\
\text { de lesão }\end{array}$ & $\begin{array}{c}\text { Placa } \\
\text { visível } \\
\end{array}$ & Gengivite & $\begin{array}{c}\text { Presença de } \\
\text { cálculo } \\
\end{array}$ & $\begin{array}{l}\text { Histsória de } \\
\text { cárie tratada } \\
\end{array}$ & $\begin{array}{c}\text { Mancha } \\
\text { branca ativa } \\
\end{array}$ & $\begin{array}{l}\begin{array}{c}\text { Cavidade } \\
\text { crônica }\end{array} \\
\end{array}$ & $\begin{array}{l}\begin{array}{c}\text { Cavidade } \\
\text { aguda }\end{array} \\
\end{array}$ & $\begin{array}{c}\text { Lesão } \\
\text { (+ de } 14 \text { dias }) \\
\end{array}$ & Fluorose & Urgênncia & $\begin{array}{l}\text { Classif } \\
\text { (A-F) }\end{array}$ & $\begin{array}{l}\text { Risco } \\
(1,2,3) \\
\end{array}$ \\
\hline & & & & & & & & & & & & & & \\
\hline & & & & & & & & & & & & & & \\
\hline & & & & & & & & & & & & & & \\
\hline & & & & & & & & & & & & & & \\
\hline & & & & & & & & & & & & & & \\
\hline & & & & & & & & & & & & & & \\
\hline & & & & & & & & & & & & & & \\
\hline & & & & & & & & & & & & & & \\
\hline & & & & & & & & & & & & & & \\
\hline & & & & & & & & & & & & & & \\
\hline & & & & & & & & & & & & & & \\
\hline & & & & & & & & & & & & & & \\
\hline & & & & & & & & & & & & & & \\
\hline & & & & & & & & & & & & & & \\
\hline & & & & & & & & & & & & & & \\
\hline & & & & & & & & & & & & & & \\
\hline & & & & & & & & & & & & & & \\
\hline & & & & & & & & & & & & & & \\
\hline & & & & & & & & & & & & & & \\
\hline & & & & & & & & & & & & & & \\
\hline & & & & & & & & & & & & & & \\
\hline & & & & & & & & & & & & & & \\
\hline
\end{tabular}

№ de crianças com baixo risco de cárie (1):

№ de crianças com risco moderado de cárie (2):

№ de crianças com alto risco de cárie (3):

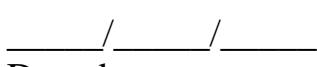

Data do exame assinatura dos aluno 


\section{ANEXO E}

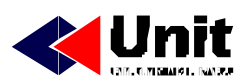

FORMULÁRIO DA INSTITUIÇÃO

\section{FICHA DE INSCRIÇÃO \\ PROCESSO SELETIVO}

As informações solicitadas neste questionário não influirão, de maneira alguma, no julgamento do candidato. Destinam-se, exclusivamente, as pesquisas de aspectos sócio culturais efetuadas pelo Centro Universitário do Triângulo - UNIT. Nestas pesquisas, os dados obtidos serão tratados estatisticamente, com vistas ao conhecimento do perfil do candidato. Não há respostas certas ou erradas, porém, as mesmas devem expressar a verdade. Agradecemos sua colaboração, pois as informações serão valiosas para nós.

01. Sexo:
(A) Masculino
(B) Feminino

02. Idade:
(A) menos de 20
(B) de 20 a 30
(C) mais de 30

03. Estado Civil:
(A) Solteiro
(B) Casado
(C) Outros

04. Número de filhos:
(A) 0
(B) 1-2
(C) 3-5

05. Local de Residência:
(A) Uberlândia
(B) Araguari
(C) Outros. Citar:

06. Qual é o nível de instrução de seu pai?
(A) Nenhum estudo
(E) Ensino Médio completo
(B) Ensino Fundamental incompleto
(F) Superior incompleto
(C) Ensino Fundamental Completo
(G) Superior completo
(D) Ensino Médio incompleto

07. Qual é o nível de instrução de sua mãe?
(A) Nenhum estudo
(E) Ensino Médio completo
(B) Ensino Fundamental incompleto
(F) Superior incompleto
(C) Ensino Fundamental Completo
(G) Superior completo
(D) Ensino Médio incompleto

08. Qual é a renda total de sua família?
(A) até 3 salários mínimos
(D) de 10 a 20 salários mínimos
(B) de 3 a 5 salários mínimo
(E) de 20 a 50 salários mínimo
(C) de 5 a 10 salários mínimos
(F) mais de 50 salários mínimos

09. Sua família reside em imóvel:
(A) próprio
(B) alugado

(C) outr Atualmente, você exerce atividade remunerada (trabalha)?
(A) não
(B) sim, em tempo parcial

(C) sim, em tempo integral

(D) sim, eventualmente

11. Se trabalha, assinale o tipo de atividade:
(A) comércio
(D) educação
(B) indústria
(E) outras atividades
(C) emprego público

12. Religião:
(A) católica
(B) cristã, não católica
(D) outra
(C) judaica
(E) sem religião, com fé em Deus
(F) nenhuma

13. Em que escola você concluiu ou concluiria o Ensino Médio $\left(2^{\circ}\right.$ grau
(A) particular
(C) municipal
(B) particular (com bolsa)
(D) estadual

Citar nome:

14. Que tipo de Ensino Médio ( $2^{\circ}$ grau), ou equivalente você concluiu ou concluirá?
(A) Formação Geral
(B) Curso Normal
(D) Curso Profissionalizante
(C) Curso Técnico
(E) Supletivo 
15. Você freqüenta ou freqüentou curso pré - vestibular (cursinho)?
(A) nenhuma vez
(C) duas vezes
(B) uma vez
(D) três vezes ou mais

16. Quanta vezes você prestou vestibular?
(A) nenhuma vez
(C) duas vezes
(B) uma vez
(D) três vezes ou mais

17. Você já iniciou algum curso superior?
(A) não
(C) sim, estou cursando
(B) sim, mas abandonei
(D) sim, já conclui

18. Se você abandonou ou pretende a bandonar o curso superior iniciado, qual foi o principal motivo desta decisão? Se não for este o seu caso, passe para a questão seguinte.
(A) porque não fui classificado no curso desejado
(C) porque me decepcionei com o curso
(B) porque não fui classificado na universidade
(D) porque mudei minha opção profissional desejada
(E) outros motivos

19. Como teve conhecimento do Processo Seletivo da UNIT?
(A) por alunos da UNIT
(B) por professores da UNIT
(C) por folhetos ou cartazes de divulgação
(D) por jornais

(E) por rádio

(F) pela televisão

(G) por out door/busdoor

(H) por outros meios. Citar:

20. Principalmente, o que você espera de um curso da UNIT?
(A) formação cultural ampla
(B) formação profissional voltada para o mercado
(C) formação científica voltada para a pesquisa
(D) outros de trabalho

21. Exceto livros escolares em média quantos livros você lê por ano?
(A) nenhum
(B) de 1 a 2
(C) de 3 a 5
(D) de 6 a 10
(E) mais de 10. Você lê jornal?
(A) não
(B) sim, ocasionalmente

(C) sim, aos domingos

(D) sim, diariamente

23. Você freqüenta algum tipo de curso extracurricular?
(A) sim, de língua estrangeira
(D) sim, de artes
(B) sim, de ginástica, dança ou esportes
(E) sim, outros
(C) sim, de música

24. Assinale abaixo qual o tipo de esporte que você pratica:
(A) esporte coletivo de campo
(E) esportes aquáticos
(B) esportes coletivos de quadra
(F) outras modalidades
(C) atletismo
(D) lutas olímpicas
(G) não prático esporte

25. Você possui ou manuseia computador?
(A) tenho e manuseio
(B) tenho, mas não manuseio
(C) não tenho e manuseio
(D) não tenho e não manuseio 


\section{ANEXO F}

\section{DIRIGIDO AOS ALUNOS DO CURSO DE ODONTOLOGIA}

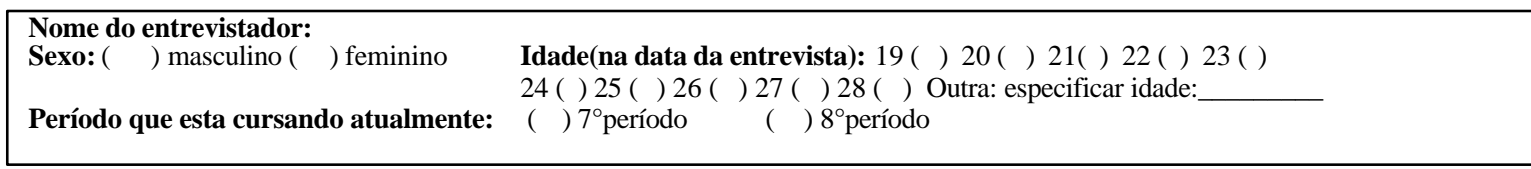

01. Por que você escolheu o curso de odontologia?

02. Quais são as contribuições de forma mais efetiva para sua formação, depois que você passou pelo Projeto Saúde Bucal Coletiva (denominado Saúde e Cidadania), desenvolvido durante $02^{\circ}$ ao $8^{\circ}$ períodos do curso de odontologia? (Em anexo, para relembrar o aluno, caso seja necessário, encontra-se a síntese das atividades desenvolvidas e o local das atividades práticas desenvolvidas em cada período)

\begin{tabular}{c|c}
\hline Período & Em caso de resposta afirmativa ou negativa, justifique sua resposta, para cada período. \\
\hline $2^{\circ}$ & \\
\hline $3^{\circ}$ & \\
\hline $4^{\circ}$ & \\
\hline $5^{\circ}$ & \\
\hline $7^{\circ}$ & \\
\hline $\begin{array}{c}\text { Não contribuiu } \\
\text { em nada }\end{array}$ & \\
\hline
\end{tabular}

03. Você deseja atuar, quando se formar, nesta área de abordagens coletivas em saúde bucal?

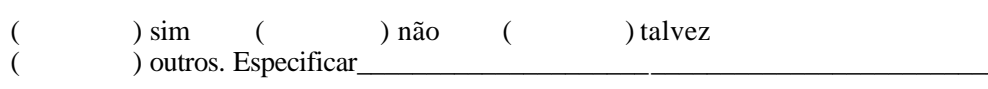

Justifique a sua resposta:

Qual a área de odontologia que você pretende atuar e por que?

04. Eleja um aspecto que você considera mais importante, dentre todas as atividades de ensino desenvolvidas durante o Projeto Saúde e Cidadania ( $2^{\circ}$ ao $8^{\circ}$ período)?

05. Existe alguma (s), dentre as atividades de ensino propostas pelo Projeto, que você considera que poderia (m) ser eliminada (s) ou modificada (s). Cite - a (as) e justifique sua resposta.

06. Em caso de atividade que necessita de modificação, qual é a proposta para alterá-la? 
07. Qual era sua expectativa frente às disciplinas de Saúde Bucal Coletiva (Projeto Saúde e Cidadania)? Você esperava desenvolver estas atividades práticas no curso de odontologia? Justifiquesua resposta.

08. Se as disciplinas, que envolvem o conteúdo da Saúde Bucal Coletiva $\left(\operatorname{do~}^{\circ}, 3^{\circ}, 4^{\circ}, 5^{\circ}, 7^{\circ}\right.$ e $8^{\circ}$ períodos $)$, fossem optativas, você as fariam? Justifique sua resposta.

09. O que você compreendeu sobre o Programa de Saúde da Família?

10. Como você avalia o Sistema Local de Saúde do município de Uberlândia?

11. Qual é o papel do odontólogo no Sistema Único de Saúde brasileiro?

12. Qual sua visão sobre as crianças que você atendeu?

13. Qual sua visão sobre as famílias que você atendeu?

14. Como era a saúde bucal das crianças e das famílias que você atendeu e por que?

Campo aberto para sugestões, críticas, dúvidas e observações. 


\section{ANEXO G}

\section{TERMO DE CONSENTIMENTO INFORMADO PARA OS ALUNOS DO CURSO DE ODONTOLOGIA}

Prezado Aluno

Estou desenvolvendo uma pesquisa intitulada: A Saúde Bucal Coletiva no Ensino de Odontologia: um estudo de caso. Este projeto de pesquisa tem como objetivo analisar a contribuição do Projeto Pedagógico em Saúde Bucal Coletiva - Saúde e Cidadania, na formação dos alunos do Curso de Odontologia.

Assim, gostaria de contar com sua participação nas respostas ao questionário, que será aplicado com os alunos que já participaram, no mínimo de duas etapas ou quatro períodos do projeto. O questionário será preenchido por uma auxiliar de pesquisa.

Sua colaboração será muito importante para a realização deste projeto de pesquisa. As informações/opiniões emitidas por você não causarão nenhum dano, risco ou ônus à sua pessoa e serão tratadas anonimamente no conjunto dos demais respondentes.

Ainda a qualquer momento da realização da pesquisa, caso não seja de seu interesse a continuidade na participação, haverá possibilidade de retirar esse consentimento.

Agradecendo sua colaboração me coloco à disposição para qualquer informação que você julgar necessária, e aguardo o mais prontamente possível sua confirmação quanto à participação nesta pesquisa para que possamos agendar data e local para o preenchimento do questionário.

Atenciosamente

\section{Prof ${ }^{a}$ Liliane Parreira Tannús Gontijo}

Mestranda do Programa de Enfermagem em Saúde Pública da USP/ Ribeirão Preto Profa. das Disciplinas de Odontologia Coletiva

Centro Universitário do Triângulo

Curso de Odontologia

Uberlândia - Minas Gerais
Prof ${ }^{a}$ Dra. Maria Cecília Puntel de Almeida Orientadora do Programa de Enfermagem em Saúde Pública da USP/ Ribeirão Preto

Eu, aceito participar do trabalho, respondendo ao questionário sobre o projeto de pesquisa A Saúde Bucal Coletiva no Ensino de Odontologia: um estudo de caso, em data e local marcado antecipadamente, e estou ciente de que seus resultados serão tratados sigilosamente, e caso não queira mais participar da investigação, tenho liberdade de retirar este consentimento.

de , de 2002. 


\section{ANEXO H}

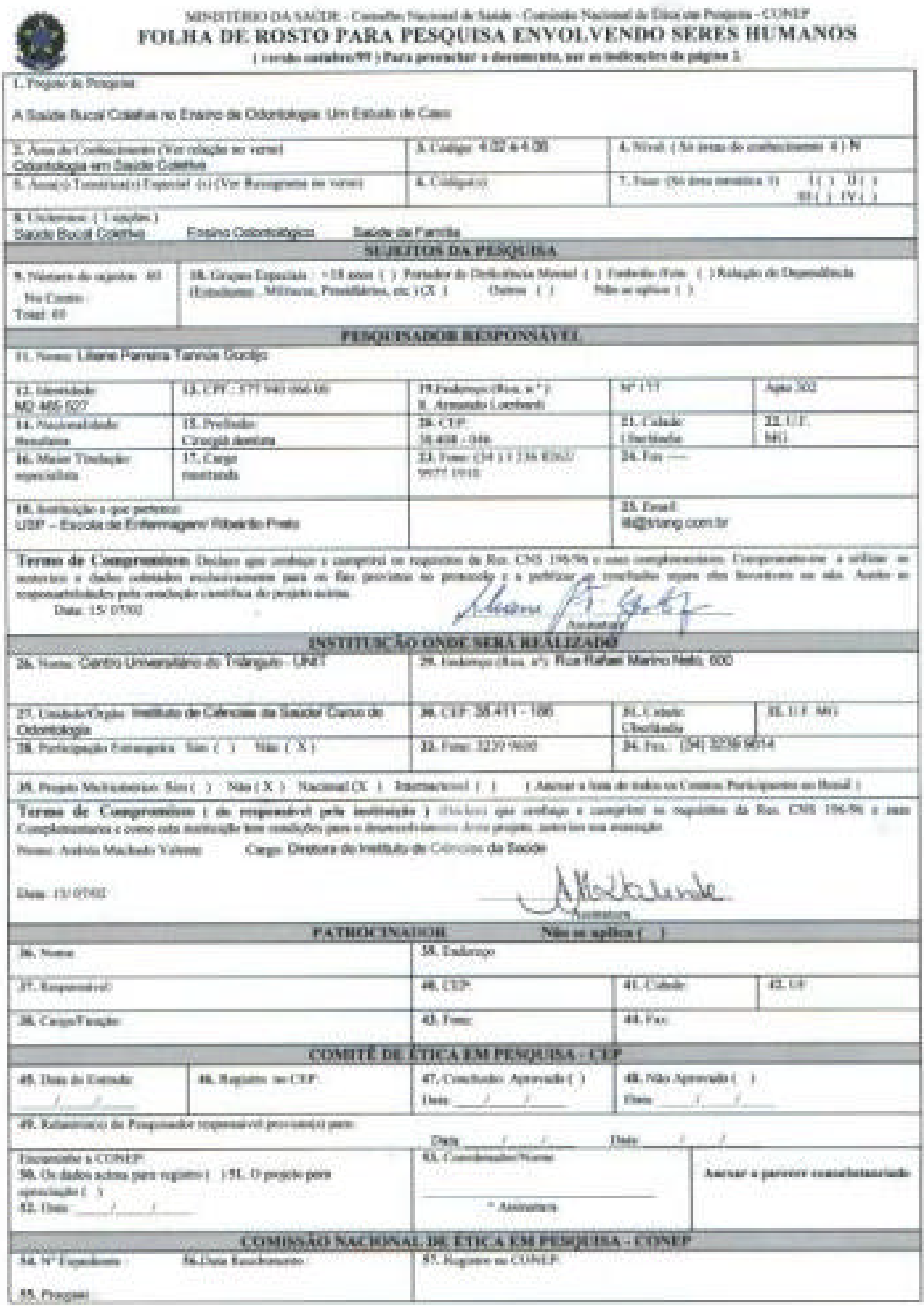




\section{- Familias do MG sãocadastradas}

A Secretaria Municipal de Saúde já está avaliando o cadastramento das familias do bairro Minas Gerais realizado pelos alunos do segundo período do Curso de Odontologia da Unit - Centro Universitário do Triângulo - e coordenado pelas professoras Leila Regina Scalia Gomide e Liliane Parreira Tannús Gontijo. 0 cadastramento foi realizado através do Projeto Saúde e Cidadania, no início de junho, através de visitas doniciliares, com o objetivo de promover a integração social do aluno e a comunidade sob a perspectiva da atenção primária em saúde e da humanizaçăo do ensino superior. Foi verificada a prioridade de atendimento odontológico, principalmente entre as crianças do bairro, que serão atendidas a partir da próxima segunda-feira, de 13 às 17 horas, na E. M. Prof. Saint Clair Neto. 


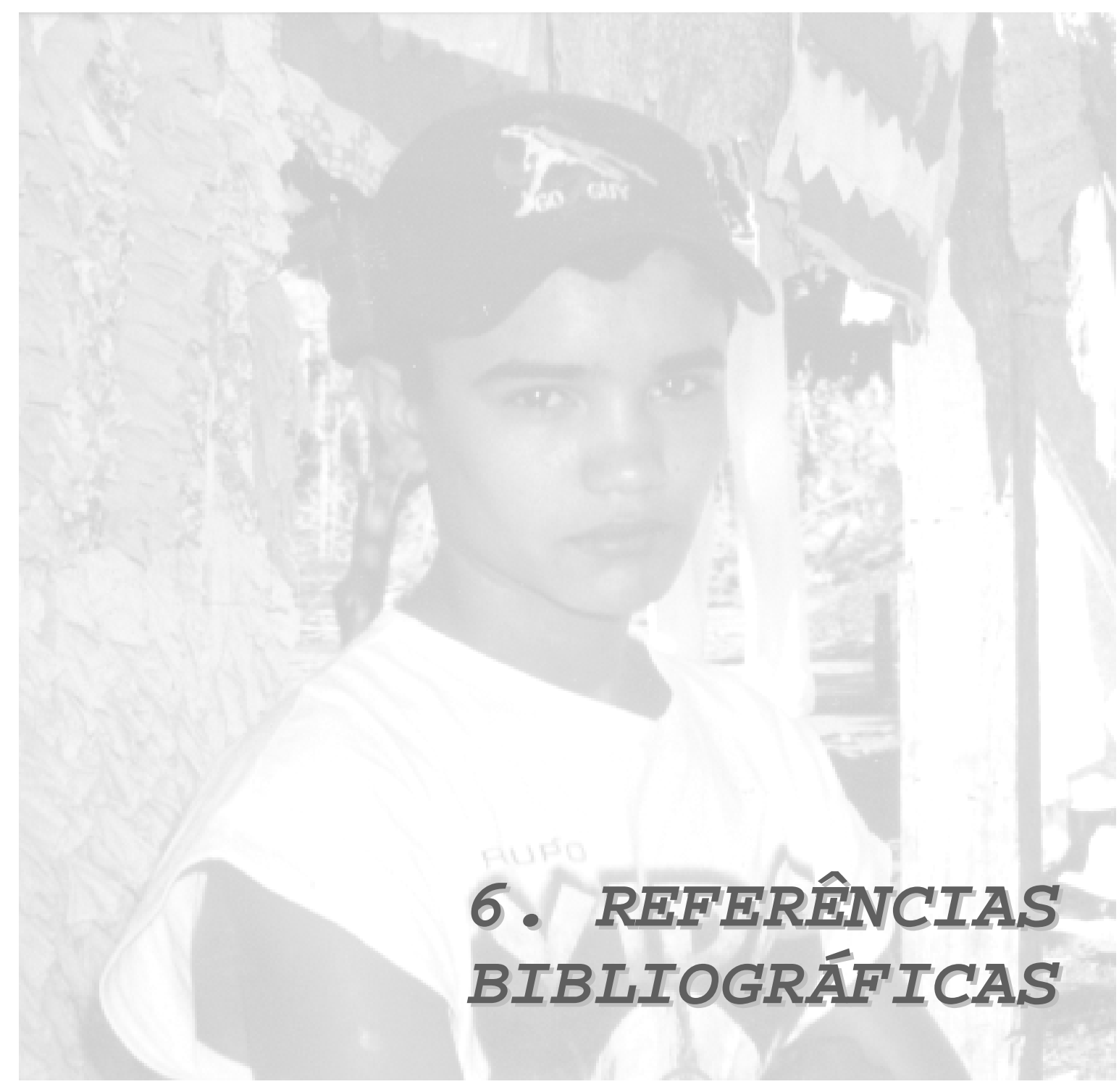


ADAMS, L.; PINTUS, S. A challenge to prevailing theory and pratice. Critical public health, 5: 17-29, 1994.

ALMEIDA, M. J. Educação Médica e Saúde: possibilidades de mudança. Rio de Janeiro: UEL, ABEM, 1999.

ALVES, R. A arte de produzir fome. Folha de São Paulo, São Paulo, 29 out. 2002, Sinapse, p. 6.

ASSIS, M. M. A. et al. O processo de gestão nas unidades básicas: limites e possibilidades de um novo agir em saúde. Saúde em Debate, Londrina, v. 52, p. 5866, 1996.

BEDFORD, W. O futuro da prevenção para grandes grupos populacionais. In: FÓRUM INTERNACIONAL DE SAÚDE BUCAL, ENCONTRO NACIONAL DE COORDENADORES DE OdONTOLOGIA, 4., Brasília. Painéis e conferências... Brasília: Secretaria Nacional de Programas Especiais, Divisão Nacional de Saúde Bucal, p. 22-25. 1989.

BOTAZZO, C.; FREITAS, S. (Org.).Ciências sociais e saúde bucal: questões e perspectivas. São Paulo: UNESP. 1998. 229 p.

BRANDÃO, C. R. O que é educação? 22. ed. São Paulo: Brasiliense SA, 1988. 116 p.

BRASIL. Ministério da Saúde. Portaria nº 1886, de 18 de dezembro de 1997. Aprova as normas e diretrizes do Programa de Agentes Comunitários de Saúde e do Programa de Saúde da Família. Diário Oficial da União, Brasília, DF, 1997.

Ministério da Saúde. CONASEMS. Legislação básica do SUS. Brasília, [199?]. $171 \mathrm{p}$. 
Ministério da Saúde. Portaria nº 1444, de 28 de dezembro de 2000. Cria o Incentivo de Saúde Bucal que garante financiamento as ações da equipe odontológica do Programa de Saúde da Família. Diário Oficial da União, Brasília, DF, 2000.

\begin{tabular}{lccccccccc} 
& \multicolumn{2}{c}{ Ministério } & da & Saúde. & Portaria & n. & 1.121, & de & 17 \\
de junho de & 2002. & Aprova & a & relação & dos & indicadores & a \\
serem $\quad$ pactuados & no & ano & de & 2002, & por & estados & e
\end{tabular}
municípios. Diário Oficial da União, Brasília, 18 jun. 2002. Disponível em: <http://www.saude.gov.br/pacto2002>. Acesso em: 5 ago. 2002.

BRUIJNE, P.; HERMAN, J.; SCHOUTHEETE, M. Dinâmica da pesquisa em ciências sociais. SP: Livraria Francisco Alves, 1991.

CHAVES, M.; KISIL, M. Origens, concepção e desenvolvimento. In: ALMEIDA, M.; FEUERWERKER, L.; LLANOS, C. M. (Org.). A educação dos profissionais de saúde na América Latina: teoria e prática de um movimento de mudança. São Paulo: Hucitec, 1999. v. 1, p. 1-16.

CRUZ, A. C. S.; SILVA, E. M. C. Motivos para escolha da carreira odontológica. Revista de Odontologia. São Paulo, v. 10, n. 4, p. 315-322. 1996.

DATASUS. Informações em Saúde. Disponível em: <www.datasus.gov.br>. Acesso em: 28 abr. 2000.

19,5\% da população nunca foi ao dentista. Folha de São Paulo, São Paulo, 19 jul. 2000. Cotidiano, C.5.

DOCUMENTO Final do seminário uni-odontologia Rionegro, Colômbia, 29/06 03/07/1998. Revista Brasileira de Odontologia em Saúde Coletiva, Brasília, p. 91 95, jul. 2000. Edição especial. 
EDUCAÇÃO à distância desponta no país. Folha de São Paulo, São Paulo, 9 maio 2002. FOVEST, p. 1-8.

EWLIS, L.; SIMNETT, I. Promoting health, a practical guide to health education. New York: John Wiley \& Sons, 1985.

FEUERWERKER, L.; COSTA, H.; BARBOSA, N.; KLALI:, M. E. O processo de construção e de trabalho da Rede UNIDA. Divulgação em Saúde para Debate. n. 22, p. 9-17, 10 dez. 2000.

FIGUEIREDO, J. F. de C. et al. Contribuição de diferentes atividades para o processo de aprendizagem, na percepção de alunos de medicina. Medicina, Ribeirão Preto. n. 29, p. 383-388, out./dez. 1996.

FREITAS, S. F. T. de; NAKAYAMA, M. Y. Um perfil do estudante de odontologia no Estado de São Paulo. Divulgação em Saúde para Debate, n. 10, p. 29-37, 1995.

GLASS, R. L. The of first international conference on the declining prevalence of dental caries. Journal of dental research 61 (Sp lss), 1982.

GOODE, W.; HATT, T. K. Métodos em pesquisa social. São Paulo, Nacional, 1960.

KING, L. S. The Flexner Report of 1910. JAMA, v. 251, p. 1079-1086, 1984.

LEVANTAMENTO epidemiológico. CFO Informa. Rio de Janeiro, mar.,1997. p. 3.

LUDKE, M.; ANDRÉ, M. E. D. A. Pesquisa em Educação: Abordagens Qualitativas. São Paulo: EPU, 1986.99p.

MACHADO, M. H. et al. O mercado de trabalho em saúde no Brasil: estrutura e conjuntura. Rio de Janeiro: ENSP, 1992. 94 p. 
MARSIGLIA, R. M. G. Relação ensino-serviços : 10 anos de Integração Docente Assistencial - IDA no Brasil. São Paulo: Hucitec, 1995.

MENDES, E.V. A evolução histórica da prática médica: suas implicações no ensino, na pesquisa e na tecnologia médicas. Belo Horizonte: PUC-MG/FINEP, 1984. $124 \mathrm{p}$.

MENDES, E. V.; MARCOS, B. Odontologia integral: bases teóricas e suas implicações no ensino e na pesquisa odontológicas. Belo Horizonte: PUCMG/FINEP, 1984. 66 p.

MENDONÇA, R. O paradoxo da miséria. Revista Veja, São Paulo, 23 jan. 2002. p. 82-93.

MILIO, N. Promoting health through public policy. Philadelphia: F. A. Davis, 1983.

MINISTÉRIO DA SAÚDE. Saúde Bucal-panorama internacional. Secretaria Nacional de Programas Especiais de Saúde. Brasília, Divisão Nacional de Saúde Bucal, 1990.

- Secretaria de Políticas de Saúde. Departamento de Atenção Básica. Disponível em: <saudebucalnobrasil.cjb.net>. Acesso em: 11 set. 2002.

MONTEZ CAMPUZANO, V. H. A odontologia latino-americana e seu impacto na solução dos problemas de saúde bucal da população. In: FÓRUM INTERNACIONAL DE SAÚDE BUCAL, ENCONTRO NACIONAL DE COORDENADORES DE ODONTOLOGIA, 4., Brasília. Painéis e conferências... Brasília: Secretaria Nacional de Programas Especiais, Divisão Nacional de Saúde Bucal, p. 39-42. 1989.

MURRAY, J. J. Comments on the conference. Second International Conference on Declining Caries. International Dental Journal. 44, p. 457-458, 1994. Supplement 1 . 
NADANOVSKY, P.; SHEIHAM, A. The relative contribution of dental service to the changes in caries levels of 12 years-old children in 18 industrialized countries in the 1970s and early 1980s. Community Dentistry oral epidemiology. 23, p. 331339, 1995.

NARVAI, P. C. Odontologia e saúde bucal coletiva. São Paulo: Hucitec, 1994. $113 p$.

Está ocorrendo um declínio de cárie no Brasil? ABOPREV. Rio de Janeiro, mar./abr., 1996. p. 12.

NOVAES, H. M. Ações Integradas nos Sistemas Locais de Saúde - SILOS: análise conceitual e apreciação de programas selecionados na América Latina. São Paulo: Pioneira, 1990.

NUNES, E. D. (Org.) As ciências sociais em saúde na América Latina. Tendências e perspectivas. Brasília: OPAS-OMS, 1985.

O BRASIL não é o campeão mundial de cárie. ABOPREV. Rio de Janeiro, mar./abr., 1996. p.1

PAIM, J. S.; ALMEIDA FILHO, N. A crise da saúde pública e a utopia da saúde coletiva. Salvador: Casa da Qualidade, 2000.123 p.

PAIXÃO, H. H.; CAMPOS, H.; LIMA, W. de A. O paciente como objeto de ensino. Arquivo Central Estatístico da Faculdade de Odontologia, UFMG, v. 18, n. 12, p. 37-44, jan./dez. 1981.

PINOTTI, J. A. Universidade e Saúde. In: A doença da saúde: por uma política de saúde no Brasil. Campinas: UNICAMP. 1984. cap. 7, p. 75-79. 
PINTO, V. G. Saúde bucal: panorama internacional. Brasília: Ministério da Saúde, Secretaria Nacional de Programas Especiais de Saúde, Divisão Nacional de Saúde Bucal. 1990. 285 p.

A odontologia no município. Porto Alegre: RGO. 1996. 253 p.

. Qual a nossa realidade epidemiológica? ABOPREV. Rio de Janeiro, maio/jun., 1997. p. 3.

Saúde bucal coletiva. 4. ed. São Paulo: Santos. 2000. 541 p.

POBRE perde dente antes dos 13 anos. Folha de São Paulo, São Paulo, 24 jul. 2000. Opinião.

PROJETO saúde e cidadania entusiasma alunos. Jornal UNIT, Uberlândia, p. 1-5, 31 ago. 2000.

REDE UNIDA. Contribuição da Rede UNIDA para as novas diretrizes curriculares dos cursos de graduação da área da saúde. Disponível em: <www.prouni.org/portugues/ frm_01apresent.htm>. Acesso em: 11 fev. 2000.

RENILSON, R. SUS: Quem é contra? Quem é a favor? Revista Diálogo Médico, São Paulo, p. 54-55, 2000.

RODRIGUES, N. Por uma nova escola: o transitório e o permanente na educação. 6 ed. São Paulo: Cortez, 1987. 120 p.

SALOMÃO, P. R. et al. O processo de conquista da gestão plena do sistema municipal de saúde - Uberlândia - MG. Saúde \& Cidade em Debate. Rio de Janeiro, p. 84-101, 1999. Número inaugural.

SÃO PAULO. Secretaria Estadual de Saúde. Coordenadoria de Planejamento em Saúde. Centro Técnico de Saúde Bucal. A organização das ações básicas de 
saúde bucal na atenção básica: uma proposta para o SUS de São Paulo. São Paulo, 2001. 39 p.(mimeo).

SILVA, R. C. da. A falsa dicotomia qualitativo-quantitativo: paradigmas que informam nossas práticas de pesquisas. In: ROMANELLI, G.; BIAZOLI-ALVES, Z.M.M. Diálogos Metodológicos sobre Prática de Pesquisa. Ribeirão Preto: Legis Summa Ltda, 1998. cap. 8, p. 159-174.

SILVEIRA, H. E .D. da; CORDÓN, J. A mulher no ensino superior em odontologia no Brasil. Revista Faculdade de Odontologia. Porto Alegre; 26 :25- 36, 1984. ilus, tab.

SPINELLI, P. S. Universidade e Sociedade. In: BOTAZZO, C.; FREITAS, S. F. T. de (Org.). Ciências Sociais e Saúde Bucal: Questões e Perspectivas. São Paulo: UNESP/EDUSC, 1998. cap.9, p.197-212.

TEIXEIRA, M. et al. Notas sobre a profissionalização da odontologia. In: MACHADO, M. H. Profissões de saúde: uma abordagem sociológica. Rio de Janeiro: FIOCRUZ, 1995. cap 12, p. 183-193.

TORRES, I. A. Câncer de Boca no Brasil - perfil atual do odontólogo frente ao problema. Revista Saúde em Debate, v. 37, p. 44-49, 1992.

UNESP. O país dos banguelas. Jornal da UNESP, n. 86, p. 8-10, 1994.

UNIT. Pró-Reitoria de Ensino e Graduação. Guia de Orientação Acadêmica do Professor. Uberlândia, 2000.

REUNIÃO ANUAL DE CIÊNCIA, 4., 2000, Uberlândia. Anais ... Uberlândia: Centro Universitário do Triângulo, 2000. 
VENTURELLI, J. Os aspectos educacionais na reforma da educação nas profissões da saúde. Miami: Fundação Kellogg, 1997. Seminário de Sistematização do Programa UNI - Relatório da Fundação Kellogg.

XAVIER, C. Cidade Saudável - uma filosofia e uma idéia. Tema. Rio de Janeiro, n. 19, p. 3-6, maio 2000.

WERNER, C. W. A. Formação de cirurgiões dentistas “um problema nacional”. Porto Alegre: ABOPREV, [1989?]. Resumo da tese submetida para obtenção do título de mestre em Saúde Pública pelo Departament of Community Dental Health and Dental Practice.

ZANETTI, C. H. G. A crise da odontologia brasileira: as mudanças estruturais do mercado de serviço e o esgotamento do modo de regulação curativo de massa. Ação Coletiva. Brasília, v. 2, n. 3, p. 11-24, jul./set., 1999. 


\title{
AUTORIZAÇÃO
}

Autorizo a reprodução e/ou divulgação total ou parcial da presente obra, por qualquer meio convencional ou eletrônico, desde que citada a fonte.

\section{Autor: Liliane Parreira Tannús Gontijo}

\author{
Assinatura do Autor: \\ Instituição: Universidade de São Paulo/Escola de \\ Enfermagem de Ribeirão Preto \\ Local: Ribeirão Preto - SP \\ Endereço: Avenida Bandeirantes, no 3900 - CEP: 14040 - 902 \\ E-mail: lili@triang.com.br
}

